\title{
Estudos moleculares em famílias com defeitos de membros
}

Dissertação apresentada ao Instituto de Biociências da Universidade de São Paulo, para obtenção de Título de Mestre em Ciências, na área de Biologia/Genética.

Orientadora: Profa. Dra. Regina Célia Mingroni Netto 
Ficha Catalográfica

\author{
Thiele-Aguiar, Renata Soares \\ Estudos moleculares em famílias com defeitos de \\ membros \\ 143.p \\ Dissertação (Mestrado) - Instituto de Biociências da \\ Universidade de São Paulo. Departamento de Genética e \\ Biologia Evolutiva. \\ 1. Mapeamento gênico \\ 2.Estudos de ligação \\ 3.Ectrodactilia \\ 4.Hemimelia tibial associada à ectrodactilia \\ 5.Aplasia Fibular
}

Comissão Julgadora:

$\operatorname{Prof(a).} \operatorname{Dr}(\mathbf{a})$.

$\operatorname{Prof}(a) . \operatorname{Dr}(\mathbf{a})$.

Profa. Dra. Regina Célia Mingroni Netto

Orientadora 
A minha família, àquela pessoa que um dia fará parte dela e a todos os amigos verdadeiros. 
"Demore na dúvida, e descubra a sabedoria que insiste em se esconder na ausência de palavras."

Padre Fábio de Melo 


\section{Agradecimentos}

Agradeço a minha orientadora Regina Célia Mingroni Netto pela orientação, apoio, confiança e paciência

À Dra Karina por toda a sua dedicação desde o início da minha vida laboratorial, me ensinando todas as técnicas e manejos com a maior paciência do mundo, pelas vindas de fim de semana para me ensinar os cálculos da vida, pela grande amizade que surgiu de tudo isso nas indas e vindas a noite no laboratório. Por toda a preocupação e predisposição em sempre me ajudar.

À Biomédica Maria Teresa Balester de Mello Auricchio, pelo auxílio técnico e sentimental em todos os momentos mais difíceis, sempre pronta para ajudar com aquele sorriso e abraços que são especiais e únicos da minha pequena.

Aos funcionários do Laboratório de Genética Humana, do Centro de Estudos do Genoma Humano, do Departamento de Genética e Biologia Evolutiva e do Instituto de Biociências da USP, em especial ao Paulo Rogério e a Maraísa que sempre me ajudaram muito com suas palavras de carinho e positivismo.

Aos meus colegas de laboratório Ana Carla, Daniel, Karina, Lilian, Daniela, Renata Nonose, Vitor, Claudia e Dayane. Agradeço em especial à Lilian pelo apoio científico e pelas aventuras que vivemos juntas, ensinamentos e grandes aprendizagens; à Ana Carla pelos conselhos sempre muito válidos e sábios, uma pessoa que sabe realmente viver a vida; aos meus dois grandes companheiros Daniela e Daniel que aos poucos conquistaram meu coração e hoje em dia são meus dois irmãos de consideração, amigos verdadeiros em que posso confiar, quantas noites no laboratório fazendo experimentos, rindo, chorando, reclamando, nos ajudando, 
navegando, imobilizando o diafragma, coisas inesquecíveis que ficarão pra sempre em meu coração. Obrigada por fazerem tudo ficar mais fácil, mais colorido e mais divertido.

Aos demais colegas do laboratórios vizinhos que sempre estiveram presentes para auxiliar e animar o ambiente de trabalho.

Aos pacientes e seus familiares, sem a qual esse trabalho não poderia ter sido realizado.

Ao Prof. Dr. Paulo Alberto Otto, do Departamento de Biologia do IBUSP, pela ajuda no cálculo das penetrâncias, pelos ensinamentos, pelas correções, pelas conversas e piadas e pelas ótimas idéias e sugestões.

À Profa. Dra. Angela Morgante, do Departamento de Biologia do IBUSP, pelas opiniões e sugestões valiosas.

À Profa. Dra Carla Rosenberg, do Departamento de Biologia do IBUSP, pela grande ajuda cientifica, idéias e sugestões valiosas.

À Dra Erika Freitas, que executou todos os experimentos de array-CGH para confirmação dos nossos resultados.

Ao Dr. Stefan Mundlos e a Dra. Eva Klopocki, do Instituto de Genética Médica da Universidade Charité e do Instituto Max Planck (Berlin-Alemanha, por me receberem tão bem no laboratório e aceitarem participar da pesquisa em colaboração com o nosso grupo, pelos ensinamentos, pelas sugestões que nos levaram a descoberta da mutação em uma das famílias presentes em meu estudo e pelos momentos agradáveis que me proporcionaram quando estava sozinha, em um país com língua e cultura diferentes e um pouco gelado demais.

Ao Dr. Bernt Wollnik, da Universidade de Colônia (Alemanha), que gentilmente nos doou alguns pares de primers para realizar os estudos de sequenciamentos de genes candidatos em duas famílias estudadas no mestrado. 
Ao meu grande companheiro, amigo e amor Gustavo, por sempre me incentivar, me apoiar, nunca me deixar desistir por mais que fosse difíceis as barreiras. Por estar disposto a fazer o nada virar tudo do jeitinho simples que só ele sabe resolver todos os problemas do mundo. Obrigada por sempre me dar forças, me encorajar e me ajudar em tudo que eu preciso.

Aos meus pais, em especial minha mãe que sempre acreditou que um dia eu conseguiria tudo aquilo que eu sonhei por isso sempre me incentivou e viveu de perto todas as minhas batalhas.

Aos meus irmãos Mauro e Márcio que sempre me apoiaram e tiveram orgulho de eu estar realizando esse projeto.

Aos meus avós Daisy e Tito que são peças e exemplos fundamentais na minha vida e que sempre me incentivaram a estudar e me apoiaram para eu chegar até aqui.

A todos os meus amigos que sempre escutavam eu falar do meu mestrado e interessados pergutavam sobre o que eu fazia, todos aqueles que compartilharam meus medos, minhas angustias, minhas ansiedades, minhas alegrias, meus resultados e que sempre estiveram do meu lado: Carla, Dri, Fê, Line, Fá, Mamá, Fabi, Tati, Van, Nauber, Ana entre tantos.

A todas as outras pessoas que passaram por minha vida e contribuíram de alguma forma para que eu realizasse esse projeto.

À Profa Dra. Mariana Zatz, coordenadora do Centro de Estudos do Genoma Humano, pela infraestrutura que permitiu a realização desse estudo.

Ao departamento de Genética e Biologia Evolutiva e o Instituto de Biociências da USP, pela infraestrutura.

Ao Depto. De Biologia do IBUSP, pelo uso das dependências. 
À FAPESP, pelo auxílio financeiro e pela bolsa de mestrado.

Ao CNPq, pelo auxílio financeiro. 


\section{Índice Geral}

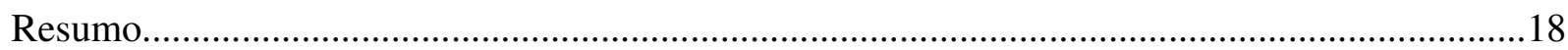

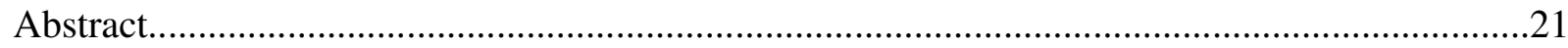

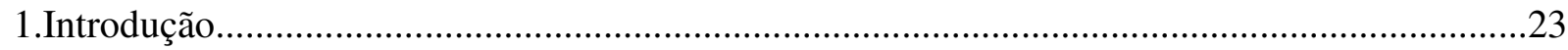

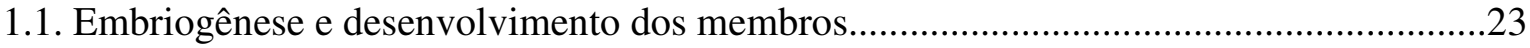

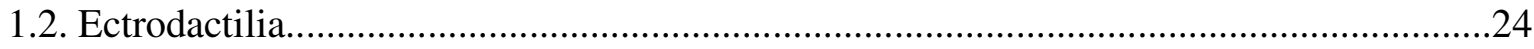

1.2.1.SHFM1

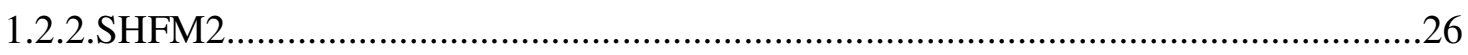

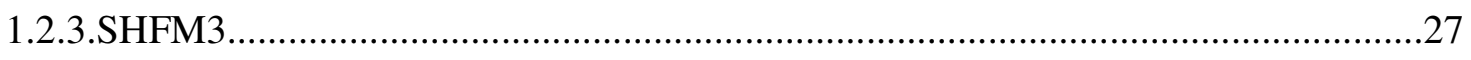

1.2.4.SHFM4

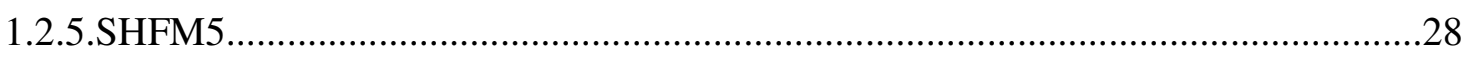

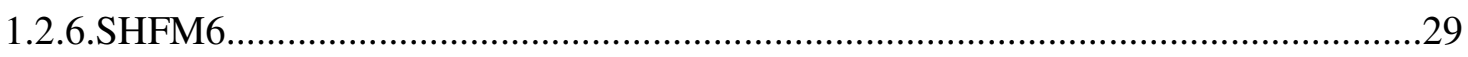

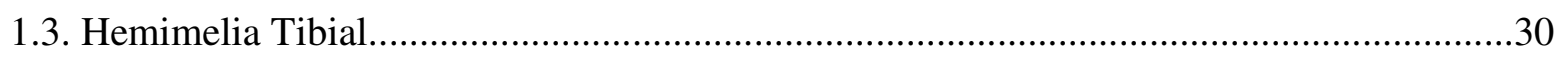

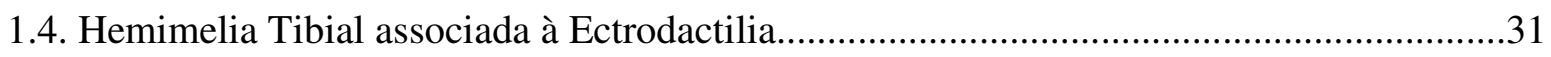

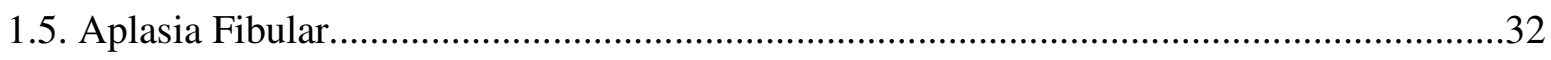

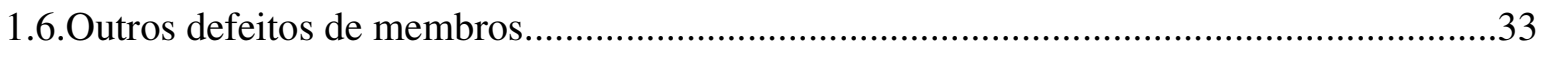

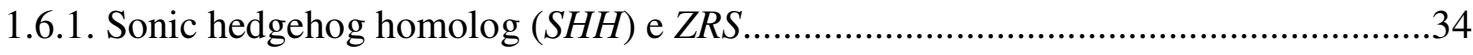

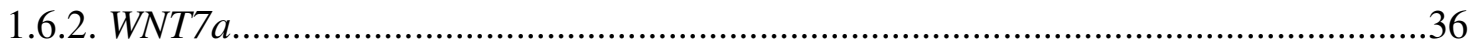

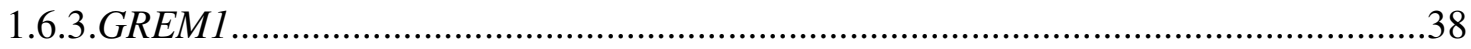

1.7. Estratégias de mapeamento de doenças genéticas..............................................................39

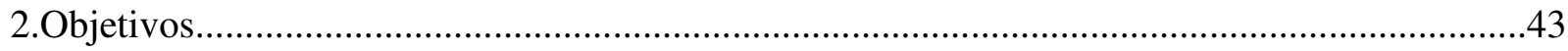

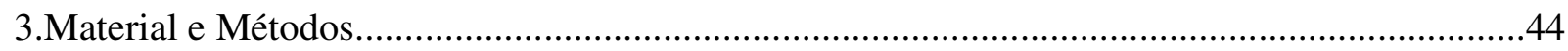

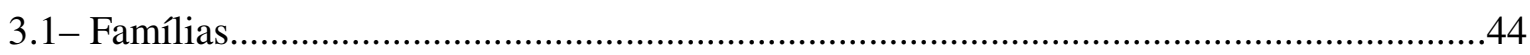

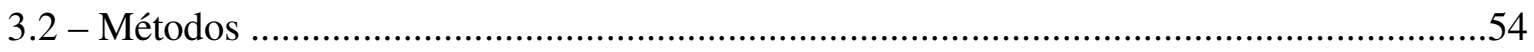




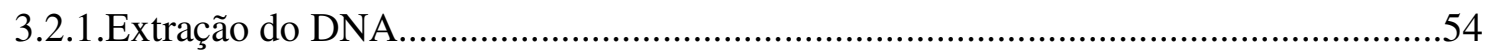

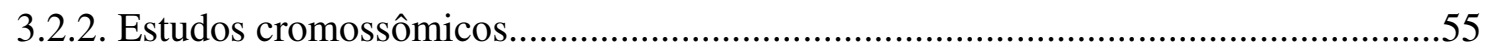

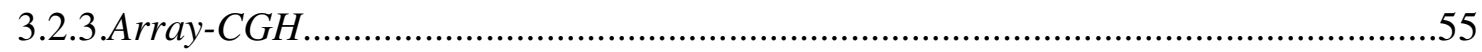

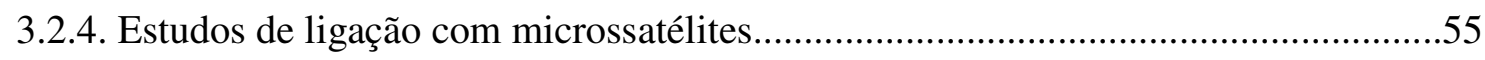

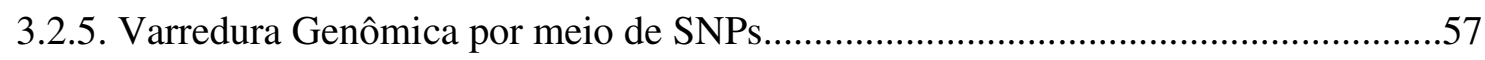

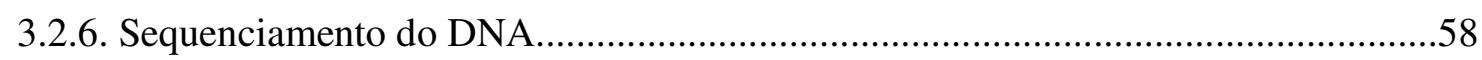

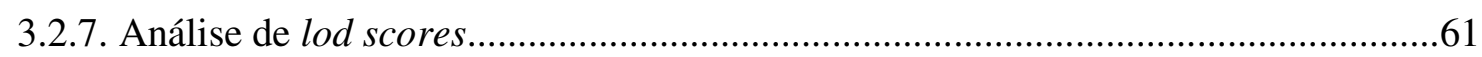

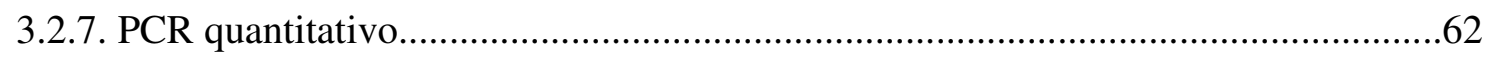

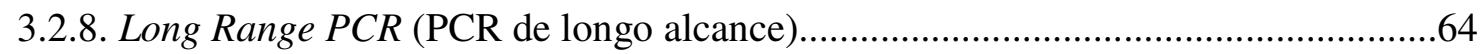

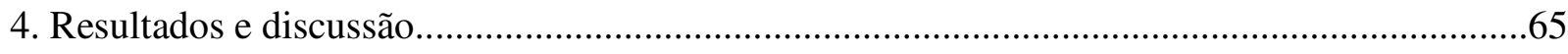

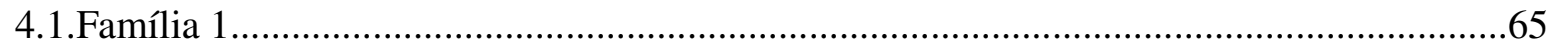

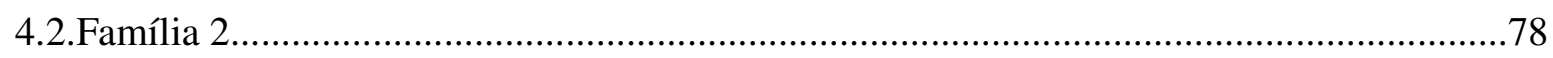

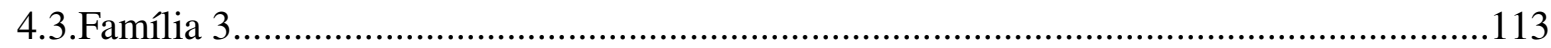

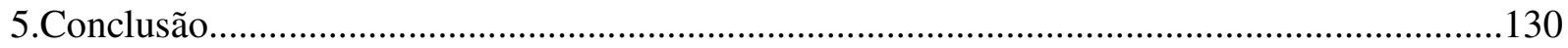

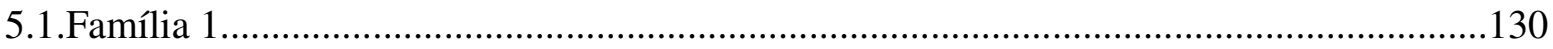

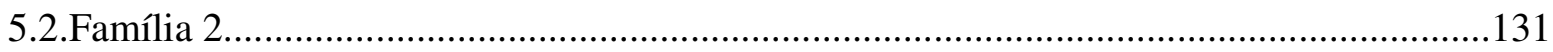

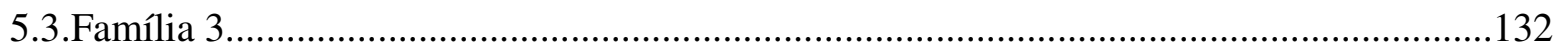

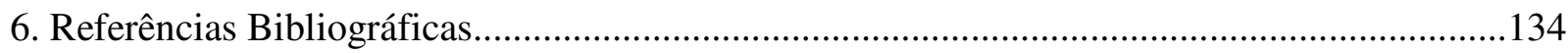




\section{Índice de Figuras}

Figura 1. Zona de polarização (ZPA) localizada próximo a junção posterior do membro jovem formado e perpendicular a crista ectodérmica apical (AER) Zeller e Zuniga., 2007).... (modificada de

Figura 2.Heredograma da família 1 mostrando os haplótipos do cromossomo 17. (B) Legenda do heredograma. (C) Mapa com as distâncias em cM e Kb entre os microssatélites analisados, onde se pôde definir a região cromossômica 17p13.3-17p13 como candidata (modificado de Lezirovitz e col., 2008).

Figura 3. Manifestações clínicas da família 1. (A) Paciente V:4 com sindactilia e camptodactilia; Raio-X da mão direita mostrando o defeito dos raios centrais da mão. (B) Paciente IV:7 com ectrodactilia à direita. (C) Paciente IV:10 com ectrodactilia (ausência do $3^{\circ}$ dígito) e raio-X correspondente. (D) Raio-X do paciente IV:26 com ectrodactilia. (E) Paciente V:6 com ectrodactilia em ambas as mãos. (F) Raio-X mostrando hemimelia tibial à direita no paciente IV:3 (modificado de Lezirovitz e col., 2008). .46

Figura 4. Heredograma da família 2. Os indivíduos assinalados em preto são afetados por um quadro clinico variável de malformações de mãos e pés, incluindo aplasia/hipoplasia fibular (modificado de Santos e col., 2008). .48

Figura 5. Indivíduos IV:31 e IV:20 com hipoplasia fibular e individuo V-12, com polidactilia à esquerda (modificado de Santos e col., 2008). . .48

Figura 6. Heredograma da família 3. Os indivíduos assinalados em preto são afetados por um quadro clínico muito variado de malformações de membros, incluindo polidactilia, sindactilia, e camptodactilia. .50

Figura 7. Foto do dorso das mãos da paciente II:16, após cirurgia corretiva. .51

Figura 8. Foto do dorso das mãos da paciente III:21 (A). Foto da lateral das mãos da paciente III:21 (B). 52

Figura 9. Foto do dorso das mãos do paciente III:23. (A). Foto dos pés do paciente III:21 (B). .53

Figura:10. Gráfico mostrando o resultado da PCR quantitativa nos indivíduos V:4 e IV:7 e a região duplicada. Cada barra representa um amplicon diferente e eles estão dispostos na 
ordem 5'-3', da esquerda para a direita. A última barra representa o segmento amplificado do gene $F 8$, presente no cromossomo X, que funciona como controle da reação. .68

Figura 11. Gráfico mostrando o resultado da PCR quantitativa nos indivíduos V:6, V:5, IV:7, III:3, IV:10, III:4 e IV:6. Cada barra representa um amplicon diferente e eles estão dispostos na ordem $5^{\prime}-3^{\prime}$, da esquerda para a direita. A última barra representa o segmento amplificado do gene $F 8$, presente no cromossomo $\mathrm{X}$, que funciona como controle da reação

Figura 12. Gráfico mostrando o resultado da PCR quantitativa nos indivíduos V:3, III:9, III:10, IV:20, IV:25 e IV:26. Cada barra representa um amplicon diferente e eles estão dispostos na ordem $5^{\prime}-3^{\prime}$, da esquerda para a direita. A última barra representa o segmento amplificado do gene $F 8$, presente no cromossomo $\mathrm{X}$, que funciona como controle da reação.. .70

Figura 13. Esquema representando a estratégia de mapeamento da duplicação. Os retângulos laranjas representam a localização das sondas do array-CGH. Os retângulos azuis representam os amplicons da primeira etapa de PCR quantitativo (10 pares de primers). Os retângulos amarelos representam os amplicons da segunda etapa do PCR quantitativo (17 pares de primers). As barras em verde representam as regiões consideradas certamente duplicadas por cada técnica; as linhas tracejadas representam as possíveis regiões duplicadas como mapeadas por cada técnica. .72

Figura 14. Gráfico mostrando o resultado da PCR quantitativa nos indivíduos IV:7 e IV:10. Cada barra representa um amplicon diferente e eles estão dispostos na ordem 5' -3', da esquerda para a direita. A primeira barra e a última barra representam o segmento amplificado do gene da $A L B$ e do gene $F 8$ que funcionam como controle da reação.. 73

Figura 15. Esquema representando a estratégia de estudo do ponto de quebra da duplicação .74

Figura 16. Reprodução de parte da sequência de referência da região 17p13.3 (Ensemble: 54: Maio 2009 - http://may2009.archive.ensembl.org/index.html) em comparação com a sequência do individuo afetado IV:7, mostrando o local exato do ponto de quebra proximal da duplicação, localizado no intron 4-5 do gene YWHAE (a sequência foi analisada no programa Sequencers). .74

Figura 17. Esquema mostrando a localização dos pontos de quebra distal e proximal na região $\quad 17 \mathrm{p} 13.3 \quad$ (Ensemble: $\quad$ 54: $\quad$ Maio 2009

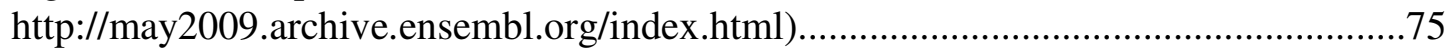

Figura 18. Heredograma da família 2 mostrando os haplótipos da região cromossômica 10q24.Os indivíduos assinalados em preto são afetados por um quadro clínico variado de malformações de mãos e pés, incluindo aplasia/hipoplasia fibular. 
Figura 19. Resultados de lod scores de múltiplos pontos obtidos com os marcadores da região 10q24, utilizando os dois modelos de herança autossômica.

Figura 20. Heredograma da família 2 mostrando os haplótipos da região cromossômica 17p13.3-17p13. Os indivíduos assinalados em preto são afetados um quadro clínico variado de malformações de mãos e pés, incluindo aplasia/hipoplasia fibular. .83

Figura 21. Heredograma da família 2 mostrando os haplótipos da região cromossômica 7q21.Os indivíduos assinalados em preto são afetados por um quadro clínico variado de malformações de mãos e pés, incluindo aplasia/hipoplasia fibular. 84

Figura 22. Heredograma da família 2 mostrando os haplótipos da região cromossômica 3q27. Os indivíduos assinalados em preto são afetados por um quadro clínico variado de malformações de mãos e pés, incluindo aplasia/hipoplasia fibular. .85

Figura 23.Heredograma da família 2 mostrando os haplótipos da região cromossômica 2q31. Os indivíduos assinalados em preto são afetados por um quadro clínico variado de malformações de mãos e pés, incluindo aplasia/hipoplasia fibular. 86

Figura 24. Resultados de lod scores de múltiplos pontos obtidos com os marcadores da região 17p13.3-17p13, utilizando os dois modelos de herança autossômica. .89

Figura 25. Resultados de lod scores de múltiplos pontos obtidos com os marcadores da região 7q21, utilizando os dois modelos de herança autossômica .90

Figura 26. Resultados de lod scores de múltiplos pontos obtidos com os marcadores da região 3q27, utilizando os dois modelos de herança autossômica. .90

Figura 27. Resultados de lod scores de múltiplos pontos obtidos com os marcadores da região 2q31, utilizando os dois modelos de herança autossômica. .91

Figura 28: Resultados dos lods scores de múltiplos pontos dos marcadores de cada autossomo calculados pelo programa Merlin. As linhas horizontais de coloração cinza claro em cada gráfico indicam os valores que se convencionaram para excluir ligação $(-2,00)$ e aceitar ligação $(+3,00)$ 92-99

Figura 29. Heredograma da família 2 mostrando os haplótipos da região 5p15.33. Os indivíduos assinalados em preto são afetados por um quadro clínico variado de malformações de mãos e pés, incluindo aplasia/hipoplasia fibular. 102

Figura 30. Heredograma da família 2 mostrando os haplótipos da região 6p25.3. Os indivíduos assinalados em preto são afetados por um quadro clínico variado de malformações de mãos e pés, incluindo aplasia/hipoplasia fibular. 
Figura 31. Heredograma da família 2 mostrando os haplótipos da região 10p15.3. Os indivíduos assinalados em preto são afetados por um quadro clínico variado de malformações de mãos e pés, incluindo aplasia/hipoplasia fibular.

104

Figura 32. Heredograma da família 2 mostrando os haplótipos da região 11p15.5. Os indivíduos assinalados em preto são afetados por um quadro clínico variado de malformações de mãos e pés, incluindo aplasia/hipoplasia fibular. 105

Figura 33. Heredograma da família 2 mostrando os haplótipos da região 13q12.11. Os indivíduos assinalados em preto são afetados por um quadro clínico variado de malformações de mãos e pés, incluindo aplasia/hipoplasia fibular. 106

Figura 34. Resultados de lod scores de múltiplos pontos obtidos com os marcadores da região 5p15.33, utilizando os dois modelos de herança autossômica. 110

Figura 35. Resultados de lod scores de múltiplos pontos obtidos com os marcadores da região $6 \mathrm{p} 25.3$, utilizando os dois modelos de herança autossômica. 110

Figura 36. Resultados de lod scores de múltiplos pontos obtidos com os marcadores da região 10p15.3, utilizando os dois modelos de herança autossômica. 111

Figura 37. Resultados de lod scores de múltiplos pontos obtidos com os marcadores da região estudada no cromossomo $11 \mathrm{p} 15$, utilizando o modelo de herança autossômica dominante. 111

Figura 38. Resultados de lod scores de múltiplos pontos obtidos com os marcadores da região estudada no cromossomo 13q12.11, utilizando os dois modelos de herança autossômica. 112

Figura 39.Heredograma da família 3 mostrando os haplótipos da região cromossômica 10q24. Os indivíduos assinalados em preto são afetados por um quadro variável de defeitos de membros entre eles polissindactilia, sindactilia, camptodactilia e defeitos ungueais. 115

Figura 40.Heredograma da família 3 mostrando os haplótipos da região cromossômica 17p13.3-17p13. Os indivíduos assinalados em preto são afetados por um quadro variável de defeitos de membros entre eles polissindactilia, sindactilia, camptodactilia e defeitos ungueais. 116

Figura 41.Heredograma da família 3 mostrando os haplótipos da região cromossômica 7q21. Os indivíduos assinalados em preto são afetados por um quadro variável de defeitos de membros entre eles polissindactilia, sindactilia, camptodactilia e defeitos ungueais 
Figura 42.Heredograma da família 3 mostrando os haplótipos da região cromossômica 3q27. Os indivíduos assinalados em preto são afetados por um quadro variável de defeitos de membros entre eles polissindactilia, sindactilia, camptodactilia e defeitos ungueais. 118

Figura 43.Heredograma da família 3 mostrando os haplótipos da região cromossômica 2q31. Os indivíduos assinalados em preto são afetados por um quadro variável de defeitos de membros entre eles polissindactilia, sindactilia, camptodactilia e defeitos ungueais. 119

Figura 44. Resultados de lod scores de múltiplos pontos obtidos com os marcadores da região $10 \mathrm{q} 24$.

Figura 45. Resultados de lod scores de múltiplos pontos obtidos com os marcadores da região $17 \mathrm{p} 13.3-17 \mathrm{p} 13$ 121

Figura 46. Resultados de lod scores de múltiplos pontos obtidos com os marcadores da região $7 \mathrm{q} 21$ 122

Figura 47. Resultados de lod scores de múltiplos pontos obtidos com os marcadores da região $3 q 27$. 122

Figura 48. Resultados de lod scores de múltiplos pontos obtidos com os marcadores da região $2 \mathrm{q} 31$ 122

Figura 49. Resultados dos lods scores de múltiplos pontos dos marcadores de cada autossomo calculados pelo programa Merlin. As linhas horizontais de coloração cinza claro em cada gráfico indicam os valores que se convencionaram para excluir ligação $(-2,00)$ e aceitar ligação $(+3,00)$ 124-127 


\section{Índice de Tabelas}

Tabela 1: Relação das regiões cromossômicas já associadas à ectrodactilia e respectivos genes candidatos (modificada de Duijf e col.,2003).

Tabela 2. Relação de alguns genes importantes na formação dos membros durante a embriogênese e suas respectivas localizações. .34

Tabela 3: Sequência dos primers utilizados para sequenciar genes candidatos. 59

Tabela 4: Primers utilizados para definir a duplicação encontrada no cromossomo $17 \mathrm{p} 13.3$ por PCR quantitativo na região distal da duplicação.

Tabela 5: Primers utilizados para definir a duplicação encontrada no cromossomo $17 \mathrm{p} 13.3$ por PCR quantitativo na região proximal da duplicação.

Tabela 6: Resumo dos resultados da PCR quantitativa .71

Tabela 7: Lod scores de dois pontos calculados com o programa MLINK do pacote FASTLINK em relação aos microssatélites da região cromossômica 10q24. O dois modelos de herança autossômica foram utilizados para a realização do calculo. (A) Herança autossômica dominante e (B) Herança autossômica recessiva. .81

Tabela 8: Lod scores de dois pontos calculados com o programa MLINK do pacote FASTLINK em relação aos microssatélites da região cromossômica 17p13.3-17p13. O dois modelos de herança autossômica foram utilizados para a realização do calculo. (A) Herança autossômica dominante e (B) Herança autossômica recessiva.

Tabela 9: Lod scores de dois pontos calculados com o programa MLINK do pacote FASTLINK em relação aos microssatélites da região cromossômica 7q21. O dois modelos de herança autossômica foram utilizados para a realização do calculo. (A) Herança autossômica dominante e (B) Herança autossômica recessiva.

Tabela 10: Lod scores de dois pontos calculados com o programa MLINK do pacote FASTLINK em relação aos microssatélites da região cromossômica 3q27. O dois modelos de herança autossômica foram utilizados para a realização do cálculo. (A) Herança autossômica dominante e (B) Herança autossômica recessiva. 88

Tabela 11: Lod scores de dois pontos calculados com o programa MLINK do pacote FASTLINK em relação aos microssatélites da região cromossômica 2q31. O dois modelos de herança 
autossômica foram utilizados para a realização do cálculo. (A) Herança autossômica dominante e (B) Herança autossômica recessiva.

Tabela 12: Lod scores de dois pontos calculados com o programa MLINK do pacote FASTLINK em relação aos microssatélites da região cromossômica 5p15.33. O dois modelos de herança autossômica foram utilizados para a realização do calculo. (A) Herança autossômica dominante e (B) Herança autossômica recessiva. 107

Tabela 13: Lod scores de dois pontos calculados com o programa MLINK do pacote FASTLINK em relação aos microssatélites da região cromossômica 6p25.3. O dois modelos de herança autossômica foram utilizados para a realização do calculo. (A) Herança autossômica dominante e (B) Herança autossômica recessiva. 107

Tabela 14: Lod scores de dois pontos calculados com o programa MLINK do pacote FASTLINK em relação aos microssatélites da região cromossômica 10p15.3. O dois modelos de herança autossômica foram utilizados para a realização do cálculo. (A) Herança autossômica dominante e (B) Herança autossômica recessiva. .108

Tabela 15: Lod scores de dois pontos calculados com o programa MLINK do pacote FASTLINK em relação aos microssatélites da região cromossômica $11 \mathrm{p} 15.5$. O dois modelos de herança autossômica foram utilizados para a realização do cálculo. (A) Herança autossômica dominante e (B) Herança autossômica recessiva.

Tabela 16: Lod scores de dois pontos calculados com o programa MLINK do pacote FASTLINK em relação aos microssatélites da região cromossômica 13q12.11. O dois modelos de herança autossômica foram utilizados para a realização do calculo. (A) Herança autossômica dominante e (B) Herança autossômica recessiva. 109-110

Tabela 17: Lod scores de dois pontos calculados com o programa MLINK do pacote FASTLINK em relação aos microssatélites da região cromossômica 10q24. 120

Tabela 18: Lod scores de dois pontos calculados com o programa MLINK do pacote FASTLINK em relação aos microssatélites da região cromossômica 17p13.3-17p13. 120

Tabela 19: Lod scores de dois pontos calculados com o programa MLINK do pacote FASTLINK em relação aos microssatélites da região cromossômica 7q21

Tabela 20: Lod scores de dois pontos calculados com o programa MLINK do pacote FASTLINK em relação aos microssatélites da região cromossômica $3 q 27$

Tabela 21: Lod scores de dois pontos calculados com o programa MLINK do pacote FASTLINK em relação aos microssatélites da região cromossômica $2 q 31$ 


\section{Resumo}

No presente trabalho foram desenvolvidos estudos genético-moleculares em três famílias com três síndromes distintas de defeitos dos membros.

A ectrodactilia ou SHFM (split-hand/split-foot malformation) é uma malformação congênita da extremidade dos membros caracterizada por fenda mediana profunda das mãos e/ou pés devido à ausência dos raios centrais. A hemimelia tibial é um defeito caracterizado por hipoplasia, aplasia ou agenesia de tíbia, em que a fíbula permanece intacta. A síndrome da hemimelia tibial associada à ectrodactilia é uma condição rara de herança dominante. Em uma publicação do nosso grupo foi mapeado um novo loco (SHFLD3 - OMIM \#612576) de hemimelia tibial associada à ectrodactilia (Lezirovitz e col. 2008. Am J Hum Genet 123:625-31) na região 17q13.1-17p13.3 em uma família com nove indivíduos afetados por essa síndrome. Nesse estudo foram sequenciados seis genes localizados na região candidata, mas nenhuma mutação patogênica foi encontrada. Em pesquisa colaborativa com grupo no exterior identificouse uma duplicação de cerca de $114 \mathrm{~Kb}$ nessa região cromossômica. Ela estava presente em todos os indivíduos afetados e por meio de PCR de longo alcance e seqüenciamento foi possível identificar os pontos de quebra da duplicação. Os resultados indicaram que essa é a provável causa da síndrome na família.

A agenesia/hipoplasia fibular é um defeito que ocorre ao longo do desenvolvimento e extensão da fíbula. Ela é encontrada isolada ou associada com outros sinais clínicos como malformações em membros superiores, como a ectrodactilia, e defeitos na ulna e fêmur. Em uma família em que segrega uma nova síndrome, uma forma de agenesia ou hipoplasia fibular associada à ectrodactilia de aparente herança autossômica dominante (Santos e col. 2008. Am J 
Med Genet A. 146A: 3126-31) foram realizados estudos de mapeamento por meio de marcadores de microssatélites e sequenciamento dos genes nas regiões candidatas. Após a exclusão de ligação com algumas regiões já conhecidas associadas a defeitos de membros, foram sequenciados alguns genes candidatos selecionados a partir da literatura sobre defeitos de membros (SHH, ZRS, WNT7a, WNT1Ob, GREM1). Dado que mutações não foram identificadas nesses genes, foi realizada a varredura genômica com o kit "Affymetrix GeneChip® Human Mapping 50K Array”. Foi observado que em quatro cromossomos (5, 6, 10 e 11) não foi possível a exclusão completa de ligação. Nesses cromossomos foram utilizados marcadores de microssatélites próximos às regiões que apresentaram lod score sugestivo de ligação. As análises dos cromossomos 6 e 10 não confirmaram evidências de ligação. No cromossomo 5 e no cromossomo 11 não foi possível a exclusão completa de ligação.

A terceira família é composta por três indivíduos afetados por um quadro variável de defeitos de membros, entre eles, polissindactilia, sindactilia, camptodactilia e defeitos ungueais. $O$ heredograma sugere um padrão de herança do defeito compatível com herança autossômica dominante e penetrância completa. Realizaram-se estudos preliminares de ligação com microssatélites próximos as regiões cromossômicas já conhecidas associadas a malformações de membros. Na região candidata 17p13.1-17p13.3 não foi possível a exclusão completa de ligação, já que os lod scores chegaram a mostrar valores positivos e sugestivos. Também foram sequenciados alguns genes candidatos (SHH, ZRS, WNT7a, WNT1Ob, GREM1). Dado que mutações não foram identificadas, foi realizada a varredura genômica com o kit “Affymetrix GeneChip ${ }^{\circledR}$ Human Mapping 50K Array”. A análise dos SNPs dos cromossomos 19, 20 e 21 permitiu a exclusão completa de ligação com esses cromossomos. Já em relação aos demais cromossomos, não se pode excluir completamente a ligação, já que vários deles 
apresentaram lod scores muito próximos do lod máximo possível calculado para a família. A dificuldade decorre do fato da família ser pequena e possuir somente duas gerações com indivíduos afetados. As regiões mais interessantes para aprofundar a investigação seriam as do cromossomo 17, pois houve sugestão de ligação também na análise de microssatélites. O gene YWHAE no cromossomo 17 foi sequenciado por se mostrar um bom candidato. No entanto, nenhuma mutação foi encontrada. 


\section{Abstract}

Here we report our genetic and molecular studies performed on three different families affected by three different syndromes with limb defects.

Ectrodactyly or SHFM (Split Hand/Foot Malformation) is a congenital limb malformation characterized by median cleft of hands or feet (absence of the central rays). Tibial Hemimelia is a malformation characterized by tibial hypoplasia, aplasia or agenesis without fibular involvement. Ectrodactyly associated with tibial hemimelia is a rare autosomal dominant condition. In a previous publication of our team, we reported the mapping of a novel locus (SHFLD3 - OMIM \#612576) for ectrodactyly associated with tibial hemimelia (Lezirovitz e col. 2008. Am J Hum Genet $123: 625-31$ ) to chromosome region $17 \mathrm{q} 13.1-17 \mathrm{p} 13.3$ in a large family with nine affected individuals. Six genes in the candidate region were sequenced, but no pathogenic mutation was found. In a collaborative study with another Center, a $114 \mathrm{~Kb}$ duplication, detected in all affected individuals, was found in this same region. Duplication breakpoints were identified after long range PCR and sequencing. Our results indicated indicating that this is the causative mutation in the family.

Fibular agenesis/hypoplasia is a fibular developmental defect, occurring either as an isolated defect or associated with other clinical signs, such as hand ectrodactyly, ulnar and femoral defects. Mapping studies with microsatellite markers were performed on a family with some affected individuals presenting fibular agenesis or fibular hypoplasia associated with ectrodactyly, a novel defect that segregates with a possible autosomal dominant mode of inheritance (Santos e col. 2008. Am J Med Genet A. 146A:3126-31). Linkage with markers mapped to some well known chromosome regions related with limb malformations was excluded. 
Some candidates genes possibly related to limb malformations were selected from the literature for sequencing (SHH, ZRS, WNT7a, WNT1Ob, GREM1). Since no mutation was found, we proceeded to genomic scanning with Affymetrix GeneChip Human Mapping 50k Array. Linkage with markers from four chromosomes $(5,6,10$ and 11) could not be completely excluded. Microsatellite markers were used to confirm linkage to regions presenting the higher lod scores and markers on chromosomes 6 and 10 did not confirm linkage. Analyses with markers on chromosomes 5 and 11 (in which there are no good candidate genes reported in the literature) were inconclusive and linkage could not be completely ruled out.

There are three affected individuals in the third family here reported, each one of them presenting with a different set of distal limb defects (such as syndactyly, polysyndactyly, camptodactyly, or nail malformation); the defect is transmitted with an autosomal dominant mode and complete penetrance. Linkage studies with microsatellite markers close to well-known limb malformation related regions were performed. Linkage with region $17 \mathrm{p} 13.1-17 \mathrm{p} .13 .3$ could not be ruled out since some of the lod scores were positive and suggestive. Some candidates genes have been selected for sequencing (SHH, ZRS, WNT7a, WNT1Ob, GREM1). Since no mutation was found, genomic scanning was performed with the Afflymetrix GeneChip Human Mapping 50k Array. SNP analysis of chromosomes 19, 20 and 21 allowed us to rule out linkage completely. However, linkage could not be excluded for some regions on other chromosomes, since their lod scores were close to the maximum possible score estimated for this small-sized family. The most interesting regions are located in chromosome 17, in which the gene $Y W H A E$, which seemed to be a good candidate, was sequenced, but no mutation was found. 


\section{Introdução}

\subsection{Embriogênese e desenvolvimento dos membros}

Ao redor do $33^{\circ}$ após a fecundação, os embriões de mamíferos iniciam o desenvolvimento de membros por meio do crescimento de pequenos núcleos indiferenciados de células mesenquimais recobertas pela ectoderme. Esses pequenos brotos de células aparecem em locais específicos ao longo do eixo cabeça-cauda, paralelamente ao plano mediano (Duijf e col.,2003). Durante esse desenvolvimento, ocorre o achatamento das células mesenquimais, induzindo o espessamento da ectoderme que as recobre, e formando a crista ectodérmica apical (AER). Durante essa etapa, a sinalização posicional adequada entre as células mesenquimais e a AER dentro da estrutura tridimensional do membro é crucial para a diferenciação celular. Diversos genes que participam dessas vias de sinalização já foram identificados, como por exemplo, FGF4, FGF8, SHH, WNT7a, BMP2, BMP4, entre outros (Niswander, 2003).

Por volta do $38^{\circ}$ dia os raios digitais já são visíveis sob a forma de espirais, com as pontas dos futuros dígitos projetando-se em direção à extremidade dos pequenos brotos. No $41^{\circ}$ dia os raios digitais são estabilizados e ocorre a inervação do futuro membro pelos nervos radiais,

mediano e ulnar. É também durante esse período que as regiões interdigitais são formadas como resultado da apoptose de células pré-definidas anteriormente. No final na $8^{\circ}$ semana de gestação, interações entre produtos de diversos genes e demais moléculas de sinalização dão origem à completa diferenciação dos membros, que terão uma aparência e função bem definidas e um número especifico de dígitos (Niswander, 2003).

Malformações congênitas de membros ocorrem como defeitos isolados de mãos e pés ou como parte de síndromes. Uma das causas mais comuns desses defeitos são perturbações nas 
principais vias de sinalização relacionadas ao desenvolvimento de membros (Niswander, 2003).

\subsection{Ectrodactilia}

A forma clássica de ectrodactilia, também conhecida como SHFM (split-hand/split-foot malformation), é uma malformação congênita de membros caracterizada por fendas medianas profundas nas mãos e/ou pés com ausência de dígitos, devido a um defeito no desenvolvimento dos raios centrais (Crackower e col., 1996). A prevalência do defeito foi estimada entre 1/10000 e 1/90000 nascimentos na população em geral (Tentamy \& McKusick, 1978 e Nelson e Holmes, 1980 apud Nunes e col.,1995)

A expressividade da SHFM é muito variável entre indivíduos afetados de famílias diferentes ou da mesma família e entre os membros homólogos de um mesmo individuo, podendo exteriorizar-se como sindactilia (fusão de dois ou mais dígitos), aplasia e/ou hipoplasia de falanges, metacarpos e metatarso em casos mais leves ou apresentar-se com uma aparência característica de garras de lagosta, monodactilia ou até mesmo ocorrer ausência completa do autópode (Evermam e col., 2006).

A SHFM é clinicamente muito heterogênea e pode se apresentar de forma isolada ou sindrômica. A forma isolada (não-sindrômica) pode ocorrer ou associada ou não a outras deficiências de ossos longos (Mollerat e col., 2003). Já a ectrodactilia sindrômica está associada a defeitos em outros sistemas incluindo malformações craniofaciais, genitais e urinárias e de estruturas ectodérmicas (Crackower e col., 1996). Dentre as várias síndromes com SHFM, a mais comum é conhecida como ECC (ectrodactilia, displasia ectodérmica e fissura lábio-palatalOMIM \#129900). 
A ectrodactilia não-sindrômica geralmente tem o padrão de herança autossômico dominante com penetrância incompleta da ordem de 90\% (Zlotogora, 1994). São descritos também casos raros de herança ligada ao cromossomo $\mathrm{X}$ ou herança autossômica recessiva (Everman, 2006). Existem também casos de SHFM que são causados por deleções ou duplicações em regiões cromossômicas.

O mapeamento de genes responsáveis pela SHFM foi possível detalhando-se o estudo de defeitos cromossômicos em afetados por ectrodactilia e por meio de estudos de ligação com marcadores moleculares realizados em famílias com um grande número de indivíduos afetados. Foram identificados seis locos (ou regiões candidatas) a conter genes responsáveis por ectrodactilia, como mostra a tabela 1 .

Tabela 1: Relação das regiões cromossômicas já associadas à ectrodactilia e respectivos genes candidatos (modificada de Duijf e col.,2003).

\begin{tabular}{|l|c|c|}
\hline $\begin{array}{c}\text { Regiões cromossômicas } \\
\text { candidatas }\end{array}$ & $\begin{array}{c}\text { Localização } \\
\text { cromossômica }\end{array}$ & Genes Candidatos \\
\hline SHFM1 (OMIM \#183600) & $7 \mathrm{q} 21$ & DLX5, DLX6 e DSS1 \\
\hline SHFM2 (OMIM \#313350) & Xq26 & FGF13 e TONDU \\
\hline SHFM3 (OMIM \#600095) & $10 \mathrm{q} 24$ & DACTYLIN, SUFU e $B T R C$ \\
\hline SHFM4 (OMIM \#605289) & $3 \mathrm{q} 27$ & DLX1 e $D L X 2$ \\
\hline SHFM5 (OMIM \#606708) & $2 \mathrm{q} 31$ & $W N T 10 b$ \\
\hline SHFM6 (OMIM \#225300) & $12 \mathrm{q} 13$ & \\
\hline
\end{tabular}




\subsubsection{SHFM1}

Um grande número de casos isolados de SHFM ou formas sindrômicas de ectrodactilia está associado a aberrações cromossômicas abrangendo a região 7q21.3-q22. Famílias com SHFM e deficiência auditiva sensorioneural sempre mostram ligação com esse loco. Extensivas análises comparativas de deleções nessa região permitiram selecionar uma região cromossômica critica de 1.5 Mb. Três genes em comum foram localizados nesses intervalos de deleção: $D L X 5$, DLX6 e DSS1 (Duijf e col., 2003). Em teoria, qualquer um desses três genes é candidato a explicar a ectrodactilia nesses casos de alteração cromossômica. No entanto, até o momento, não há descrição na literatura de famílias com muitos indivíduos afetados por ectrodactilia nãosindrômica, cujos estudos de ligação tenham apontado o loco SHFM1 em 7q21.3-q22 como candidato a conter o gene responsável pelo defeito.

\subsubsection{SHFM2}

Apenas uma única família paquistanesa com SHFM (ectrodactilia não-sindrômica) foi descrita na literatura por Ahmad e col, (1987) com um padrão de herança do defeito compatível com herança ligada ao cromossomo X. Os pacientes dessa família paquistanesa exibiam malformação típica com aspecto de garras de lagostas, monodactilia e pés fendidos. A família era composta de 36 indivíduos afetados no qual 33 eram homens e 3 mulheres. A hipótese de herança ligada ao cromossomo X levou a um extensivo detalhamento dos sinais clínicos das mulheres heterozigotas que apresentavam uma expressão mais leve e branda do fenótipo (Duijf e col., 2003). 
Por meio de estudos de ligação foi possível mapear o loco SHFM2 na região cromossômica Xq26. Possíveis genes candidatos nessa região incluem FGF13 e TONDU, mas ainda não foram encontradas mutações que confirmem essa hipótese (Duijf e col., 2003).

\subsubsection{SHFM3}

O terceiro loco associado à SHFM não-sindrômica foi definido como uma região de cerca de 2cM, localizada em 10q24-q25, que contém vários genes que podem estar relacionados ao inicio do desenvolvimento embrionário dos membros, um dos quais é o gene da dactilina (DACTYLIN).

Já foi identificada uma duplicação de aproximadamente $0,5 \mathrm{Mb}$ que continha cópias dos genes $L B X 1$ e $\beta T R C$ e uma cópia parcial do gene DACTYLIN em seis pacientes com ectrodactilia de seis diferentes famílias cujo fenótipo mostrou ligação ao SHFM3 (Mollerat e col., 2003). Duplicações genômicas semelhantes em tandem também já foram encontradas em duas famílias japonesas com SHFM não-sindrômica (Kano e col., 2005) e em oito de 44 casos de SHFM sindrômica e não sindrômica estudadas por Everman e col. (2006). Esses achados totalizam em 16 o número de rearranjos cromossômicos semelhantes que envolvem o gene DACTYLIN presente nessa região. Existe ainda um grande número de genes candidatos localizados na região cromossômica 10q24 como, por exemplo, $F G F 8$, SUFU e BTRC, mas nenhuma mutação nesses genes que confirme essas hipóteses foi encontrada (Duijf e col., 2003).

Expansões ou contrações de repetições de trinucleotídeos CGG no gene HOX11 localizado nessa região também poderiam explicar a antecipação visualizada em famílias com SHFM3, mas isso nunca foi confirmado. 


\subsubsection{SHFM4}

A região cromossômica $3 q 27$ foi o primeiro loco associado à SHFM que teve um gene e uma mutação precisamente identificados como responsáveis pela ectrodactilia. Mutações associadas a SHFM4 foram encontradas no gene TP63. O gene TP63 codifica uma proteína homóloga a proteína supressora de tumor p53 e tem um papel importantíssimo no desenvolvimento embrionário.

Mutações no gene TP63 foram primeiramente identificadas em pacientes com ECC (ectrodactilia, displasia ectodérmica e fissura lábio-palatal). Mais tarde, mutações nesse gene foram descritas em casos de ectrodactilia não-sindrômica e em um grande número de outras síndromes (como a síndrome membro-mamária). No total, foram encontradas e descritas sete mutações no gene TP63 em famílias afetadas por ectrodactilia não-sindrômica ou em pacientes isolados (Duijf e col., 2003).

\subsubsection{SHFM5}

Pacientes com deleções na região cromossômica 2q24-q31 exibem uma série de anormalidades incluindo microcefalia, retardo mental, micrognatia e malformações de membros. Apenas um número pequeno de pacientes apresentaram deleções nessa região associada com a ectrodactilia típica. Por meio de uma análise extensiva de deleções nessa região, foi possível determinar um intervalo critico relacionado a SHFM5, situado entre os genes que constituem o agrupamento HODX localizado em 2q31.1, entre o gene EVX2 e o microssatélite D2S294 (Duijf e col., 2003). Genes candidatos localizados na região critica do intervalo de SHFM5 incluem o DLX1 e $D L X 2$, dois genes que possuem domínios homeobox e que são expressos na AER e na zona de progresso (agrupamento de células importantes no inicio do desenvolvimento 
embrionário dos membros). Nenhuma mutação nesses genes levando à ectrodactilia foi encontrada.

\subsubsection{SHFM6}

A região cromossômica 12q13.11-q13 foi o segundo loco associado a SHFM que teve um gene e uma mutação precisamente identificados como responsáveis pela ectrodactilia. A primeira mutação associada foi encontrada em uma família da Túrquia Oriental constituída por 13 afetados por SHFM autossômica recessiva. Todos os indivíduos afetados nasceram de casamentos consanguíneos. Doze dos afetados apresentaram uma redução central nos ossos dos pés acompanhada ou não do comprometimento das mãos e um único afetado apresentou um quadro atípico à SHFM, tendo apenas a mão com sindactilia unilateral, sem envolvimento dos pés. Em geral, as mulheres foram menos gravemente afetadas que os homens, sendo que as mãos foram muito menos afetadas do que os pés. A característica apresentou expressividade muito variável entre os indivíduos afetados (Ugur e Tolun .,2008).

Por meio de estudos de ligação com microssatélites foi identificada uma região candidata em 12q13.11-q13 com lod de múltiplos pontos atingindo 5,47. Nessa região foi sequenciado o gene WNT10B, importante gene relacionado à sinalização durante a formação de membros na embriogênese. Encontrou-se uma mutação de sentido errado em homozigose em todos os indivíduos afetados. Este é o primeiro estudo sobre o papel do gene WNT1OB no desenvolvimento dos membros, sendo a primeira mutação encontrada. O gene $W N T 10 b$ age como uma chave de sinalização, promovendo a osteoblastogênese e inibindo a formação de células adiposas (Ugur e Tolun .,2008). 
Estudos recentes descreveram pacientes, casos esporádicos com SHFM, que possuíam uma mesma duplicação de 4bp no gene WNT10b. Essa mutação levava a um códon prematuro de parada e foi identificada como a possível responsável pelo fenótipo (Blattner e col., 2010).

\subsection{Hemimelia Tibial}

A hemimelia tibial é uma anomalia rara e geneticamente heterogênea. É caracterizada por deficiência da tíbia ou ausência da tíbia, com a fíbula permanecendo relativamente intacta. Ela pode ser classificada em quatro tipos de acordo com critérios radiológicos (Matsuyama e col., 2003).

O defeito da tíbia é muito variável podendo ocorrer desde ausência completa até ausência distal ou proximal. Ela pode se apresentar como uma anomalia isolada ou estar associada com outras malformações esqueléticas ou extraesqueléticas.

$\mathrm{Na}$ maioria dos casos, a hemimelia tibial costuma ocorrer em casos isolados. Entretanto, famílias com vários indivíduos afetados já foram descritas na literatura. Em grande parte dos casos familiais a doença se apresenta com um padrão de herança autossômico dominante, demonstrando grande variabilidade clínica e penetrância reduzida.

Já foram sugeridos três genes como possíveis responsáveis pela doença, uma vez que suas funções estão relacionadas ao desenvolvimento de membros durante a embriogênese: $H O X D-11$ (região cromossômica 2q31.1), HOXD-12 (região cromossômica 2q31-q32) e o $S H H$ (região cromossômica 7q35-7qter), mas até o momento nenhuma mutação foi encontrada para sustentar tal hipótese (Matsuyama e col., 2003). 


\subsection{Hemimelia Tibial associada à Ectrodactilia}

Segundo Richieri-Costa e col. (1987a) a maioria das formas sindrômicas existentes de hemimelia tibial são de herança autossômica dominante: a síndrome de Werner, a síndrome de hemimelia tibial associada a diplopodia, a síndrome de hemimelia tibial-micromeliatrigonobraquicefalia e a síndrome da hemimelia tibial associada a mãos e pés fendidos (ectrodactilia), um dos objetos do nosso estudo.

A síndrome da hemimelia tibial associada à ectrodactilia é uma anomalia rara. Normalmente apresenta um padrão de herança autossômica dominante. Sua incidência foi estimada em 1 cada 1.000.000 nascidos vivos (Fernandez-Palazzi e col., 1998). Ela é caracterizada por múltiplas malformações congênitas que incluem ectrodactilia (deformidade de garras de lagosta ou mãos/pés fendidos) e uma grande variedade de fenótipos que incluem ausência de tíbia ou deficiência de ossos longos.

Gurrieri e col. (1996) não detectaram ligação entre a síndrome da hemimelia tibial associada à ectrodactilia com os marcadores moleculares de locos já conhecidos de ectrodactilia não-sindromica. Além disso, Matsuyama e col. (2003) realizaram pesquisas de mutações nos genes HOXD11 e HOXD12 em dois irmãos afetados, mas também não encontraram resultados que explicassem a síndrome. Mais recentemente, Naveed e col. (2007) realizaram uma varredura genômica com SNPs em uma família dos Emirados Árabes Unidos com elevado grau de endocruzamento e vários indivíduos afetados pela síndrome de hemimelia tibial e ectrodactilia. A análise de ligação permitiu que os autores mapeassem dois locos candidatos a conter genes responsáveis pela síndrome nessa família, nas regiões cromossômicas 1q42.2-q43 (SHFLD1OMIM \#119100) e 6q14.1 (SHFLD2 - OMIM \#610685). No entanto, nenhum gene nessas regiões foi pesquisado à procura de mutações. Até pouco tempo atrás, apenas essas duas regiões 
cromossômicas candidatas eram relacionadas à síndrome da hemimelia tibial associada a ectrodactilia. Na publicação recente do nosso grupo foi mapeado um novo loco de hemimelia tibial associada à ectrodactilia na região 17q13.1-17p13.3 (Lezirovitz e col., 2008). A publicação desse estudo levou a criação de mais uma "entrada" no OMIM (SHFLD3 - OMIM \#612576). Essa família foi objeto de estudos moleculares que foram conduzidos nesse projeto de mestrado.

\subsection{Aplasia Fibular}

A aplasia e/ou hipoplasia fibular é um defeito que ocorre ao longo do desenvolvimento e extensão da fíbula e costuma ser a malformação congênita mais comum relacionada a ossos longos (Courtens e col.,2005). O termo aplasia/hipoplasia fibular abrange uma enorme variabilidade de fenótipos, podendo ser muito diferente tanto entre indivíduos afetados quanto entre os membros de um mesmo indivíduo (Lewin e Opitz.,1986).

Casos de agenesia da fíbula podem ocorrer em famílias ou como casos isolados, podem ocorrer como malformação isolada ou como parte de algumas síndromes. Na maioria dos casos descritos na literatura ela é encontrada na forma unilateral, nos casos isolados, ou associada com demais sinais clínicos como braquidactilia (OMIM \#276820), defeitos na ulna e fêmur, malformações em membros superiores (ectrodactilia e polidactilia) e outros. (Lewin e Opitz.,1986; Courtens e col.,2005).

Alguns estudos mostraram que a gravidade da hipoplasia fibular freqüentemente está associada com o número de raios metatársicos ausentes. Segundo Stanitski e Stanitski, (2003) $13 \%$ dos casos de ausência total da fíbula estão associados a pacientes com cinco raios, $40 \%$ associados a pacientes com quatro raios e $47 \%$ associados a pacientes com três raios, sugerindo uma relação inversa entre o número de raios ausentes no pé e a gravidade do encurtamento do 
membro. Alguns genes foram indicados como possíveis responsáveis pela agenesia de fíbula, tais como o GDF5 (Douzgou e col., 2008) localizado na região 20q11 (fator 5 de diferenciação/crescimento) e o TBX3 (Borozdin e col., 2006), localizado na região 12q24, nos quais foram encontradas mutações em indivíduos afetados pela síndromes de hipoplasia fibular e braquidactilia complexa (OMIM \#228900) e em indivíduos com a síndrome Ulnar-mamária respectivamente (OMIM \#181450).

Lewin e Opitz (1986) também descreveram alguns estudos realizados em animais que puderam comprovar que o desenvolvimento da fíbula é comprometido e interrompido por causa de exposição extensiva à radiação, com o uso de ácido retinóico ou de outras substâncias teratogênicas durante a gestação.

Em publicação do nosso grupo foi descrita uma família com uma síndrome aparentemente nova caracterizada por: aplasia/hipoplasia fibular, ectrodactilia, anoníquia/hipoplasia ungueal, entre outros defeitos (Família 2). Essa família é constituída de seis indivíduos afetados com fenótipos de gravidade variável e também foi alvo dos estudos moleculares desenvolvidos no mestrado (Santos e col., 2008).

\subsection{Outros defeitos de membros.}

Alguns outros defeitos de membros como a polidactilia (existência de dígitos supranumerários), a braquidactlia (dígitos desproporcionalmente curtos), a sindactilia (união entre dois ou mais dígitos) e a camptodactilia (impossibilidade de extensão total de um ou mais dígitos) são exemplos de malformações em que já se conhecem alguns genes responsáveis pelas alterações fenotípicas (Tentamy \& McKusick, 1978; Nelson e Holmes, 1980; Crackower e col., 1996; Gilbert.,2003). Esses genes normalmente estão relacionados com as vias de sinalização e 
regulação durante a embriogênese, mais precisamente durante o momento da formação da crista ectodérmica apical (AER) e do posicionamento das células mesodérmicas (Gilbert.,2003). Alguns desses genes aparecem relacionados na tabela 2.

Tabela 2. Relação de alguns genes importantes na formação dos membros durante a embriogênese e suas respectivas localizações.

\begin{tabular}{|l|c|}
\hline \multicolumn{1}{|c|}{$\begin{array}{c}\text { Genes relacionados a } \\
\text { defeitos de membros }\end{array}$} & Localização cromossômica \\
\hline ZRS & $7 \mathrm{q} 36$ \\
\hline SHH & $7 \mathrm{q} 36$ \\
\hline WNT7a & $3 \mathrm{p} 25$ \\
\hline GREM1 & $15 \mathrm{q} 13$ \\
\hline
\end{tabular}

\subsubsection{Sonic hedgehog homolog $(S H H)$ e $Z R S$.}

A manutenção do padrão ântero-posterior dos dígitos durante a embriogênese é importante para a formação correta dos dígitos das mãos e pés. Em 1986, Gasseling e Saunders sugeriram que o eixo ântero-posterior é formado por um pequeno broto de células mesodérmicas que ficam próximas da junção posterior do jovem membro formado (Figura1). Esse centro foi identificado pelos dois pesquisadores como um centro de sinalização responsável pela produção gradual de uma molécula sinalizadora. Essa região recebeu o nome de zona de polarização (ZPA) e é ela a responsável pelo padrão de dígitos dos membros de todos os tetrápodes (Hill e col., 2003). 


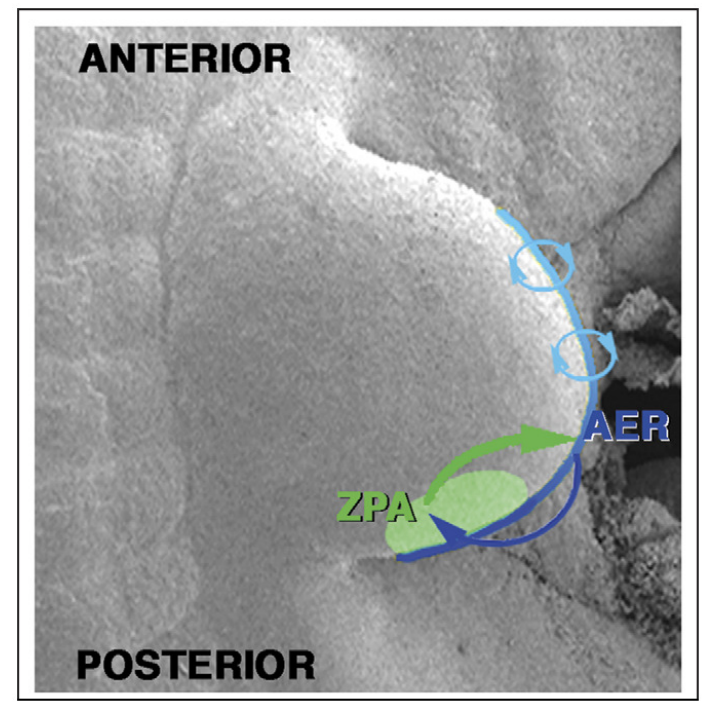

Figura 1. Zona de polarização (ZPA) localizada próximo a junção posterior do membro jovem formado e perpendicular a crista ectodérmica apical (AER) (modificada de Zeller e Zuniga., 2007).

A zona de polarização é um aglomerado de células biologicamente distintas que podem ser manipuladas e transplantadas para locais diferentes do local de origem. Quando se transplanta a ZPA à borda anterior oposta do membro normal temos a formação de um dígito extra em camundongos (Galli e col., 2010). Um dado interessante observado com esses experimentos foi que o padrão e o número dos dígitos são sempre diretamente dependentes do número de células transplantadas (Albuisson e col., 2010). Em 1993, Riddle e colaboradores observaram por meio de hibridação in situ que o gene sonic hedgehog homolog (SHH), homólogo ao gene hedgehog da drosófila, estava expresso especificamente na ZPA. Atualmente já se sabe que é ele o responsável pela sinalização e formação dos dígitos (Lettice e col.,2003). Mutações nesse gene já foram identificadas e relacionadas com o desenvolvimento de dedos supranumerários. Mutações na sequência regulatória ZRS, "enhancer" ou acentuador do gene SHH, também já foram relacionadas com malformações de membros. Sato e col., 2007, Sun e col., 2008 e Wu e col., 2009 identificaram duplicações em ZRS em pacientes com sindactilia do tipo IV e em pacientes com hipoplasia tibial. Wieczorek e col.,2009 identificaram mutações 
específicas em ZRS causando síndrome de Werner e duplicações especificas causando polidactilia associada a sindactilia e polidactilia preaxial. A síndrome de Werner é uma doença autossômica dominante caracterizada por hemimelia tibial associada a polidactilia preaxial das mãos e/ou pés ou mãos com cinco dedos, com ausência do polegar. Nesse estudo foram encontradas mutações pontuais (404G>A e 404G>C) em um nucleotídeo especifico de $Z R S$ e estas foram identificadas como as possíveis causas do fenótipo.

Recentemente, mutações pontuais na sequencia regulatória $Z R S$ foram identificadas em pacientes portadores da polidactilia preaxial do tipo II (Gurnett e col., 2006; Lettice e col., 2008; Li e col., 2009; Albuisson e col., 2010) e em pacientes portadores de polegar trifalângico (Furniss e col., 2008; Farooq e col., 2010). A sequência regulatória ZRS está localizada no cromossomo 7 (7q36.3), no intron 5 do gene $L M B R 1$ e exerce um efeito regulatório temporal e espacial sobre o gene $S H H$ que se encontra a 1 MB a 3' (downstream) do ZRS (Semerci e col., 2009; Wieczorek e col., 2009).

Atualmente, o $S H H$ e o $Z R S$ são consideradas as principais sequências que quando mutadas são responsáveis por defeitos de membros. Furniss e col. (2010) realizaram um estudo de triagem com 202 pacientes que tinham malformações congênitas de membros, por meio de dHPLC e sequenciamento e observaram que dentre os 23 pacientes em que foi descoberta alguma causa genética para o defeito, 5 possuíam mutações em $S H H$ ou em $Z R S$.

\subsubsection{WNT7a.}

Enquanto o eixo ântero-posterior dos membros está sob o controle direto do $S H H$ a partir do mesênquima posterior e da ZPA, o desenvolvimento do eixo dorso-ventral é controlado por proteínas morfogenéticas ósseas (BMPs) a partir do ectoderma ventral, e pelo gene wnt7a, a 
partir do ectoderma dorsal (Woods e col., 2006). Em 1995, Parr e McMahon deletaram o wnt7a em embriões de camundongos e observaram a formação de um aglomerado de células indefinidas formando almofadas em ambas as regiões das patas dos animais, mostrando como o gene Wnt7a é necessário para a padronização dorsal dos membros. Foi observado também que se o ectoderma dorsal fosse retirado ou se a expressão do $w n t 7 a$ fosse inibida, haveria uma redução drástica na expressão do gene $s h h$, indicando que a manutenção da expressão de $S H H$ depende da sinalização que vem da região dorsal (Furniss e col., 2009).

A síndrome congênita da palma das mãos é uma síndrome rara que envolve uma variedade de fenótipos como: palmas das mãos constituídas por uma pele grossa e anormal, sem cabelos ou unhas, deficiência ulnar bilateral de raios, hipoplasia dos membros superiores e graves distúrbios nos membros posteriores (Al-Qattan e col., 2009). Al-Qattan e col. (2009) relatam o caso de um paciente com a síndrome congênita da palma das mãos em que foi identificada uma mutação (substituição de uma guanina por uma adenina) no exon 4 do gene $W N T 7 a$, mostrando como esse gene pode estar relacionado a malformações dos membros.

Outra síndrome também relacionada a mutações em WNT7A é a síndrome de AlAwadi/Raas-Rothschild, uma doença autossômica recessiva caracterizada por malformações graves dos membros superiores e inferiores e hipoplasia da bacia. Woods e col, (2009) descreveram dois casos em que a mutação (substituição de uma timina por uma citosina na posição 1179) em $W N T 7 a$ foi identificada resultando em troca de uma arginina por uma cisteína, levando à perda total da função de WNT7a.

Estudos com camundongos knockout em relação ao gene Wnt7a também já foram realizados e mostraram um fenótipo em que os camundongos mutantes apresentam diminuição e 
encurtamento dos dígitos das mãos e perda de falange do autópode, reforçando a sua importância no desenvolvimento de membros em camundongos (Adamska e col., 2005).

Além disso, o WNT7a também é importante, pois induz a ativação de um gene expresso no mesênquima dorsal, o LMX1 (Gilbert.,2003).

\subsubsection{GREM1.}

O gene Sonic Hedgehog (SHH), como visto anteriormente, é amplamente expresso na região de polarização e seu produto instrui as células em relação ao seu posicionamento ântero-posterior e especifica a identidade tetrápode dos dígitos. A expressão de $S H H$ é regulada por feedback e pelas demais interações entre as células epiteliais mesenquimais que se localizam entre a AER (expressando $F G F s)$ e as células epiteliais mesenquimais localizadas na região posterior e distal, que expressam o GREMLIN1, conhecido como GREM1 (Gilbert., 2003). O gene GREM1 é ativado paralelamente à expressão de $S H H$ e $B M P$, permitindo a sinalização por meio de feedback (Zeller e Zuniga., 2007).

Alguns estudos recentes mostram que a perda de função por mutações em SHH e GREMI podem perturbar o estabelecimento do eixo ântero-posterior, ocasionando perturbações no desenvolvimento de membros (Zeller e Zuniga., 2007). Nesse trabalho, há a criação de um camundongo knockout para o gene Greml que apresenta algumas malformações dos membros como perda de dígitos, sindactilia e até fusão da ulna com o rádio. Por outro lado, a sinalização ectópica de $S H H$ é uma importante causa de formação extra de dígitos na região anterior (polidactilia preaxial). Portanto, conclui-se que a regulação dinâmica da expressão dos genes SHH e GREMI é um fator importante na formação normal dos membros em desenvolvimento (Zeller e Zuniga.,2007). 
Zhou e col., 2009 também estudaram camundongos knockout para o gene GREM1, sequência regulatória de FORMIN1 e para o gene FORMIN1 e pode observar fenótipos onde os camundongos apresentavam uma redução do número de dígitos para quatro, um metatarso posterior deformado, fusão de tecidos moles das falanges e ausência da fíbula. Em 2009, Bénazet confirmaram o mesmo fenótipo observado por Zeller e Zuniga., 2007 em camundongos knockout em relação ao gene GREM1. Deformidades nos membros do camundongo como redução de dígitos, sindactilia, sinostose rádio-ulnar, defeitos renais variáveis e fíbula ausente são causadas pela perda de função de GREMI (Ivanov e col., 2010). Além disso, uma super expressão de GREM1 no desenvolvimento de membros em galinhas reprime a morte celular programada do mesênquima interdigital, resultando em membranas interdigitais (Ivanov e col., 2010). Recentemente identificaram-se rearranjos cromossômicos abrangendo o GREMI em humanos, levando a defeitos de membros. Ivanov e col., (2010) localizaram uma duplicação de $1,7 \mathrm{Mb}$ incluindo o gene GREM1 em pacientes com oligosindactilia nas mãos.

\subsection{Estratégias de mapeamento de doenças genéticas.}

O mapeamento de genes responsáveis por doenças humanas tem sido realizado por meio de duas estratégias principais. A primeira delas é por meio do estabelecimento de correlações entre alterações cromossômicas e fenótipos anormais (doenças). A segunda delas compreende os estudos de ligação em grandes famílias com vários indivíduos afetados por uma doença, seguidos de sequenciamento de genes mapeados nas regiões candidatas.

As alterações cromossômicas associadas a fenótipos anormais sugere que os pontos de quebra nos cromossomos, a duplicação ou a deleção de certos segmentos do cromossomo possam estar relacionados ao fenótipo, interferindo na expressão de um ou mais genes. Essas alterações 
podem interferir na expressão de alguns genes por interromper suas regiões codificadoras, por mudar as posições dos genes, por separá-los de seus promotores ou de outros elementos regulatórios ou por colocá-los em regiões onde sua expressão seria inibida ou diminuída. Normalmente as anomalias cromossômicas estão relacionadas a várias alterações fenotípicas, caracterizando uma síndrome, já que costumam influenciar a expressão de vários genes simultaneamente. Como foi mostrado anteriormente, as alterações cromossômicas foram uma das estratégias que permitiram a identificação de genes associados à ectrodactlia sindrômica, ectrodactilia não-sindrômica e outros genes de defeitos de membros.

Os estudos de ligação baseiam-se no conceito de ligação genética, que consiste na tendência de alelos de dois locos distintos, mas localizados muito próximos numa mesma região cromossômica, serem transmitidos em conjunto como uma só unidade na meiose. Dessa forma, os estudos de ligação realizados em grandes famílias com indivíduos afetados visam analisar a co-segregação de dois locos nas genealogias. Esses locos podem ser tanto os genes responsáveis por determinadas características fenotípicas quanto marcadores genéticos.

Marcadores genéticos são considerados quaisquer sequências protéicas ou de DNA polimórficas, em uma localização cromossômica conhecida. Em geral, são utilizados para se estudar a transmissão de um segmento cromossômico de uma geração para a outra em uma genealogia e compará-la com o padrão de transmissão de uma doença. Desse modo, pode-se definir uma região cromossômica candidata a conter o gene responsável pela doença (Evans e Cardon., 2004). Um marcador genético para ser informativo precisa se apresentar em alta frequência de heterozigose na população, ou seja, deve haver uma grande probabilidade de que uma pessoa selecionada aleatoriamente na população seja heterozigótica em relação a ele. Os microssatélites são um dos tipos de marcadores mais utilizados nos estudos de ligação devido ao 
fato de apresentarem muitos alelos diferentes e, em geral, apresentarem-se na população em alta taxa de heterozigose (Evans e Cardon., 2004). Os microssatélites são sequências de DNA repetitivas constituídas por unidades de repetição em tandem e essa unidade de repetição não apresenta, em geral, mais que 10pb (Kruglyak e Lander 1995). O número de unidades de repetição em cada loco de microssatélite varia de indivíduo para indivíduo, caracterizando polimorfismos na população.

Outro tipo de marcador muito utilizado atualmente em estudos de mapeamento são os polimorfismos de nucleotídeo único. Os polimorfismos de base única (SNPs - Single Nucleotide Polymorphisms) são a forma mais frequente de variação na sequência de DNA encontrada no genoma humano e podem ser definidos como regiões pontuais do DNA, onde o nucleotídeo seja variável na população. Como os SNPs possuem, mais frequentemente, apenas dois alelos, sua genotipagem pode ser facilmente automatizada (Kruglyak., 1997). Atualmente existem métodos fáceis e rápidos para se genotipar cerca de até 1.800.0000 SNPs de uma única vez por meio de arrays de oligonucleotideos de alta densidade. Kruglyak (1997) realizou uma análise comparando o uso de microssatélites e SNPs em estudos de ligação e concluiu que os SNPs, mesmo sendo menos polimórficos, são muito mais informativos devido a grande quantidade existente no genoma (mais de 3 milhões segundo http://hapmap.ncbi.nlm.nih.gov/). Apesar dos SNPs possuírem uma capacidade de extração de informações inferior a dos microssatélites considerando-se cada SNP individualmente, por estarem presentes no genoma em enorme quantidade (mais de 1 a cada 1000 pares de bases) oferecem uma ferramenta mais eficiente para varreduras de genômicas iniciais (Kruglyak e col.,1997).

Os estudos de ligação, seja por meio do uso de microssatélites, ou de marcadores bialélicos, são considerados uma estratégia muito eficiente quando são disponíveis grandes 
famílias com vários indivíduos afetados pela mesma doença. Esses fatos, aliados à disponibilidade de três famílias com vários indivíduos afetados por diferentes tipos de defeitos de membros, motivaram o estudo molecular e o mapeamento dos genes responsáveis por tais condições. 


\section{Objetivos}

Nossa pesquisa teve como objetivo geral mapear novos locos e identificar novas mutações relacionadas a defeitos de membros em famílias brasileiras.

Os objetivos específicos desse estudo foram:

$\mathrm{Na}$ família 1, sequenciar genes localizados na região já previamente mapeada como candidata 17p13.1-17p13.3, a fim de identificar o gene relacionado à síndrome da hemimelia tibial associada à ectrodactilia.

Na família 2, identificar o gene ou mapear a região cromossômica candidata a conter o gene responsável pela nova síndrome em questão, por meio de estudos de ligação e sequenciamento de genes. Esse estudo teve início com marcadores de microssatélites próximos a locos já mapeados de ectrodactilia, hemimelia tibial, agenesia de fíbula e outros defeitos de membros e, como essas regiões foram excluídas, a varredura genômica com arrays de SNPs foi executada. O sequenciamento de alguns genes candidatos foi realizado.

Na família 3, identificar o gene ou mapear a região cromossômica candidata a conter o gene responsável pela condição, por meio de estudos de ligação. Esse estudo também teve início com marcadores de microssatélites próximos a locos já mapeados de ectrodactilia, hemimelia tibial, agenesia de fíbula e outros defeitos de membros e, como essas regiões foram excluídas, a varredura genômica com arrays de SNPs foi executada. O sequenciamento de alguns genes candidatos foi realizado. 


\section{Material e Métodos}

\section{1- Famílias}

\section{Família 1}

A família 1 (Figura 2) foi averiguada no Serviço de Aconselhamento Genético do Laboratório de Genética Humana do Departamento de Genética e Biologia Evolutiva (IBUSP) no ano de 1991. Durante o projeto de pós-doutoramento "Estudo da Síndrome de Hemimelia Tibial associada à Ectrodactilia (HTE)", da Dra. Sylvia Pedrosa Maestrelli, foi realizado o estudo genético-clínico da família, que apresentava 16 indivíduos afetados por ectrodactilia associada a hemimelia tibial, de herança autossômica dominante e penetrância reduzida (34\%). Foram obtidas amostras de DNA de 43 pessoas, 11 afetadas, sete portadores certos do gene alterado fenotipicamente normais, seis cônjuges e 19 pessoas fenotipicamente normais (Lezirovitz e col., 2008). Os estudos de mapeamento permitiram delimitar a região candidata a um segmento de aproximadamente $370 \mathrm{~Kb}$, contendo 21 genes (Ensemble 58:Maio 2010 http://may2010.archive.ensembl.org/index.html). Detalhes do quadro clínico podem ser encontrados em Lezirovitz e col (2008). Apresentamos na Figura 3, uma descrição clínica resumida dos principais achados. 


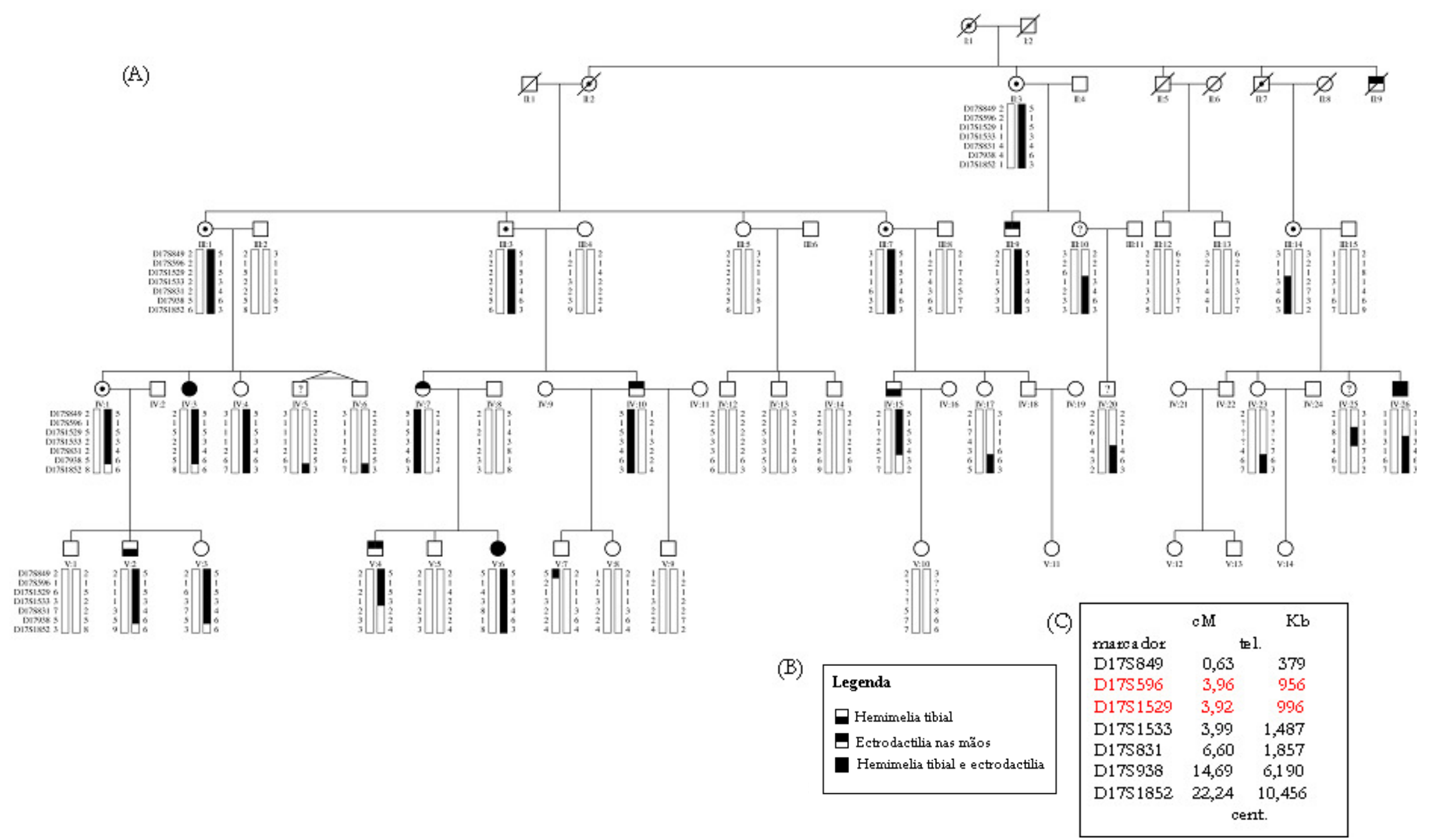

Figura 2.Heredograma da família 1 mostrando os haplótipos do cromossomo 17. (B) Legenda do heredograma. (C) Mapa com as distâncias em cM e Kb entre os microssatélites analisados, onde se pôde definir a região cromossômica 17p13.3-17p13 como candidata (modificado de Lezirovitz e col., 2008). 

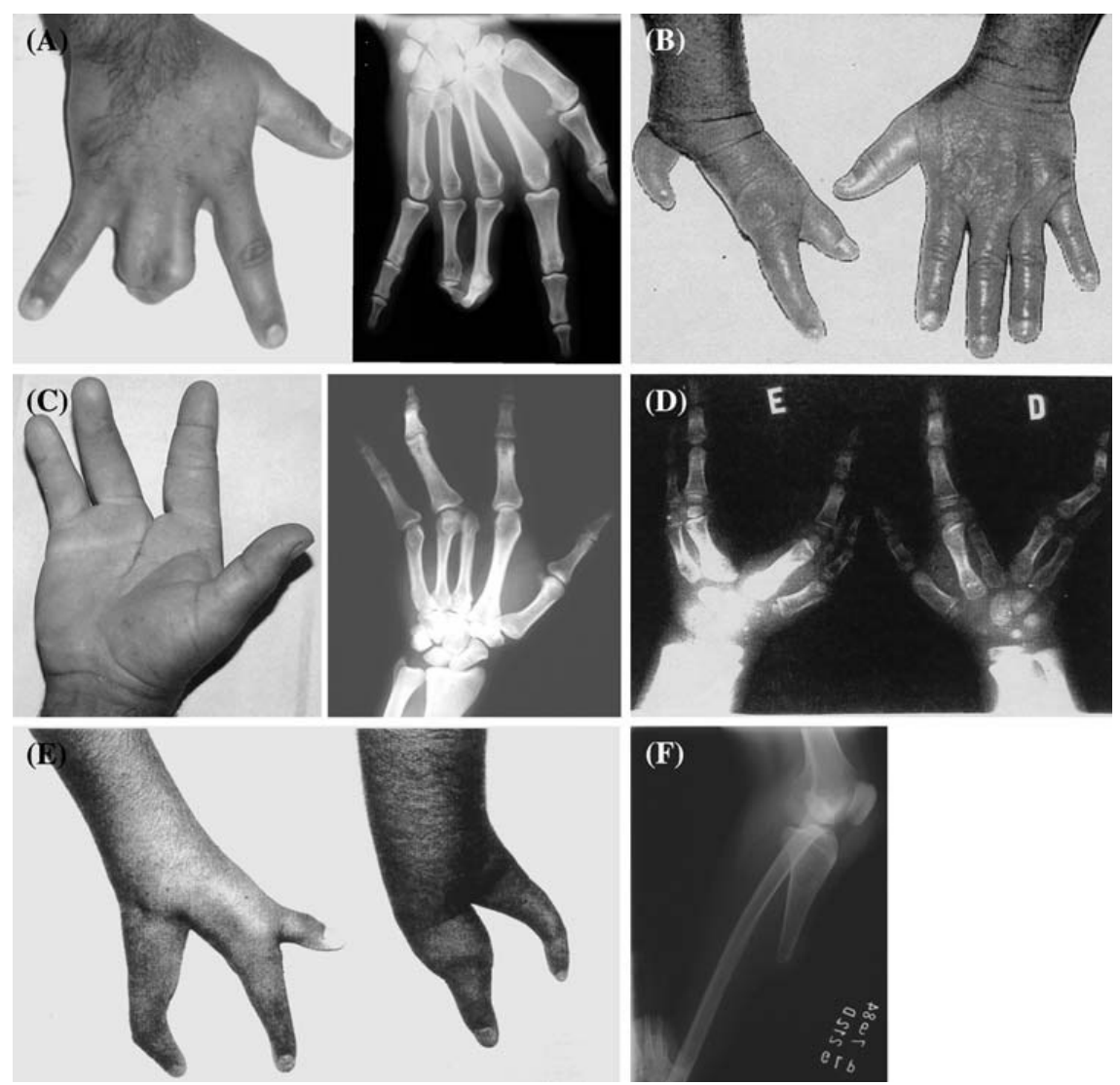

Figura 3. Manifestações clinicas da família 1. (A) Paciente V:4 com sindactilia e camptodactilia; Raio-X da mão direita mostrando o defeito dos raios centrais da mão. (B) Paciente IV:7 com ectrodactilia à direita. (C) Paciente IV:10 com ectrodactlia (ausência do $3^{\circ}$ dígito) e raio-X correspondente. (D) Raio-X do paciente IV:26 com ectrodactilia. (E) Paciente V:6 com ectrodactilia em ambas as mãos. (F) Raio-X mostrando hemimelia tibial à direita no paciente IV:3 (modificado de Lezirovitz e col., 2008). 


\section{Família 2}

A família 2 (Figura 4) foi averiguada pela Dra. Silvana C. Santos no projeto “Consanguinidade em populações do Nordeste Brasileiro: da prospecção de doenças genéticas à intervenção por meio de educação genética" coordenado pelo Dr. Paulo Alberto Otto (CNPq). O quadro clínico dos indivíduos afetados foi descrito detalhadamente na publicação de Santos e col., 2008.

A família reside em Riacho de Santana, uma pequena cidade na região ocidental do nordeste brasileiro, no estado do Rio Grande do Norte. É uma família de descendentes de europeus, principalmente de portugueses, que colonizaram a região há aproximadamente cem anos.

Ela é constituída por seis indivíduos afetados por uma síndrome aparentemente nova caracterizada por aplasia/hipoplasia fibular, ectrodactilia e anoníquia/hipoplasia ungueal, entre outros defeitos.

Os casamentos consanguíneos dentro da comunidade nordestina ocorrem com frequência e isso também pode ser observado na família em questão.

As características fenotípicas e o padrão de transmissão no heredograma sugerem herança do defeito compatível com mecanismo autossômico dominante de penetrância incompleta. O padrão de herança autossômico recessivo não pode ser descartado devido ao alto grau de endogamia da família.

Obtivemos amostras de DNA de 13 indivíduos da família, seis afetados e sete fenotipicamente normais.

Apresentamos na Figura 5 um resumo dos principais achados clínicos nessa família. 


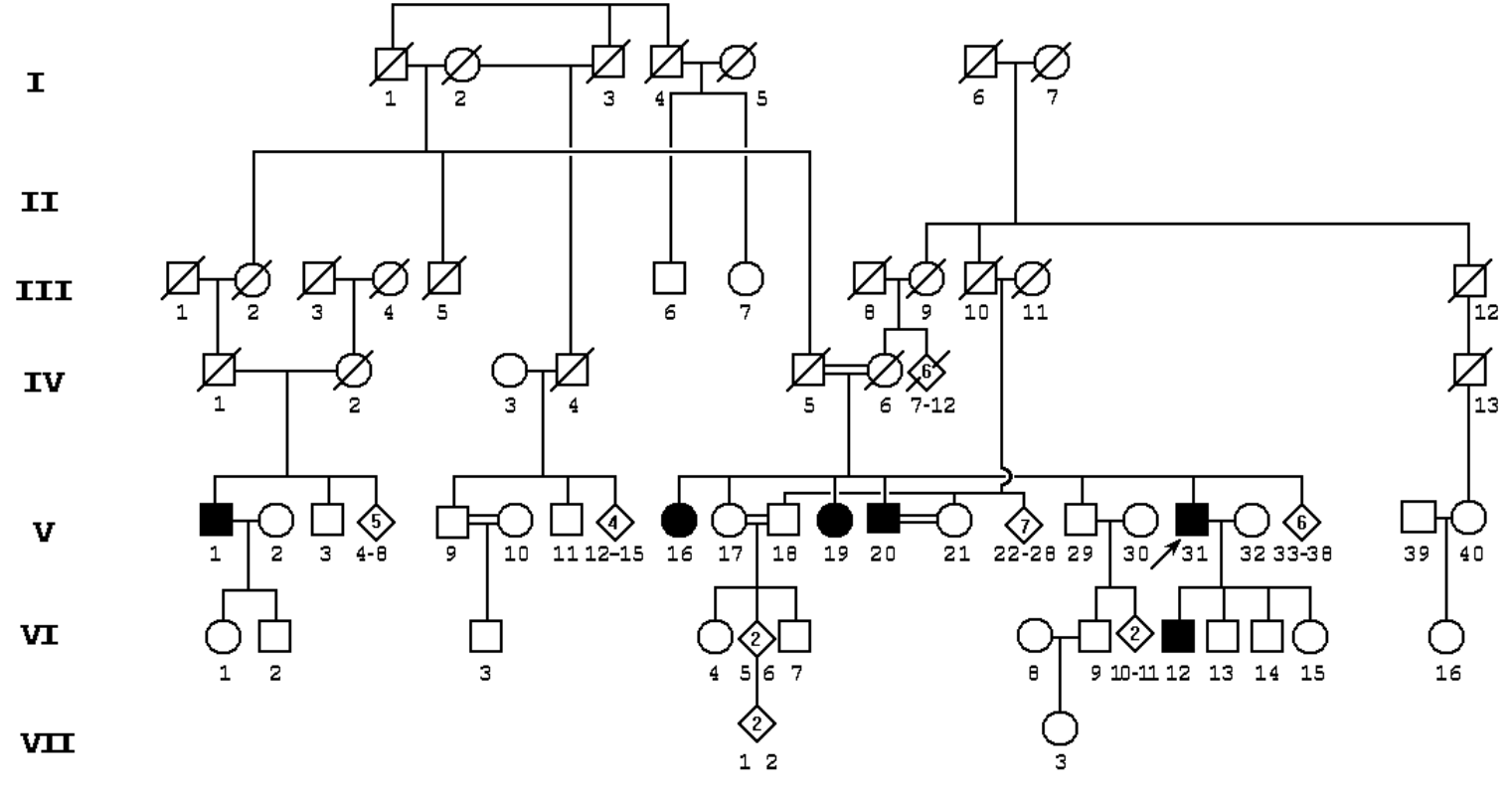

Figura 4. Heredograma da família 2. Os indivíduos assinalados em preto são afetados por um quadro clinico variável de malformações de mãos e pés, incluindo aplasia/hipoplasia fibular (modificado de Santos e col., 2008).
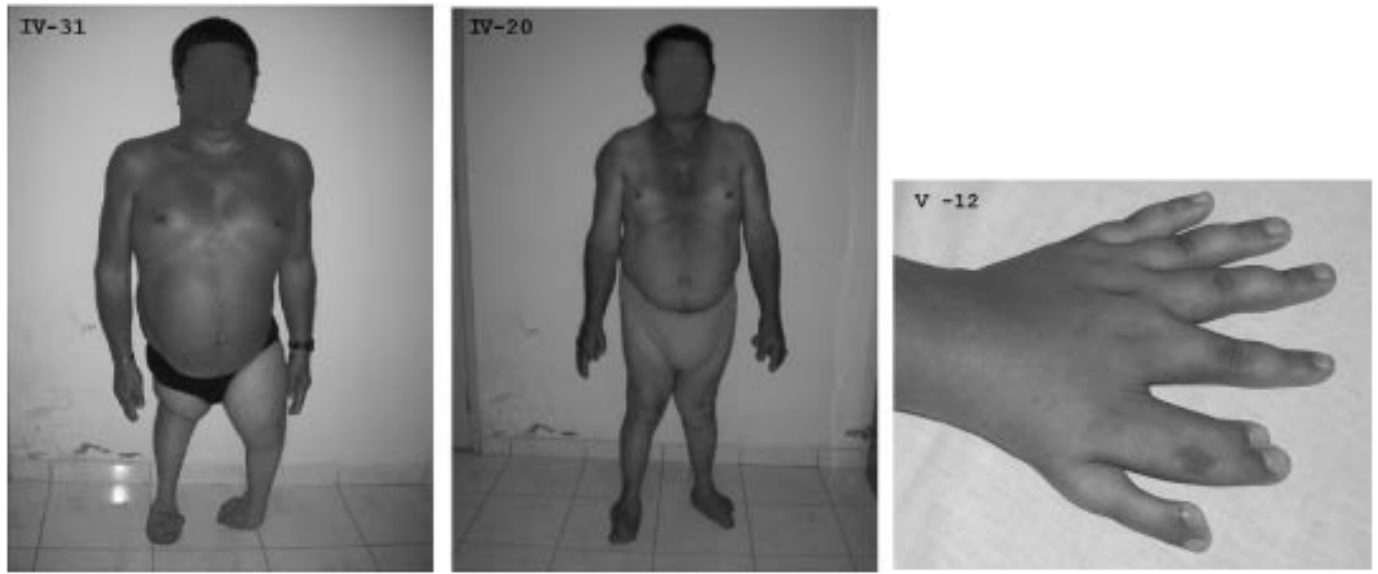

Figura 5. Indivíduos IV:31 e IV:20 com hipoplasia fibular e individuo V-12, com polidactilia à esquerda (modificado de Santos e col., 2008). 


\section{Família 3}

A família 3 (figura 6) foi averiguada em estudos genéticos conduzidos por nosso laboratório em remanescentes de quilombos do Vale do Ribeira (SP), no âmbito do projeto de doutorado "Fatores genéticos associados à hipertensão em populações afro-brasileira" desenvolvido por Lilian Kimura (Processo FAPESP: 2007/53584-9).

A família tem três indivíduos afetados por um quadro variável de defeitos de extremidades dos membros (polissindactilia, sindactilia, camptodactilia e defeitos ungueais), sem outros dismorfias associadas. Um quarto individuo afetado falecera ainda criança vitima de um acidente.

O quadro clínico é muito variável entre os indivíduos da família. Atualmente todos os membros da família que possuem alguma alteração nos membros já passaram por cirurgias para correção e melhoria do problema.

Pelas características fenotípicas e pelo padrão de transmissão, o heredograma sugere um mecanismo de herança compatível com o autossômico dominante com penetrância completa. 


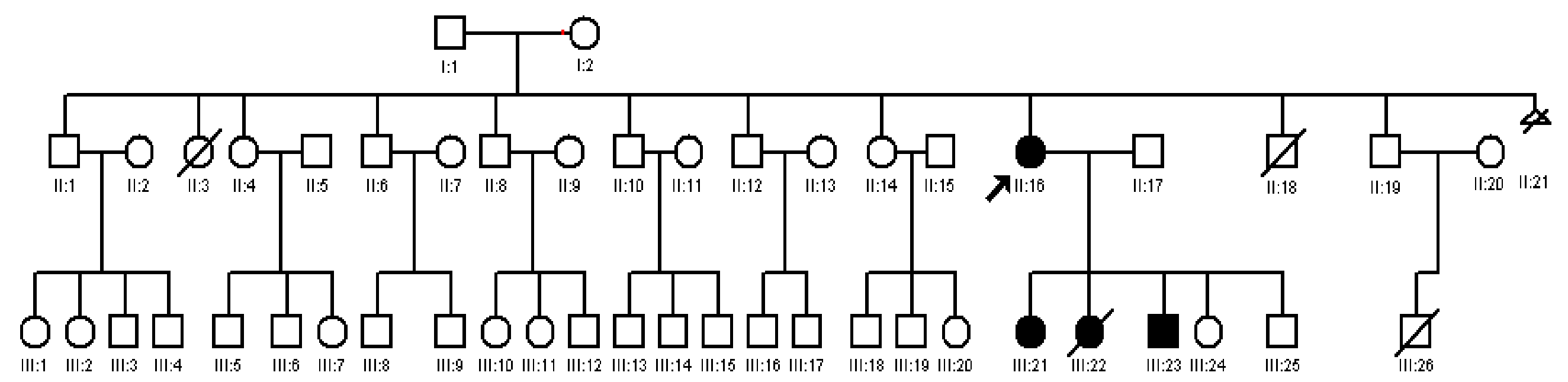

Figura 6. Heredograma da família 3. Os indivíduos assinalados em preto são afetados por um quadro clínico muito variado de malformações de membros, incluindo polidactilia, sindactilia, e camptodactilia. 


\section{$\underline{\text { Caracterização clínica }}$}

Apresentamos abaixo um resumo dos achados clínicos dos três afetados estudados durante o mestrado. A descrição clínica do quarto indivíduo afetado falecido também está apresentada a seguir.

\section{Paciente II:16}

A propósita nasceu com todos os dedos fundidos e dobrados sobre a palma da mão (cerca de $90^{\circ}$ ). O diagnóstico do defeito recebido na infância foi de polidactilia e sindactilia nos dígitos da mão esquerda e da mão direita. Aos 2 anos de idade passou por cirurgia corretiva. Atualmente apresenta polegares oponíveis e suas unhas crescem normalmente (Figura 7).

A paciente não apresenta quaisquer outros sinais clínicos. Não tivemos acesso aos exames de raios- $\mathrm{X}$ dessa paciente.

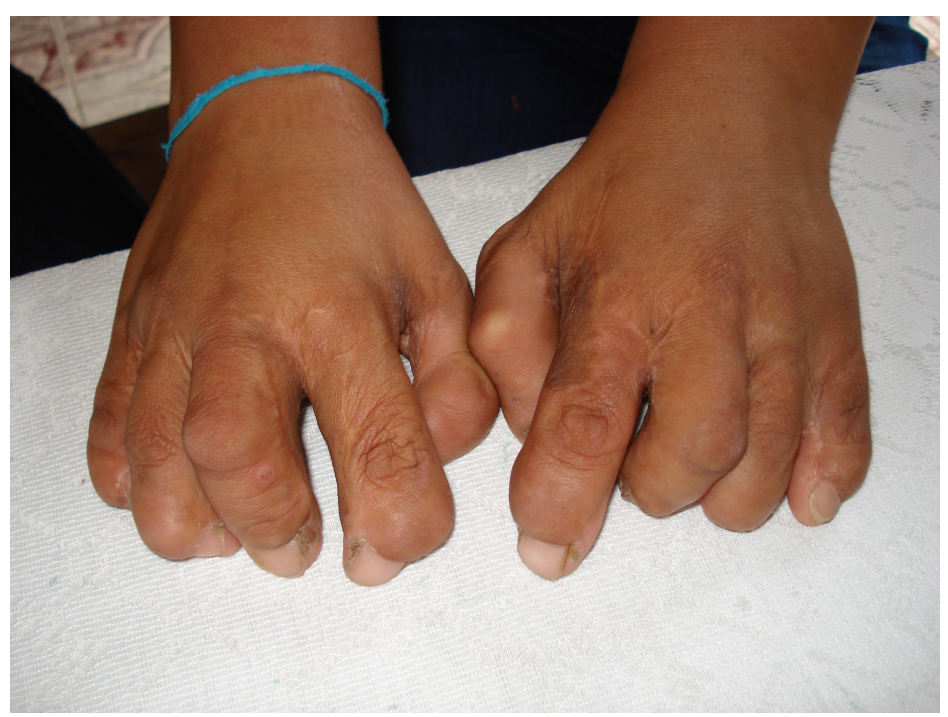

Figura 7. Foto do dorso das mãos da paciente II:16, após cirurgia corretiva. 


\section{Paciente III:21}

Foi submetida a três cirurgias corretivas quando ainda criança. Na primeira foram liberados o $1^{\circ}$ dígito de ambas as mãos, na segunda cirurgia foram liberados o $2^{\circ}$ e o $5^{\circ}$ dígitos e na ultima cirurgia, o dedo médio ( $3^{\circ}$ dígito). Atualmente apresenta à direita camptodactilia, polegar não oponível e a unha não desenvolvida. À esquerda o polegar é não oponível, virado para dentro, cuja unha também não se desenvolve (Figura 8). O paciente não apresenta quaisquer outros sinais clínicos. Não tivemos acesso aos exames de raios-X dessa paciente.

A

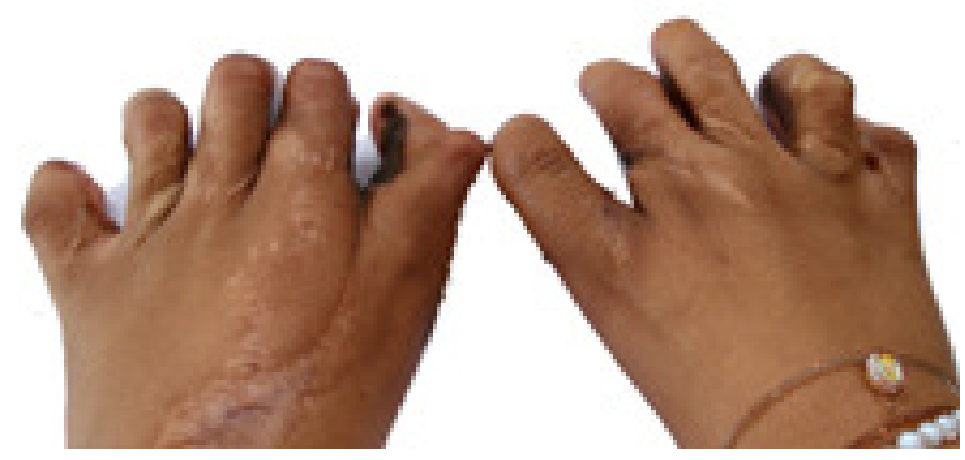

B
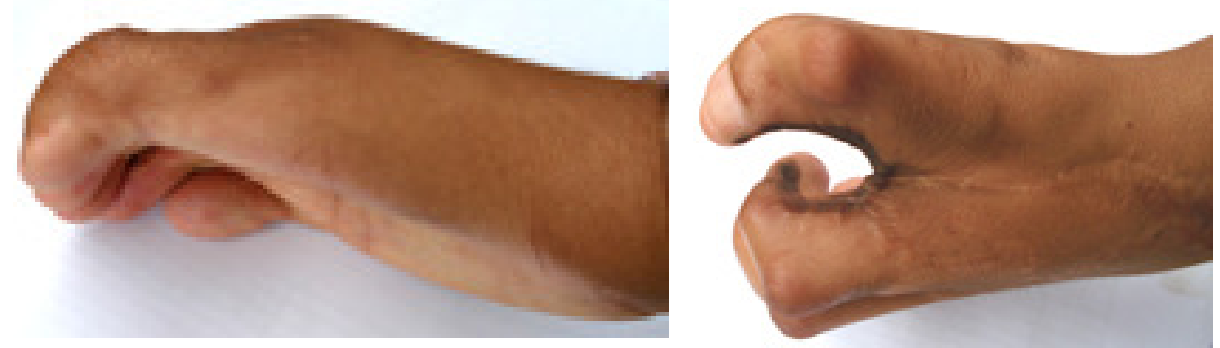

Figura 8. Foto do dorso das mãos da paciente III:21 (A). Foto da lateral das mãos da paciente III:21 (B). 


\section{Paciente III:22}

A afetada III:22, já falecida, também recebeu o diagnóstico de polidactilia e sindactilia. Passou por duas cirurgias corretivas e faleceu aos 7 anos de idade por atropelamento. Aparentemente a paciente não apresentava outros sinais clínicos.

\section{Paciente III:23}

O paciente III:23 (figura 9) apresenta camptodactilia à direita, polegar oponível e duplicação da falange proximal do polegar. Na mão esquerda apresenta camptodactilia, sindactilia de 3 dedos ( 2 extras pré-axiais e o polegar), sendo que a unha cresce normalmente. Os pés do paciente apresentam sindactilia bilateral $\left(2^{\circ}\right.$ e $3^{\circ}, 3^{\circ}$ e $4^{\circ}, 5^{\circ}$ e $6^{\circ}$ dígitos $)$. O paciente não apresenta quaisquer outros sinais clínicos. Não tivemos acesso aos exames de raios-X desse paciente.

\section{A}
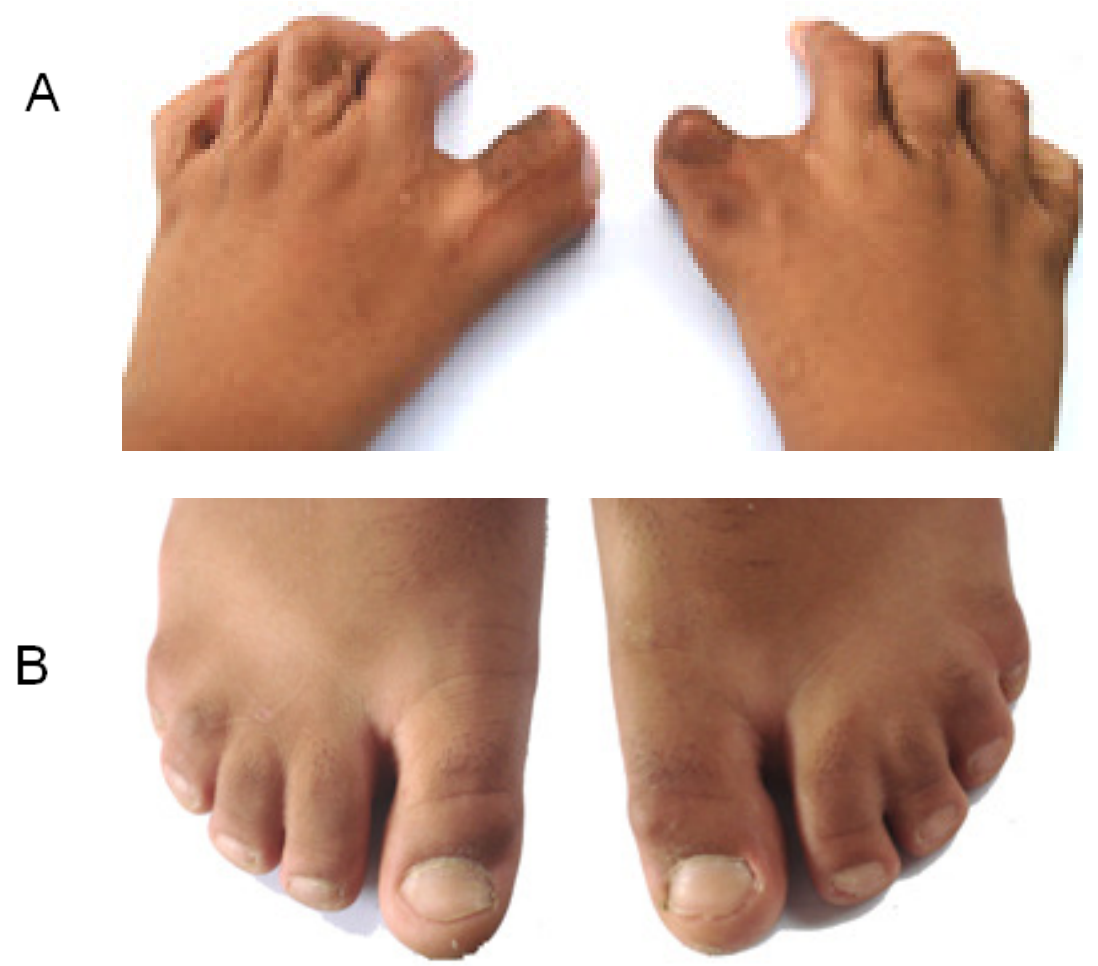

Figura 9. Foto do dorso das mãos do paciente III:23. (A). Foto dos pés do paciente III:21 (B). 


\section{2 - Métodos}

Nossa estratégia na família 1 foi o sequenciamento dos exons de genes localizados na região cromossômica candidata já mapeada. Os genes nessa região são: $A B R, P R P F 8$, SERPINF1, SERPINF2, YWHAE, RTN4RL1, RPA1, CRK, SMYD4, MGC14376, RILP, TUSC5, BHLHA9, TLCD2, C17orf91 MYO1C, SKIP, WDR81, PITPNA, SCARF1 e SLC43A2 (Ensemble 58: Maio 2010 - http://may2010.archive.ensembl.org/index.html).

Primeiramente, foram sequenciados os genes sugeridos pelo software "ENDEAVOUR" (http://homes.esat.kuleuven.be/ bioiuser/endeavour/index.php) e pelo software "PosMed"SM", (Yoshida e col., 2009) como melhores candidatos, com o objetivo de identificar as possíveis mutações responsáveis. As sequências de primers para amplificação dos genes da região candidata foram desenhadas por meio do pacote computacional Primer3 (Rozen and Skaletsky., 2000).

Nossa estratégia nas famílias 2 e 3 foi a realização de estudos preliminares de ligação com microssatélites que permitiriam excluir a ligação com as regiões cromossômicas já conhecidas associadas a malformações de membros. Em seguida foram sequenciados diretamente alguns genes candidatos selecionados a partir da literatura (SHH, ZRS, WNT7a, WNT1Ob, GREM1).

Dado que mutações não foram identificadas nessas duas famílias, foi realizada a varredura genômica com o kit de SNPs “Affymetrix GeneChip® Human Mapping 50K Array”

\subsubsection{Extração do DNA}

O DNA foi extraído a partir de linfócitos de sangue periférico utilizando-se a técnica de extração com fenol/clorofórmio, ou por meio dos Kits: "Easy-DNATM Kit (Version D) Genomic 
DNA Isolation" da Invitrogen, ou "Perfect gDNA Blood Mini Isolation Kit" da Eppendorf ou "GFX Genomic Blood DNA Purification Kit" da Amershan Biosciences. No caso das amostras mais recentemente colhidas, a extração foi realizada pelo aparelho Autopure LS (Gentra Systems) disponível no Centro de Estudos do Genoma Humano, IBUSP.

\subsubsection{Estudos cromossômicos}

O estudo do cariótipo do indivíduo V:2 da família 1 e do indivíduo II:16 da família 3 foi realizado no laboratório da Dra. Angela M. Vianna Morgante, a partir de linfócitos de sangue periférico cultivados por 72 horas. Foram analisadas 18 metáfases após bandamento G.

\subsubsection{Array-CGH}

Foi realizada a investigação de alterações cromossômicas submicroscópicas por meio do microarray-Comparative Genomic Hybridrization (Human Genome CGH Microarray Kit 44K da Agilent Technologies) nos indivíduos IV:3, V:6 e IV:15 da família 1, no individuo V:31 da família 2 e no individuo II:16 da família 3. Essa investigação foi conduzida no laboratório da Dra. Carla Rosenberg, pela pós-doutoranda Erika Freitas.

\subsubsection{Estudos de ligação com microssatélites}

Os estudos de microssatélites foram realizados utilizando-se o kit “ABI PRISM ${ }^{\circledR}$ Linkage Mapping Set v. 2.5-MD10" da Applied Biosystems. Esse "Kit" é composto de 382 marcadores de microssatélites autossômicos distantes cerca de 10cM um do outro e distribuídos por todos os cromossomos. Foram selecionados para estudo os microssatélites de regiões próximas a locos já mapeados candidatos a conter genes responsáveis pela ectrodactilia, hemimelia tibial e aplasia 
fibular.

Para a análise de todos os microssatélites, cujo primer forward é marcado com fluorescência, os produtos da amplificação foram separados por meio de eletroforese em capilar no aparelho MegaBACE ${ }^{\mathrm{TM}} 1000$ (sistema com 96 capilares) da Amersham Biosciences, juntamente com o padrão de peso molecular "MegaBACE ${ }^{\mathrm{TM}}$ ET 550-R Size Standard" que acompanha o aparelho. A análise dos marcadores moleculares fluorescentes foi realizada utilizando o software "Genetic Profiler versão 1.5" que acompanha o aparelho MegaBACE ${ }^{\mathrm{TM}}$ 1000. Parte dos microssatelites também foram separados por meio de eletroforese em capilar no aparelho ABI3730 da Applied Biosystems. A análise dos marcadores moleculares fluorescentes nesses casos foi realizada utilizando o software "GeneMapper." que acompanha o aparelho ABI3730.

Nesses casos as condições de amplificação utilizadas eram as mesmas utilizadas para o aparelho MegaBACE ${ }^{\mathrm{TM}} 1000$. A única diferença de protocolo residia na preparação das amostras para a corrida nos capilares. Para essa preparação as amostras e marcadores eram misturados à formamida. Era necessário $9,0 \mu \mathrm{l}$ de formamida para cada $0,075 \mu 1$ de padrão peso molecular (ET550-R ou GS500-ROX) e $2 \mu$ de produto de PCR (diluição 1:20).

\section{Condições de amplificação}

Para a amplificação dos microssatélites do kit, o volume final de reação foi $7 \mu 1$ ou $10 \mu \mathrm{l}$, contendo entre 50 ng e 100 ng de DNA genômico, entre 0,3 e 0,66 $\mu 1$ de uma mistura de primers a $5 \mu \mathrm{M}, 1,5 \mathrm{U}$ de Taq polimerase e 0,27 $\mathrm{mM}$ dCTP, 0,27 $\mathrm{mM}$ dTTP, 0,27 $\mathrm{mM}$ dGTP e 0,27 $\mathrm{mM}$ dATP; 1,3 a 2,0 mM $\mathrm{MgCl}_{2}, 20 \mathrm{mM}$ TRIS $\mathrm{pH}=8,4 ; 50 \mathrm{mM} \mathrm{KCl}$. Conforme instruções do fabricante, as condições de amplificação foram: desnaturação inicial por 12 min a $95^{\circ} \mathrm{C}, 10$ ciclos 
de $15 \mathrm{~s}$ a $94^{\circ} \mathrm{C}$, annealing a $55^{\circ} \mathrm{C}$ ou $54^{\circ} \mathrm{C}$ por $15 \mathrm{~s}$ e $30 \mathrm{~s}$ a $72^{\circ} \mathrm{C}, 20$ ciclos de $15 \mathrm{~s}$ a $89^{\circ} \mathrm{C}$, annealing a $55^{\circ} \mathrm{C}$ ou $54^{\circ} \mathrm{C}$ por $15 \mathrm{~s}$ e extensão a $72^{\circ} \mathrm{C}$ por $30 \mathrm{~s}$, extensão final a $72^{\circ} \mathrm{C}$ por $10 \mathrm{~min}$.

\subsubsection{Varredura Genômica por meio de SNPs}

Para a realização da varredura utilizou-se o array de SNPs do kit "Affymetrix GeneChip® Human Mapping 50K Array". Os arrays desse kit podem genotipar cerca de 50.000 SNPs em uma única reação.

O microarray de SNPs consiste em milhares de sondas de DNA espalhadas ao longo do genoma as quais são "impressas" em um chip de vidro. Essas sondas são alelo-específicas para cada uma das duas possibilidades do SNP em questão (Lindblad-Toh e col., 2000). Na reação, ocorre a hibridação de DNA do paciente com as sondas do chip (Uniscience website; GeneChip Mapping 50K 2.0 Assay Manual).

Primeiramente, fragmentou-se $5 \mu 1$ de DNA (diluído a concentração de 50 ng/ $\mu$ l) extraído a partir de linfócitos de sangue periférico por meio de digestão com uma enzima de restrição (XbaI ou HindII). Em seguida, passou-se para o processo de ligação onde um adaptador sintético foi adicionado às pontas não coesivas dos fragmentos digeridos. Utilizando um único par de primers, amplificaram-se os fragmentos digeridos e após a PCR purificou-se o produto. Para que os fragmentos de DNA se ligassem nas sondas corretamente era necessário que estivessem em um tamanho específico, entre cerca de 250 a 1000bp. Para isso, realizou-se então o processo de fragmentação dos produtos de PCR. Por último, a amostra de produto fragmentado foi marcada com fluoróforos permitindo assim emitir fluorescência no momento que o DNA se liga a sua sonda especifica. Desse modo, quando é feita a leitura do chip, são verificados os padrões diferentes de fluorescência, que variam em função do alelo em cada SNP que o indivíduo 
apresenta. Seguiu-se exatamente o protocolo do fabricante para a realização desses experimentos (GeneChip Mapping 10K 2.0 Assay Manual).

\subsubsection{Sequenciamento do DNA}

O sequenciamento do DNA foi utilizado para identificar mutações nos genes candidatos a explicar os defeitos de membros nas famílias. As sequências de todos os primers para sequenciar genes candidatos estão apresentadas na tabela 3 .

As reações de PCR para a amplificação dos fragmentos contendo os exons dos genes pesquisados foram preparadas em duplicata. A purificação do produto da PCR foi feita por meio do "Illustra GFX PCR DNA and gel purification Kit" (GE healthcare), segundo instruções do fabricante. Em seguida os produtos purificados foram quantificados em gel de agarose $2 \%$, utilizando como padrão o "low DNA mass ladder" (INVITROGEN). O produto purificado e quantificado foi então submetido à reação de sequenciamento. Os indivíduos selecionados tiveram as amostras sequenciadas com os primers Forward e Reverse. Os produtos da reação de sequenciamento foram precipitados com Sephadex (Amersham Biosciences), seguindo as instruções do fabricante. Após a purificação por Sephadex, as amostras da reação de seqüenciamento foram analisadas no equipamento $\mathrm{MegaBACE}^{\mathrm{TM}} 1000$ (Amersham Biosciences). O resultado do seqüenciamento foi comparado manualmente com a sequência padrão obtidas dos bancos de dados genômicos (GenBank, do Genome Browser - UCSC- http://genome.ucsc.edu/).

As soluções dos primers dos genes SHH, ZRS, WNT7a, WNT10b e GREM1 foram gentilmente cedidas pelo Dr. Bernd Wollnik, Instituto de Genética Humana, Universidade de Colônia, Alemanha. 
Tabela 3: Sequência dos primers utilizados para sequenciar genes candidatos.

\begin{tabular}{|c|c|}
\hline Primers & Sequências \\
\hline SHH_Primer_exon1F & CCATTCCAGCCCCTGTCTG \\
\hline SHH_Primer_exon1R & GGAAGTGGTCGGCTTCTCGT \\
\hline SHH_Primer_exon2F & CTAACGTGTCCGTCGGTGG \\
\hline SHH_Primer_exon2R & TCTTGAATCAAGCCGAGGTG \\
\hline SHH_Primer_exon3F & CCAGCGTGCGCCCTCCTC \\
\hline SHH_Primer_exon3R & CTTAGGGTCACGCTGTGCAC \\
\hline SHH_Primer_exon4F & GTGCACAGCGTGACCCTAAG \\
\hline SHH_Primer_exon4R & TAGAGTCTACTTTGGACTG \\
\hline ZRS_Primer_exon1F & CTGGCCAGTGTTTAAATGGT \\
\hline ZRS_Primer_exon1R & TGATCCATAACCATTTCTAAG \\
\hline WNT̄10b_Primer_exon1F & CTATTCCTGAACCCGCATC \\
\hline WNT10b_Primer_exon1R & ССТСТСАААСТСТААССАGGC \\
\hline WNT10b_Primer_exon2F & TTCTTTCTGCСТCCACACTC \\
\hline WNT10b_Primer_exon2R & ССТСТСАААСТСТАACСAGGC \\
\hline WNT10b_Primer_exon3F & CTGTGCCTCTGTGTTCTGTC \\
\hline WNT10b_Primer_exon3R & AGAGCAAAGGGCTGAAAAG \\
\hline WNT7a_Primer_exon1F & CGTCTCGCACACTTGCAC \\
\hline WNT7a_Primer_exon1R & GCCTCTCAGAGAAGCTGTGG \\
\hline WNT7a_Primer_exon2F & TCGAATGGACATGAGTTAGGG \\
\hline WNT7a_Primer_exon2R & AATGCAAGTCAATGCACCTG \\
\hline WNT7a_Primer_exon3F & GGGTACTCAGTCGAGCTTTG \\
\hline WNT7a_Primer_exon3R & AGCACCAAGCAGAATGAGG \\
\hline WNT7a_Primer_exon4F & AGGGCCTAGAATCCAGGTC \\
\hline WNT7a_Primer_exon4R & GCAGGAAACCCAGGAAAAG \\
\hline GREM1_Primer_exon1F & TGCGTTTAAATGCTAGGTGC \\
\hline GREM1_Primer_exon1R & AACAGAAGCGGTTGATGATG \\
\hline GREM1_Primer_exon2F & AAGAGGCCCTGCATGTG \\
\hline GREM1_Primer_exon2R & CTGGTTGTTTTAGGTCTGGG \\
\hline Primer $\overline{1 F}$ _gene $\mathbf{Y W H A E}$ & TTGCCATAGAGCTGAGCAGT \\
\hline Primer 1R_gene YWHAE & AGAGGGTCCGAGAATTCCA \\
\hline Primer 2F_gene YWHAE & TTTCGCAGTAGCTTGACAGAA \\
\hline Primer 2R_gene YWHAE & CAGGCACAAAGATCAATATCAGA \\
\hline Primer 3F_gene YWHAE & GCTCTCTACCTCAAAACCAGAGA \\
\hline Primer 3R_gene YWHAE & AAAAGGACCAACTTTCAATCTTACA \\
\hline Primer 4F gene YWHAE & GCTTATTTTCCTTTAAAAATCGTTCC \\
\hline Primer 4R_gene YWHAE & ACAGGCCCAAGAAACAACAC \\
\hline Primer 5F_gene YWHAE & AAAGATTGCTGTCTAGCATGTCA \\
\hline Primer 5R_gene YWHAE & CGACAAGCCAAGGAATGTCTA \\
\hline Primer 6F_gene YWHAE & TGGCTGCCATAGCCTAATGT \\
\hline Primer 6R_gene YWHAE & TCTCTTAGATGCTTGCATCACC \\
\hline Primer 7F_gene YWHAE & AACAGGACTACATAGAGGCTTTTTC \\
\hline Primer $7 \mathrm{R}$ _gene YWHAE & TGGCTCCAGTCAGATATCCA \\
\hline Primer $8 \mathrm{~F}$ _gene YWHAE & TGGTATGGAAAAGCCTGCAT \\
\hline
\end{tabular}




\begin{tabular}{|c|c|}
\hline Primer 8R_gene YWHAE & GACATTCAGCCTTATTTGGTTGT \\
\hline Primer 1F_gene TUSC5 & ACACAGCCTCCCTGACTGAG \\
\hline Primer $1 R$ _gene TUSC5 & TCTCTGCCTTGGTGAGGAGT \\
\hline Primer 2F_gene TUSC5 & CTCCAGAGCCCCTTGTCC \\
\hline Primer $2 R$ _gene TUSC5 & GGAAAGGAGTCTTCCCCAAG \\
\hline Primer 3F_gene TUSC5 & AAGCTGACCCACAGCCTTC \\
\hline Primer 3R_gene TUSC5 & CTTGAGCAGTCCTCACACCA \\
\hline Primer 4F_gene TUSC5 & CCAGTGTTCTGAGCCCTGTT \\
\hline Primer 4R_gene TUSC5 & CCTCATTCATCCTGGCAGTT \\
\hline Primer 5F_gene TUSC5 & CACAATTTCCTGGGTTCCAC \\
\hline Primer 5R_gene TUSC5 & AAGCTGACAGGTGTGGGAAG \\
\hline Primer 6F_gene TUSC5 & GAGAGGCGTGTCTGTGAAGA \\
\hline Primer 6R_gene TUSC5 & TCAGGACGGTCAAACAACAG \\
\hline Primer 7F_gene TUSC5 & AAAGGGTCCCAGGCTGTC \\
\hline Primer $7 \mathrm{R}$ _gene TUSC5 & ATGGGACAAAGGATGCTGAC \\
\hline Primer 8F_gene TUSC5 & CACCTCACAGCCAGAGTCAA \\
\hline Primer 8R_gene TUSC5 & CCCCTGTGTGACGTGACTT \\
\hline Primer 9F_gene TUSC5 & GGGTGTGAGCACGGAGTATT \\
\hline Primer $9 R$ _gene TUSC5 & CTCTGAGCTCTGTCCCTGGT \\
\hline Primer 10F_gene TUSC5 & GCAGGCGAGGATAACTTGAG \\
\hline Primer 10R_gene TUSC5 & ATTGTTTGGAACCCCCTTG \\
\hline Primer 1F gene SERPINF1 & TAGGCGTAATGGATGGTGGT \\
\hline Primer 1R_gene SERPINF1 & TTCTGCTCCCTGGAGTGC \\
\hline Primer 2F gene SERPINF1 & GGGTGGGGGAAAGTGACTA \\
\hline Primer $2 R$ _gene SERPINF1 & GGTTCCCTGTCCTGTTTCC \\
\hline Primer 3F gene SERPINF1 & ACCACCACCCTACACAAAGC \\
\hline Primer 3R_gene SERPINF1 & CCCTCGCTGAACTGAAATG \\
\hline Primer 4F gene SERPINF1 & CCTACTTGGGCTCTCAGCAG \\
\hline Primer 4R_gene SERPINF1 & TTTTGAGACGGAGTCTCGCT \\
\hline Primer 5F gene SERPINF1 & GCTGAGCGCTAAACCAGAA \\
\hline Primer 5R_gene SERPINF1 & TGCACTCCAGTTAGGACTACAGA \\
\hline Primer 6F gene SERPINF1 & CAGAGCCCCTGACAGCTAAG \\
\hline Primer 6R_gene SERPINF1 & GCTGTCGGATCTCAAAGGTC \\
\hline Primer 7F _gene SERPINF1 & GCTCCTGGCTGTGTCTGTC \\
\hline Primer 7R_gene SERPINF1 & TGCGTTCTGCTTAGCACAGT \\
\hline Primer 8F gene SERPINF1 & ATCCCTTGGTTGGGGTGT \\
\hline Primer 8R _gene SERPINF1 & ACGGTGACTTCCTGCAGTGT \\
\hline Primer 1F_gene RTN4RL1 & CCAGGGATTTGAATCTGGAC \\
\hline Primer 1R_gene RTN4RL1 & GGGGCTACTTCCCAGACC \\
\hline Primer 2F_gene RTN4RL1 & CTCAGCCAAGACGAGGATG \\
\hline Primer 2R_gene RTN4RL1 & CTGGGGTGGATGTAGGTGAT \\
\hline Primer 3F_gene RTN4RL1 & CACCCTGTGGATCTACTCGAA \\
\hline Primer 3R_gene RTN4RL1 & CCCAGACTCCACAGCTTGTT \\
\hline Primer 4F_gene RTN4RL1 & CTACCTGCAGGACAACCACA \\
\hline Primer 4R_gene RTN4RL1 & GGGACACACAGGGGACAG \\
\hline Primer 5F_gene RTN4RL1 & GAGTTCCTCCGCCTCAAC \\
\hline
\end{tabular}




\begin{tabular}{lc}
\hline Primer 5R_gene RTN4RL1 & CCCGCCTTAGAGATCTGATT \\
Primer 6F _gene RTN4RL1 & GAAGCCGGGGAAGAACTG \\
Primer 6R_gene RTN4RL1 & TTCCTTGGTGGACATGTGG \\
\hline
\end{tabular}

\subsubsection{Análise de lod scores}

Os resultados dos estudos de ligação foram analisados por meio do cálculo dos lod scores.

Os lod scores de dois pontos, isto é, um ponto considerado o marcador polimórfico e o outro gene da doença, foram calculados por meio dos programas MLINK e ILINK do pacote de programas FASTLINK 4.2 (Lathrop e col., 1985; Cottingham e col., 1993), sendo o último utilizado para calcular o valor de lod score máximo e a fração de recombinação correspondente. As frequências dos alelos dos marcadores foram consideradas iguais a $1 / \mathrm{N}$, sendo $\mathrm{N}$ o número de alelos daquele marcador encontrado na família em questão. Os lod scores foram calculados utilizando-se frequência gênica do alelo mutado de 0,0001. Admitimos também que a taxa de recombinação é semelhante em ambos os sexos e que a taxa de mutação do gene é zero, visto que esses parâmetros não alteram os resultados finais.

Também foram calculados lod scores de múltiplos pontos. Os lod scores de múltiplos pontos (lod scores que resultam da analise da segregação de vários marcadores de um mesmo cromossomo simultaneamente em relação à doença) foram calculados utilizando-se o programa MERLIN (Abecasis e col.,2002). Os cálculos no programa MERLIN não apresentam limitações quanto ao número de microssatélites ou SNPs analisados em cada cromossomo e, portanto, permitem que todos os marcadores de um mesmo cromossomo sejam analisados simultaneamente. 


\subsubsection{PCR quantitativo}

Essa análise foi conduzida no laboratório do Dr. Stefan Mundlos e da Dra. Eva Klopocki, pesquisadores do Instituto de Genética Médica da Universidade Charité (BerlimAlemanha), em colaboração com o nosso grupo de pesquisa.

Como o grupo alemão havia identificado uma duplicação genômica em amostras de paciente da família 1 por nós cedida em estudo colaborativo, para refinarmos a localização da duplicação e estudar a segregação na família utilizamos a técnica de PCR quantitativo ("Real Time PCR").

Inicialmente, foram utilizados 10 pares de primers para estudo de uma região do cromossomo 17p13.3, que foram diluídos em $190 \mu 1$ de água (concentração final $100 \mathrm{pmol} / \mu \mathrm{l}$ ). Para cada reação preparou-se um mix contendo $6 \mu 1$ de SYBER-Green e $1 \mu 1$ do mix correspondente a cada par de primer. Utilizaram-se também primers que amplificam o gene da Albumina $(A L B)$ e para o gene $F 8$, presente no cromossomo $\mathrm{X}$, que serviram como controle da reação. Para um volume final de reação de $12 \mu 1$, contendo $2 \mathrm{ng} / \mu 1$ de DNA total, foram utilizados $7 \mu 1$ de Mix-SYBER-Green-Primer e $5 \mu 1$ de DNA. A reação de PCR quantitativo foi realizada no

equipamento $\mathrm{ABI}^{\mathrm{TM}}$ OpenArray ${ }^{\circledR}$ Real-Time PCR Instrument (Amersham Biosciences) e analisada no programa RQ Manage 1.2 (Amersham Biosciences).

Como as amostras dos indivíduos afetados apareceram duplicadas em relação ao segmento amplificado por 4 dos pares de primers utilizados e a distância entre o primeiro e último segmentos com resultados normais e o primeiro e último segmentos duplicados era razoavelmente grande (cerca de $20 \mathrm{~Kb}$ ), construíram-se mais 17 pares de primers (tabelas 4 e 5 ) nessa região para tentar restringir ainda mais a duplicação e localizar seus pontos de quebra distal e proximal. 
Tabela 4: Primers utilizados para definir a duplicação encontrada no cromossomo 17p13.3 por PCR quantitativo na região distal da duplicação.

\begin{tabular}{|c|c|}
\hline Primers & Sequências \\
\hline 17p13.3_R1_F & TCTGTTTCCTCATCACGCTG \\
\hline 17p13.3_R1_R & TGCACATGAGACCTTTGCTT \\
\hline 17p13.3_R2_F & AACAGTCGTTTTGGACCCAC \\
\hline 17p13.3_R2_R & AAGTGTCAATGAACGAGGGC \\
\hline 17p13.3_R3_F & TGCATTTCAAAAGAGGCAGA \\
\hline 17p13.3_R3_R & TCTGTCGTTAAAGAGCCCCT \\
\hline 17p13.3_R4_F & GCCAGGAAAACAAGCAGAAA \\
\hline 17p13.3_R4_R & AGGAAGGAAACTGCTCCCAC \\
\hline 17p13.3_R5_F & CGATGGTTTTGTTCCTTTGC \\
\hline 17p13.3_R5_R & GCAGACATCTCCACCCAGTT \\
\hline 17p13.3_R6_F & ACCCAGAAATGGTTGGAGGT \\
\hline 17p13.3_R6_R & CTCCCTTTGGTGACCTGTTC \\
\hline 17p13.3_R7_F & AGAACAAGTTGTCGGCAGGT \\
\hline 17p13.3_R7_R & CATGCACACATTTGGTCCTC \\
\hline 17p13.3_R8_F & CCATGGCTGGACCTTTGTAG \\
\hline 17p13.3_R8_R & GATGACAAAAAGGGGTGTCG \\
\hline 17p13.3_R9_F & GCAGATTTGGGGGACATAGA \\
\hline 17p13.3_R9_R & TCTGTGATTGTCTGCCTTGC \\
\hline
\end{tabular}

Tabela 5: Primers utilizados para definir a duplicação encontrada no cromossomo 17p13.3 por PCR quantitativo na região proximal da duplicação.

\begin{tabular}{|c|c|}
\hline Primers & Sequências \\
\hline 17p13.3_R10_F & GGACAAATAGACCGATGAGGA \\
\hline 17p13.3_R10_R & GCATGGTATGAGGGAGATGG \\
\hline 17p13.3_R11_F & ATGTCTCCACCAAAAGCAGC \\
\hline 17p13.3_R11_R & TTACCTCAGTGCCGTGACAG \\
\hline 17p13.3_R12_F & AGGGGTCACACCTTTATCCC \\
\hline 17p13.3_R12_R & CCCAAATTAGCTGCTTCCTG \\
\hline 17p13.3_R13_F & GGGAGACTGCTATCCTGCTG \\
\hline 17p13.3_R13_R & CTCCAGAGGCTAGTGGCAGT \\
\hline 17p13.3_R14_F & CTATGGCAGCCACAAACAAA \\
\hline 17p13.3_R14_R & TAGAAGTCCTTTGCCTGCGT \\
\hline 17p13.3_R15_F & AAGGTGGAACAGGCAGAGTC \\
\hline 17p13.3_R15_R & TTCCGCTTTCAGTTTTGGTT \\
\hline 17p13.3_R16_F & AAAACATGTCCCCAGAGGTG \\
\hline 17p13.3_R16_R & TGTTGATGGAGGGAAAGCAT \\
\hline 17p13.3_R17_F & CCACCACCACCAAATGTAAA \\
\hline 17p13.3_R17_R & GATTGTTGAACAGGGATGGAG \\
\hline
\end{tabular}




\subsubsection{Long Range PCR (PCR de longo alcance)}

Para tentar identificar os pontos de quebra da região duplicada foi realizada a amplificação de uma região com cerca de $15 \mathrm{~Kb}$ nos pacientes da família 1, utilizando-se uma polimerase específica (TaKaRa LA Taq $q^{\mathrm{TM}}$ - TAKARA BIO INC.) que amplifica grandes fragmentos de DNA. Para um volume final de reação de $50 \mu$, contendo $200 \mathrm{ng}$ de DNA total, foram utilizados 10pmoles de cada primer (17p13.3_R17_F e 17p13.3_R1_R do PCR quantitativo), 1U de TaKaRa LA Taq polimerase, 20mM LA PCR Buffer II (kit TaKaRa LA Taq ${ }^{\mathrm{TM}}$ - TAKARA BIO INC.) e 25mM de dNTP- Mixture. As condições da amplificação foram as seguintes: desnaturação inicial $94^{\circ} \mathrm{C}$ por 1 min, 2 ciclos de desnaturação a $94^{\circ} \mathrm{C}$ por 30 segundos, hibridação a $61^{\circ} \mathrm{C}$ por 30 segundos, extensão a $68^{\circ} \mathrm{C}$ por 15 minutos, 2 ciclos de desnaturação a $94^{\circ} \mathrm{C}$ por 30 segundos, hibridação a $59^{\circ} \mathrm{C}$ por 30 segundos, extensão a $68^{\circ} \mathrm{C}$ por 15 minutos, 2 ciclos de desnaturação a $94^{\circ} \mathrm{C}$ por 30 segundos, hibridação a $57^{\circ} \mathrm{C}$ por 30 segundos, extensão a $68^{\circ} \mathrm{C}$ por 15 minutos, 2 ciclos de desnaturação a $94^{\circ} \mathrm{C}$ por 30 segundos, hibridação a $55^{\circ} \mathrm{C}$ por 30 segundos, extensão a $68^{\circ} \mathrm{C}$ por 15 minutos e extensão final a $68^{\circ} \mathrm{C}$ por 10 minutos. Os produtos de PCR obtidos foram visualizados em gel de agarose a 1,5\% após coloração com brometo de etídeo. 


\section{Resultados e discussão}

\subsection{Família 1}

Durante o projeto de iniciação cientifica, o aluno Nelson Henderson Cotrim realizou estudos de ligação que permitiram excluir ligação com as regiões cromossômicas 6q21, 3q27, 7q21, 10q24, 19p13 e 4p15. Durante o projeto de doutoramento de Karina Lezirovitz (processo FAPESP número: 2003/04780-9) foram realizados estudos com marcadores moleculares do tipo microssatélites (varredura genômica com 382 marcadores). Por meio do estudo de ligação foi possível definir a região cromossômica $17 \mathrm{p} 13.3-17 \mathrm{p} 13$ como candidata a conter o gene responsável pela síndrome nessa família (Lezirovitz e col., 2008). Essa região está delimitada provavelmente pelos microssatélites D17S1529 e D17S831 (Figura 2 - página 35) e possui cerca de $3 \mathrm{cM}$ e $370 \mathrm{~Kb}$. Dentre os 21 genes existentes nessa região, por indicação do software "PosMed ${ }^{\mathrm{SM}}$, o gene $C R K$ foi selecionado para ser sequenciado em primeiro lugar (Ensemble 58: Maio 2010 - http://may2010.archive.ensembl.org/index.html). Os três exons do gene $C R K$ foram estudados ainda na vigência do doutorado de Lezirovitz, mas nenhuma mutação patogênica foi encontrada. $\mathrm{O}$ fato de termos uma região candidata com ainda 20 genes a serem estudados justificaram a continuação do projeto de identificação do gene responsável pela condição.

Dentre os 20 genes restantes existentes na região candidata 17p13.1-17p13.3 (após exclusão do gene $C R K$ ), por indicação do software "ENDEAVOUR", o gene RPAl foi selecionado para ser sequenciado. Os 17 exons do gene RPAl foram sequenciados e analisados, mas nenhuma mutação patogênica foi encontrada.

Um segundo gene, YWHAE, também indicado pelo mesmo software, foi selecionado como o segundo gene candidato a ser sequenciado. Esse gene apresenta splicing alternativo, com 
sete isoformas de RNAm diferentes. Entretanto, apenas uma delas resulta em um produto protéico. Todos os exons do gene foram sequenciados e nenhuma mutação foi detectada.

Como os softwares só indicaram esses três genes como principais candidatos, $(C R K$, RPA1 e YWHAE) realizou-se uma pesquisa no banco de dados de genoma de camundongos (MGI - Mouse Genome Informatics - http://www.informatics.jax.org/) à procura de possíveis genes relacionados a defeitos de membros, à procura de genes localizados no cromossomo murino correspondente ao cromossomo 17 humano e à procura de modelos animais knockout dos genes presentes na região candidata. Essas buscas não mostraram informações adicionais para a seleção do próximo gene a ser sequenciado. Escolheu-se aleatoriamente então como próximo gene a ser sequenciado o SERPINF1. Esse gene não apresenta splicing alternativo e possui apenas oito exons. Durante a análise das sequências do exon 1 observou-se a substituição de uma citosina por uma timina em heterozigose, em mais de um indivíduo afetado. Essa mutação não sinônima leva à substituição de uma treonina por uma metionina e, apesar de apresentar elevada taxa de heterozigose $(0,45)$ na população, já foi associada a algumas doenças como degeneração da mácula dependente da idade e ao diabetes (Iizuka e col.,2007; Lin e col.,2008). Para averiguar se essa mutação estava relacionada com a ectrodactilia foi realizado o sequenciamento de todos os indivíduos afetados. Essa substituição não foi encontrada em todos os afetados, indicando não estar relacionada à causa da doença. Os demais exons do SERPINF1 foram sequenciados, mas nenhuma outra mutação foi encontrada. O quinto gene selecionado, RTN4RL1, com seis exons, e o sexto gene selecionado, TUSC5 (gene supressor de tumor), com 3 exons, também foram sequenciados. Entretanto, nenhuma mutação foi encontrada.

Nessa época, o Dr. Stefan Mundlos, pesquisador do Instituto de Genética Médica da Universidade Charité e do Instituto Max Planck (Berlin-Alemanha) entrou em contato com o 
nosso grupo de pesquisa e manifestou interesse por estudo colaborativo, já que investigava mais três famílias (uma da Alemanha, uma de Oman e uma do EUA) com o mesmo fenótipo e com evidência de ligação com a mesma região do cromossomo 17 por nosso grupo mapeada. Em uma dessas três famílias (na dos Estados Unidos) havia sido detectada uma duplicação por meio de array-CGH e confirmada posteriormente por meio de PCR quantitativo. Enviamos material de dois afetados para o laboratório do Dr. Mundlos e o array-CGH lá realizado indicou duplicação provável de duas sondas. A hipótese inicial era a de que a duplicação poderia ter pelo menos 111.228 pb. A fim de testar a segregação da mesma duplicação no resto da família estudada pelo nosso grupo, levamos o material para o laboratório do Dr. Mundlos e, seguindo o protocolo sugerido, realizamos reações de PCR quantitativo com alguns primers da região $17 \mathrm{p} 13.3$, onde havia sido encontrada a mutação na família dos Estados Unidos. Inicialmente, o PCR quantitativo foi realizado com amostras dos indivíduos afetados V:4 e IV:7, com 10 pares de primers (Figura 10). Em ambos foi possível observar uma região duplicada que teria pelo menos $110.838 \mathrm{bp}$, entre o segmento amplificado pelo quinto par de primers e o oitavo par de primers como mostra a figura 10. 


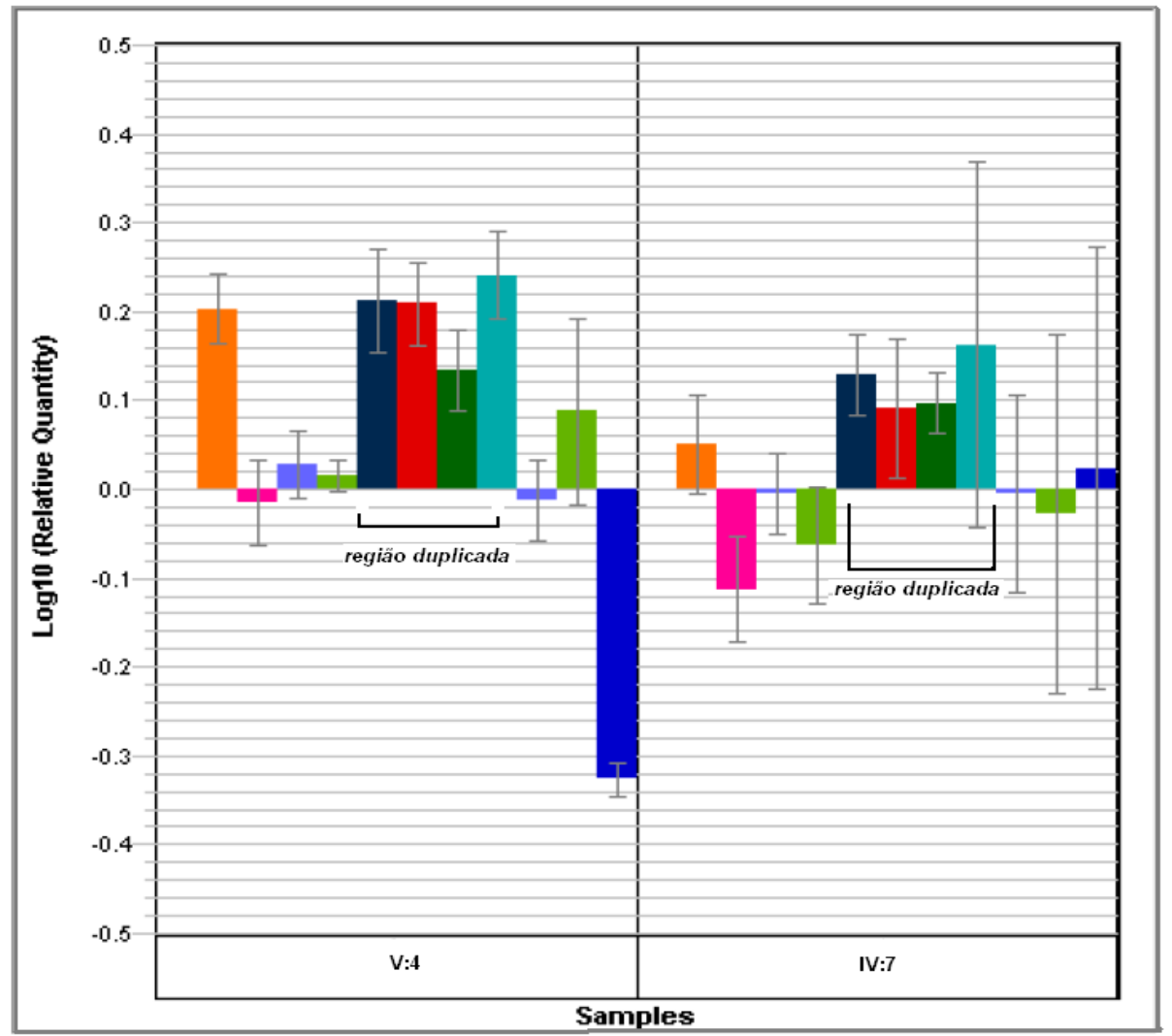

Figura:10. Gráfico mostrando o resultado da PCR quantitativa nos indivíduos V:4 e IV:7 e a região duplicada. Cada barra representa um amplicon diferente e eles estão dispostos na ordem 5'-3', da esquerda para a direita. A última barra representa o segmento amplificado do gene $F 8$, presente no cromossomo X, que funciona como controle da reação.

Para certificar que duplicação era a mutação que causava o fenótipo da doença, realizouse o PCR quantitativo em mais seis indivíduos da família (indivíduos V:6, V:5, III:3, IV:10, III:4 e IV:6). Dentre eles, dois eram afetados (V:6 e IV:10), um era portador certo do gene mutado (III:3) e três eram normais (III:4, V:5 e IV:6). A duplicação foi encontrada nos indivíduos afetados e no portador certo, enquanto que os indivíduos normais não apresentavam a mutação (figura 11). 


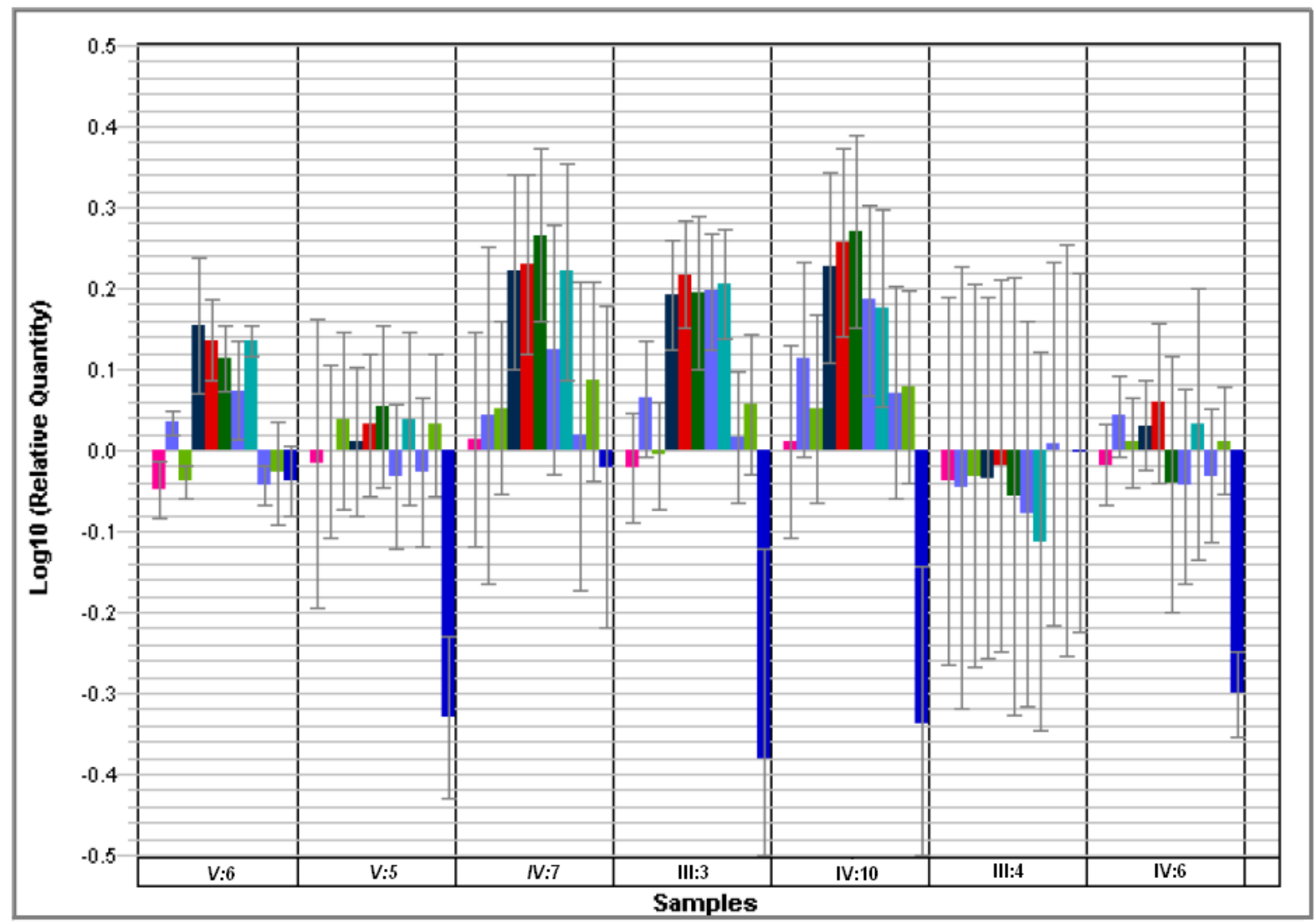

Figura 11. Gráfico mostrando o resultado da PCR quantitativa nos indivíduos V:6, V:5, IV:7, III:3, IV:10, III:4 e IV:6. Cada barra representa um amplicon diferente e eles estão dispostos na ordem 5'-3', da esquerda para a direita. A última barra representa o segmento amplificado do gene $F 8$, presente no cromossomo $\mathrm{X}$, que funciona como controle da reação.

De acordo com a descrição clínica realizada durante o pós-doutoramento da Dra. Sylvia Maestrelli, os indivíduos III:10, IV:20 e IV:25 apresentavam sinais clínicos, porém insuficientes para fechar o diagnóstico da síndrome apresentada. Portanto, não foram considerados afetados. Realizou-se PCR quantitativo também com amostras desses indivíduos a fim de identificar a possível duplicação. Além disso, a duplicação também foi testada no individuo V:3, que apresentava o haplótipo relacionado à doença em questão, mas não apresentava o fenótipo (Figura 12). Os demais indivíduos na figura, IV:26 e III:9, eram afetados e apresentaram a mutação. 


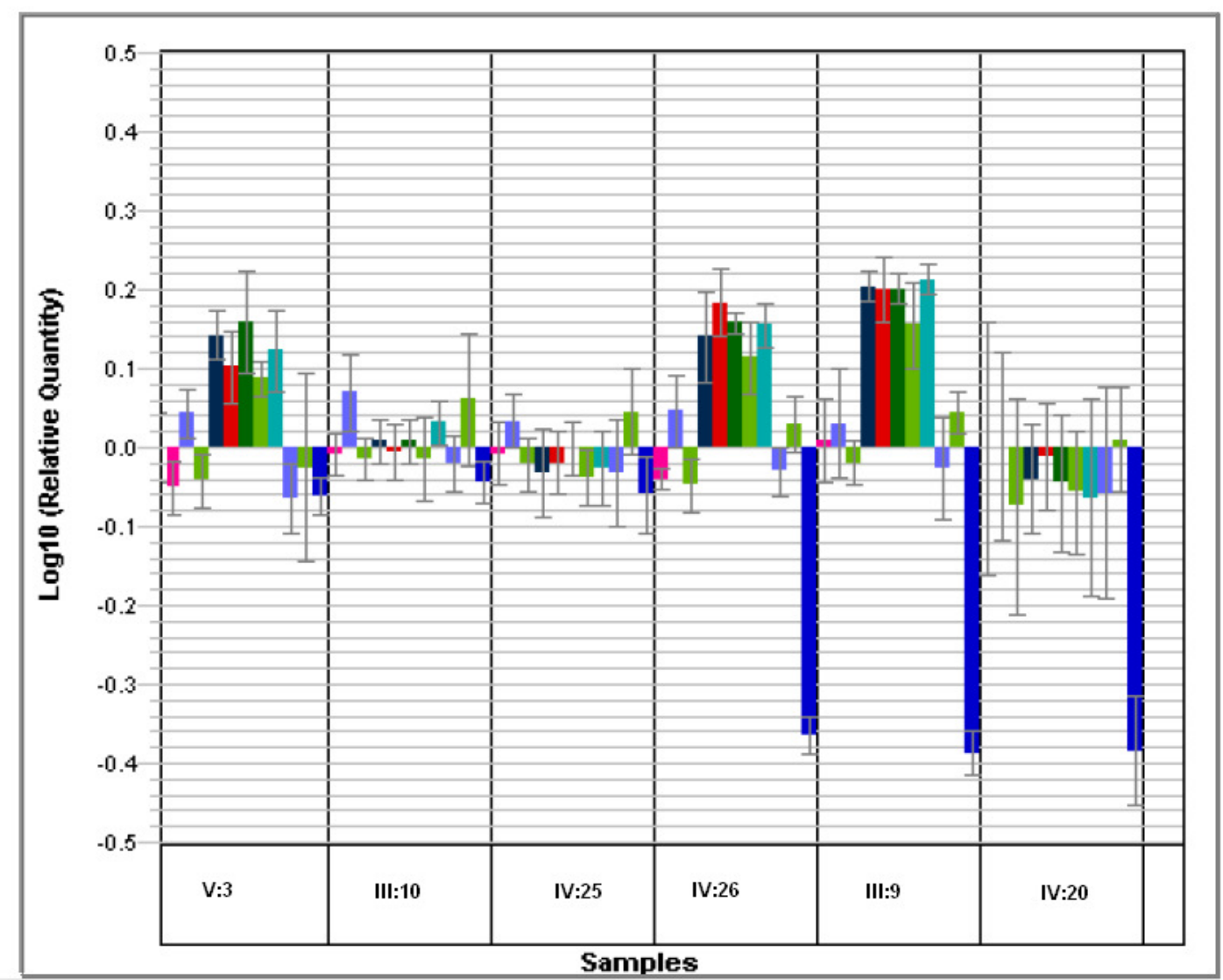

Figura 12. Gráfico mostrando o resultado da PCR quantitativa nos indivíduos V:3, III:9, III:10, IV:20, IV:25 e IV:26. Cada barra representa um amplicon diferente e eles estão dispostos na ordem 5'-3', da esquerda para a direita. A última barra representa o segmento amplificado do gene $F 8$, presente no cromossomo $\mathrm{X}$, que funciona como controle da reação.

Como se pode observar no gráfico, os indivíduos III:9 e IV:26 são afetados e possuem a duplicação na região 17p13.3, como esperado. O individuo V:3, que apesar de não apresentar o fenótipo da doença em questão, é portador da mutação de acordo com o previsto pela análise dos haplótipos, como mostra a figura 12. Já os indivíduos III:10, IV:20 e IV:25, que são indivíduos com sinais clínicos insuficientes, não são portadores da duplicação. Um resumo dos resultados está apresentado na Tabela 6. 
Tabela 6: Resumo dos resultados da PCR quantitativa.

\begin{tabular}{|c|c|c|}
\hline Registro & Quadro clínico & Duplicação \\
\hline III:3 & Portador certo & Presente \\
\hline III:4 & Normal & Ausente \\
\hline III:9 & Afetado & Presente \\
\hline III: 10 & Sinais clínicos insuficientes & Ausente \\
\hline IV:6 & Normal & Ausente \\
\hline IV:7 & Afetado & Presente \\
\hline IV:10 & Afetado & Presente \\
\hline IV:20 & Sinais clínicos insuficientes & Ausente \\
\hline IV:25 & Sinais clínicos insuficientes & Ausente \\
\hline IV:26 & Afetado & Presente \\
\hline $\mathrm{V}: 3$ & Normal & Presente \\
\hline $\mathrm{V}: 4$ & Afetado & Presente \\
\hline $\mathrm{V}: 5$ & Normal & Ausente \\
\hline $\mathrm{V}: 6$ & Afetado & Presente \\
\hline
\end{tabular}

Como o PCR quantitativo realizado no laboratório do Dr. Mundlos mostrou apenas 4 segmentos duplicados nos indivíduos afetados e o espaço entre os segmentos encontrados como duplicados pelo array e dos segmentos testados com resultados normais pelo PCR quantitativo era razoavelmente grande (cerca de $20 \mathrm{~Kb}$ ) construíram-se mais 17 pares de primers nessa região (9 primers para a região distal e 8 primers para a região proximal) para se tentar mapear mais 
precisamente a duplicação e localizar exatamente os pontos de quebra distal e proximal (Figura

13). Nesse experimento, utilizaram-se amostras de dois indivíduos afetados que possuem a mutação: indivíduos IV:7 e IV:10. Os resultados obtidos estão na figura 14.
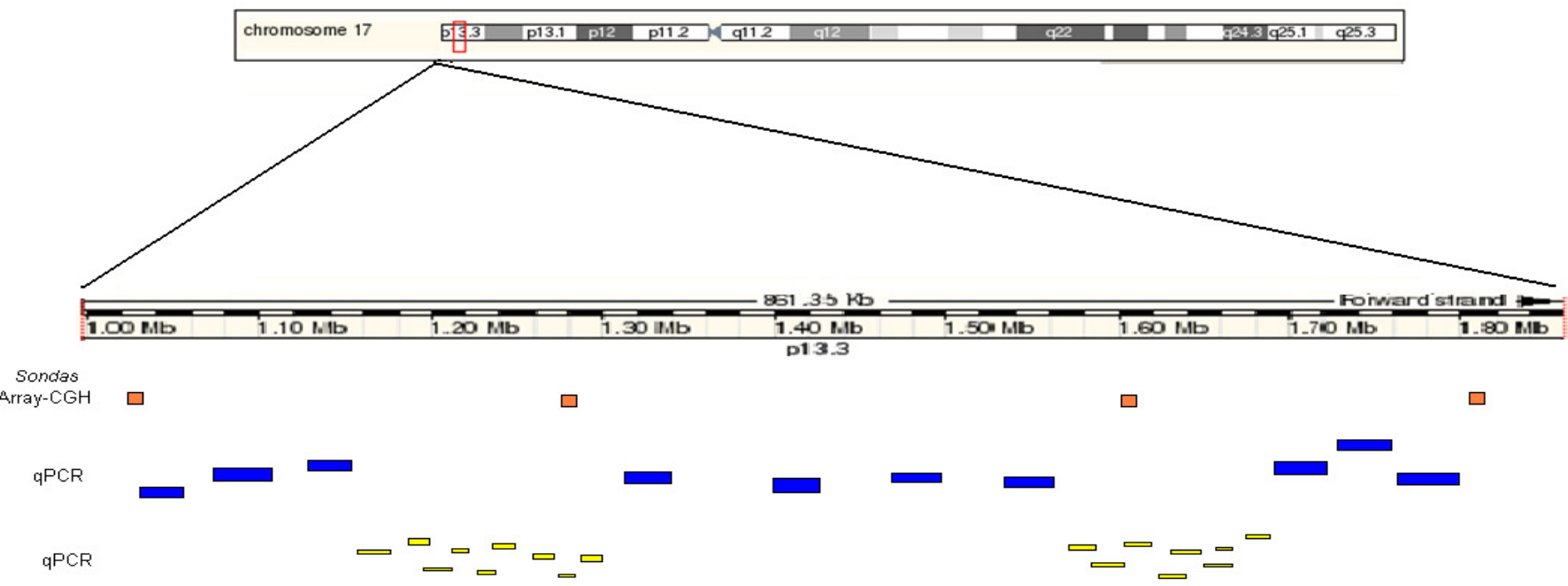

Duplicaçẫo Array-CGH

Figura 13. Esquema representando a estratégia de mapeamento da duplicação. Os retângulos laranjas representam a localização das sondas do array-CGH. Os retângulos azuis representam os amplicons da primeira etapa de PCR quantitativo (10 pares de primers). Os retângulos amarelos representam os amplicons da segunda etapa do PCR quantitativo (17 pares de primers). As barras em verde representam as regiões consideradas certamente duplicadas por cada técnica; as linhas tracejadas representam as possíveis regiões duplicadas como mapeadas por cada técnica. 


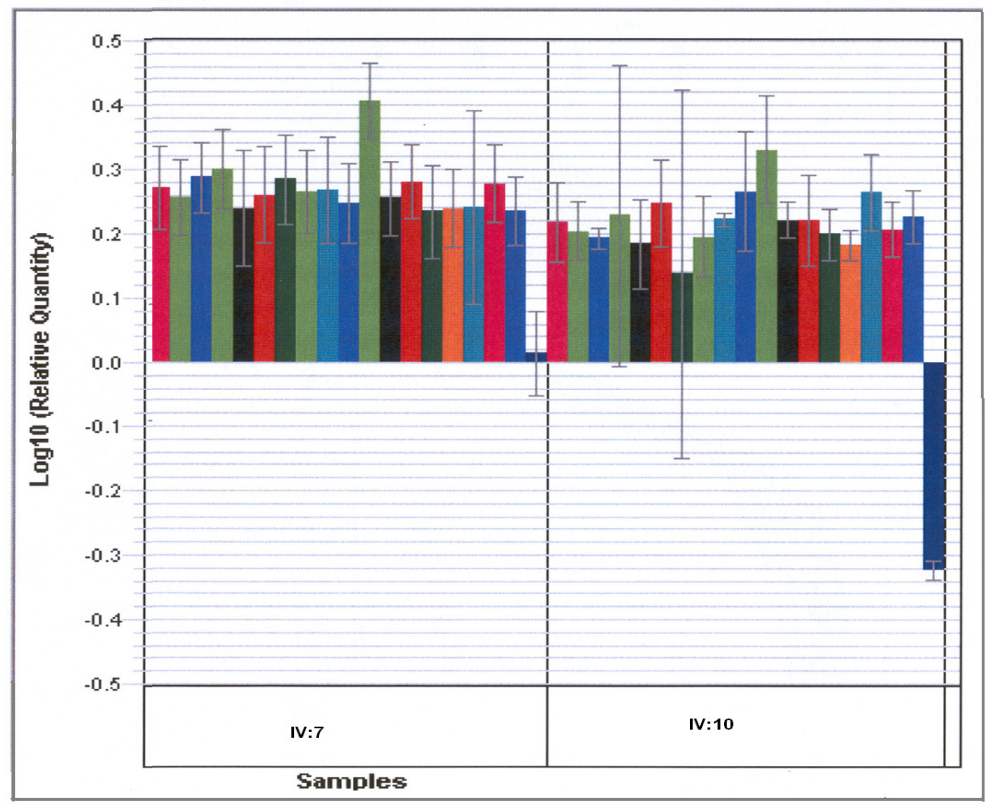

Figura 14. Gráfico mostrando o resultado da PCR quantitativa nos indivíduos IV:7 e IV:10. Cada barra representa um amplicon diferente e eles estão dispostos na ordem 5' $-3^{\prime}$, da esquerda para a direita. A primeira barra e a última barra representam o segmento amplificado do gene da $A L B$ e do gene $F 8$ que funcionam como controle da reação.

Como os 17 segmentos apareceram duplicados, tentou-se identificar os dois pontos de quebra por meio de sequenciamento do DNA. Para isso foi realizado um Long Range PCR, utilizando-se o primeiro primer reverse e o último primer forward dos 17 segmentos amplificados. Por meio dessa PCR conseguiu-se a amplificação de um fragmento de aproximadamente 5.000 bp apenas nos indivíduos afetados, confirmando a hipótese formulada de que a duplicação encontra-se em tandem, inserida diretamente e na mesma orientação ao lado da seqüência original, conforme indicado na figura 15 . 


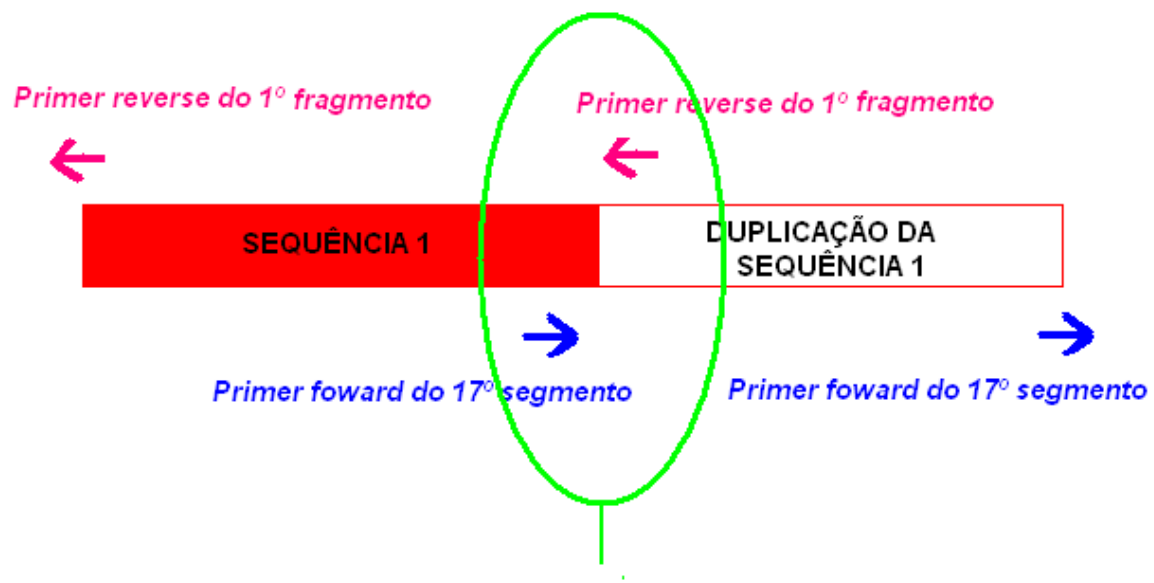

FRAGMENTO' DE $5000 \mathrm{pb}$

Figura 15. Esquema representando a estratégia de estudo do ponto de quebra da duplicação.

Desse modo, sequenciou-se o produto de PCR obtido nos indivíduos afetados até conseguir-se identificar os pontos de quebra. O ponto de quebra proximal está mostrado na figura 16, como exemplo.

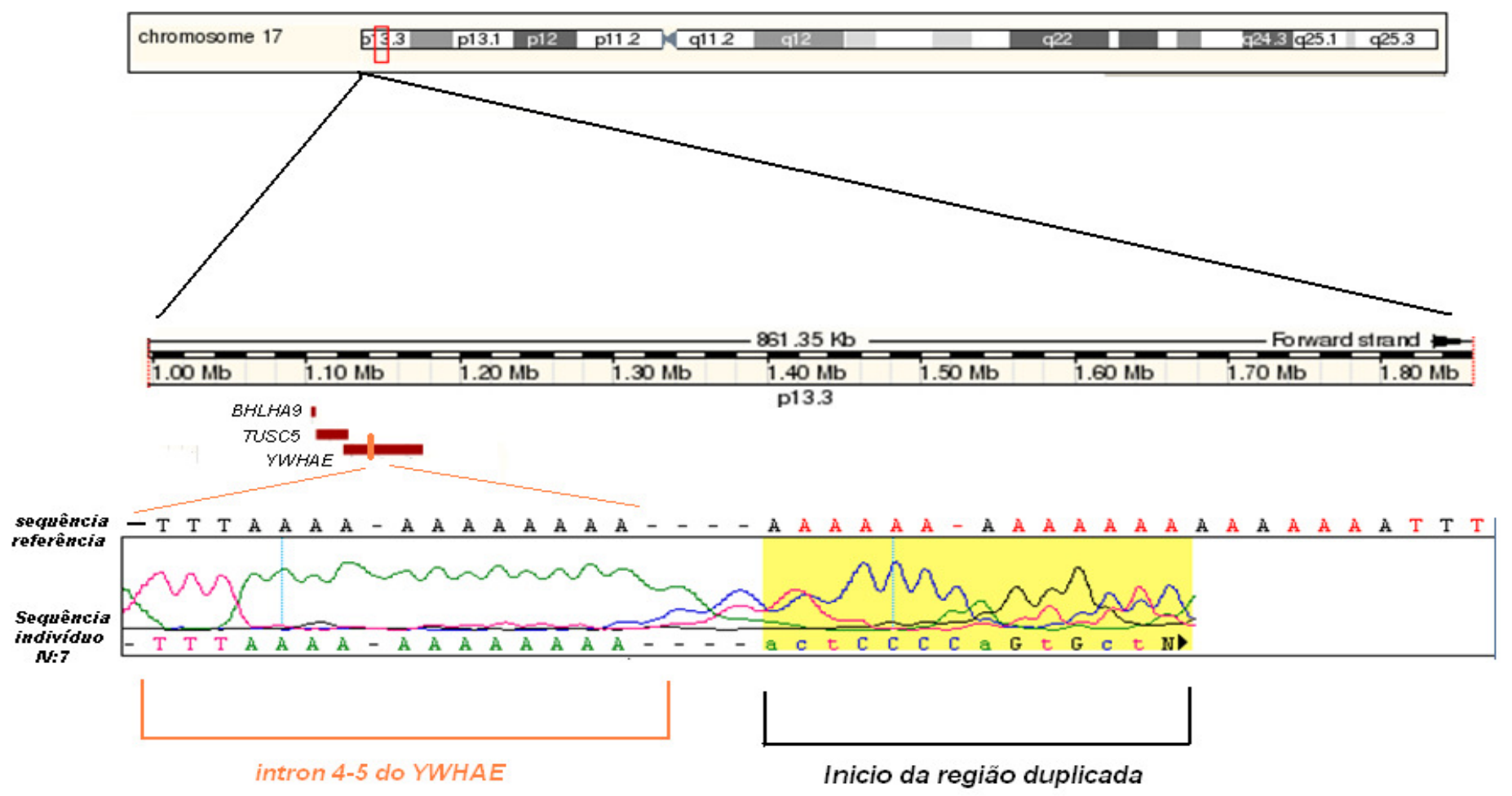

Figura 16. Reprodução de parte da sequência de referência da região 17p13.3 (Ensemble: 54: Maio 2009 - http://may2009.archive.ensembl.org/index.html) em comparação com a sequência do individuo afetado IV:7, mostrando o local exato do ponto de quebra proximal da duplicação, localizado no intron 4-5 do gene YWHAE (a sequência foi analisada no programa Sequencers). 
O ponto de quebra proximal do cromossomo 17 foi localizado na posição 12051721205173, enquanto que o ponto de quebra distal foi localizado na posição 1091097-1091098 (Figura 17). A duplicação tem cerca de $114 \mathrm{~Kb}$ e inclui três genes: BHLHA9, TUSC5 e YWHAE. O gene BHLHA9 e o gene TUSC5 estão presentes em três cópias, enquanto que o gene $Y W H A E$ é interrompido pela duplicação no intron 4-5 e, portanto, está parcialmente duplicado.

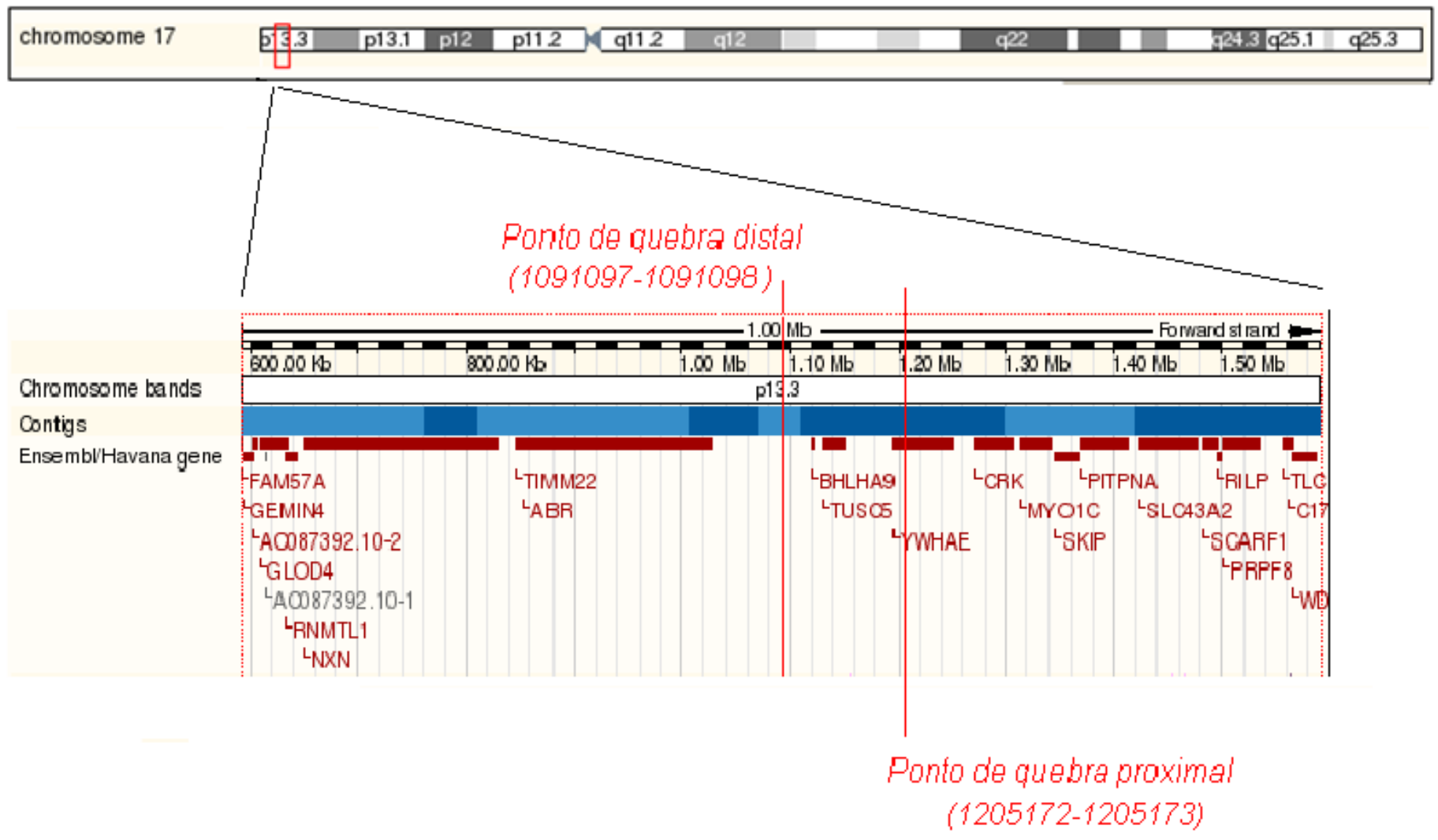

Figura 17. Esquema mostrando a localização dos pontos de quebra distal e proximal na região $17 \mathrm{p} 13.3$ (Ensemble: 54: Maio 2009 - http://may2009.archive.ensembl.org/index.html). 
A proteína 14-3-3 épsilon é uma oxigenase codificada pelo gene YWHAE, altamente conservada em plantas e mamíferos. Ela interage com algumas proteínas importantes como a CDC25 fosfatases, RAF1 e IRS1, sugerindo seu papel em diversas atividades relacionadas com a bioquímica de transdução de sinais, tais como a divisão celular, apoptose e a regulação da sensibilidade à insulina. Também já foi relacionada à origem da esquizofrenia (Masashi e col., 2008). Estudos recentes identificaram um novo mecanismo de supressão da sinalização de Hedgehog por meio da interação entre as proteínas da família Gli com a proteína 14-3-3 epsilon codificada pelo gene YWHAE (Yoshinari e col.,2010). Os resultados obtidos indicam que pode haver duas cópias normais do gene $Y W H A E$ e uma cópia que está sendo interrompida pela duplicação, alterando o intron 4-5 do gene. Essa interrupção leva a uma possível alteração no sitio de splicing do exon 5, gerando um novo transcrito diferente do original. É provável que tal transcrito contenha códons de parada prematuros e seja submetido a NMD (nonsense-mediateddecay). Resta, no entanto, a possibilidade de que uma proteína alterada seja produzida. Essa proteína mutada poderia interferir na regulação negativa do gene $S H H$ (sonic hedgehog), o que poderia explicar o fenótipo da doença em questão. Microdeleções e microduplicações no gene YWHAE já foram associadas e encontradas em pacientes com fenótipos diversos como: retardo mental, dismorfismo facial e atraso no desenvolvimento (Bruno e col., 2010; $\underline{\text { Mignon-Ravix e }}$ col.,2010 e Nagamani e col.,2010), mas ele nunca foi associado a defeito de membros. Todas essas microdeleções e microduplicações incluem alterações no gene $Y W H A E$ e em outros genes vizinhos, como o TUSC5 e CRK.

O gene TUSC5 é um gene supressor de tumor muito conhecido por estar altamente expresso em células adiposas cancerosas (Shibata e col., 2007; Koide e col., 2007; Oort e col., 2007; Oort e col., 2008; Knotts e col., 2009). Já foi relacionado a pequenas deleções e 
duplicações no cromossomo 17, incluindo outros genes como o YWHAE e o $C R K$, como mencionado anteriormente. Nunca foram encontradas mutações relacionadas diretamente a defeitos de membros. Entretanto, não podemos descartar que por estar presente em três cópias nos pacientes afetados, ele possa estar sendo super-expresso e influenciando a expressão de outros genes relacionados à formação dos membros, inibindo ou aumentando sua expressão.

O gene BHLHA9 é um gene muito conservado entre chimpanzés, camundongos e ratos (Stevens e col., 2008). Ele pertence a uma família de proteínas formadas por duas $\alpha$-hélices unidas por uma alça, ou loop. O produto do BHLHA9 possui duas funções muito importantes: a primeira está relacionada com a interação direta com a cromatina e a segunda está relacionada a um papel de regulação de transcrição. Ele interage com sequências promotoras ou enhancers (acentuadores) de outros genes (http://amigo.geneontology.org/).

Uma análise genômica usando microarrays de expressão para quatro tipos diferentes de células de camundongo (células de Sertoli, Schwann, timo e músculo) foi realizado a partir de células indiferenciadas. Os pesquisadores utilizaram células indiferenciadas e estimularam sua diferenciação nesses quatro tipos diferentes de células e durante esse processo analisaram seu padrão de expressão. Em todas as células estudadas e considerando-se todos os membros conhecidos da família $b H L H$, pode-se concluir que os genes $b H L H$, inclusive o BHLHA9, estão potencialmente envolvidos na diferenciação celular inicial (Stevens e col., (2008). O gene BHLHA9 é o único gene encontrado como duplicado em comum em todas as alterações presentes nas demais famílias estudadas pelo grupo do Dr. Mundlos (6 famílias) e, portanto, é considerado o melhor gene candidato a explicar os defeitos de membros (Klopocki, comunicação pessoal., 2010). O grupo do Dr. Mundlos está estudando a expressão de bhlha9 em embriões de camundongos e as analíses têm mostrado sua expressão na crista ectodermica apical (AER) 
durante o desenvolvimento do membro. A cópia extra do BHLHA9 pode levar a um excesso de produto que pode estar perturbando o desenvolvimento da AER e, portanto, levando ao desenvolvimento das mãos/pés anormais. Desses estudos, deve resultar uma publicação em colaboração.

\subsection{Família 2}

A revisão bibliográfica sobre aplasia/hipoplasia fibular indicou que não há nenhuma síndrome que se assemelhe com a presente nessa família, o que indica se tratar de síndrome nova (Santos e col., 2008). Outro aspecto que também motivou o desenvolvimento do estudo nessa família é que, até o momento, apenas dois genes foram identificados como sendo responsáveis pela aplasia/hipolasia fibular: o GDF5 (Douzgou e col.,2008) localizado na região 20q11 (fator 5 de diferenciação/crescimento) e o TBX3 (Borozdin e col.,2006), localizado na região 12q24, relacionados em síndromes bem distintas entre si e distintas dessa apresentada pela família 2. A disponibilidade de material dessa família com seis afetados, o fato de estarmos trabalhando com uma síndrome nunca descrita e a possibilidade de encontrar novos genes ou regiões cromossômicas associadas a defeitos de membros justificaram o desenvolvimento do projeto.

Os estudos moleculares nessa família tiveram início com a realização de estudos de ligação utilizando marcadores moleculares do tipo microssatélites mapeados nas regiões cromossômicas 10q24, 7q21, 17p13, 3q27 e 2q31, algumas das regiões descritas até o momento como regiões candidatas a conter genes responsáveis por defeitos de membros.

Estudos de ligação com a região 10q24 foram utilizados com cinco marcadores moleculares que flanqueiam essa região: D10S192, D10S185, D10S1686, D10S1693 e D10S597. Com os genótipos correspondentes a esses marcadores construímos os haplótipos da região 
cromossômica em questão (Figura 18). Como já foi dito anteriormente, o padrão de herança da doença nessa família ainda não foi estabelecido e, portanto, foram calculados os lod scores tanto na hipótese de padrão de herança autossômica dominante e penetrância incompleta quanto no caso de padrão de herança autossômico recessivo, o que não pode ser descartado completamente devido à grande quantidade de casamentos consanguíneos. Para a hipótese de herança dominante, utilizou-se o valor de penetrância $\mathrm{K}=0,324$ calculado a partir da genealogia, com exatos $95 \%$ de confiabilidade em um intervalo de 0,139 a 0,585 .

Os lod scores de dois pontos, isto é, um ponto considerado o marcador polimórfico e o outro gene da doença foram calculados com o auxilio dos programas MLINK e ILINK do pacote de programas FASTLINK 4.2 (Tabela 7). Realizou-se o cálculo de lod scores de múltiplos pontos com o auxílio do programa Merlin. O resultado da análise de múltiplos pontos está apresentado na Figura 19. 


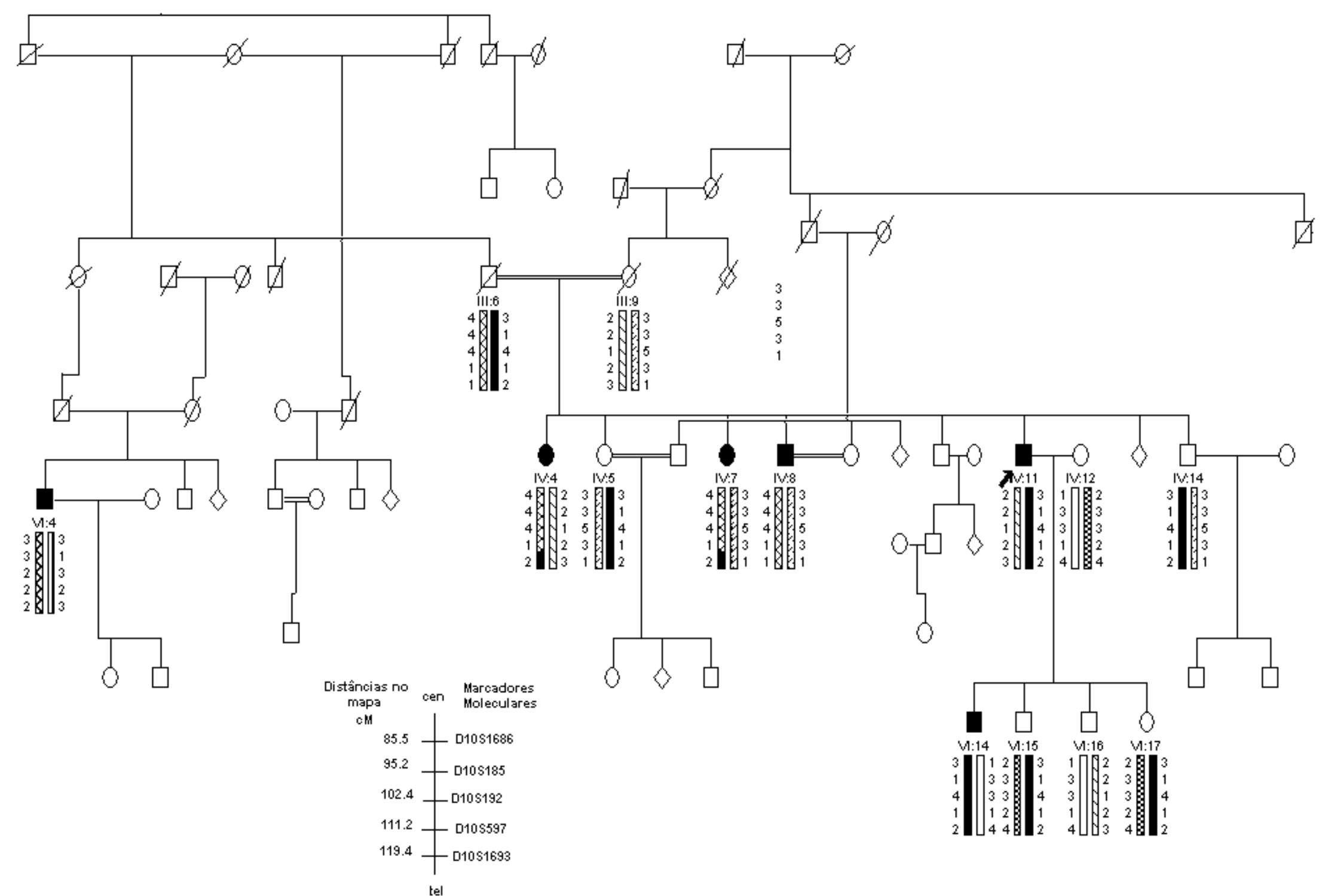

Figura 18. Heredograma da família 2 mostrando os haplótipos da região cromossômica 10q24.Os indivíduos assinalados em preto são afetados por um quadro clínico variado de malformações de mãos e pés, incluindo aplasia/hipoplasia fibular. 
Tabela 7: Lod scores de dois pontos calculados com o programa MLINK do pacote FASTLINK em relação aos microssatélites da região cromossômica 10q24. O dois modelos de herança autossômica foram utilizados para a realização do calculo. (A) Herança autossômica dominante e (B) Herança autossômica recessiva

(A)

\begin{tabular}{|l|l|l|l|l|l|l|l|}
\cline { 2 - 8 } \multicolumn{1}{c|}{} & \multicolumn{7}{c|}{ Frações de recombinação } \\
\hline Microssatélites & $\mathbf{0 , 0 0}$ & $\mathbf{0 , 0 1}$ & $\mathbf{0 , 0 5}$ & $\mathbf{0 , 1}$ & $\mathbf{0 , 2}$ & $\mathbf{0 , 3}$ & $\mathbf{0 , 4}$ \\
\hline D10S1686 & -3.39 & -1.07 & -0.44 & -0.22 & -0.08 & -0.03 & -0.01 \\
\hline D10S185 & -3.39 & -1.07 & -0.44 & -0.22 & -0.08 & -0.03 & -0.01 \\
\hline D10S192 & -0.11 & -0.11 & -0.12 & -0.12 & -0.10 & -0.06 & -0.02 \\
\hline D10S597 & -0.00 & -0.00 & -0.02 & -0.04 & -0.05 & -0.04 & -0.01 \\
\hline D10S1693 & -3.16 & -1.39 & -0.74 & -0.48 & -0.23 & -0.10 & -0.03 \\
\hline
\end{tabular}

(B)

\begin{tabular}{|l|l|l|l|l|l|l|l|}
\cline { 2 - 8 } \multicolumn{1}{c|}{} & \multicolumn{7}{c|}{ Frações de recombinação } \\
\hline Microssatélites & $\mathbf{0 , 0 0}$ & $\mathbf{0 , 0 1}$ & $\mathbf{0 , 0 5}$ & $\mathbf{0 , 1}$ & $\mathbf{0 , 2}$ & $\mathbf{0 , 3}$ & $\mathbf{0 , 4}$ \\
\hline D10S1686 & -infini & -4.78 & -2.14 & -1.14 & -0.36 & -0.09 & -0.01 \\
\hline D10S185 & -infini & -3.67 & -1.68 & -0.91 & -0.30 & -0.08 & -0.01 \\
\hline D10S192 & -infini & -2.76 & -1.41 & -0.86 & -0.37 & -0.14 & -0.03 \\
\hline D10S597 & -infini & -2.76 & -1.41 & -0.86 & -0.37 & -0.14 & -0.03 \\
\hline D10S1693 & -infini & -3.97 & -1.99 & -1.22 & -0.55 & -0.23 & -0.05 \\
\hline
\end{tabular}

Parametric Analysis for Dominant_Model

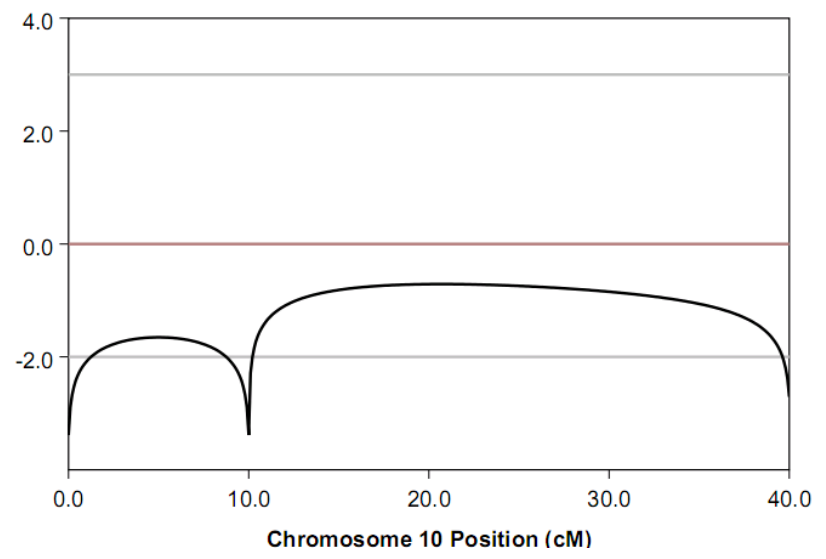

Parametric Analysis for Recessive_Model

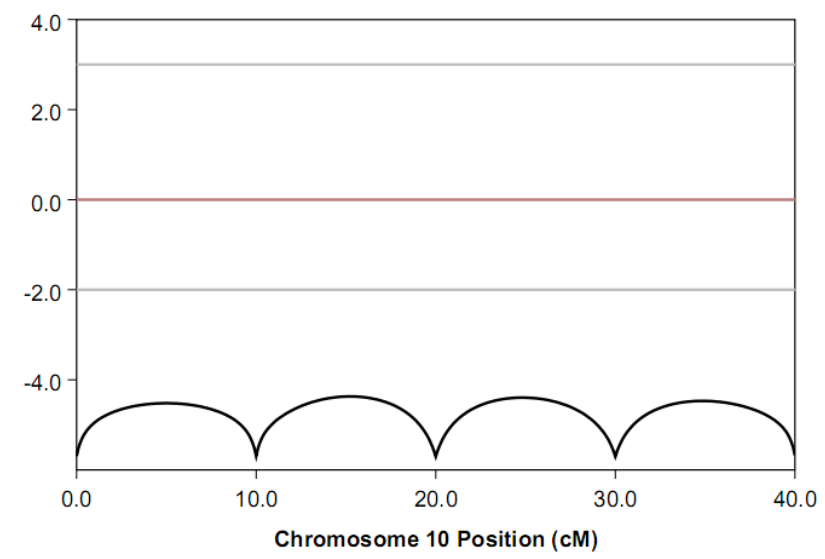

Figura 19. Resultados de lod scores de múltiplos pontos obtidos com os marcadores da região 10q24, utilizando os dois modelos de herança autossômica. 
A análise dos microssatélites próximo ao locos SHFM3 (região cromossômica 10q24) não mostrou evidência de ligação, considerando-se a segregação dos haplótipos e os valores negativos dos lod scores obtidos nas análises paramétricas. Em ambos os modelos de herança os resultados não revelaram lod scores significativos. Desse modo, a região 10q24 é improvável como candidata a conter o gene responsável pela doença em questão. Esses resultados já foram incluídos na publicação de Santos e col., (2008).

$\mathrm{O}$ mesmo procedimento foi realizado para as regiões candidatas $17 \mathrm{p} 13,7 \mathrm{q} 21,3 \mathrm{q} 27 \mathrm{e}$ 2q31. Para a procura de evidências de ligação com a região $17 \mathrm{p} 13.3-17 \mathrm{p} 13$, foram utilizados cinco marcadores moleculares que flanqueiam essa região (D17S849, D17S831, D17S938 e D17S1852). Para a região 7q21, foram utilizados 3 marcadores (D7S657, D7S515 e D7S486), para a região 3q27 foram utilizados 4 marcadores (D3S1565, D3S1262, D3S1580 e D3S1601) e para a região 2q31 foram utilizados 5 marcadores (D2S151, D2S142, D2S335, D2S364, D2S117).

Com os genótipos correspondentes a esses marcadores construímos os haplótipos das quatro regiões cromossômicas em questão (Figuras 20, 21, 22 e 23). Os lod scores de dois pontos foram calculados e estão apresentados nas Tabelas 8, 9, 10 e 11. Realizou-se o cálculo de lod scores de múltiplos pontos com o auxílio do programa Merlin. O resultado da análise de múltiplos pontos para as quatro regiões candidatas (17p13.3-17p13, 7q21, 3q27 e 2q31) está apresentado nas Figuras 24, 25, 26 e 27. 


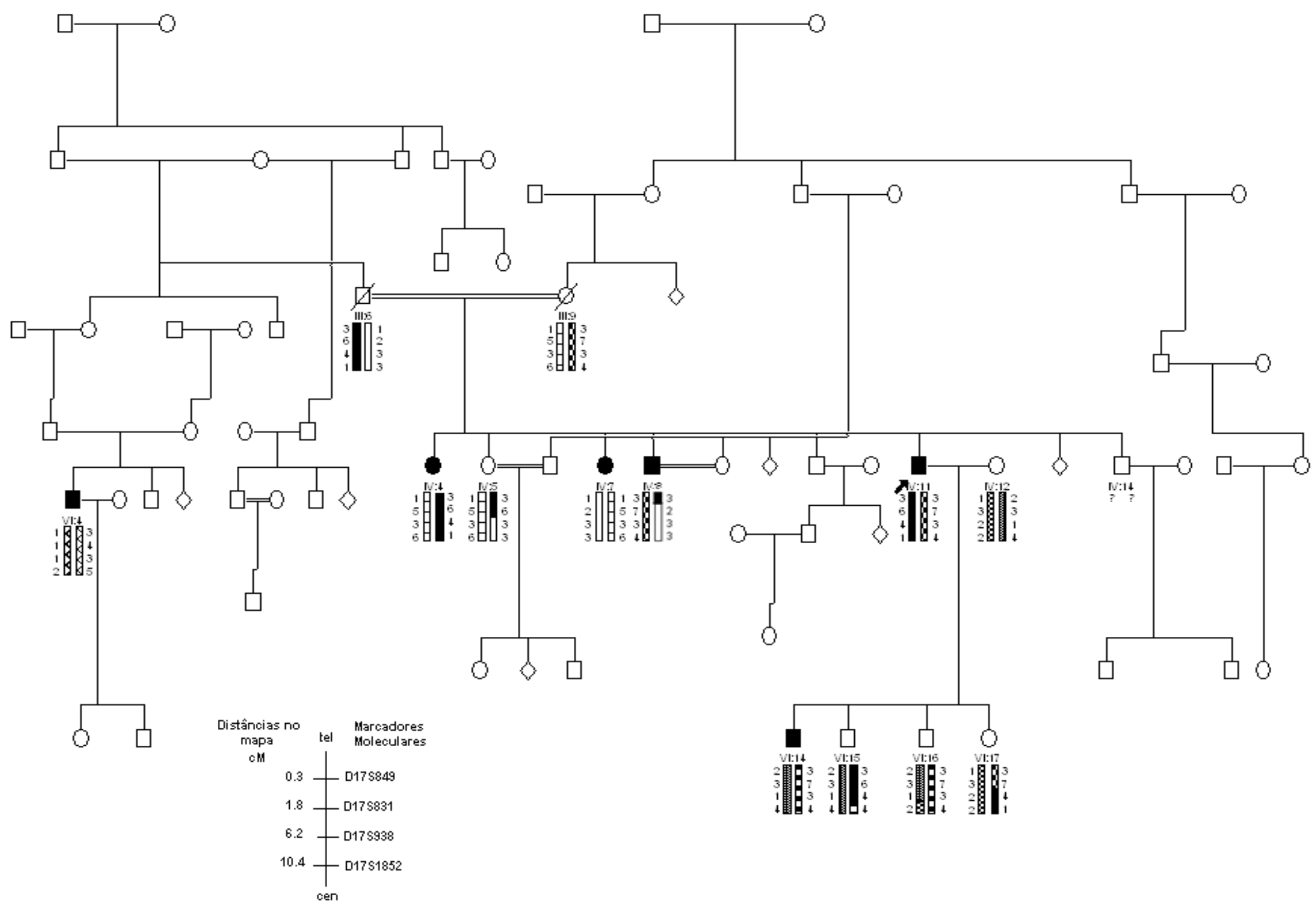

Figura 20. Heredograma da família 2 mostrando os haplótipos da região cromossômica 17p13.3-17p13. Os indivíduos assinalados em preto são afetados um quadro clínico variado de malformações de mãos e pés, incluindo aplasia/hipoplasia fibular. 


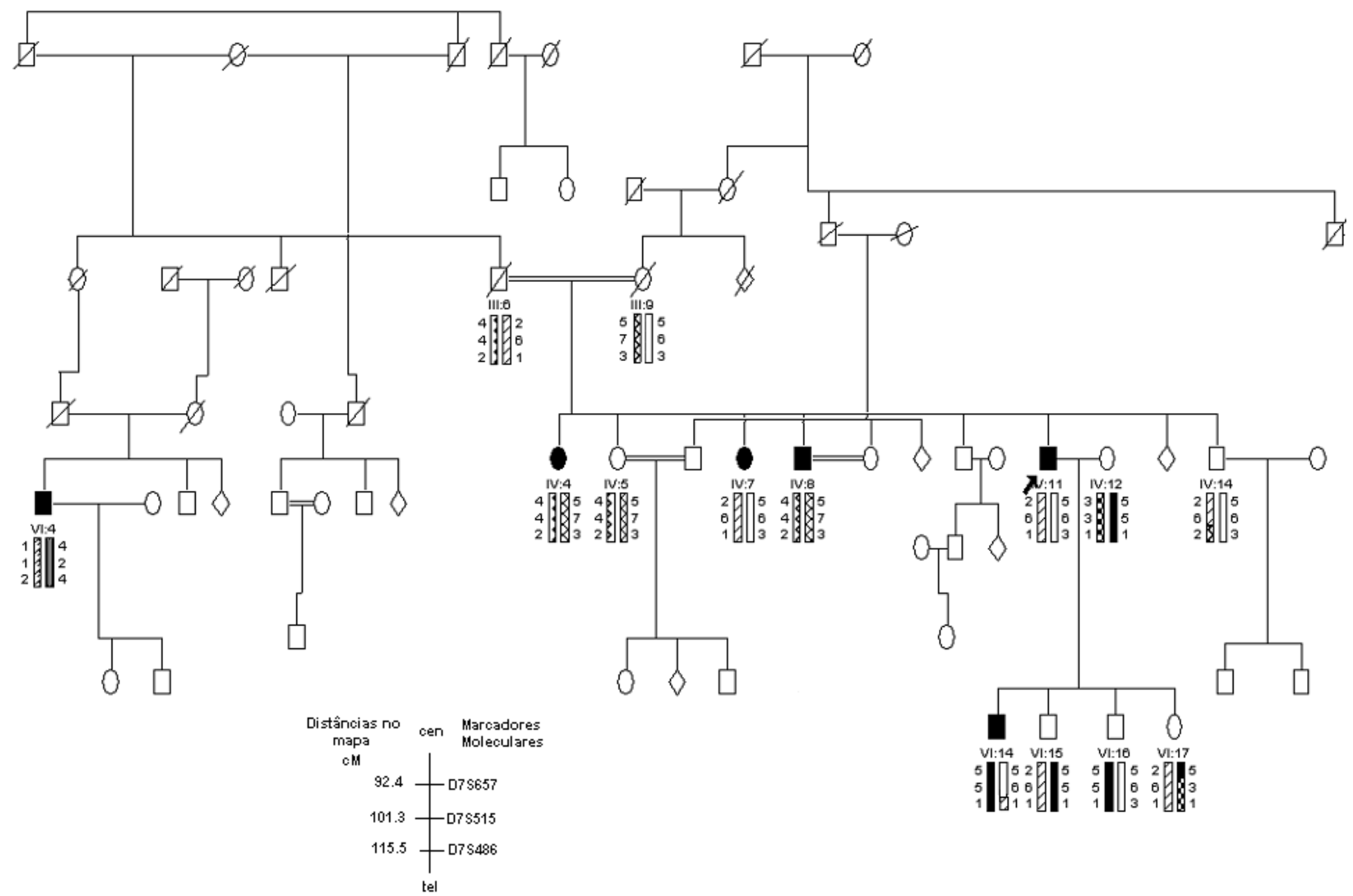

Figura 21. Heredograma da família 2 mostrando os haplótipos da região cromossômica 7q21.Os indivíduos assinalados em preto são afetados por um quadro clínico variado de malformações de mãos e pés, incluindo aplasia/hipoplasia fibular. 


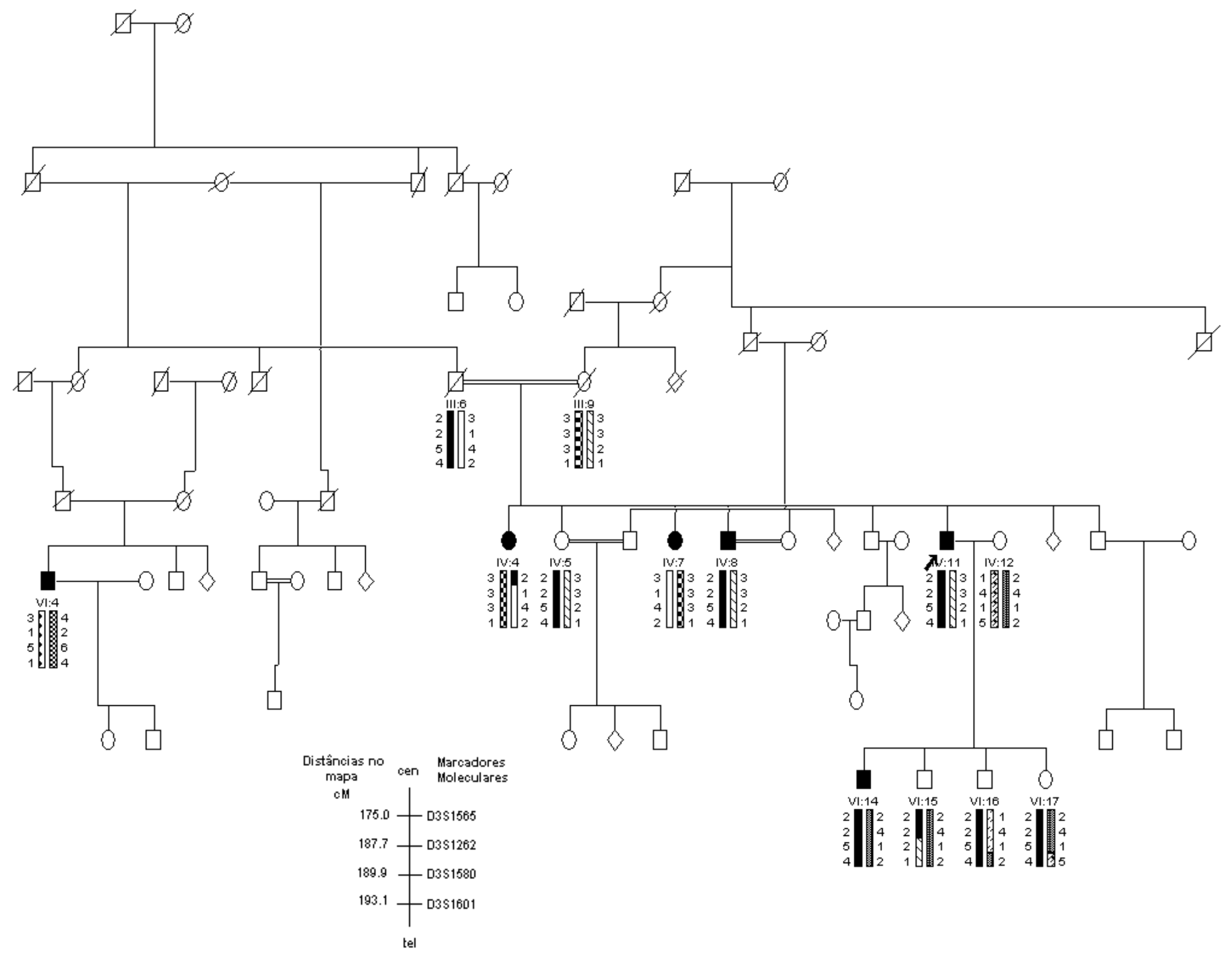

Figura 22. Heredograma da família 2 mostrando os haplótipos da região cromossômica 3q27. Os indivíduos assinalados em preto são afetados por um quadro clínico variado de malformações de mãos e pés, incluindo aplasia/hipoplasia fibular. 


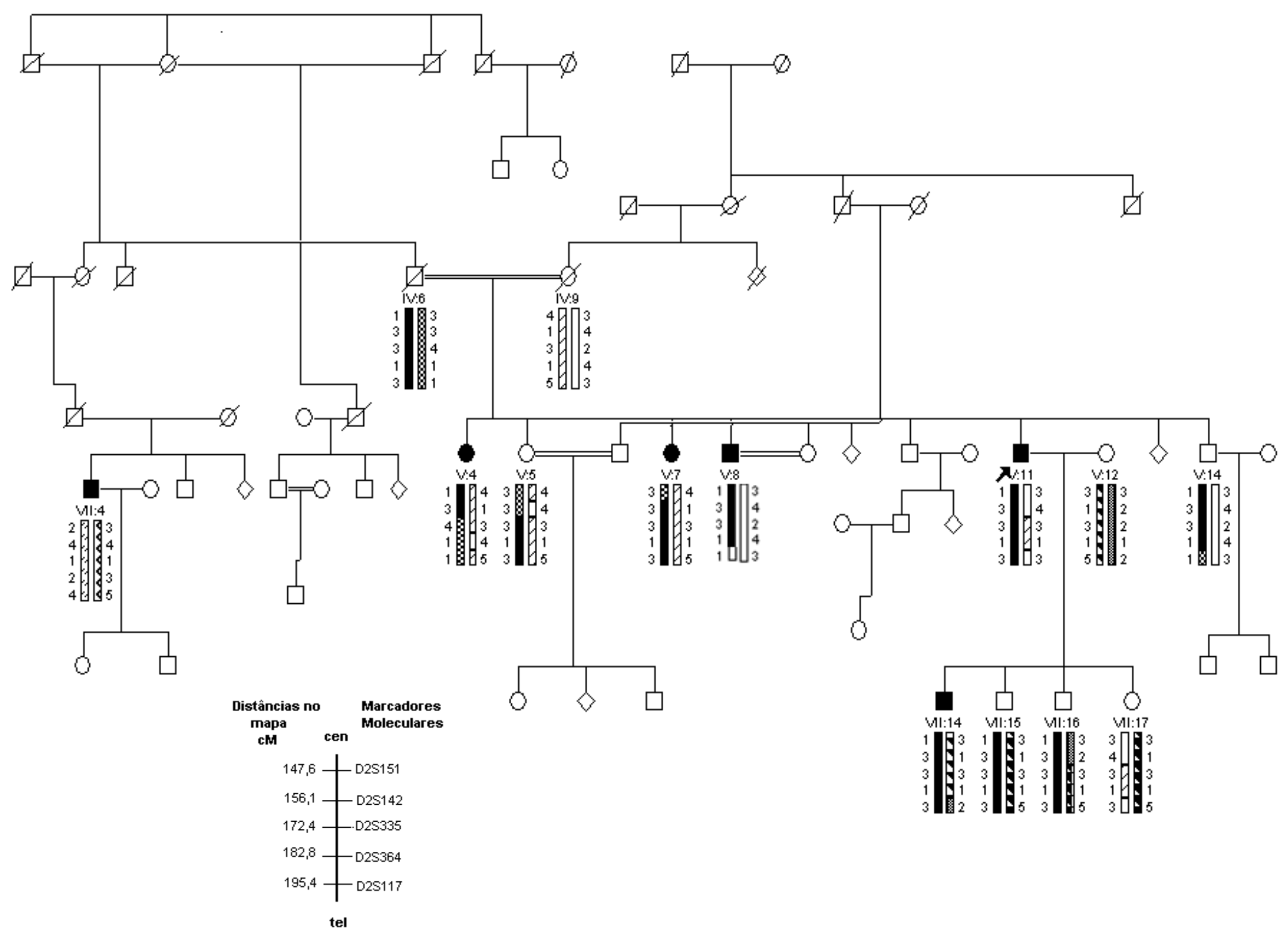

Figura 23.Heredograma da família 2 mostrando os haplótipos da região cromossômica 2q31. Os indivíduos assinalados em preto são afetados por um quadro clínico variado de malformações de mãos e pés, incluindo aplasia/hipoplasia fibular. 
Tabela 8: Lod scores de dois pontos calculados com o programa MLINK do pacote FASTLINK em relação aos microssatélites da região cromossômica 17p13.3-17p13. O dois modelos de herança autossômica foram utilizados para a realização do calculo. (A) Herança autossômica dominante e (B) Herança autossômica recessiva

(A)

\begin{tabular}{|l|l|l|l|l|l|l|l|}
\cline { 2 - 8 } \multicolumn{1}{c|}{} & \multicolumn{7}{c|}{ Frações de recombinação } \\
\hline Microssatélites & $\mathbf{0 , 0 0}$ & $\mathbf{0 , 0 1}$ & $\mathbf{0 , 0 5}$ & $\mathbf{0 , 1}$ & $\mathbf{0 , 2}$ & $\mathbf{0 , 3}$ & $\mathbf{0 , 4}$ \\
\hline D17S849 & -2.79 & -1.26 & -0.61 & -0.35 & -0.14 & -0.04 & -0.006 \\
\hline D17S831 & -5.74 & -4.95 & -2.98 & -1.92 & -0.92 & -0.43 & -0.15 \\
\hline D17S938 & -2.19 & -2.09 & -1.33 & -0.86 & -0.44 & -0.24 & -0.11 \\
\hline D17S1852 & -5.74 & -4.95 & -2.98 & -1.92 & -0.92 & -0.43 & -0.15 \\
\hline
\end{tabular}

(B)

\begin{tabular}{|l|l|l|l|l|l|l|l|}
\cline { 2 - 8 } \multicolumn{1}{c|}{} & \multicolumn{7}{c|}{ Frações de recombinação } \\
\hline Microssatélites & $\mathbf{0 , 0 0}$ & $\mathbf{0 , 0 1}$ & $\mathbf{0 , 0 5}$ & $\mathbf{0 , 1}$ & $\mathbf{0 , 2}$ & $\mathbf{0 , 3}$ & $\mathbf{0 , 4}$ \\
\hline D17S849 & -infini & -6.59 & -3.24 & -1.92 & -0.78 & -0.28 & -0.06 \\
\hline D17S831 & -infini & -6.94 & -3.55 & -2.18 & -0.96 & -0.39 & -0.10 \\
\hline D17S938 & -infini & -2.10 & -0.82 & -0.38 & -0.09 & -0.01 & -0.003 \\
\hline D17S1852 & -infini & -8.05 & -4.01 & -2.41 & -1.02 & -0.40 & -0.10 \\
\hline
\end{tabular}

Tabela 9: Lod scores de dois pontos calculados com o programa MLINK do pacote FASTLINK em relação aos microssatélites da região cromossômica 7q21. O dois modelos de herança autossômica foram utilizados para a realização do calculo. (A) Herança autossômica dominante e (B) Herança autossômica recessiva

(A)

\begin{tabular}{|l|l|l|l|l|l|l|l|}
\cline { 2 - 8 } \multicolumn{1}{c|}{} & \multicolumn{7}{c|}{ Frações de recombinação } \\
\hline Microssatélites & $\mathbf{0 . 0 0}$ & $\mathbf{0 . 0 1}$ & $\mathbf{0 . 0 5}$ & $\mathbf{0 . 1}$ & $\mathbf{0 . 2}$ & $\mathbf{0 . 3}$ & $\mathbf{0 . 4}$ \\
\hline D7S657 & -2.25 & -2.25 & -2.07 & -1.55 & -0.81 & -0.39 & -0.14 \\
\hline D7S515 & -5.58 & -3.85 & -2.10 & -1.30 & -0.58 & -0.24 & -0.07 \\
\hline D7S486 & -2.95 & -2.54 & -1.36 & -0.78 & -0.27 & -0.05 & -0.024 \\
\hline
\end{tabular}


(B)

\begin{tabular}{|l|l|l|l|l|l|l|l|}
\cline { 2 - 8 } \multicolumn{1}{c|}{} & \multicolumn{7}{c|}{ Frações de recombinação } \\
\hline Microssatélites & $\mathbf{0 . 0 0}$ & $\mathbf{0 . 0 1}$ & $\mathbf{0 . 0 5}$ & $\mathbf{0 . 1}$ & $\mathbf{0 . 2}$ & $\mathbf{0 . 3}$ & $\mathbf{0 . 4}$ \\
\hline D7S657 & -infini & -3.89 & -1.89 & -1.10 & -0.43 & -0.15 & -0.03 \\
\hline D7S515 & -infini & -9.79 & -5.04 & -3.11 & -1.38 & -0.55 & -0.14 \\
\hline D7S486 & -infini & -3.12 & -1.65 & -1.01 & -0.43 & -0.16 & -0.03 \\
\hline
\end{tabular}

Tabela 10: Lod scores de dois pontos calculados com o programa MLINK do pacote FASTLINK em relação aos microssatélites da região cromossômica 3q27. O dois modelos de herança autossômica foram utilizados para a realização do cálculo. (A) Herança autossômica dominante e (B) Herança autossômica recessiva

(A)

\begin{tabular}{|l|l|l|l|l|l|l|l|}
\cline { 2 - 8 } \multicolumn{1}{c|}{} & \multicolumn{7}{c|}{ Frações de recombinação } \\
\hline Microssatélites & $\mathbf{0 , 0 0}$ & $\mathbf{0 , 0 1}$ & $\mathbf{0 , 0 5}$ & $\mathbf{0 , 1}$ & $\mathbf{0 , 2}$ & $\mathbf{0 , 3}$ & $\mathbf{0 , 4}$ \\
\hline D3S1565 & -3.04 & -2.39 & -1.17 & -0.65 & -0.22 & -0.04 & 0.01 \\
\hline D3S1262 & -2.78 & -2.36 & -1.23 & -0.71 & -0.26 & -0.06 & 0.01 \\
\hline D3S1580 & -2.56 & -2.28 & -1.21 & -0.68 & -0.21 & -0.02 & 0.03 \\
\hline D3S1601 & -2.71 & -2.37 & -1.25 & -0.71 & -0.23 & -0.03 & 0.03 \\
\hline
\end{tabular}

(B)

\begin{tabular}{|l|l|l|l|l|l|l|l|}
\cline { 2 - 8 } \multicolumn{1}{c|}{} & \multicolumn{7}{c|}{ Frações de recombinação } \\
\hline Microssatélites & $\mathbf{0 , 0 0}$ & $\mathbf{0 , 0 1}$ & $\mathbf{0 , 0 5}$ & $\mathbf{0 , 1}$ & $\mathbf{0 , 2}$ & $\mathbf{0 , 3}$ & $\mathbf{0 , 4}$ \\
\hline D3S1565 & -infini & -4.15 & -2.10 & -1.27 & -0.53 & -0.20 & -0.04 \\
\hline D3S1262 & -infini & -2.83 & -1.46 & -0.91 & -0.40 & -0.16 & -0.04 \\
\hline D3S1580 & -infini & -5.65 & -2.91 & -1.79 & -0.78 & -0.30 & -0.07 \\
\hline D3S1601 & -infini & -5.64 & -2.90 & -1.78 & -0.78 & -0.30 & -0.07 \\
\hline
\end{tabular}


Tabela 11: Lod scores de dois pontos calculados com o programa MLINK do pacote FASTLINK em relação aos microssatélites da região cromossômica $2 q 31$. O dois modelos de herança autossômica foram utilizados para a realização do cálculo. (A) Herança autossômica dominante e (B) Herança autossômica recessiva

(A)

\begin{tabular}{|l|l|l|l|l|l|l|l|}
\cline { 2 - 8 } \multicolumn{1}{c|}{} & \multicolumn{7}{c|}{ Frações de recombinação } \\
\hline Microssatélites & $\mathbf{0 , 0 0}$ & $\mathbf{0 , 0 1}$ & $\mathbf{0 , 0 5}$ & $\mathbf{0 , 1}$ & $\mathbf{0 , 2}$ & $\mathbf{0 , 3}$ & $\mathbf{0 , 4}$ \\
\hline D2S151 & -2.86 & -2.10 & -0.88 & -0.40 & -0.04 & 0.05 & 0.05 \\
\hline D2S142 & -2.59 & -1.13 & -0.48 & -0.23 & -0.04 & 0.01 & 0.02 \\
\hline D2S335 & -5.82 & -2.50 & -1.21 & -0.70 & -0.29 & -0.12 & -0.04 \\
\hline D2S364 & -2.78 & -1.32 & -0.67 & -0.41 & -0.18 & -0.08 & -0.03 \\
\hline D2S117 & -5.96 & -3.92 & -2.09 & -1.29 & -0.57 & -0.24 & -0.06 \\
\hline
\end{tabular}

(B)

\begin{tabular}{|l|l|l|l|l|l|l|l|}
\cline { 2 - 8 } \multicolumn{1}{c|}{} & \multicolumn{7}{c|}{ Frações de recombinação } \\
\hline Microssatélites & $\mathbf{0 , 0 0}$ & $\mathbf{0 , 0 1}$ & $\mathbf{0 , 0 5}$ & $\mathbf{0 , 1}$ & $\mathbf{0 , 2}$ & $\mathbf{0 , 3}$ & $\mathbf{0 , 4}$ \\
\hline D2S151 & -infini & -3.86 & -1.83 & -1.04 & -0.38 & -0.12 & -0.02 \\
\hline D2S142 & -infini & -5.56 & -2.84 & -1.73 & -0.74 & -0.28 & -0.06 \\
\hline D2S335 & -infini & -4.85 & -2.21 & -1.20 & -0.40 & -0.11 & -0.01 \\
\hline D2S364 & -infini & -2.75 & -1.40 & -0.85 & -0.35 & -0.13 & -0.02 \\
\hline D2S117 & -infini & -4.67 & -2.02 & -1.01 & -0.23 & 0.01 & 0.03 \\
\hline
\end{tabular}

Parametric Analysis for Recessive_Model

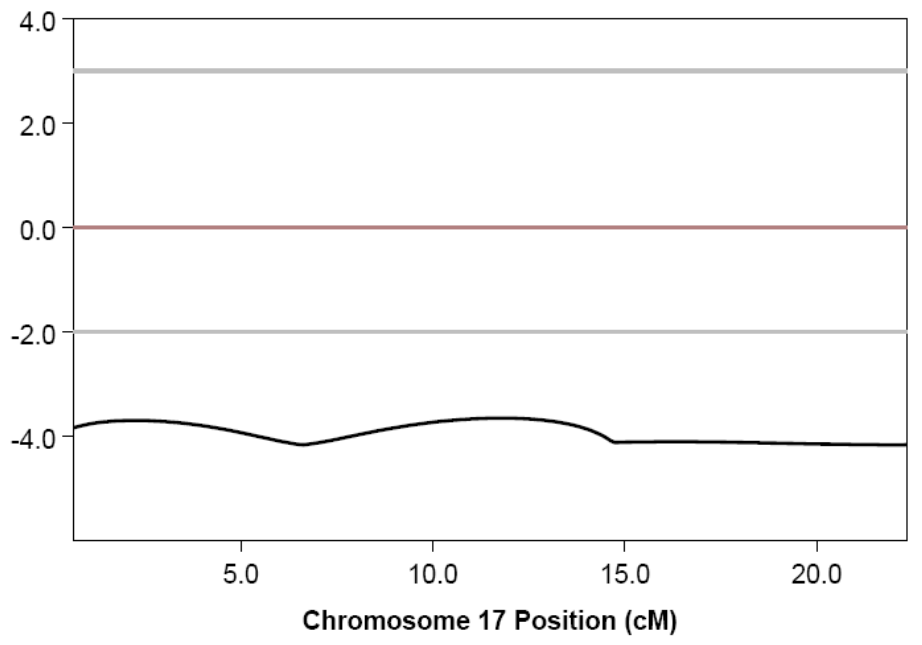

Parametric Analysis for Dominant_Model

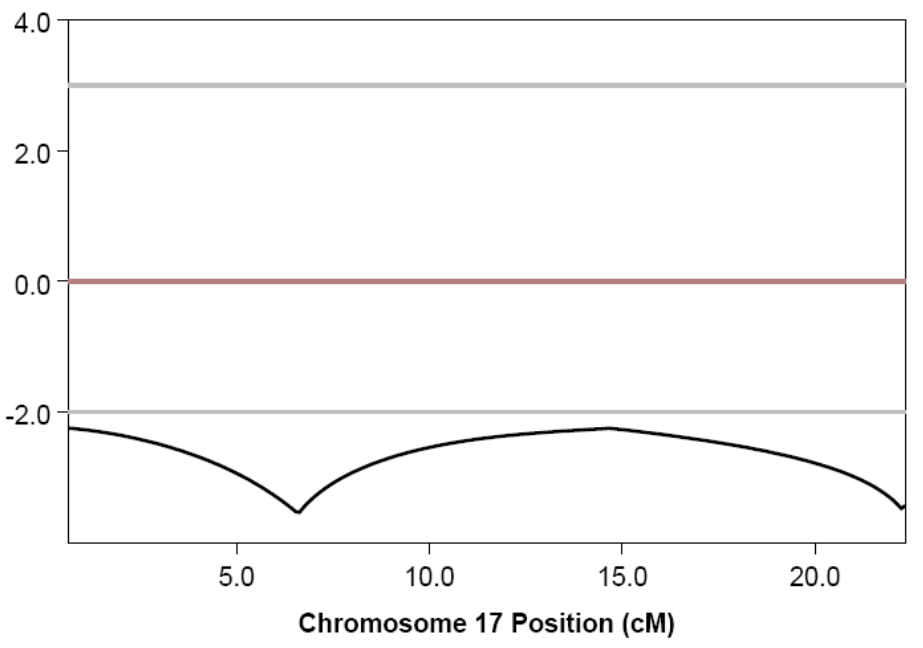

Figura 24. Resultados de lod scores de múltiplos pontos obtidos com os marcadores da região 
Parametric Analysis for Recessive_Model

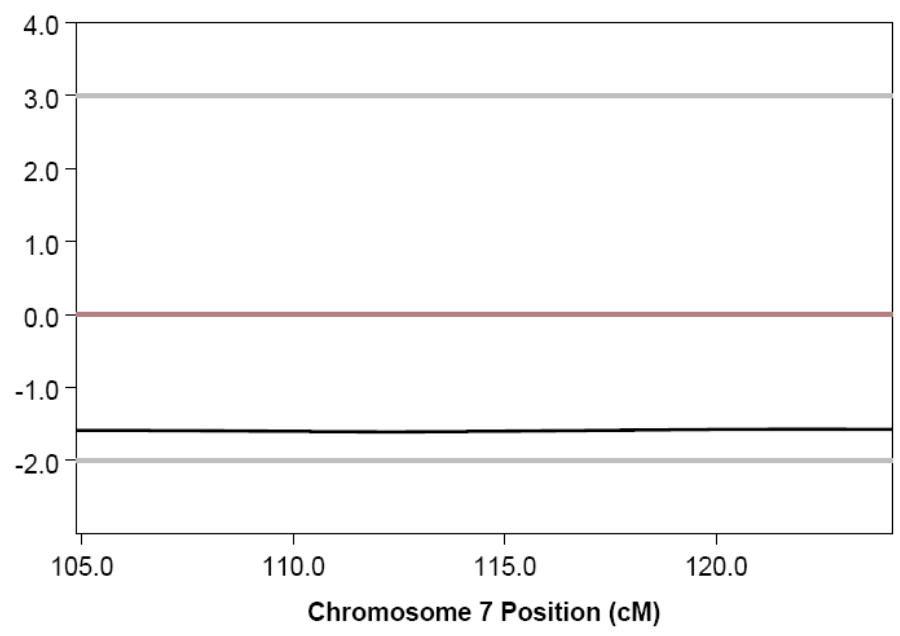

Parametric Analysis for Dominant_Model

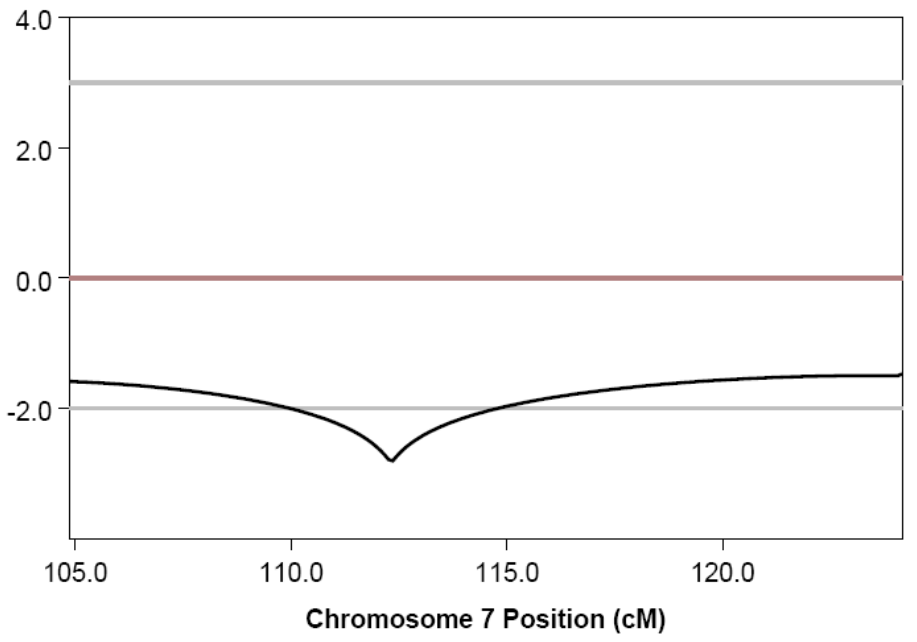

Figura 25. Resultados de lod scores de múltiplos pontos obtidos com os marcadores da região $7 \mathrm{q} 21$, utilizando os dois modelos de herança autossômica.

Parametric Analysis for Recessive_Model

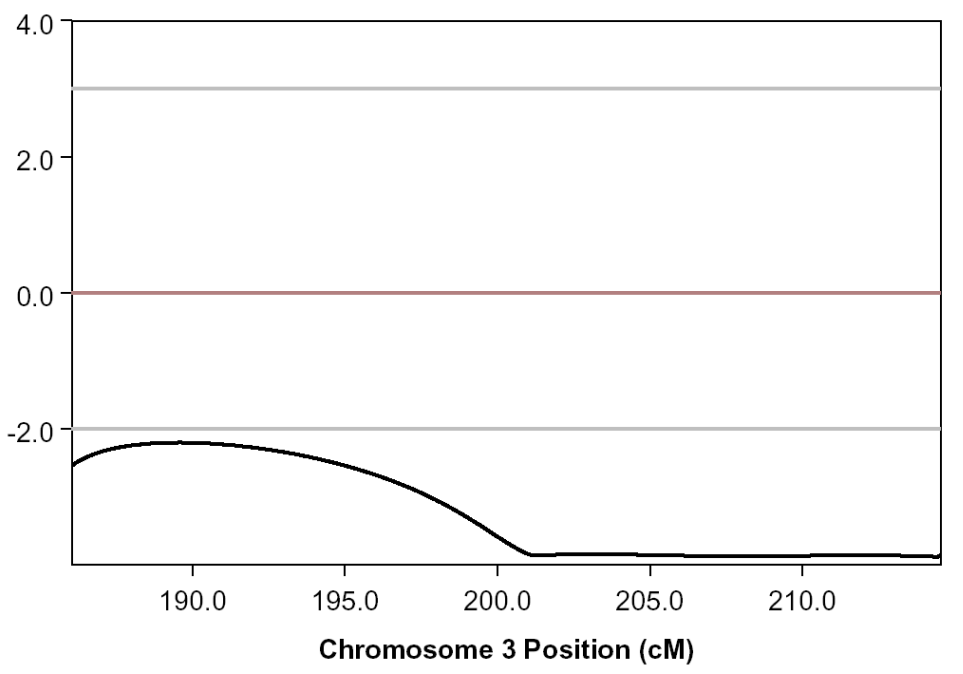

Parametric Analysis for Dominant_Model

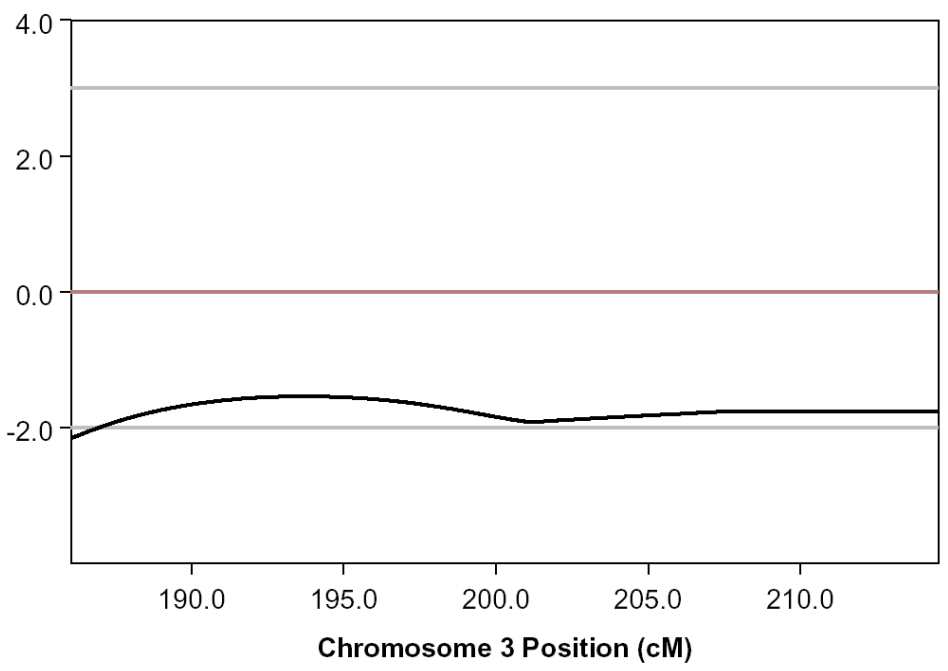

Figura 26. Resultados de lod scores de múltiplos pontos obtidos com os marcadores da região $3 q 27$, utilizando os dois modelos de herança autossômica. 

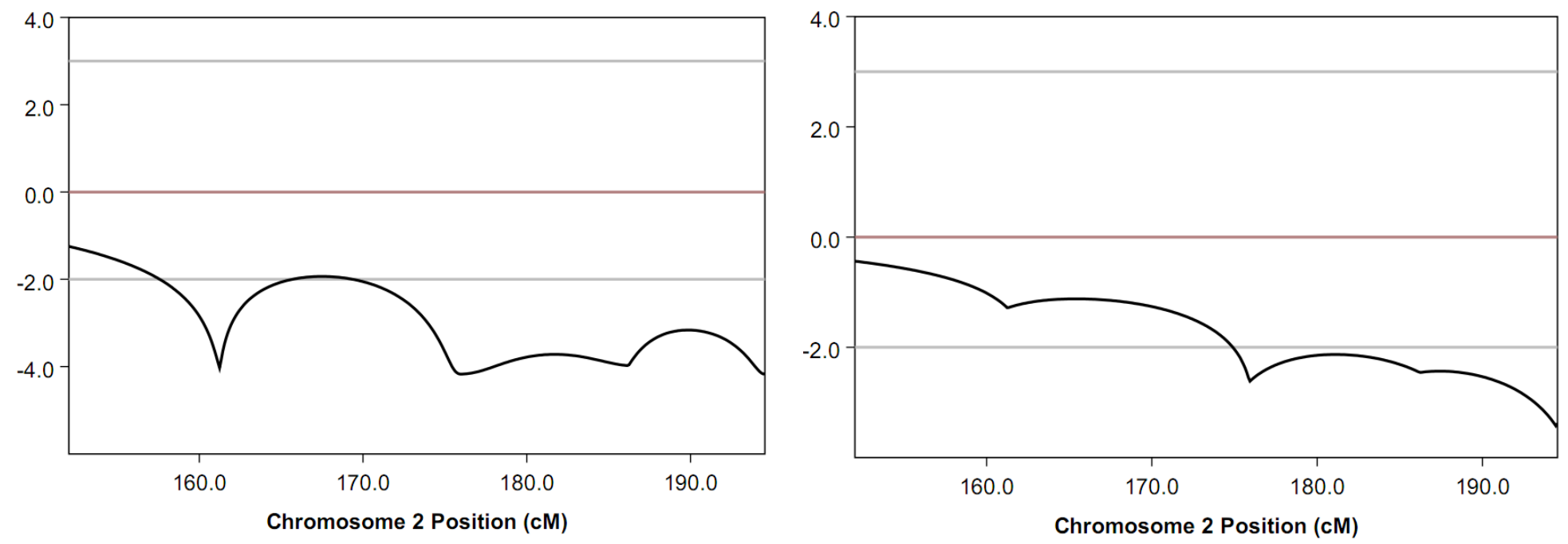

Figura 27. Resultados de lod scores de múltiplos pontos obtidos com os marcadores da região 2q31, utilizando os dois modelos de herança autossômica.

Os microssatélites analisados próximo à região $17 \mathrm{p} 13.3-17 \mathrm{p} 13$, descrita como região candidata a gene de defeitos de membros pelo nosso grupo, não mostraram evidências de ligação. Os lod scores de múltiplos pontos calculados tanto no modelo de herança autossômica dominante como no modelo de herança autossômica recessiva não revelaram valores significativos. Além disso, todos os valores se mostraram menores do que -2.0, o que nos permite concluir que a região 17p13.3-17p13 está excluída como candidata a conter o gene responsável pela doença na família. As análises dos microssatélites próximo ao locos SHFM1 (região cromossômica 7q21), próximo ao locos SHFM4 (região cromossômica 3q27) e próximo ao locos SHFM5 (região cromossômica 2q31) também não mostraram evidência de ligação, considerando-se a segregação dos haplótipos e os valores negativos dos lod scores obtidos nas análises paramétricas. Tanto no modelo de herança autossômica dominante (com penetrância de 0.32) como no modelo de herança autossômica recessiva, os valores encontrados são muito baixos e não indicam lod scores significativos estatisticamente. Desse modo a região $7 q 21$, a região $3 q 27$ e a região $2 q 31$ são improváveis como candidatas a conter o gene responsável pela doença em questão. O lod score 
máximo possível de dois pontos dessa família foi calculado por meio de uma simulação para o padrão de herança autossômico dominante. O valor obtido foi de $\mathbf{1 . 6 1}$, enquanto que o lod máximo calculado por meio da simulação para o padrão de herança autossômico recessivo chegou a 3.51. Esses valores de lod scores máximos obtidos, muito distantes dos valores obtidos com os marcadores já utilizados, corroboram nossa hipótese de que é muito improvável que qualquer um dos cinco locos estudados seja a região candidata a conter o gene responsável pela doença em questão. Esses achados reforçam a idéia de que se trata, realmente, de uma nova síndrome causada por uma mutação em um gene ainda não mapeado. Com base nessas conclusões, executou-se a varredura genômica na tentativa de busca da região cromossômica candidata a explicar a síndrome na família, utilizando as lâminas de 50K do Kit da Affymetrix “GeneChip® Human Mapping 100K Array”. Para a varredura foram selecionados apenas os seis indivíduos afetados. Após exame preliminar dos resultados obtidos com as lâminas de array, descartou-se a presença de possíveis variações de número de cópias nesses indivíduos. As variações dos números de cópias também foram excluídas por meio do uso de lâminas de array CGH (array CGH 108 K- Illumina/Agilent). Essa análise foi realizada pela pós-doutoranda Erika Freitas, do laboratório da Dra. Carla Rosenberg. Realizou-se o cálculo de lod score de múltiplos pontos para todos os SNPs estudados na família com o auxilio do programa Merlin (Figura 28).

Parametric Analysis for Dominant_Model

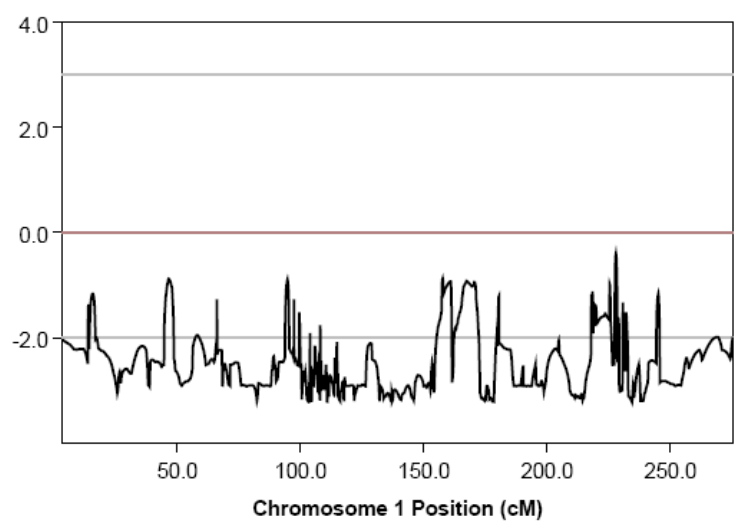

Parametric Analysis for Recessive_Model

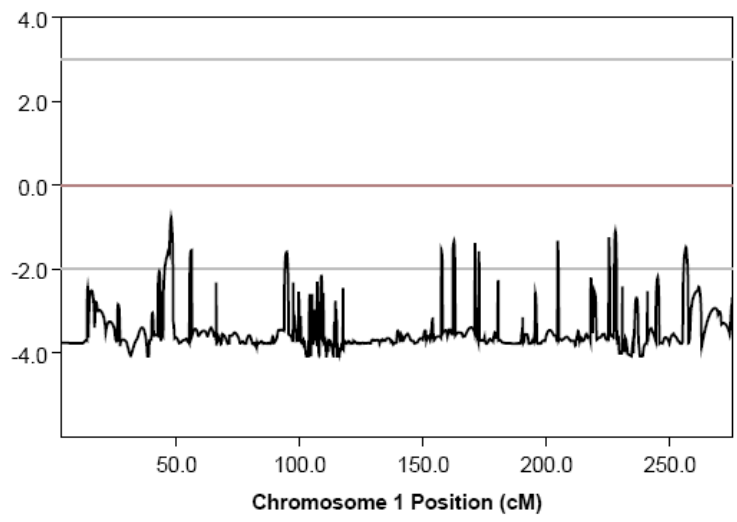

Figura 28: Resultados dos lods scores de múltiplos pontos dos marcadores de cada autossomo calculados pelo programa Merlin. As linhas horizontais de coloração cinza claro em cada gráfico indicam os valores que se convencionaram para excluir ligação $(-2,00)$ e aceitar ligação $(+3,00)$. 
Parametric Analysis for Dominant_Model

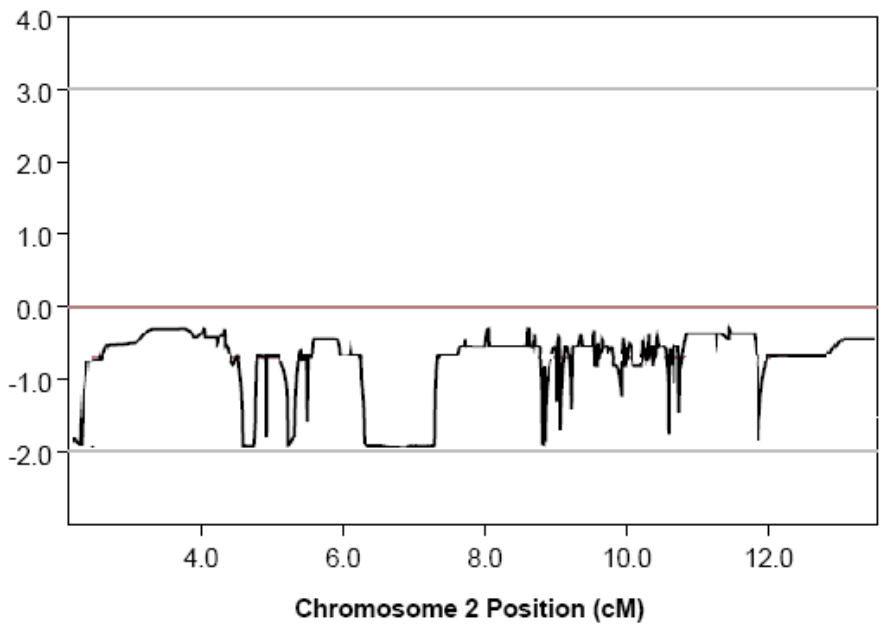

Parametric Analysis for Dominant_Model

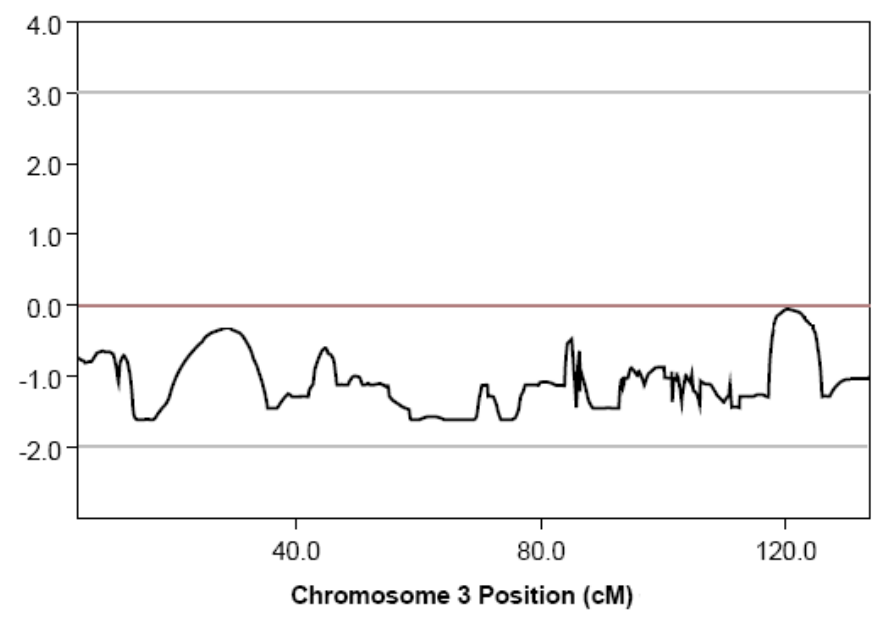

Parametric Analysis for Dominant_Model

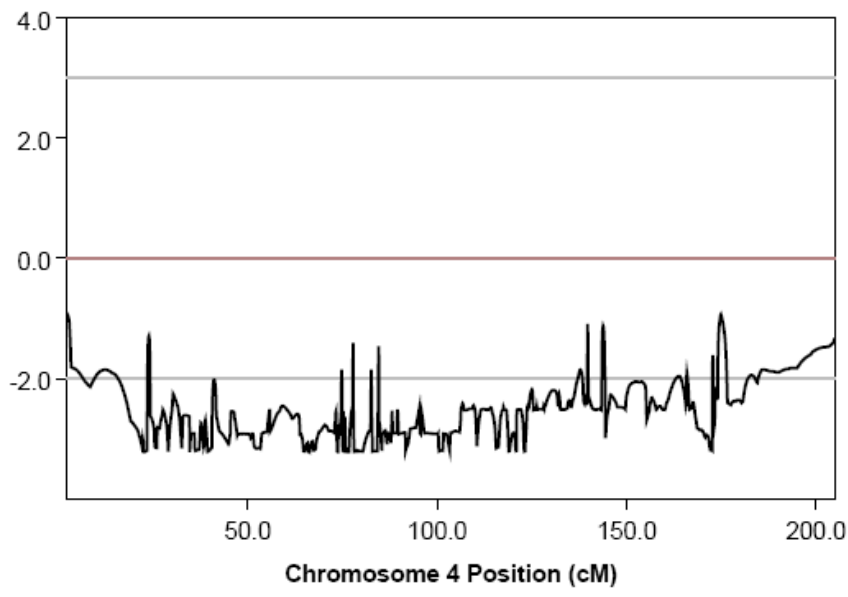

Parametric Analysis for Recessive_Model

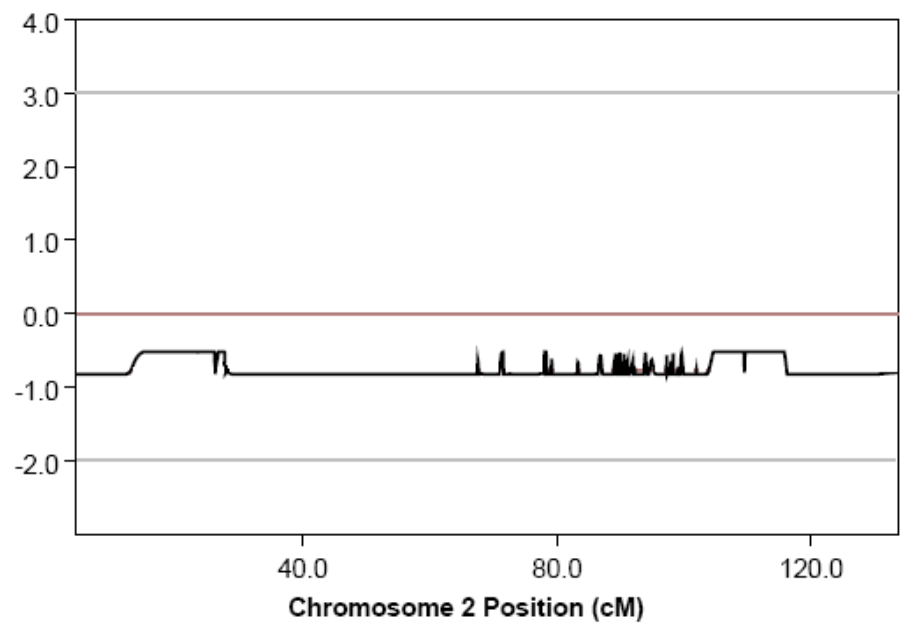

Parametric Analysis for Recessive_Model

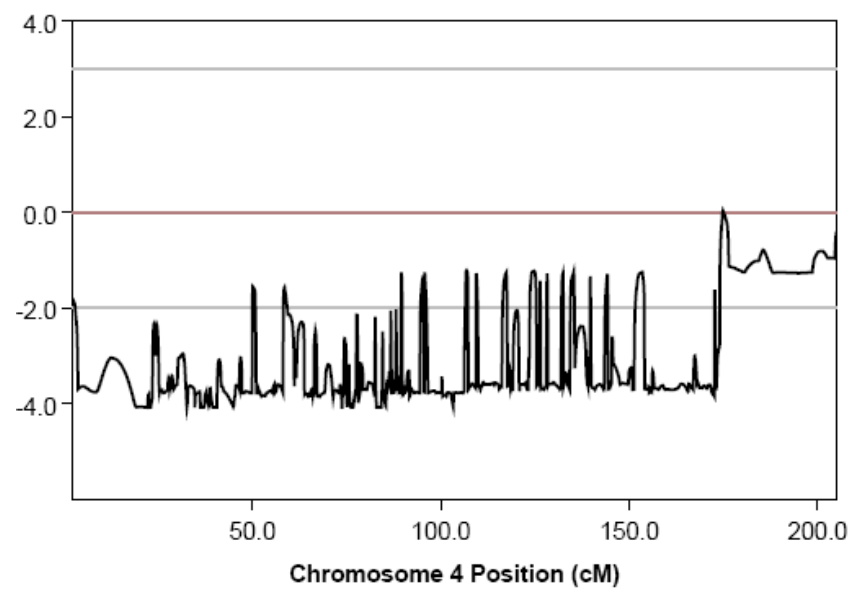

Figura 28 (continuação). Resultados dos lods scores de múltiplos pontos. 
Parametric Analysis for Dominant_Model

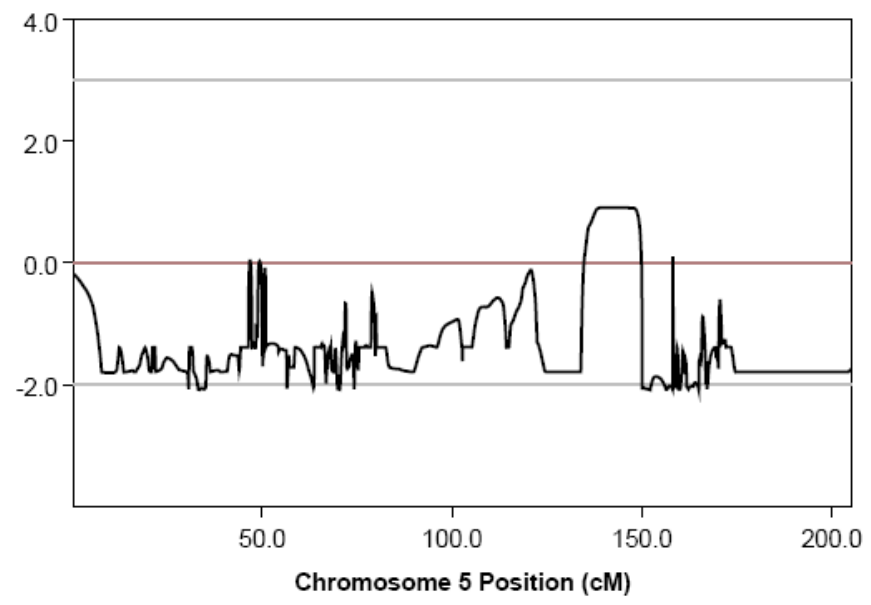

Parametric Analysis for Dominant_Model

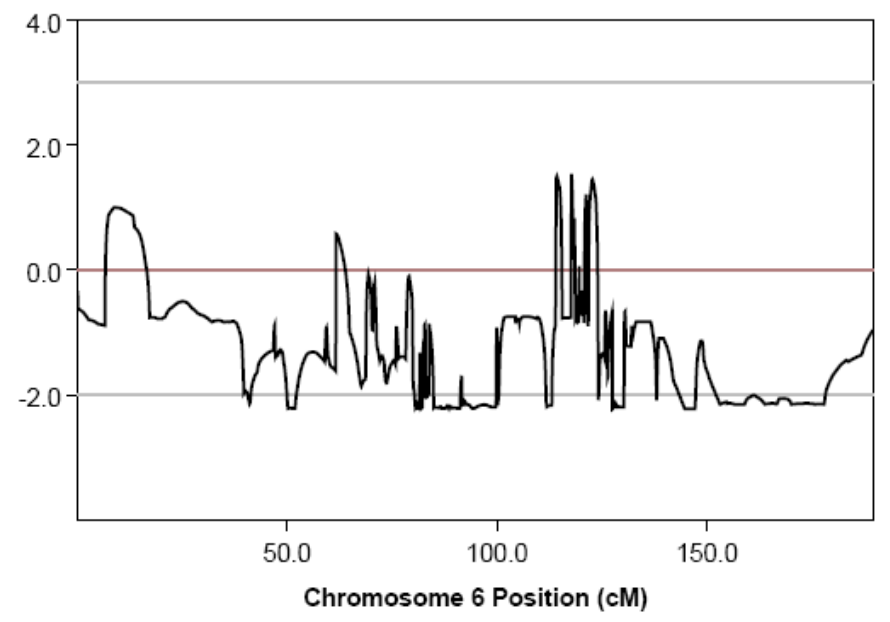

Parametric Analysis for Dominant_Model

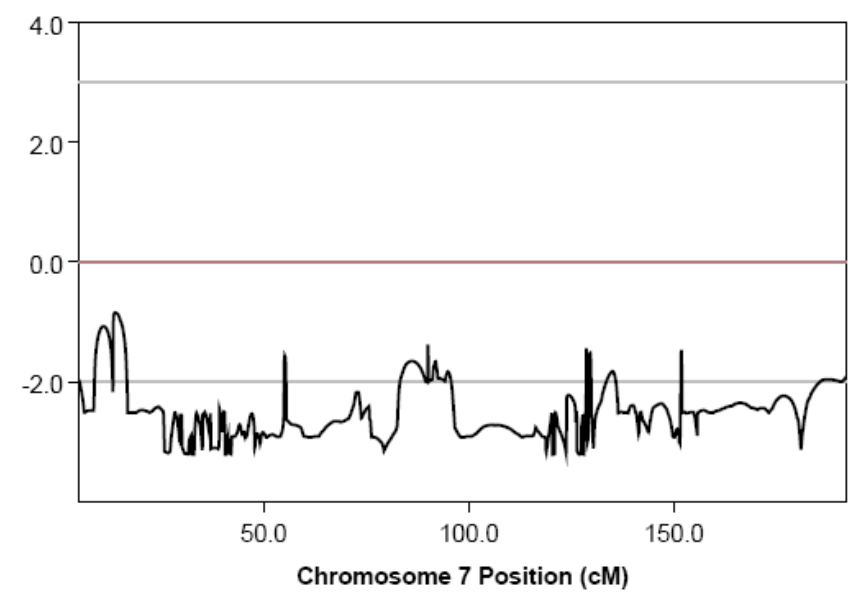

Parametric Analysis for Recessive_Model

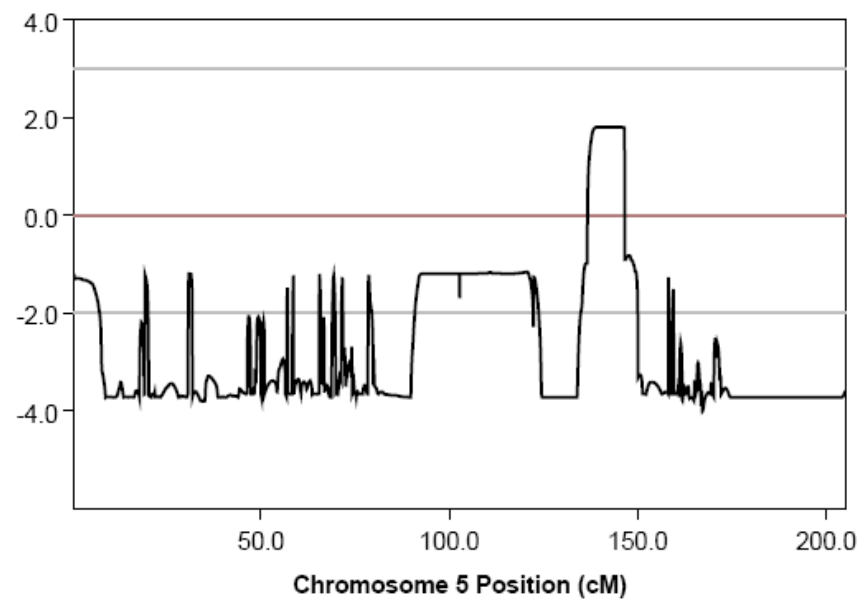

Parametric Analysis for Recessive_Model

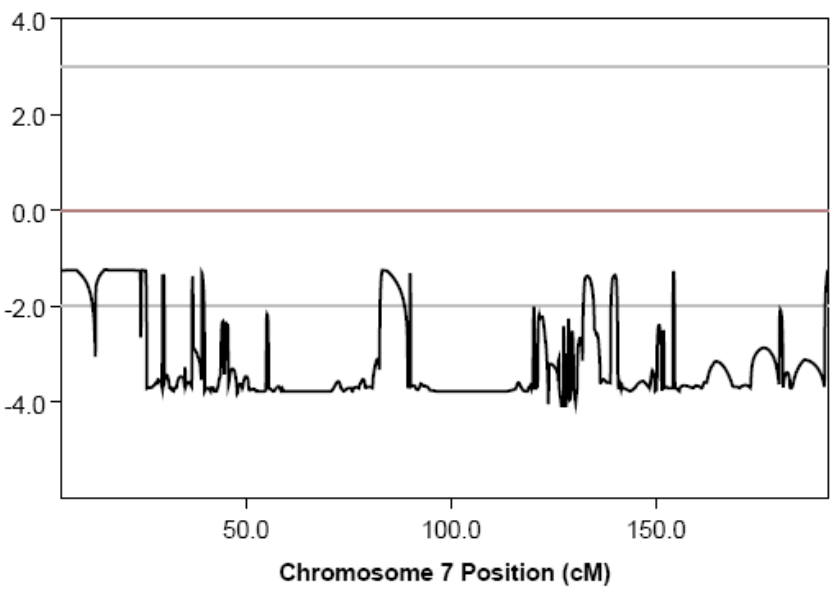

Figura 28 (continuação). Resultados dos lods scores de múltiplos pontos. 
Parametric Analysis for Dominant_Model

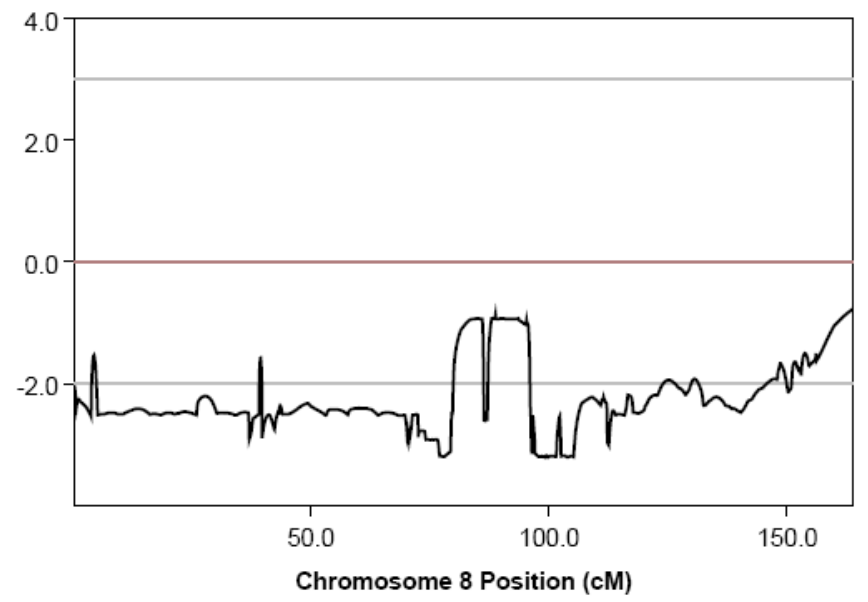

Parametric Analysis for Dominant_Model

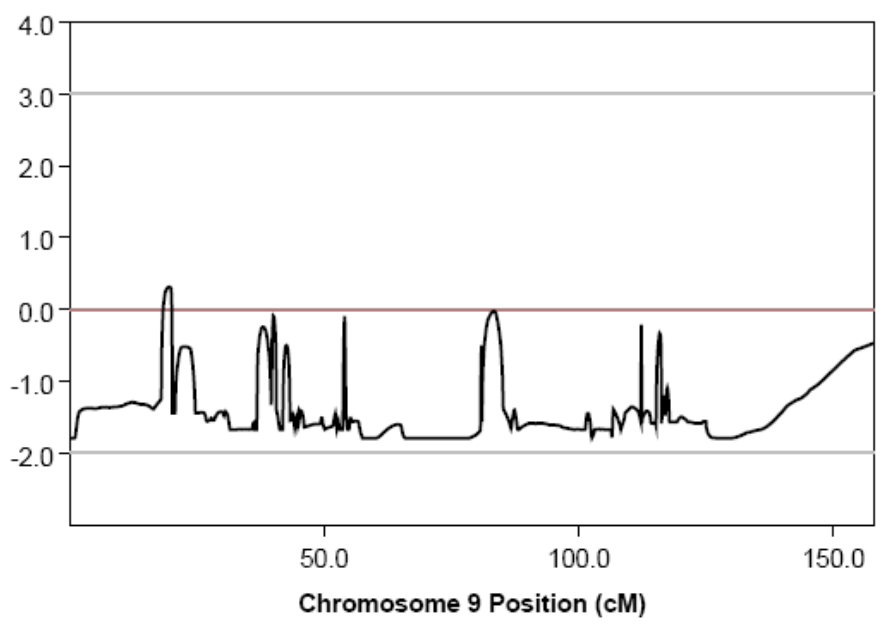

Parametric Analysis for Dominant_Model

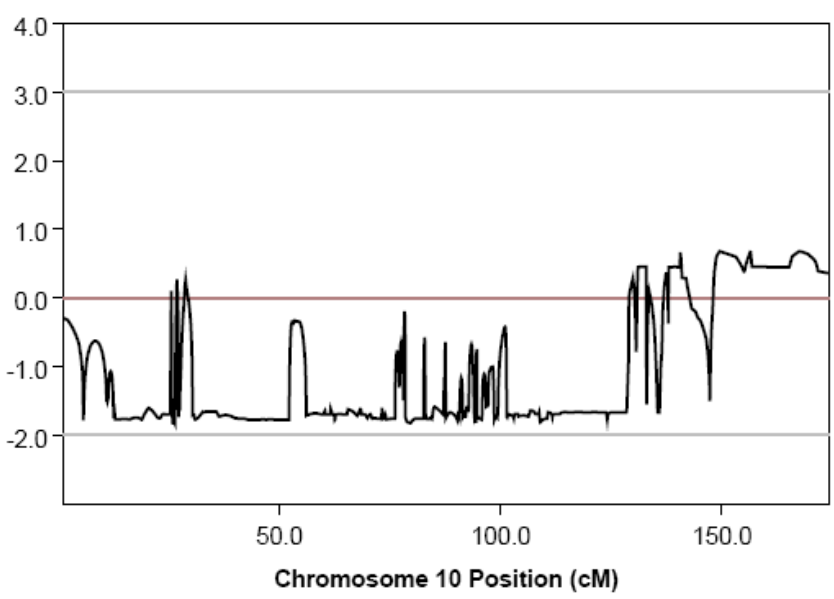

Parametric Analysis for Recessive_Model

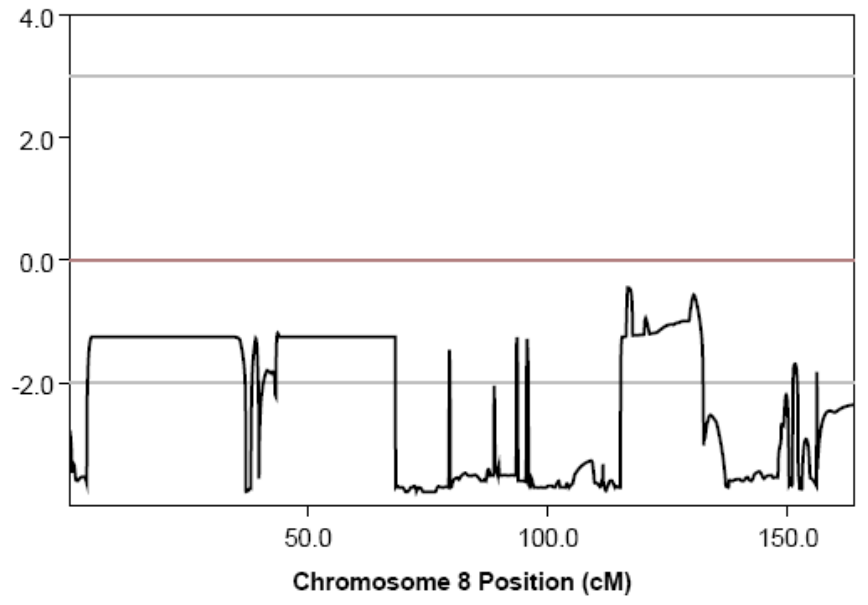

Parametric Analysis for Recessive_Model

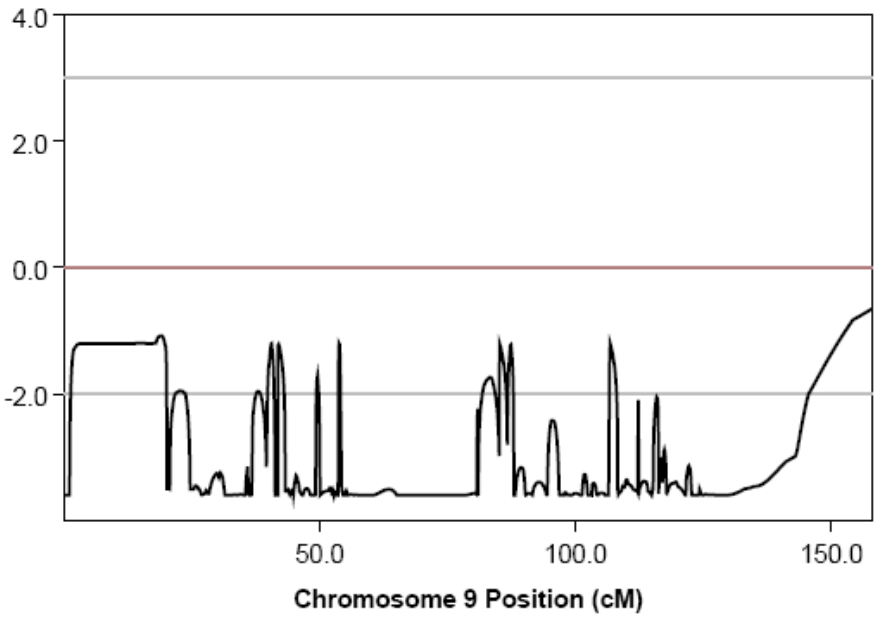

Parametric Analysis for Recessive_Model

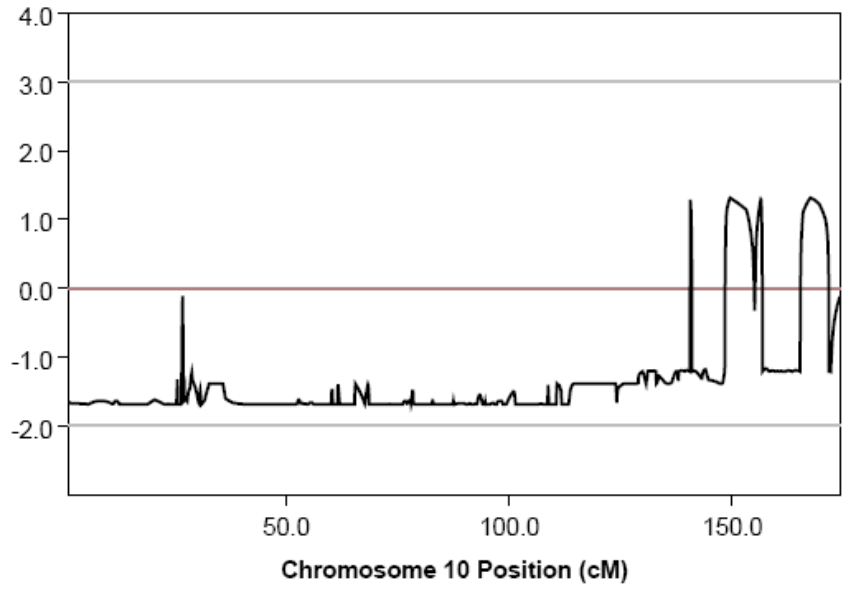

Figura 28 (continuação). Resultados dos lods scores de múltiplos pontos. 
Parametric Analysis for Dominant_Model

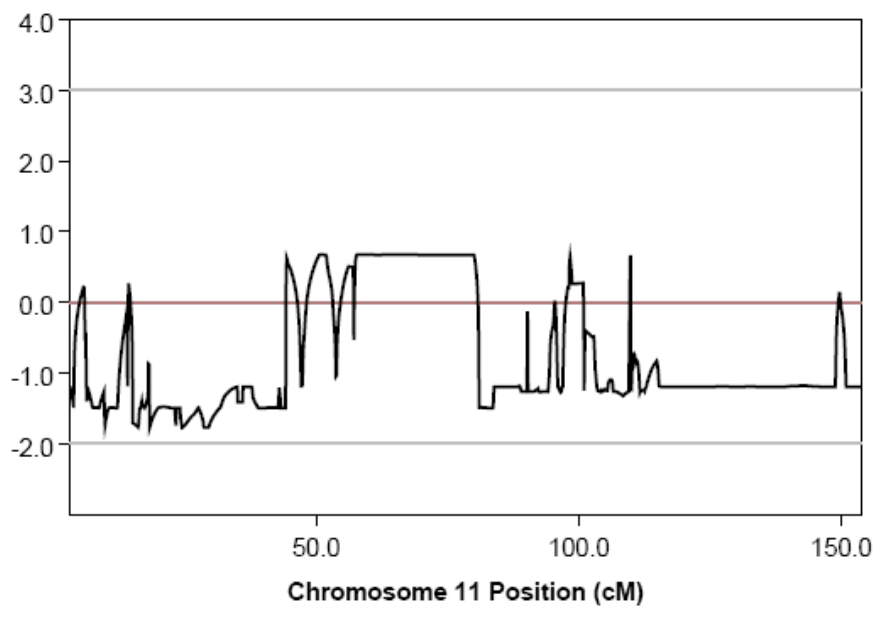

Parametric Analysis for Dominant_Model

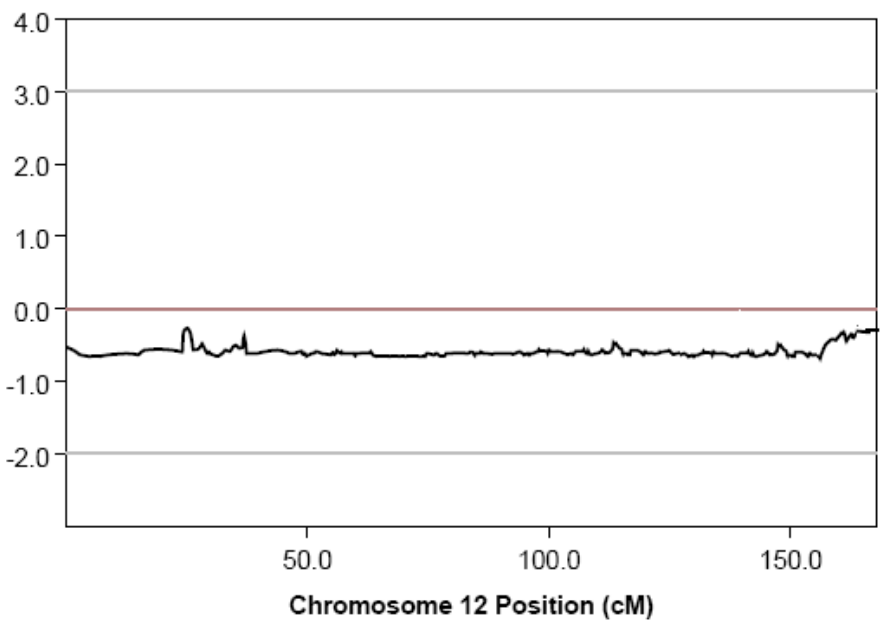

Parametric Analysis for Dominant_Model

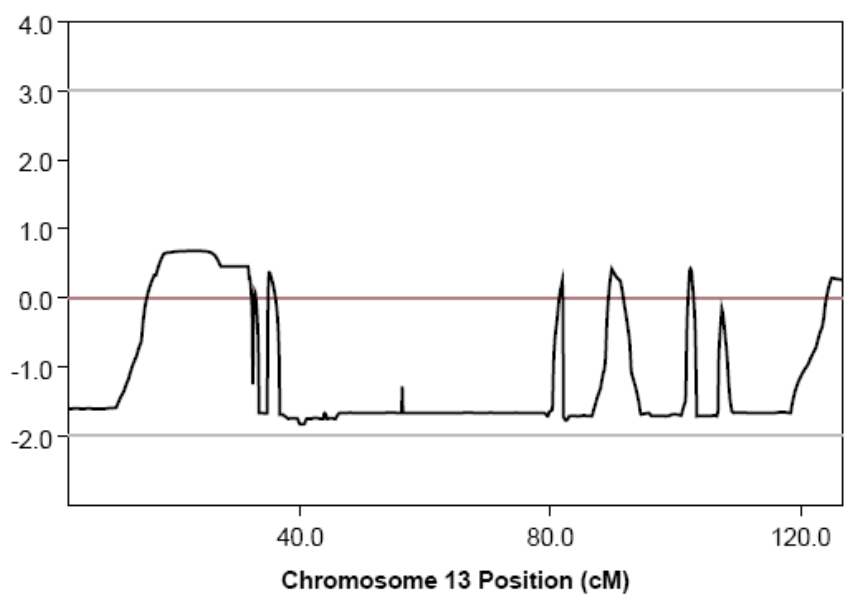

Parametric Analysis for Recessive_Model

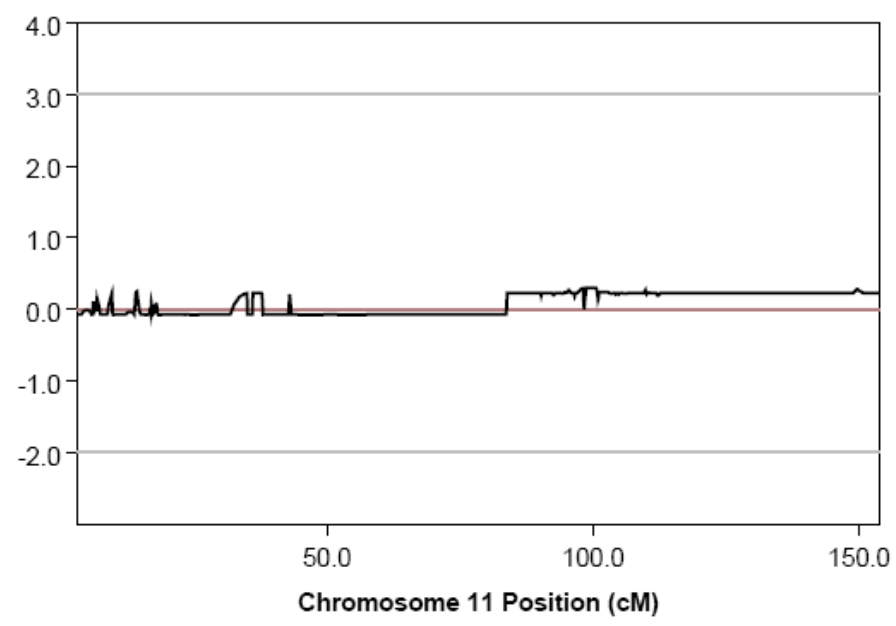

Parametric Analysis for Recessive_Model

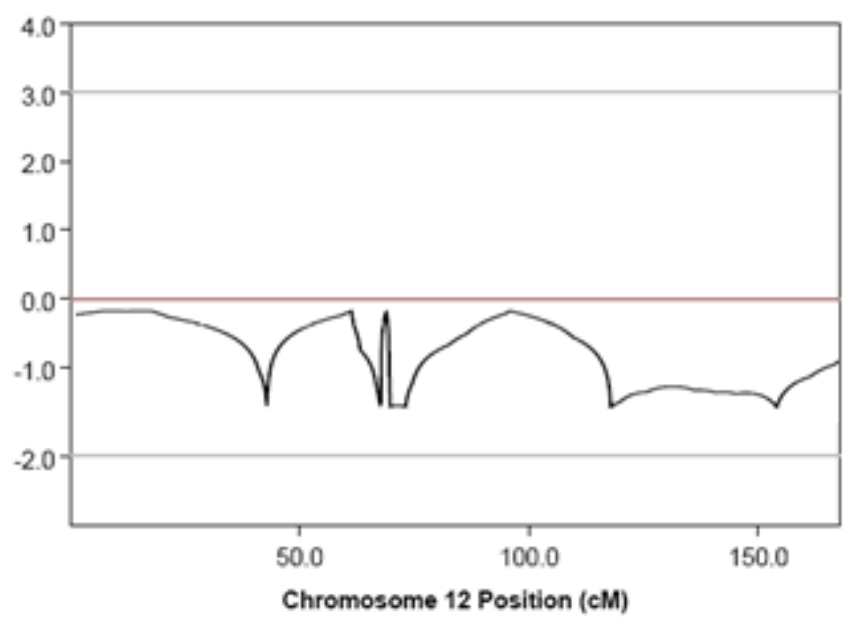

Parametric Analysis for Recessive_Model

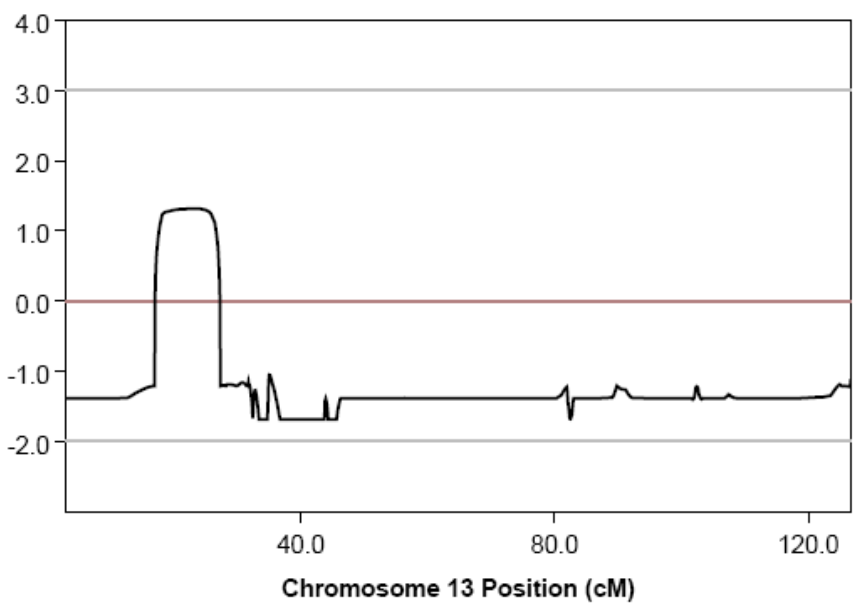

Figura 28 (continuação). Resultados dos lods scores de múltiplos pontos. 
Parametric Analysis for Dominant_Model

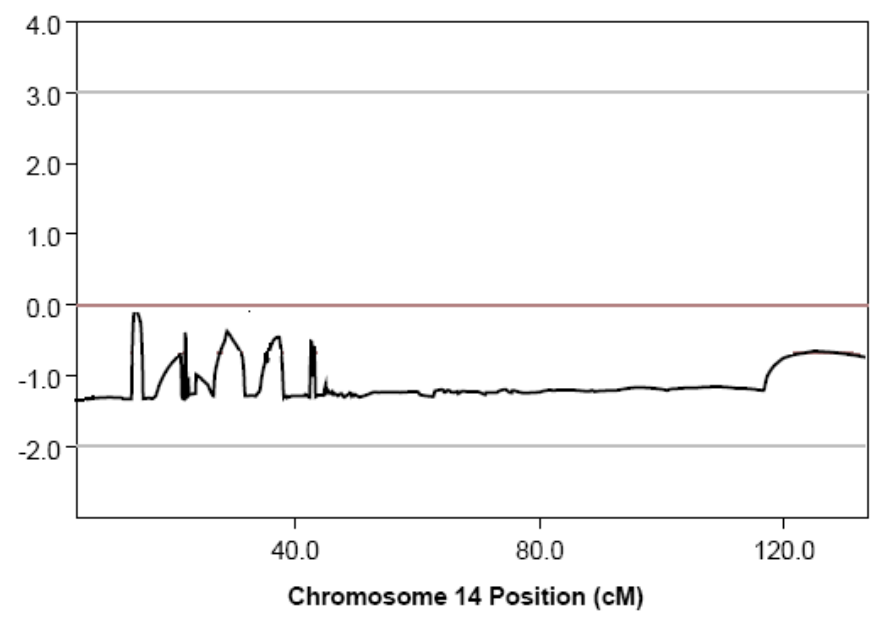

Parametric Analysis for Dominant_Model

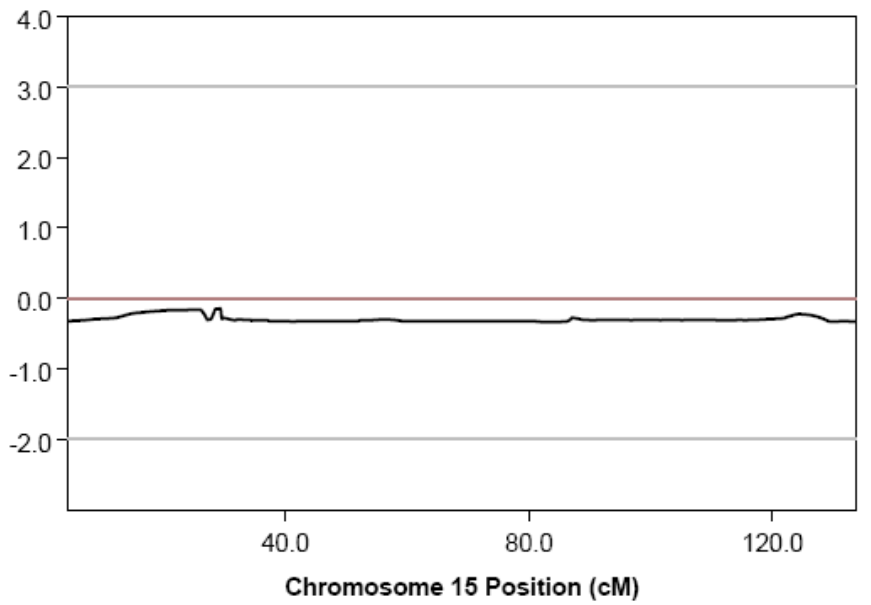

Parametric Analysis for Dominant_Model

Parametric Analysis for Recessive_Model
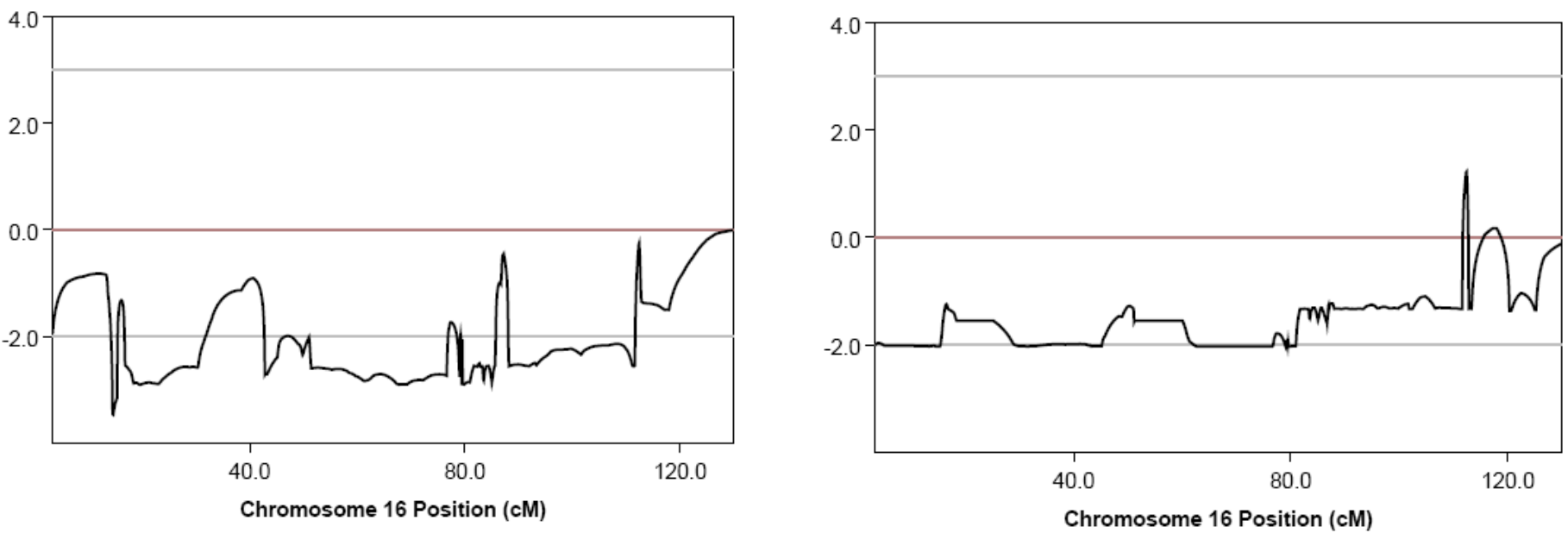

Figura 28 (continuação). Resultados dos lods scores de múltiplos pontos. 
Parametric Analysis for Dominant_Model

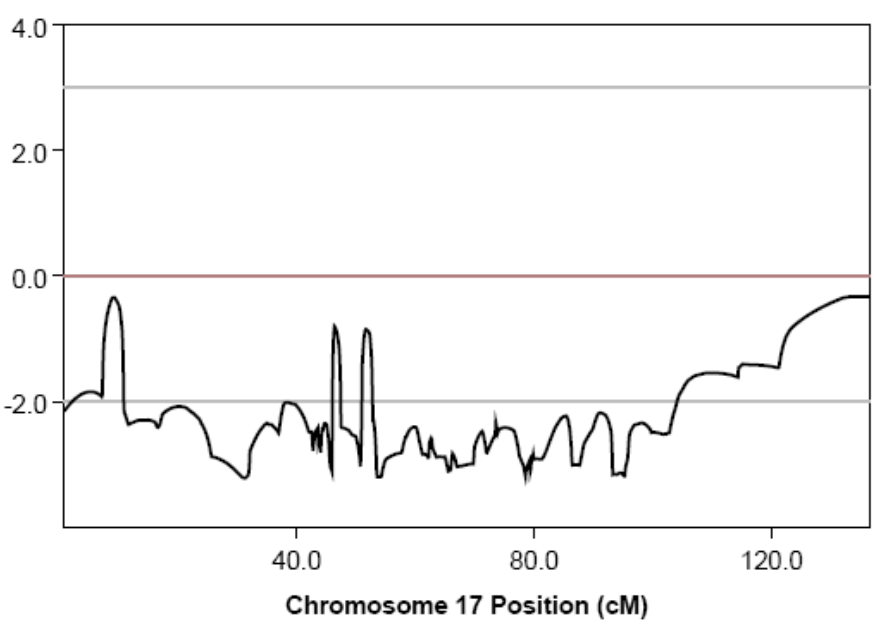

Parametric Analysis for Dominant_Model

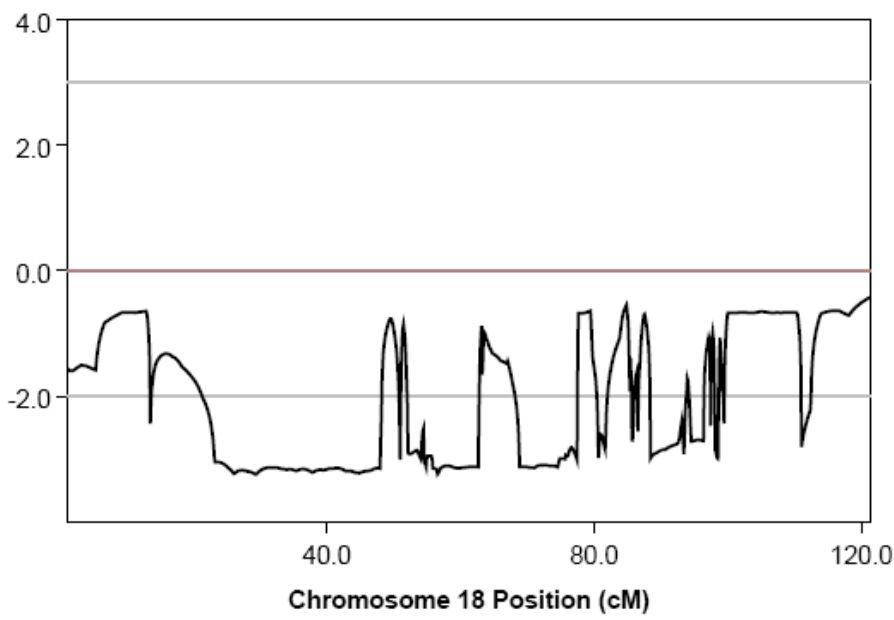

Parametric Analysis for Dominant_Model

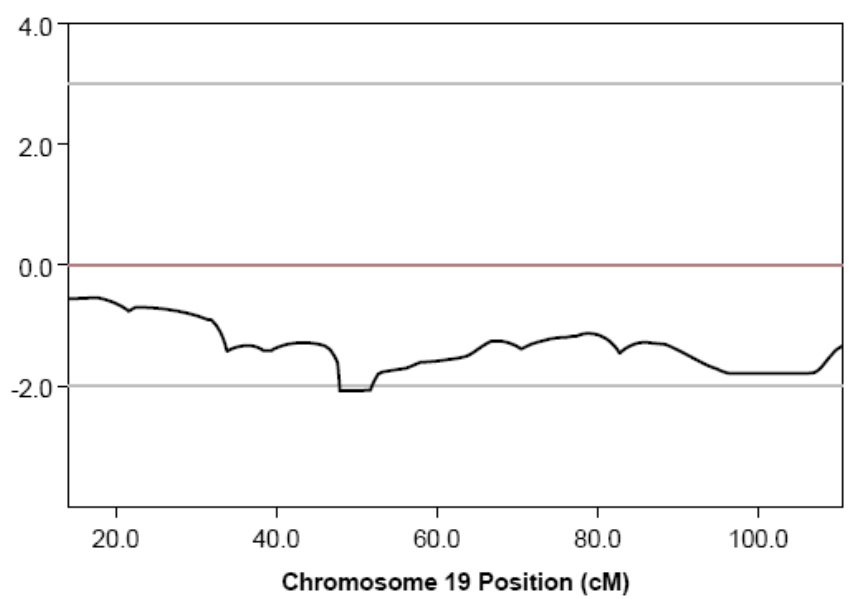

Parametric Analysis for Recessive_Model

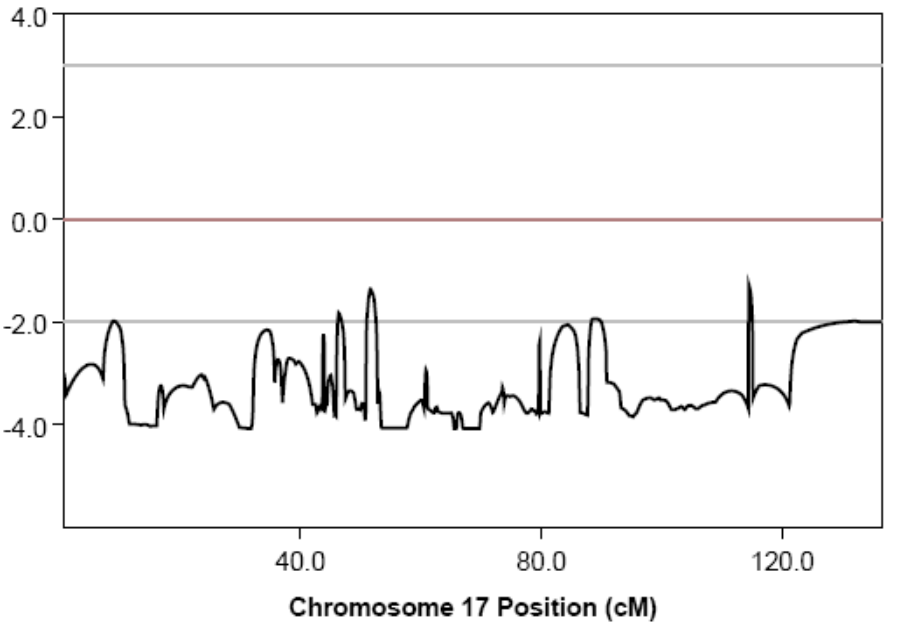

Parametric Analysis for Recessive_Model

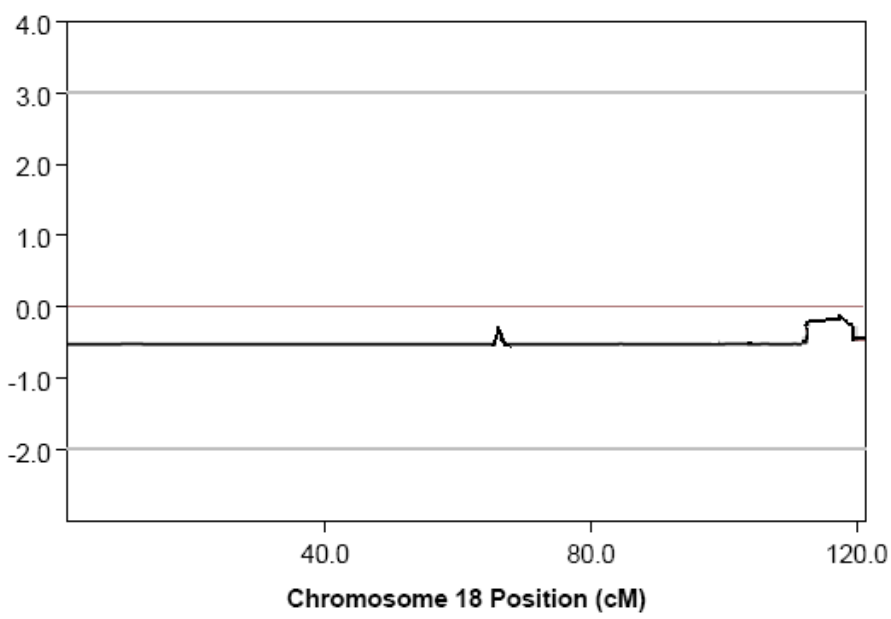

Parametric Analysis for Recessive_Model

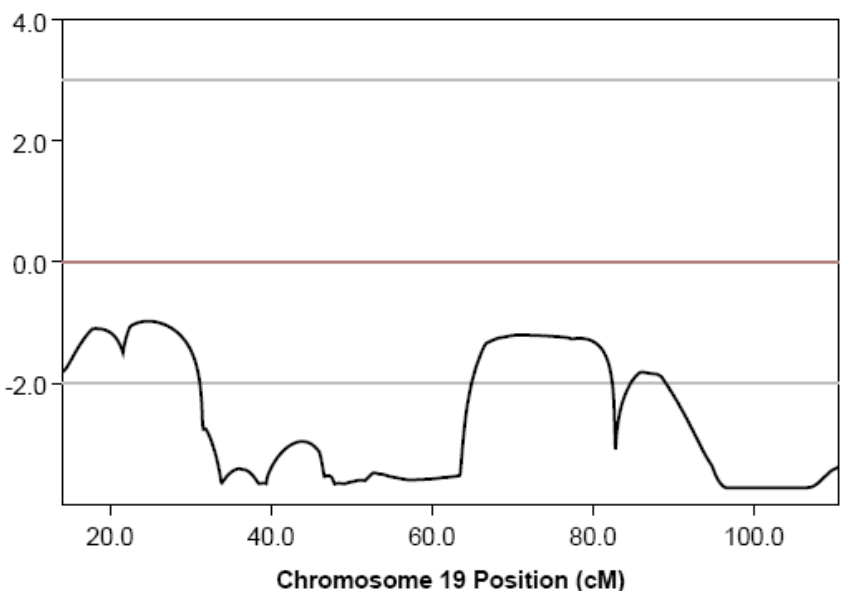

Figura 28 (continuação). Resultados dos lods scores de múltiplos pontos. 
Parametric Analysis for Dominant_Model

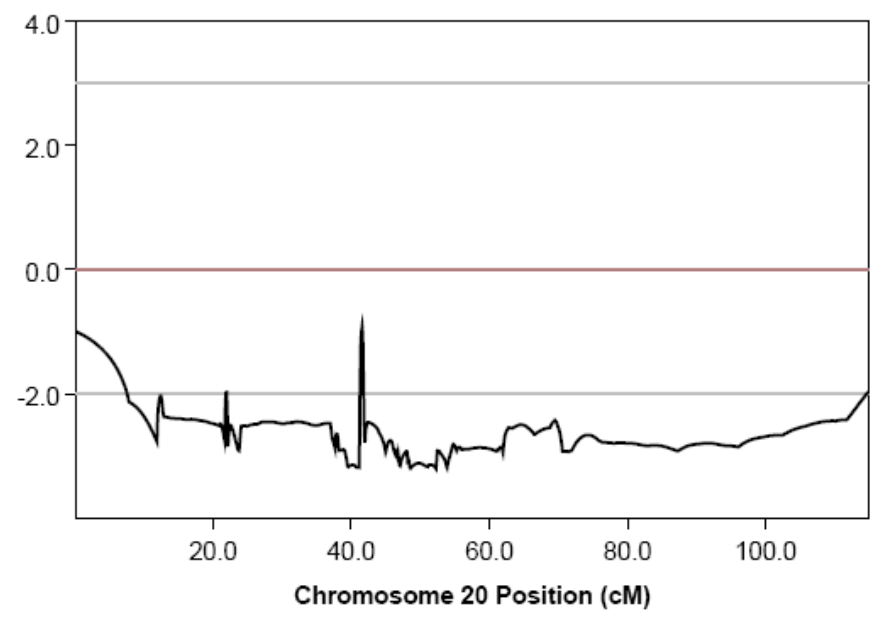

Parametric Analysis for Dominant_Model

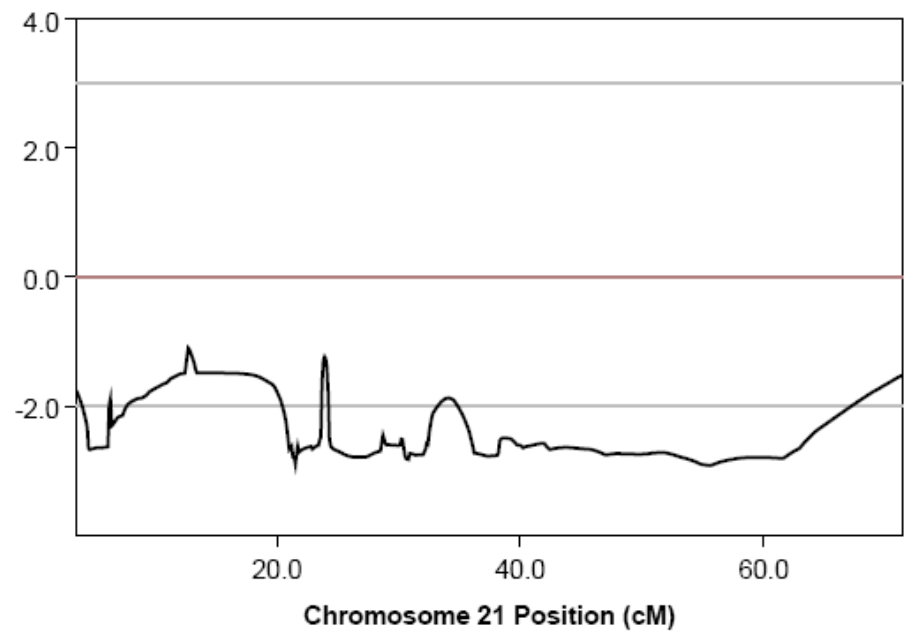

Parametric Analysis for Dominant_Model

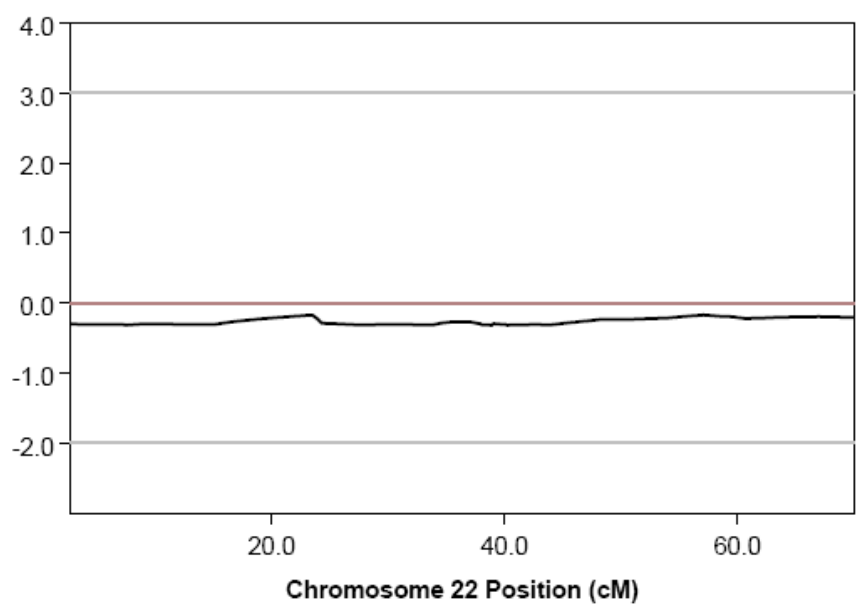

Parametric Analysis for Recessive_Model

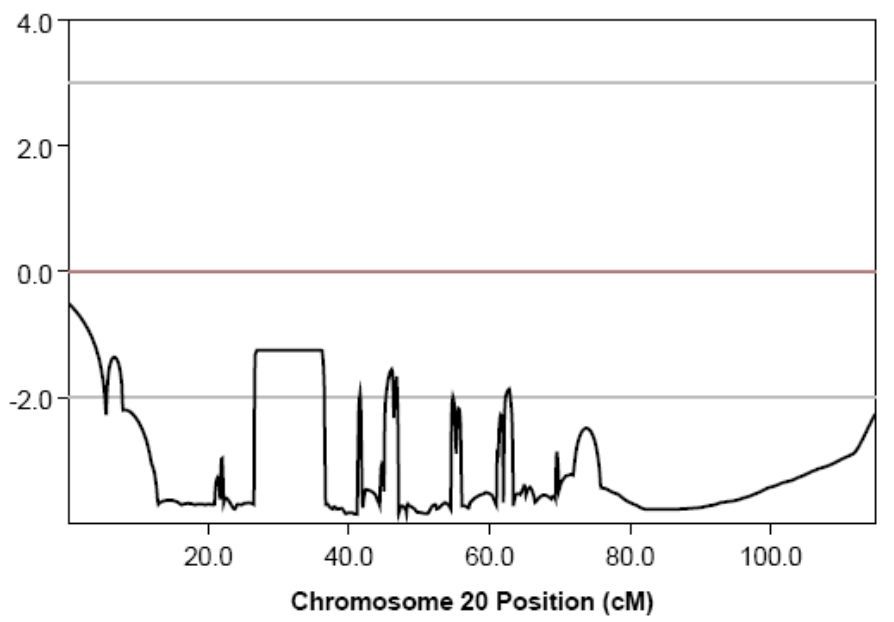

Parametric Analysis for Recessive_Model

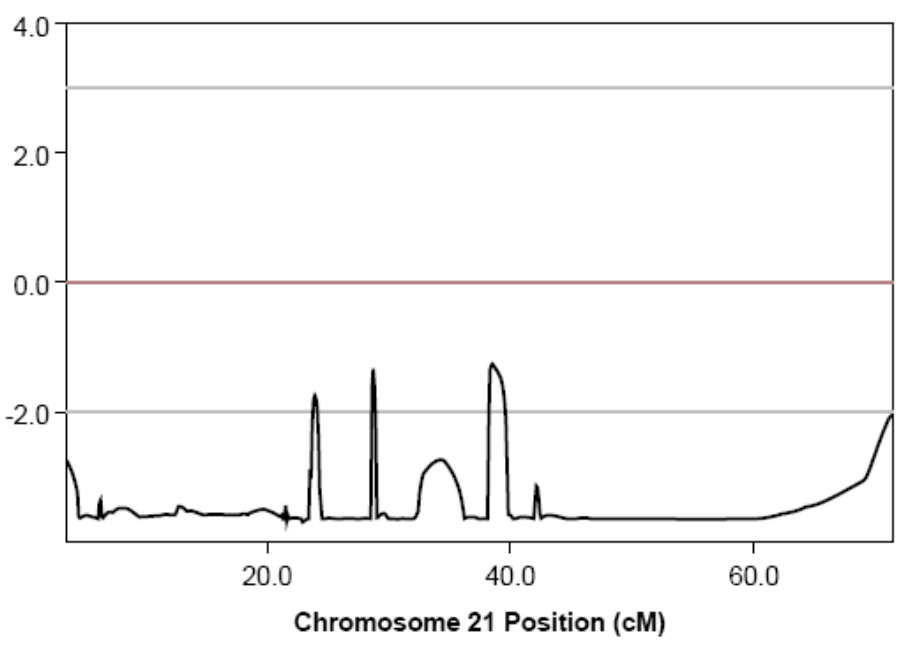

Figura 28 (continuação). Resultados dos lods scores de múltiplos pontos. 
Não foi possível obter resultados nos cromossomos 3, 6, 12, 14, 15 e 22 para a herança recessiva devido a problemas com pacote estatístico utilizado. Escreveu-se para Dr. Gonçalo Abecassis da Universidade de Michigan (criador do software) para pedir auxílio e estamos aguardando respostas. As análises de ligação com SNPs dos cromossomos $1,2,4,7,8,9,12,17,18,19,20$ e 21 mostradas na Figura 28, permitiram a exclusão completa de ligação com esses cromossomos, tanto no padrão de herança dominante, como no padrão de herança recessivo. Já em relação aos cromossomos 5,6,10,11 e 13 não obtivemos lod scores positivos acima de 3,00 indicativos de ligação, mas não é possível a exclusão desses cromossomos, já que os lod scores chegaram a mostrar valores positivos e sugestivos em algumas regiões desses cromossomos em ambos os padrões de herança, exceto no cromossomo 11 em que essa sugestão de ligação ocorreu apenas no modelo dominante. Nesses cromossomos foram então selecionados microssatélites próximos às regiões que apresentaram um lod score sugestivo de ligação, para aprofundamento dos estudos de ligação.

O cromossomo 16 apresentou lod scores positivos e sugestivos de ligação no padrão de herança recessivo. Entretanto, como o pico de lod score era muito estreito consideramos esse resultado um artefato. Portanto, não se investigou possível ligação com microssatélites.

Para a procura de evidências de ligação com o cromossomo 5 foram utilizados três marcadores moleculares que flanqueiam a região sugestiva de ligação (D5S2115, D5S436 e D5S410), para o cromossomo 6 foram utilizados 3 marcadores (D6S434, D6S287 e D6S262), para o cromossomo 10 foram utilizados 2 marcadores (D10S249 e D10S591), para o cromossomo 11 foram utilizados 4 marcadores (D11S935, D11S905, D11S4191 e D11S987) e para o cromossomo 13 foram utilizados 4 marcadores (D13S175, D13S217, D13S171 e D13S218). 
Com os genótipos correspondentes a esses marcadores construímos os haplótipos dos microssatélites das quatro regiões cromossômicas em questão (Figuras 29, 30,31, 32 e 33). Os lod scores de dois pontos foram calculados e estão apresentados nas Tabelas 12, 13,14, 15 e 16. Realizou-se o cálculo de lod scores de múltiplos pontos com o auxílio do programa Merlin. O resultado da análise de múltiplos pontos para as cinco regiões candidatas está apresentado nas Figuras 34, 35, 36 e 37. 


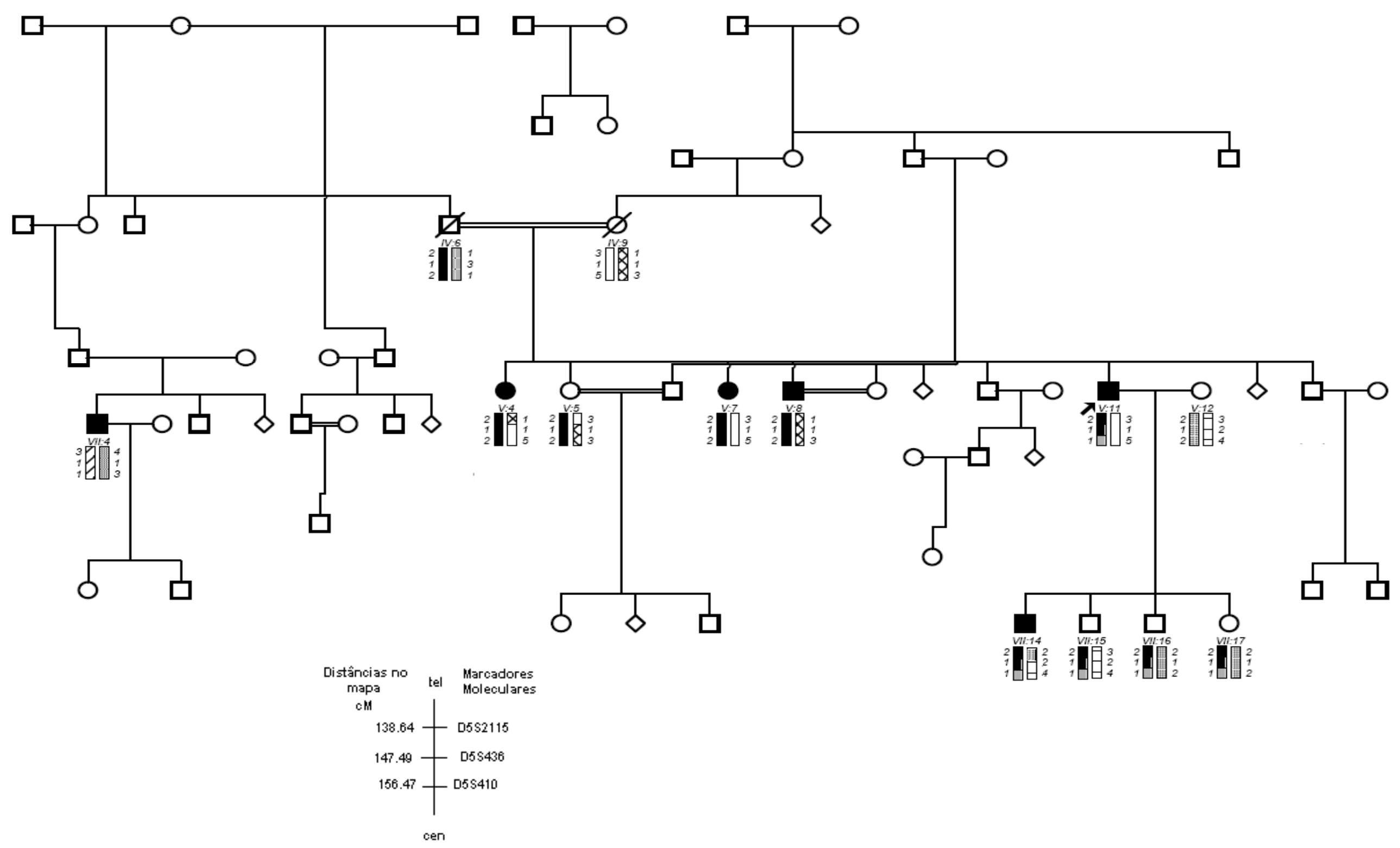

Figura 29. Heredograma da família 2 mostrando os haplótipos da região 5p15.33. Os indivíduos assinalados em preto são afetados por um quadro clínico variado de malformações de mãos e pés, incluindo aplasia/hipoplasia fibular. 


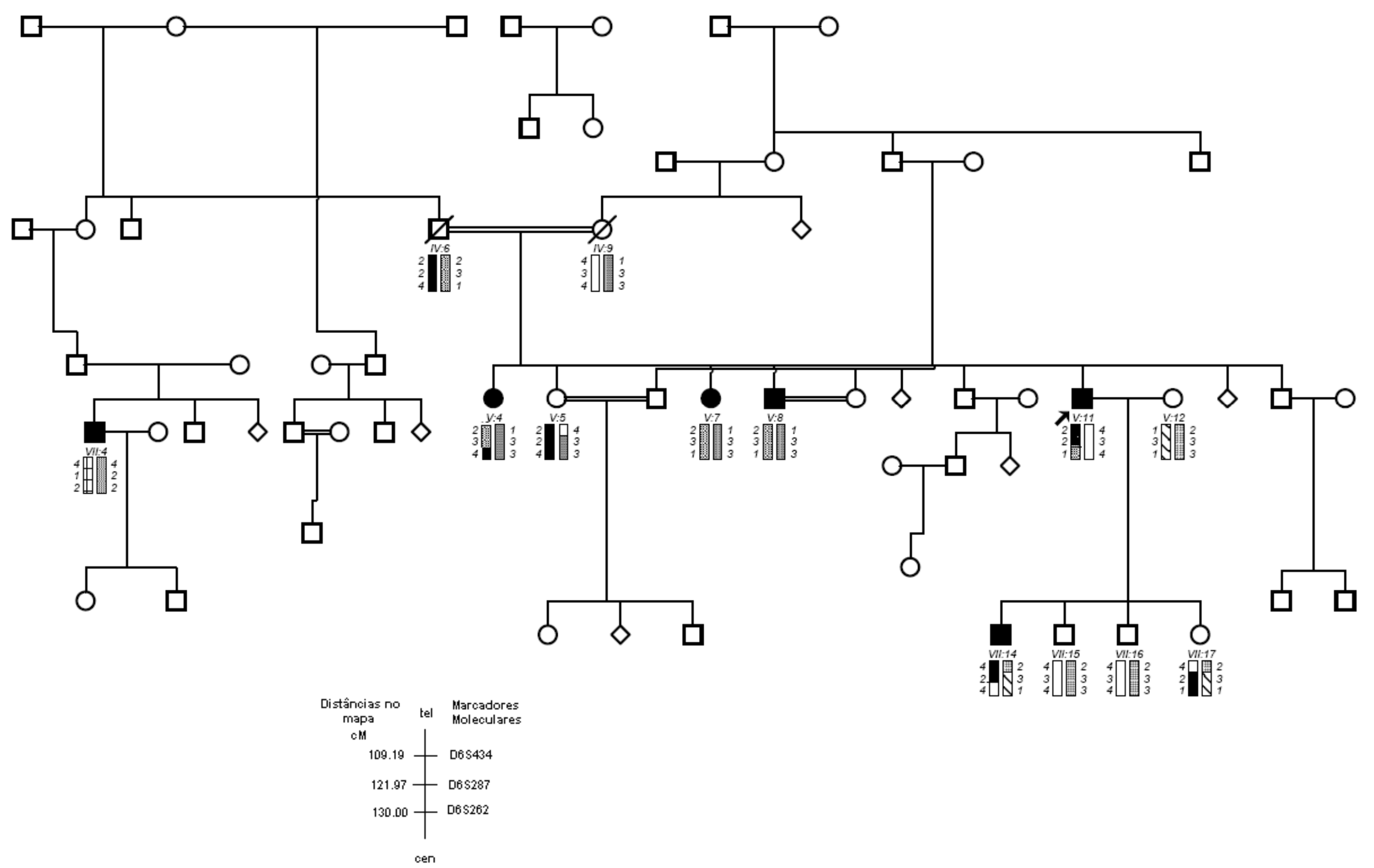

Figura 30. Heredograma da família 2 mostrando os haplótipos da região 6p25.3. Os indivíduos assinalados em preto 


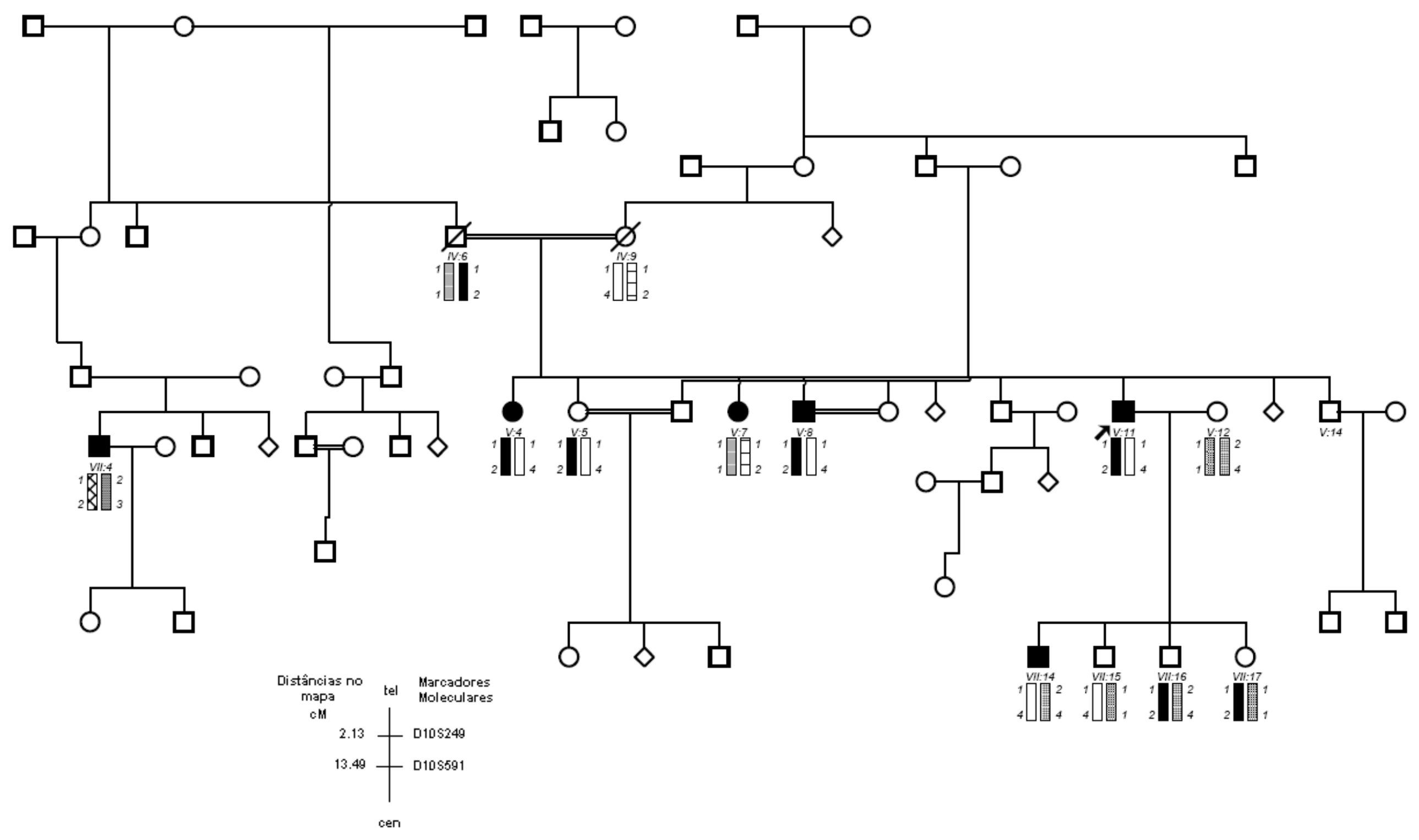

Figura 31. Heredograma da família 2 mostrando os haplótipos da região 10p15.3. Os indivíduos assinalados em preto são afetados por um quadro clínico variado de malformações de mãos e pés, incluindo aplasia/hipoplasia fibular. 


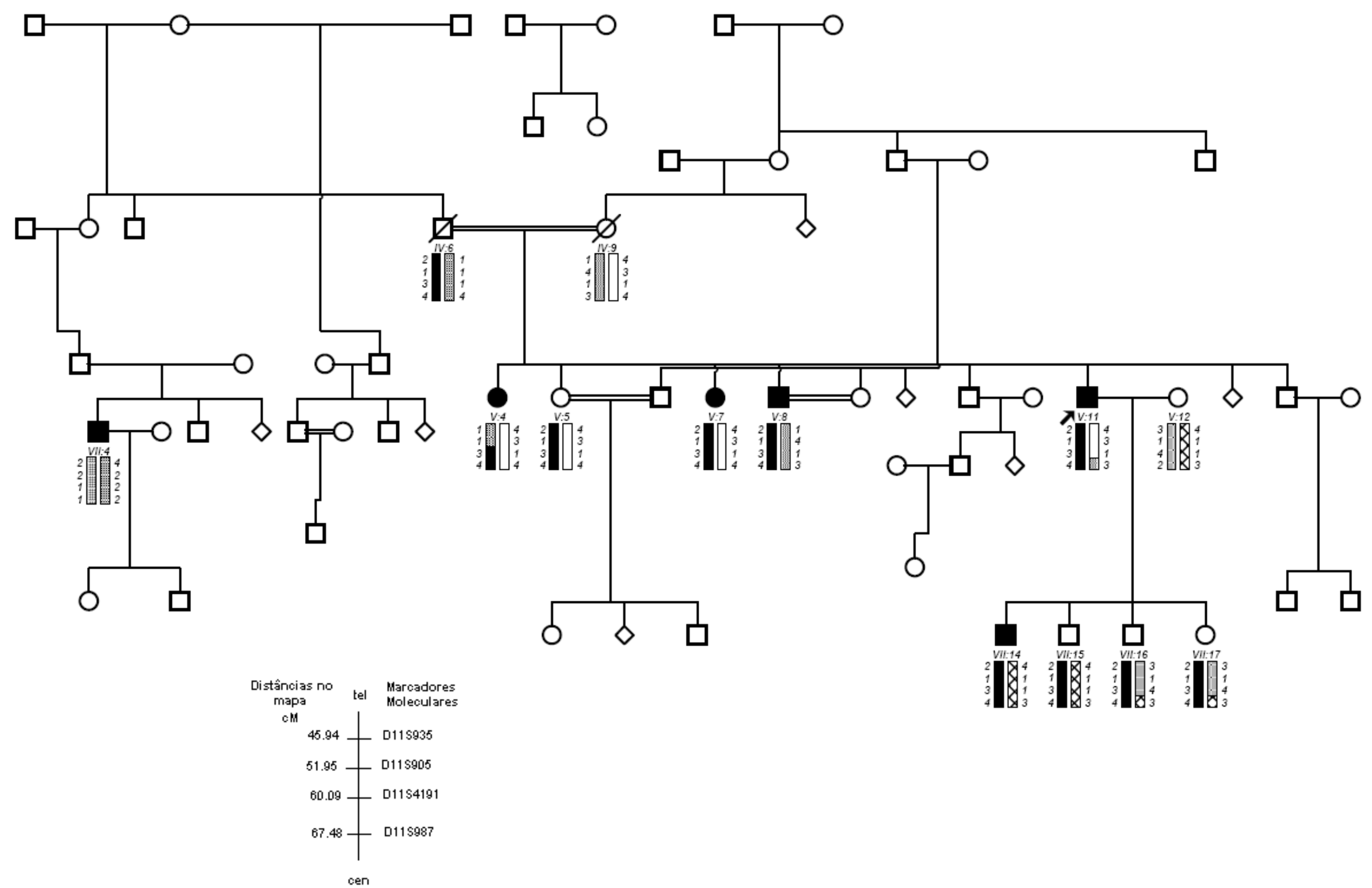

Figura 32. Heredograma da família 2 mostrando os haplótipos da região 11p15.5. Os indivíduos assinalados em preto são afetados por um quadro clínico variado de malformações de mãos e pés, incluindo aplasia/hipoplasia fibular. 


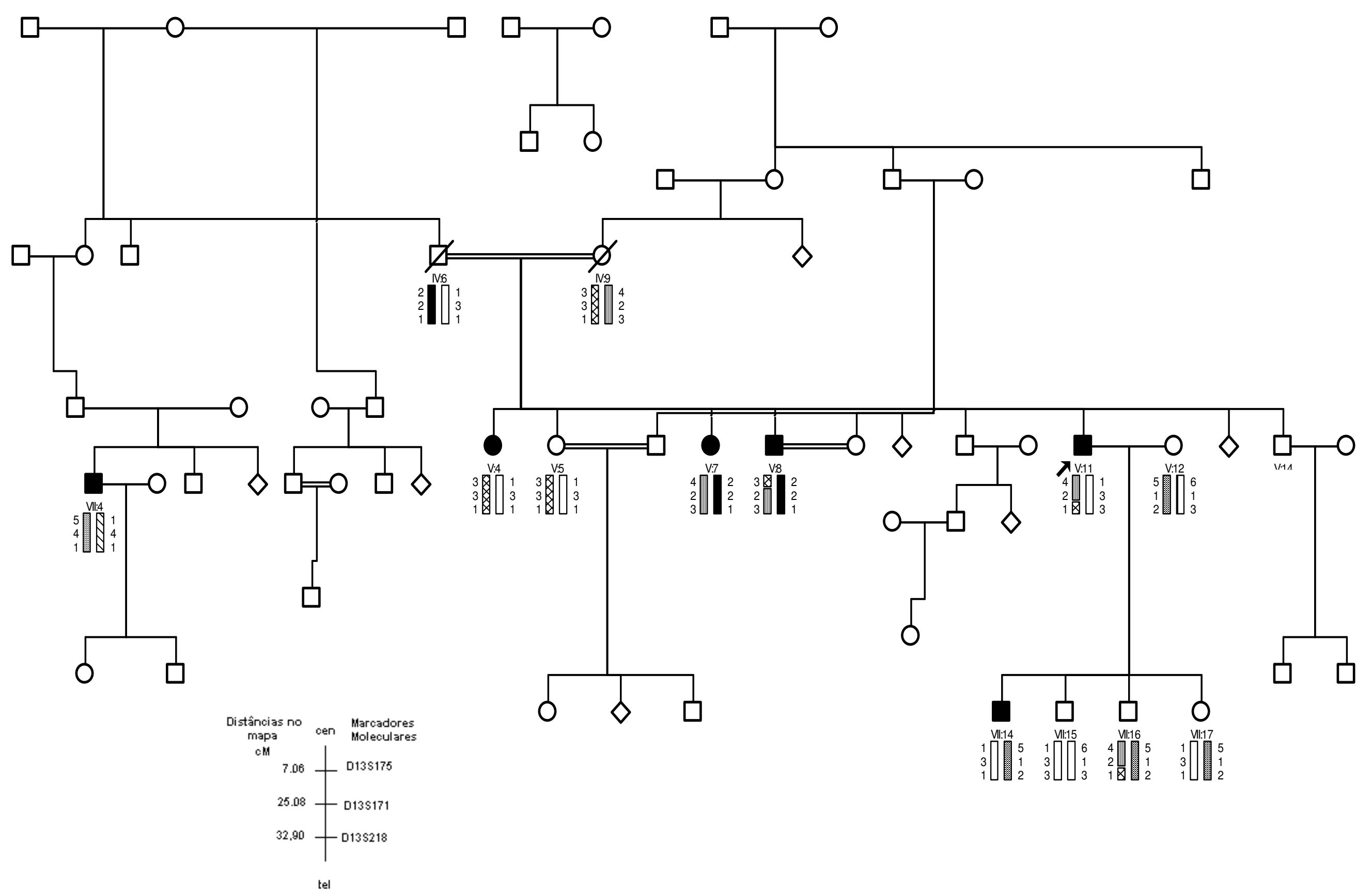

Figura 33. Heredograma da família 2 mostrando os haplótipos da região 13q12.11. Os indivíduos assinalados em preto são afetados por um quadro clínico variado de malformações de mãos e pés, incluindo aplasia/hipoplasia fibular. 
Tabela 12: Lod scores de dois pontos calculados com o programa MLINK do pacote FASTLINK em relação aos microssatélites da região cromossômica 5p15.33. O dois modelos de herança autossômica foram utilizados para a realização do calculo. (A) Herança autossômica dominante e (B) Herança autossômica recessiva

(A)

\begin{tabular}{|l|l|l|l|l|l|l|l|}
\cline { 2 - 9 } \multicolumn{1}{c|}{} & \multicolumn{7}{c|}{ Frações de recombinação } \\
\hline Microssatélites & $\mathbf{0 , 0 0}$ & $\mathbf{0 , 0 1}$ & $\mathbf{0 , 0 5}$ & $\mathbf{0 , 1}$ & $\mathbf{0 , 2}$ & $\mathbf{0 , 3}$ & $\mathbf{0 , 4}$ \\
\hline D5S2115 & 0.62 & 0.61 & 0.54 & 0.46 & 0.28 & 0.12 & 0.02 \\
\hline D5S436 & 0.72 & 0.70 & 0.63 & 0.54 & 0.36 & 0.19 & 0.05 \\
\hline D5S410 & -3.55 & -1.45 & -0.72 & -0.42 & -0.15 & -0.04 & -0.009 \\
\hline
\end{tabular}

(B)

\begin{tabular}{|l|l|l|l|l|l|l|l|}
\cline { 2 - 8 } \multicolumn{1}{c|}{} & \multicolumn{7}{c|}{ Frações de recombinação } \\
\hline Microssatélites & $\mathbf{0 , 0 0}$ & $\mathbf{0 , 0 1}$ & $\mathbf{0 , 0 5}$ & $\mathbf{0 , 1}$ & $\mathbf{0 , 2}$ & $\mathbf{0 , 3}$ & $\mathbf{0 , 4}$ \\
\hline D5S2115 & -infini & -3.49 & -1.50 & -0.74 & -0.16 & 0.01 & 0.02 \\
\hline D5S436 & -infini & -0.10 & 0.46 & 0.59 & 0.53 & 0.33 & 0.11 \\
\hline D5S410 & -infini & -3.20 & -1.28 & -0.60 & -0.14 & -0.02 & -0.001 \\
\hline
\end{tabular}

Tabela 13: Lod scores de dois pontos calculados com o programa MLINK do pacote FASTLINK em relação aos microssatélites da região cromossômica 6p25.3. O dois modelos de herança autossômica foram utilizados para a realização do calculo. (A) Herança autossômica dominante e (B) Herança autossômica recessiva

(A)

\begin{tabular}{|l|l|l|l|l|l|l|l|}
\cline { 2 - 8 } \multicolumn{1}{c|}{} & \multicolumn{7}{c|}{ Frações de recombinação } \\
\hline Microssatélites & $\mathbf{0 . 0 0}$ & $\mathbf{0 . 0 1}$ & $\mathbf{0 . 0 5}$ & $\mathbf{0 . 1}$ & $\mathbf{0 . 2}$ & $\mathbf{0 . 3}$ & $\mathbf{0 . 4}$ \\
\hline D6S434 & -3.43 & -1.17 & -0.52 & -0.27 & -0.09 & -0.02 & -0.005 \\
\hline D6S287 & -3.13 & -0.94 & -0.32 & -0.11 & 0.007 & 0.018 & 0.006 \\
\hline D6S262 & -3.38 & -1.29 & -0.61 & -0.34 & -0.12 & -0.03 & -0.005 \\
\hline
\end{tabular}


(B)

\begin{tabular}{|l|l|l|l|l|l|l|l|}
\cline { 2 - 8 } \multicolumn{1}{c|}{} & \multicolumn{7}{c|}{ Frações de recombinação } \\
\hline Microssatélites & $\mathbf{0 . 0 0}$ & $\mathbf{0 . 0 1}$ & $\mathbf{0 . 0 5}$ & $\mathbf{0 . 1}$ & $\mathbf{0 . 2}$ & $\mathbf{0 . 3}$ & $\mathbf{0 . 4}$ \\
\hline D6S434 & -infini & -2.09 & -0.81 & -0.35 & -0.04 & 0.015 & 0.009 \\
\hline D6S287 & -infini & -0.98 & -0.35 & -0.12 & 0.010 & 0.02 & 0.010 \\
\hline D6S262 & -infini & -3.20 & -1.28 & -0.60 & -0.14 & -0.022 & -0.001 \\
\hline
\end{tabular}

Tabela 14: Lod scores de dois pontos calculados com o programa MLINK do pacote FASTLINK em relação aos microssatélites da região cromossômica 10p15.3. O dois modelos de herança autossômica foram utilizados para a realização do cálculo. (A) Herança autossômica dominante e (B) Herança autossômica recessiva

(A)

\begin{tabular}{|l|l|l|l|l|l|l|l|}
\cline { 2 - 8 } \multicolumn{1}{c|}{} & \multicolumn{7}{c|}{ Frações de recombinação } \\
\hline Microssatélites & $\mathbf{0 , 0 0}$ & $\mathbf{0 , 0 1}$ & $\mathbf{0 , 0 5}$ & $\mathbf{0 , 1}$ & $\mathbf{0 , 2}$ & $\mathbf{0 , 3}$ & $\mathbf{0 , 4}$ \\
\hline D13S249 & $-2,21$ & -1.17 & -0.91 & -0.55 & -0.33 & -0.08 & -0.02 \\
\hline D10S591 & -2.97 & -1.13 & -0.49 & -0.25 & -0.08 & -0.02 & -0.004 \\
\hline
\end{tabular}

(B)

\begin{tabular}{|l|l|l|l|l|l|l|l|}
\cline { 2 - 8 } \multicolumn{1}{c|}{} & \multicolumn{7}{c|}{ Frações de recombinação } \\
\hline Microssatélites & $\mathbf{0 , 0 0}$ & $\mathbf{0 , 0 1}$ & $\mathbf{0 , 0 5}$ & $\mathbf{0 , 1}$ & $\mathbf{0 , 2}$ & $\mathbf{0 , 3}$ & $\mathbf{0 , 4}$ \\
\hline D10S249 & -infini & -1.10 & -0.46 & -0.22 & -0.06 & -0.01 & -0.00 \\
\hline D10S591 & -infini & -4.90 & -2.25 & -1.24 & -0.43 & -0.13 & -0.02 \\
\hline
\end{tabular}


Tabela 15: Lod scores de dois pontos calculados com o programa MLINK do pacote FASTLINK em relação aos microssatélites da região cromossômica $11 \mathrm{p} 15.5$. O dois modelos de herança autossômica foram utilizados para a realização do cálculo. (A) Herança autossômica dominante e (B) Herança autossômica recessiva

(A)

\begin{tabular}{|l|l|l|l|l|l|l|l|}
\cline { 2 - 8 } \multicolumn{1}{c|}{} & \multicolumn{7}{c|}{ Frações de recombinação } \\
\hline Microssatélites & $\mathbf{0 , 0 0}$ & $\mathbf{0 , 0 1}$ & $\mathbf{0 , 0 5}$ & $\mathbf{0 , 1}$ & $\mathbf{0 , 2}$ & $\mathbf{0 , 3}$ & $\mathbf{0 , 4}$ \\
\hline D11S935 & -3.31 & -1.45 & -0.75 & -0.45 & -0.18 & -0.06 & -0.01 \\
\hline D11S905 & -0.10 & -0.10 & -0.10 & -0.09 & -0.05 & -0.02 & -0.006 \\
\hline D11S4191 & 0.53 & 0.52 & 0.47 & 0.41 & 0.27 & 0.14 & 0.03 \\
\hline D11S987 & -0.27 & -0.27 & -0.26 & -0.24 & -0.17 & -0.08 & -0.02 \\
\hline
\end{tabular}

Tabela 16: Lod scores de dois pontos calculados com o programa MLINK do pacote FASTLINK em relação aos microssatélites da região cromossômica 13q12.11. O dois modelos de herança autossômica foram utilizados para a realização do calculo. (A) Herança autossômica dominante e (B) Herança autossômica recessiva

(A)

\begin{tabular}{|l|l|l|l|l|l|l|l|}
\cline { 2 - 8 } \multicolumn{1}{c|}{} & \multicolumn{7}{c|}{ Frações de recombinação } \\
\hline Microssatélites & $\mathbf{0 , 0 0}$ & $\mathbf{0 , 0 1}$ & $\mathbf{0 , 0 5}$ & $\mathbf{0 , 1}$ & $\mathbf{0 , 2}$ & $\mathbf{0 , 3}$ & $\mathbf{0 , 4}$ \\
\hline D13S175 & $-2,21$ & -1.31 & -0.96 & -0.52 & -0.33 & -0.05 & -0.02 \\
\hline D13S171 & -2.93 & -1.17 & -0.55 & -0.25 & -0.05 & -0.02 & -0.004 \\
\hline D13S218 & -2.17 & -1.11 & -0.77 & -0.43 & -0.21 & -0.05 & -0.02 \\
\hline
\end{tabular}


(B)

\begin{tabular}{|l|l|l|l|l|l|l|l|}
\cline { 2 - 8 } \multicolumn{1}{c|}{} & \multicolumn{7}{c|}{ Frações de recombinação } \\
\hline Microssatélites & $\mathbf{0 , 0 0}$ & $\mathbf{0 , 0 1}$ & $\mathbf{0 , 0 5}$ & $\mathbf{0 , 1}$ & $\mathbf{0 , 2}$ & $\mathbf{0 , 3}$ & $\mathbf{0 , 4}$ \\
\hline D13S175 & -infini & -2.29 & -2.01 & -1.93 & -1.27 & -0.51 & -0.15 \\
\hline D13S171 & -infini & -3.32 & -2.25 & -1.33 & -0.21 & -0.13 & -0.02 \\
\hline D13S218 & -infini & -4.41 & -3.57 & -2.21 & -1.22 & -0.87 & -0.21 \\
\hline
\end{tabular}

Parametric Analysis for Dominant_Model

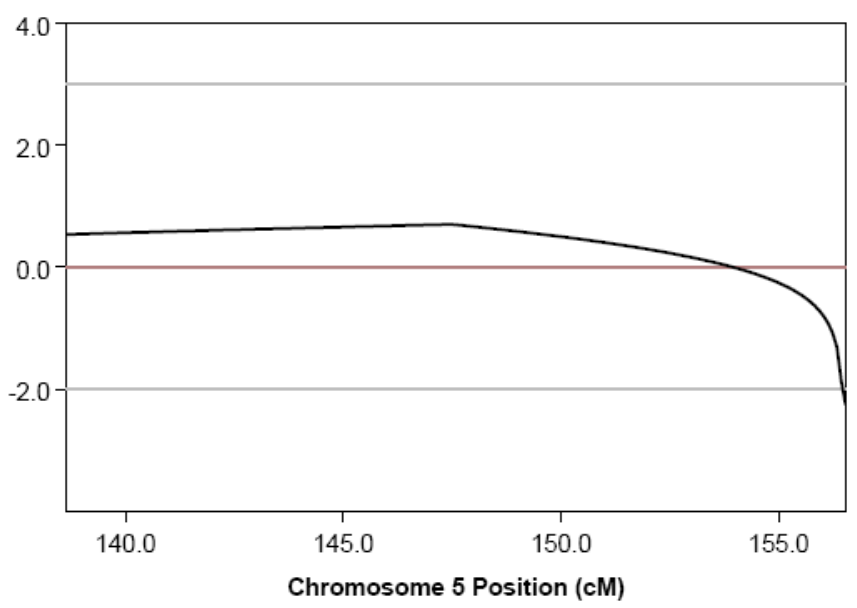

Parametric Analysis for Recessive_Model

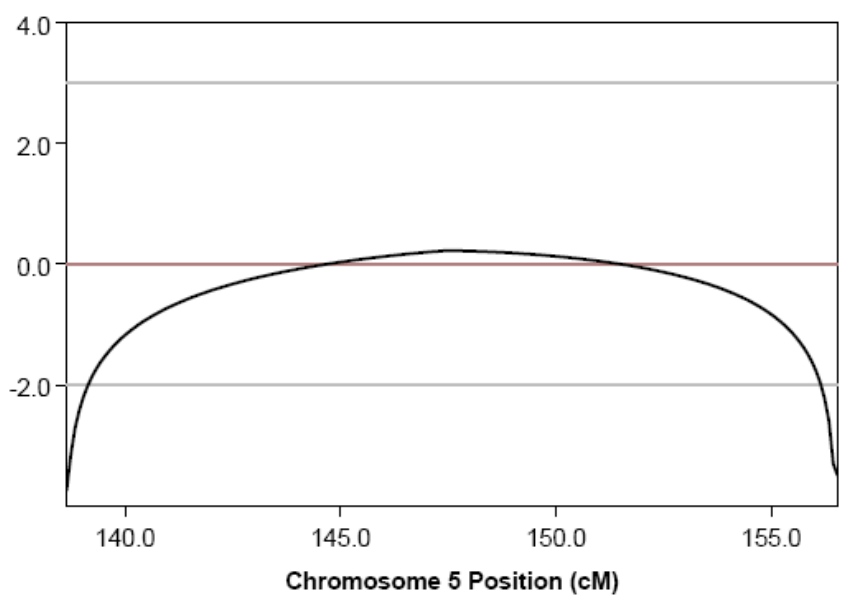

Figura 34. Resultados de lod scores de múltiplos pontos obtidos com os marcadores da região 5p15.33, utilizando os dois modelos de herança autossômica.
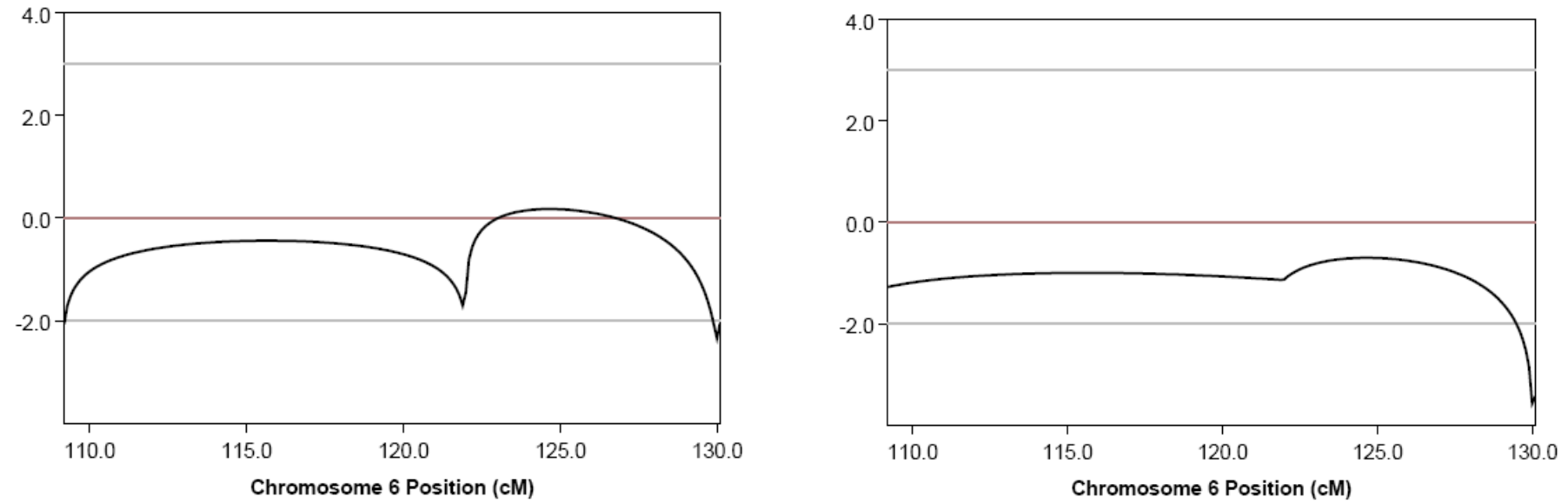

Figura 35. Resultados de lod scores de múltiplos pontos obtidos com os marcadores da região 6p25.3, utilizando os dois modelos de herança autossômica. 
Parametric Analysis for Dominant_Model

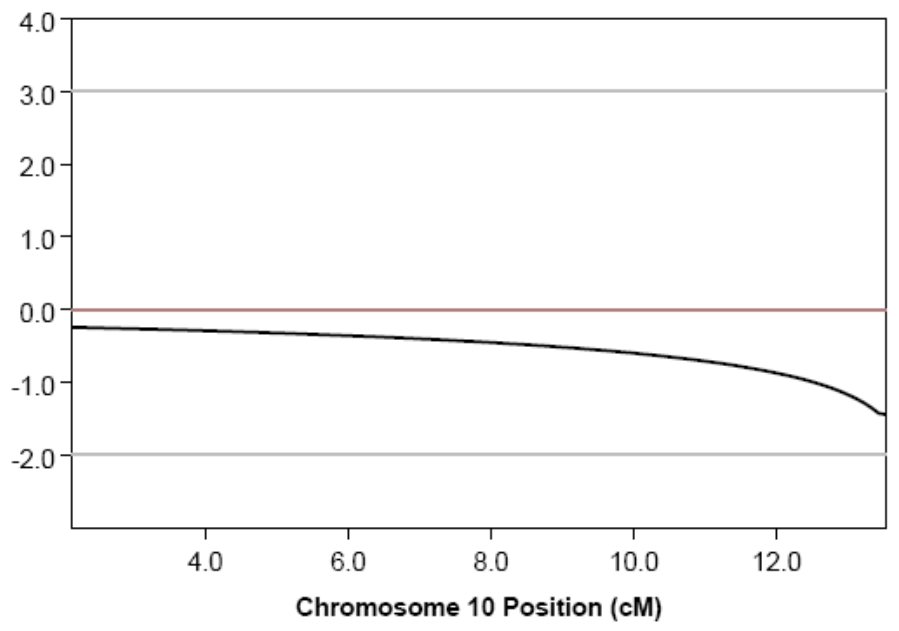

Parametric Analysis for Recessive_Model

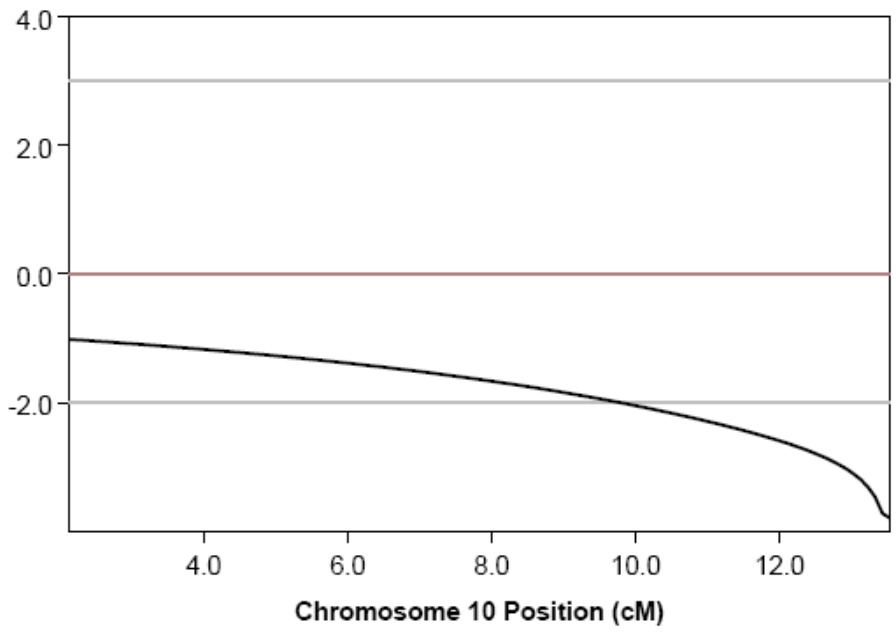

Figura 36. Resultados de lod scores de múltiplos pontos obtidos com os marcadores da região 10p15.3, utilizando os dois modelos de herança autossômica.

Parametric Analysis for Dominant_Model

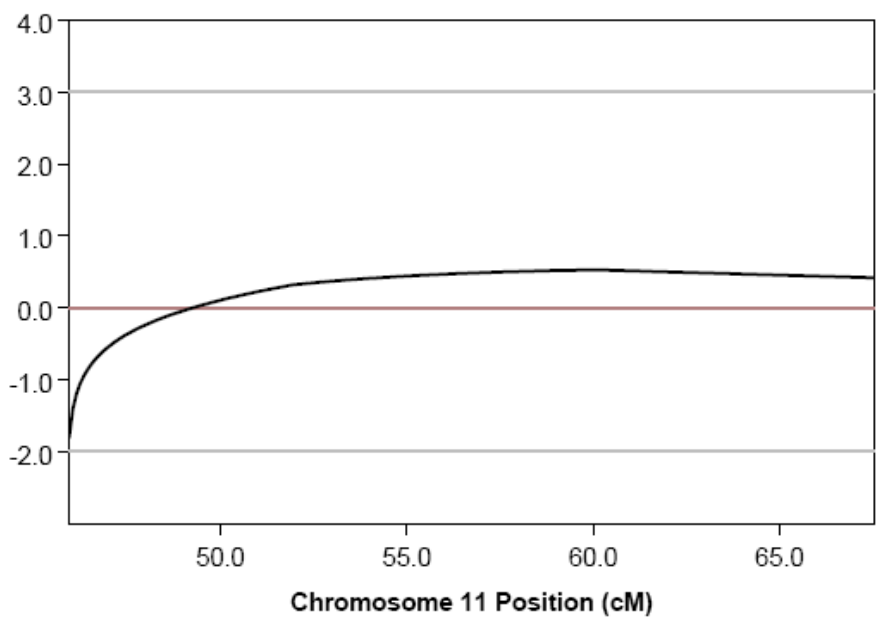

Figura 37. Resultados de lod scores de múltiplos pontos obtidos com os marcadores da região estudada no cromossomo 11p15, utilizando o modelo de herança autossômica dominante. 
Parametric Analysis for Dominant_Model

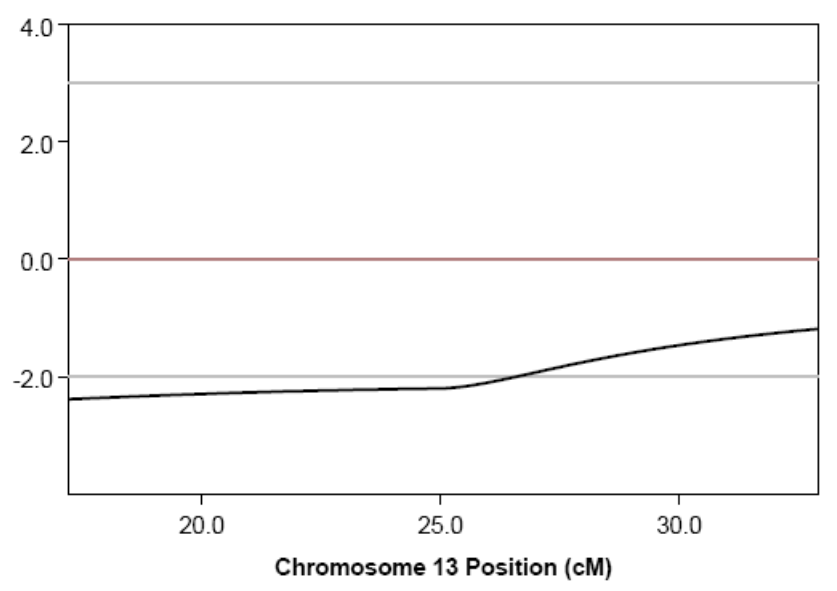

Parametric Analysis for Recessive_Model

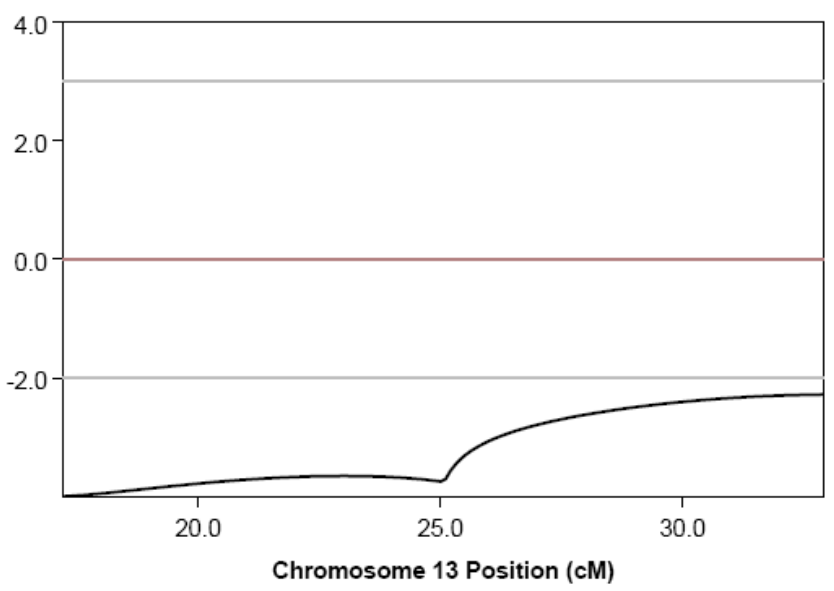

Figura 38. Resultados de lod scores de múltiplos pontos obtidos com os marcadores da região estudada no cromossomo 13q12.11, utilizando os dois modelos de herança autossômica.

A análise dos microssatélites nos cromossomos 6,10 e 13 não mostraram evidências de ligação, considerando-se a segregação dos haplótipos e os valores negativos dos lod scores obtidos nas análises paramétricas. Desse modo, as regiões analisadas dos cromossomos 6,10 e 13 são improváveis como candidatas a conter o gene responsável pela doença em questão. Já no cromossomo 11 os lods scores de múltiplos pontos atingiram o valor de 0.8 para a herança dominante, um valor positivo, mas não considerado significativo para se aceitar ligação. No cromossomo 5, não obtivemos lod scores positivos acima de 3,00, mas não foi possível a exclusão completa de ligação já que os lod scores de dois pontos chegaram a apresentar valores positivos em torno de 0.70 , enquanto o lod score de múltiplos pontos atingiu o valor de 0.967 (ambos para a herança dominante). Na literatura ainda não foram apontados genes candidatos 
relacionados a defeitos de membros nos cromossomos 5 e 11, o que sugere que a doença pode estar relacionada com algum gene inédito ainda não associado à malformação de membros. Em outras palavras, não há, no momento, bons genes candidatos a serem testados nos cromossomos 5 e 11 .

Os genes GDF5 (20q11) e TBX3 (12q24), identificados como sendo responsáveis pela aplasia/hipolasia fibular relacionados em síndromes bem distintas entre si e distintas dessa apresentada pela família 2 não foram testados, já que por meio da varredura gênomica de SNPs conseguiu-se eliminar o cromossomo 12 e o cromossomo 20 como possíveis candidatos a conter o gene responsável pela doença em questão.

Em paralelo a esses experimentos, recebemos em estudo colaborativo do grupo do Dr. Bernd Wollnik (Universidade Colônia, Alemanha) primers para sequenciamento de alguns genes que já foram descritos como relacionados a malformações de membros a fim de identificar possíveis mutações. Os genes sequenciados foram: $S H H$ (7q36), ZRS (7q36.3), WNT7a (3p25), WNT10b (12q13.11-q13) e GREM1 (15q13.3). Todos os exons foram sequenciados e não foi encontrada nenhuma mutação dentro desses cinco genes.

No futuro, planejamos realizar análises com mais microssatélites dos cromossomos 5 e 11 na tentativa de refinar o mapeamento, com o objetivo de chegarmos a uma região mais restrita com possíveis genes candidatos.

\subsection{Família 3}

A família 3 foi averiguada durante o projeto do laboratório sobre estudos genéticos nos remanescentes de quilombos, mais especificamente no projeto de Doutorado desenvolvido por Lilian Kimura (Kimura, 2010). 
A disponibilidade de material dessa família com três afetados, a possibilidade de encontrar mutações que corroborem estudos já publicados ou então a identificação de novos genes ou regiões cromossômicas associadas a defeitos de membros justificaram o desenvolvimento do estudo nessa família.

Os estudos moleculares nessa família também tiveram inicio com a realização de estudos de ligação utilizando marcadores moleculares do tipo microssatélites mapeados nas regiões cromossômicas 10q24, 7q21, 17p13, 3q27 e 2q31 descritas até o momento como regiões candidatas a conter genes responsáveis por defeitos de membros.

Com os mesmos marcadores do kit “ABI PRISM ${ }^{\circledR}$ Linkage Mapping Set v. 2.5-MD10” da Applied Biosystems utilizados na família 2, procuraram-se evidências de ligação com as cinco regiões candidatas. Com os genótipos correspondentes aos marcadores construímos os haplótipos das cinco regiões cromossômicas em questão (Figura 39, 40, 41, 42 e 43). Os lod scores de dois pontos foram calculados e estão apresentados nas Tabelas 17, 18, 19, 20 e 21 . Realizou-se o cálculo de lod scores de múltiplos pontos com o auxílio do programa Merlin. O resultado da análise de múltiplos pontos para as regiões candidatas $(10 \mathrm{q} 24,17 \mathrm{p} 13.3-17 \mathrm{p} 13,7 \mathrm{q} 21,3 \mathrm{q} 27$ e 2q31) está apresentado nas Figuras 44, 45, 46, 47 e 48. 


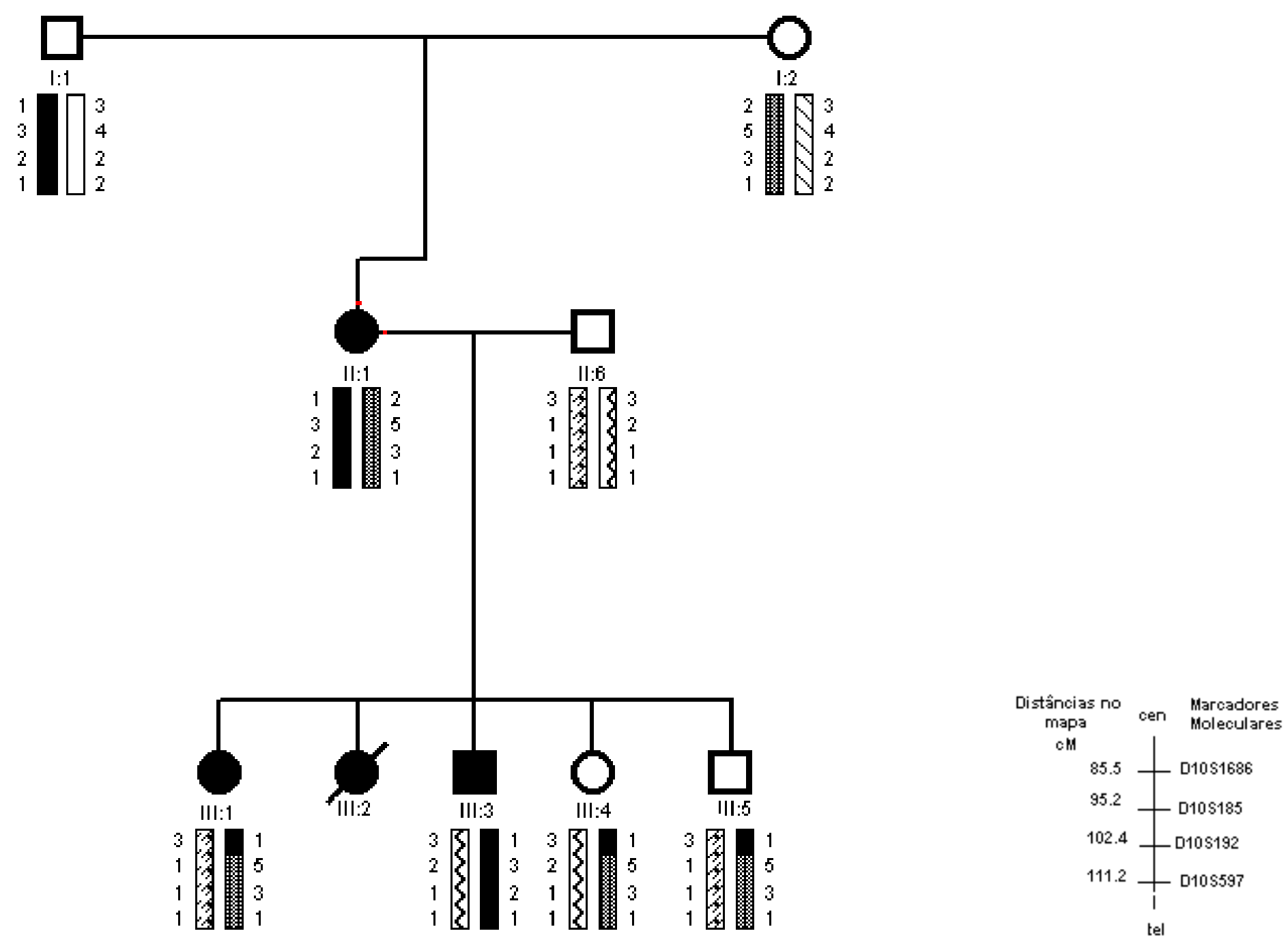

Figura 39.Heredograma da família 3 mostrando os haplótipos da região cromossômica 10q24. Os indivíduos assinalados em preto são afetados por um quadro variável de defeitos de membros entre eles polissindactilia, sindactilia, camptodactilia e defeitos ungueais. 

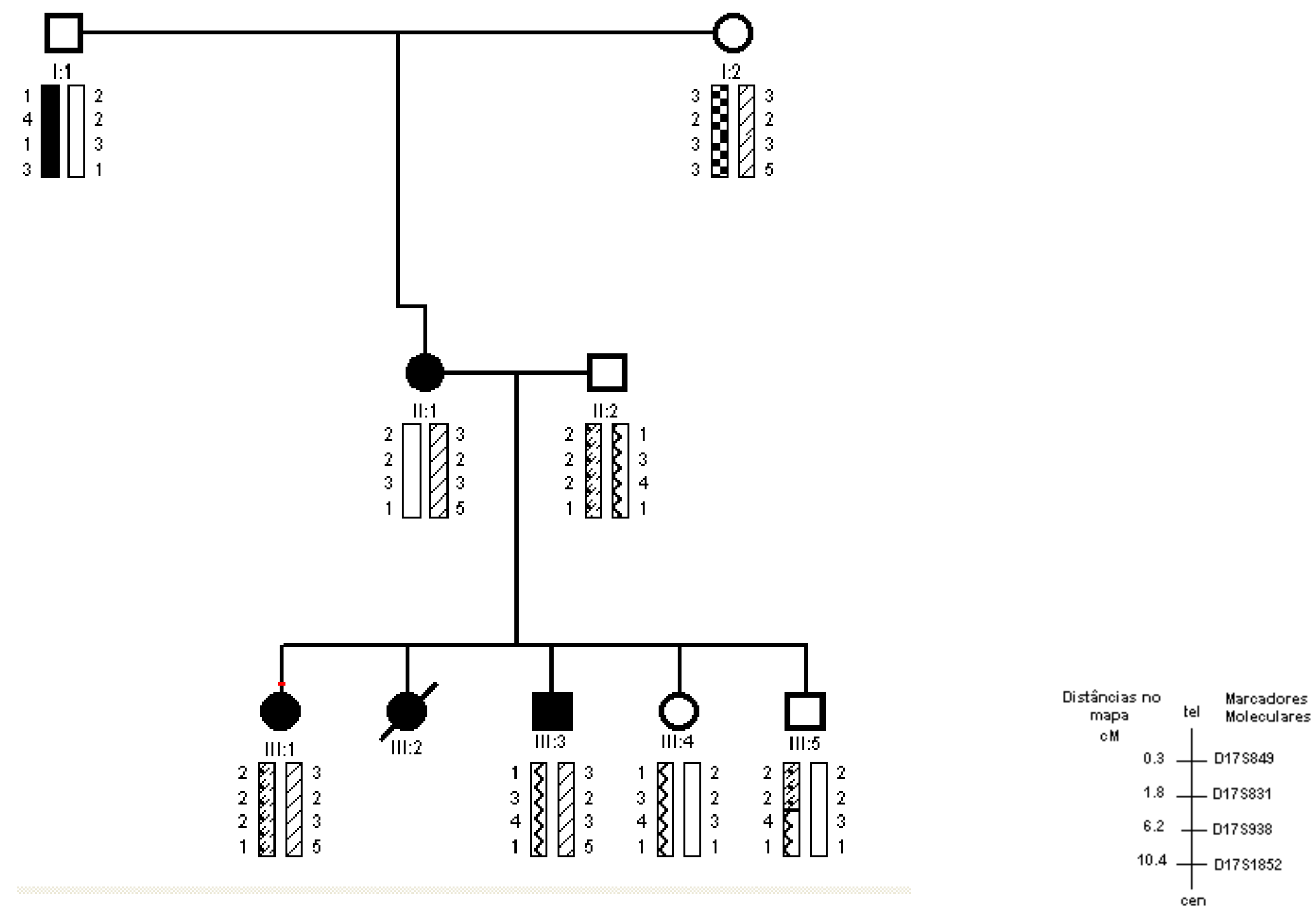

Figura 40.Heredograma da família 3 mostrando os haplótipos da região cromossômica 17p13.3-17p13. Os indivíduos assinalados em preto são afetados por um quadro variável de defeitos de membros entre eles polissindactilia, sindactilia, camptodactilia e defeitos ungueais. 

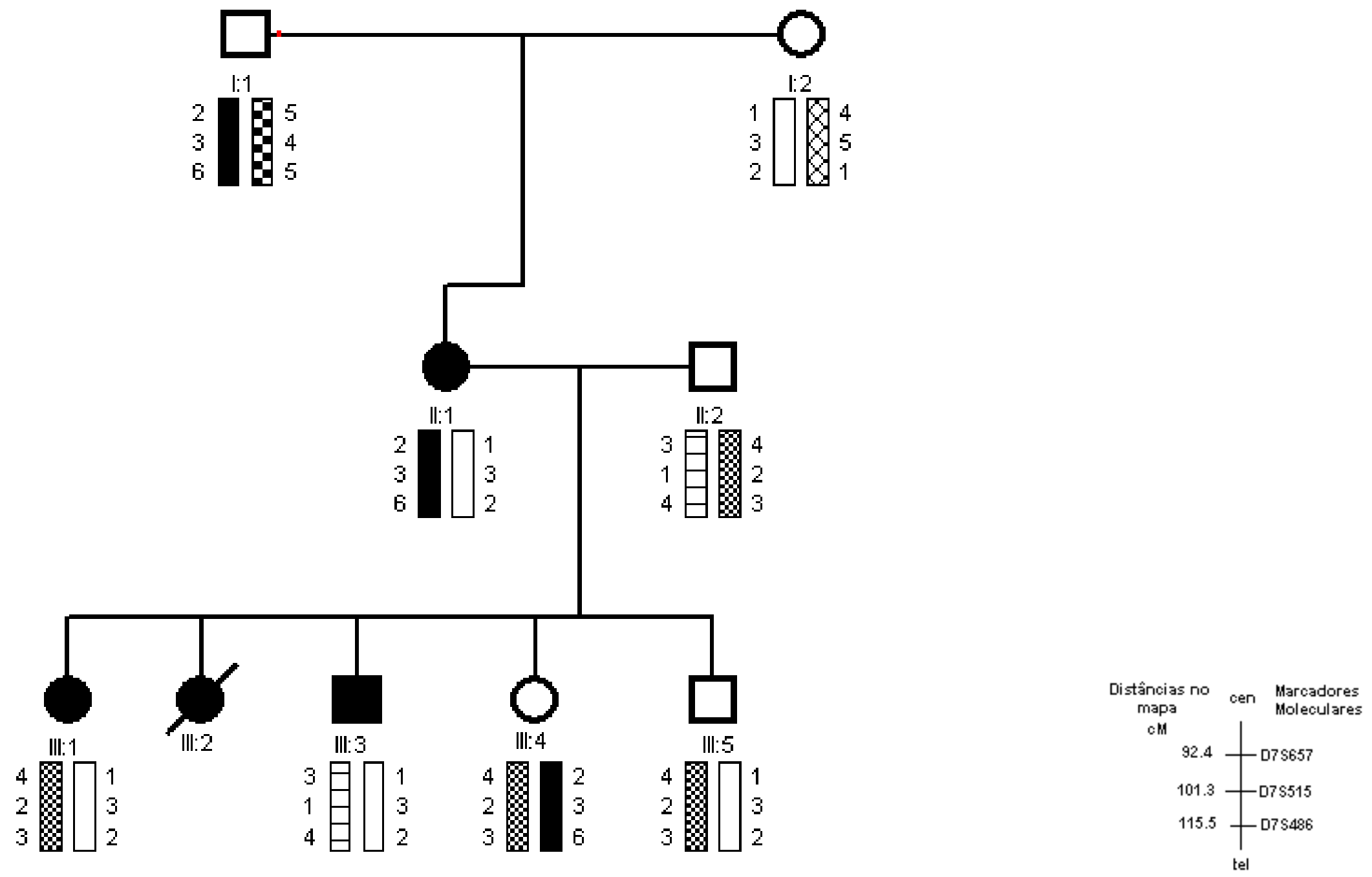

Figura 41.Heredograma da família 3 mostrando os haplótipos da região cromossômica 7q21. Os indivíduos assinalados em preto são afetados por um quadro variável de defeitos de membros entre eles polissindactilia, sindactilia, camptodactilia e defeitos ungueais. 


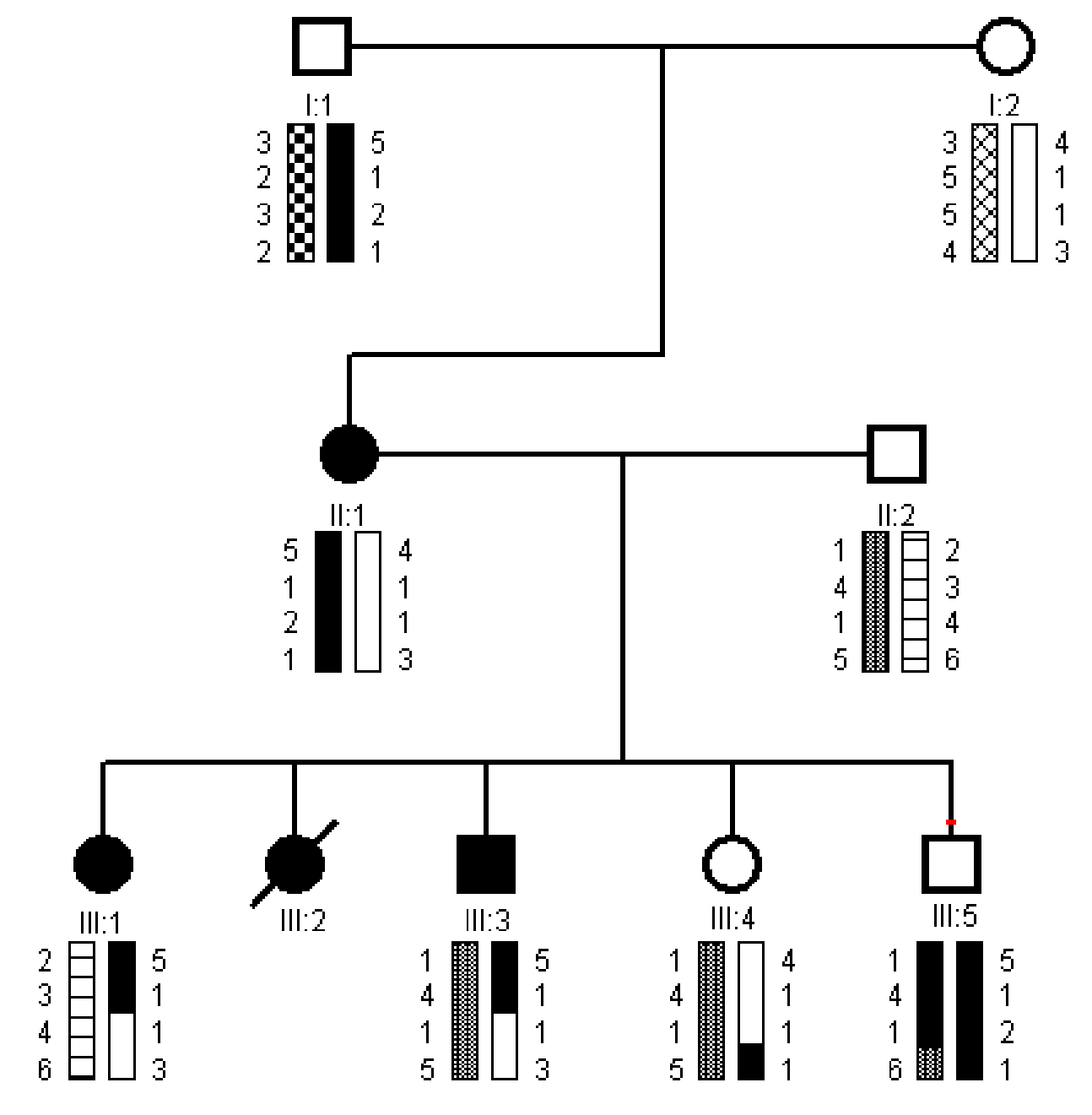

Figura 42.Heredograma da família 3 mostrando os haplótipos da região cromossômica 3q27. Os indivíduos assinalados em preto sao atetados por um quadro variável de defeitos de membros entre eles polissindactilia, sindactilia, camptodactilia e defeitos ungueais. 


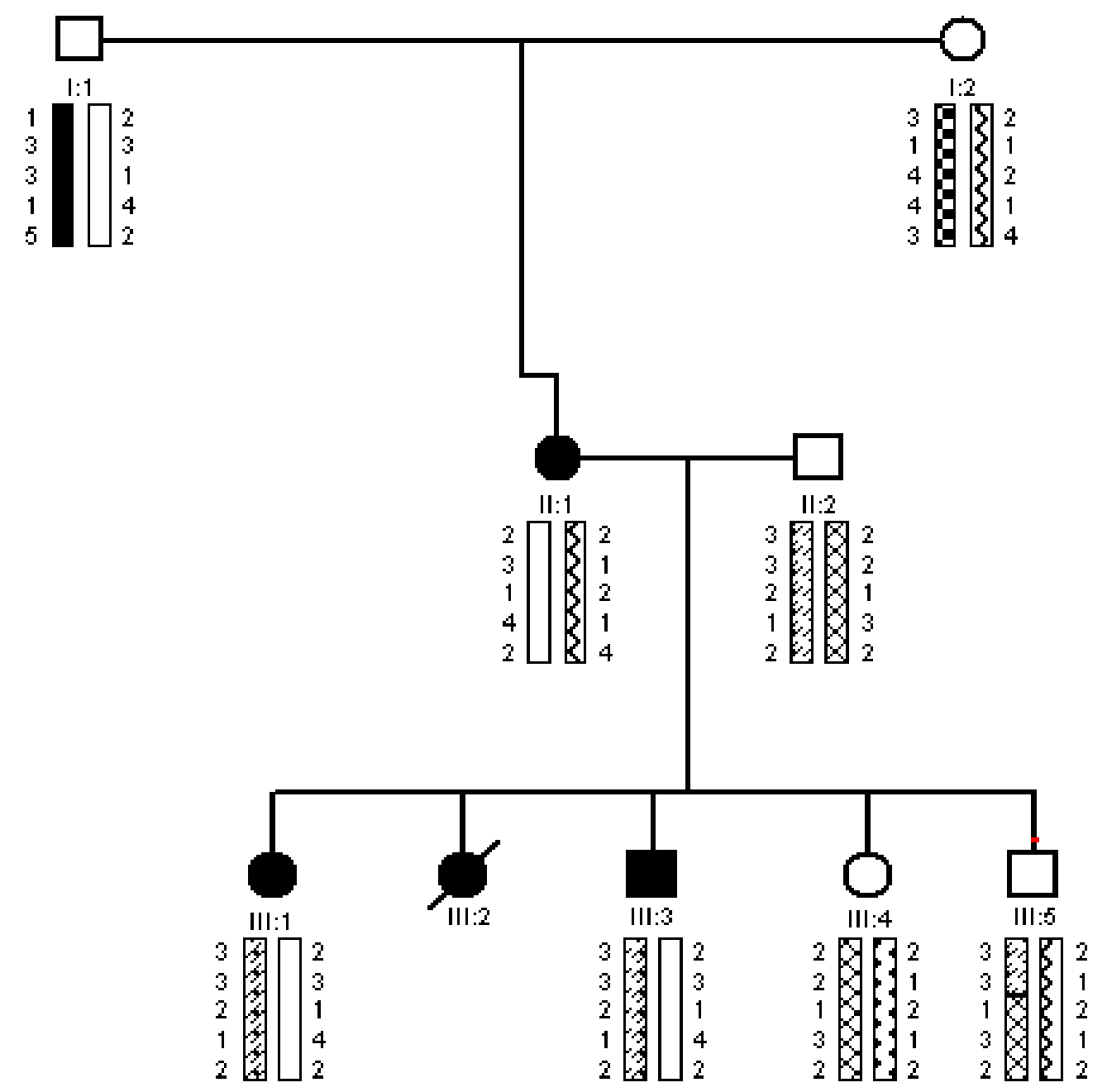

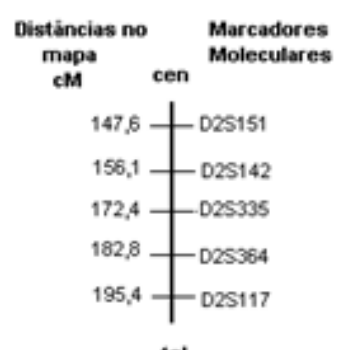

tel

Figura 43. Heredograma da família 3 mostrando os haplótipos da região cromossômica 2q31. Os indivíduos assinalados em preto são afetados por um quadro variável de defeitos de membros entre eles polissindactilia, sindactilia, camptodactilia e defeitos ungueais. 
Tabela 17: Lod scores de dois pontos calculados com o programa MLINK do pacote FASTLINK em relação aos microssatélites da região cromossômica 10q24.

\begin{tabular}{|l|l|l|l|l|l|l|l|}
\cline { 2 - 8 } \multicolumn{1}{c|}{} & \multicolumn{7}{c|}{ Frações de recombinação } \\
\hline Microssatélites & $\mathbf{0 , 0 0}$ & $\mathbf{0 , 0 1}$ & $\mathbf{0 , 0 5}$ & $\mathbf{0 , 1}$ & $\mathbf{0 , 2}$ & $\mathbf{0 , 3}$ & $\mathbf{0 , 4}$ \\
\hline D10S1686 & -1.74 & -1.58 & -1.10 & -0.73 & -0.33 & -0.13 & -0.031 \\
\hline D10S185 & -1.74 & -1.58 & -1.10 & -0.73 & -0.33 & -0.13 & -0.031 \\
\hline D10S192 & -4.69 & -1.40 & -0.72 & -0.44 & -0.19 & -0.07 & -0.01 \\
\hline D10S597 & -0.00 & -0.00 & -0.02 & -0.04 & -0.05 & -0.04 & -0.01 \\
\hline
\end{tabular}

Tabela 18: Lod scores de dois pontos calculados com o programa MLINK do pacote FASTLINK em relação aos microssatélites da região cromossômica 17p13.3-17p13.

\begin{tabular}{|l|l|l|l|l|l|l|l|}
\cline { 2 - 8 } \multicolumn{1}{c|}{} & \multicolumn{7}{c|}{ Frações de recombinação } \\
\hline Microssatélites & $\mathbf{0 , 0 0}$ & $\mathbf{0 , 0 1}$ & $\mathbf{0 , 0 5}$ & $\mathbf{0 , 1}$ & $\mathbf{0 , 2}$ & $\mathbf{0 , 3}$ & $\mathbf{0 , 4}$ \\
\hline D17S849 & 0.55 & 0.54 & 0.49 & 0.42 & 0.28 & 0.15 & 0.04 \\
\hline D17S831 & 0.55 & 0.46 & 0.35 & 0.28 & 0.21 & 0.15 & 0.04 \\
\hline D17S938 & -2.10 & -2.05 & -1.33 & -0.92 & -0.19 & -0.07 & -0.01 \\
\hline D17S1852 & -2.04 & -1.31 & -0.70 & -0.43 & -0.19 & -0.07 & -0.01 \\
\hline
\end{tabular}

Tabela 19: Lod scores de dois pontos calculados com o programa MLINK do pacote FASTLINK em relação aos microssatélites da região cromossômica 7q21.

\begin{tabular}{|l|l|l|l|l|l|l|l|}
\cline { 2 - 8 } \multicolumn{1}{c|}{} & \multicolumn{7}{c|}{ Frações de recombinação } \\
\hline Microssatélites & $\mathbf{0 . 0 0}$ & $\mathbf{0 . 0 1}$ & $\mathbf{0 . 0 5}$ & $\mathbf{0 . 1}$ & $\mathbf{0 . 2}$ & $\mathbf{0 . 3}$ & $\mathbf{0 . 4}$ \\
\hline D7S657 & -0.38 & -0.22 & -0.19 & -0.92 & -0.33 & -0.22 & -0.14 \\
\hline D7S515 & -0.44 & -0.37 & -0.21 & -0.10 & -0.01 & 0.003 & 0.002 \\
\hline D7S486 & 0.55 & 0.54 & 0.49 & 0.42 & 0.28 & 0.15 & 0.04 \\
\hline
\end{tabular}

Tabela 20: Lod scores de dois pontos calculados com o programa MLINK do pacote FASTLINK em relação aos microssatélites da região cromossômica 3q27.

\begin{tabular}{|l|l|l|l|l|l|l|l|}
\cline { 2 - 8 } \multicolumn{1}{c|}{} & \multicolumn{7}{c|}{ Frações de recombinação } \\
\hline Microssatélites & $\mathbf{0 , 0 0}$ & $\mathbf{0 , 0 1}$ & $\mathbf{0 , 0 5}$ & $\mathbf{0 , 1}$ & $\mathbf{0 , 2}$ & $\mathbf{0 , 3}$ & $\mathbf{0 , 4}$ \\
\hline D3S1565 & -.0 .44 & -0.37 & -0.21 & -0.10 & -0.01 & -0.003 & -0.002 \\
\hline D3S1262 & -0.55 & -0.42 & -.0 .35 & -0.23 & -0.10 & -0.01 & -0.005 \\
\hline D3S1580 & -.0 .44 & -0.37 & -0.21 & -0.10 & -0.01 & -0.003 & -0.002 \\
\hline D3S1601 & 0.86 & 0.84 & 0.77 & 0.68 & 0.48 & 0.27 & 0.08 \\
\hline
\end{tabular}


Tabela 21: Lod scores de dois pontos calculados com o programa MLINK do pacote FASTLINK em relação aos microssatélites da região cromossômica 2q31.

\begin{tabular}{|l|l|l|l|l|l|l|l|}
\cline { 2 - 8 } \multicolumn{1}{c|}{} & \multicolumn{7}{c|}{ Frações de recombinação } \\
\hline Microssatélites & $\mathbf{0 , 0 0}$ & $\mathbf{0 , 0 1}$ & $\mathbf{0 , 0 5}$ & $\mathbf{0 , 1}$ & $\mathbf{0 , 2}$ & $\mathbf{0 , 3}$ & $\mathbf{0 , 4}$ \\
\hline D2S151 & 0.33 & 0.27 & 0.25 & 0.19 & 0.11 & 0.05 & 0.01 \\
\hline D2S142 & 0.58 & 0.56 & 0.51 & 0.44 & 0.30 & 0.16 & 0.04 \\
\hline D2S335 & 0.45 & 0.40 & 0.37 & 0.31 & 0.29 & 0.12 & 0.04 \\
\hline D2S364 & 0.25 & 0.25 & 0.22 & 0.18 & 0.11 & 0.05 & 0.01 \\
\hline D2S117 & -1.74 & -1.58 & -1.10 & -0.73 & -0.33 & -0.13 & -0.03 \\
\hline
\end{tabular}

Parametric Analysis for Dominant_Model

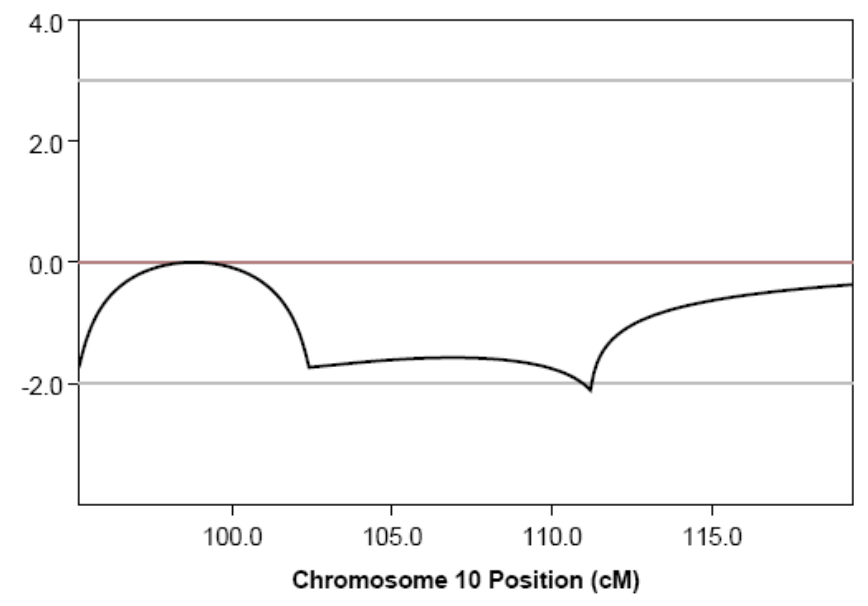

Figura 44. Resultados de lod scores de múltiplos pontos obtidos com os marcadores da região 10q24.

Parametric Analysis for Dominant_Model

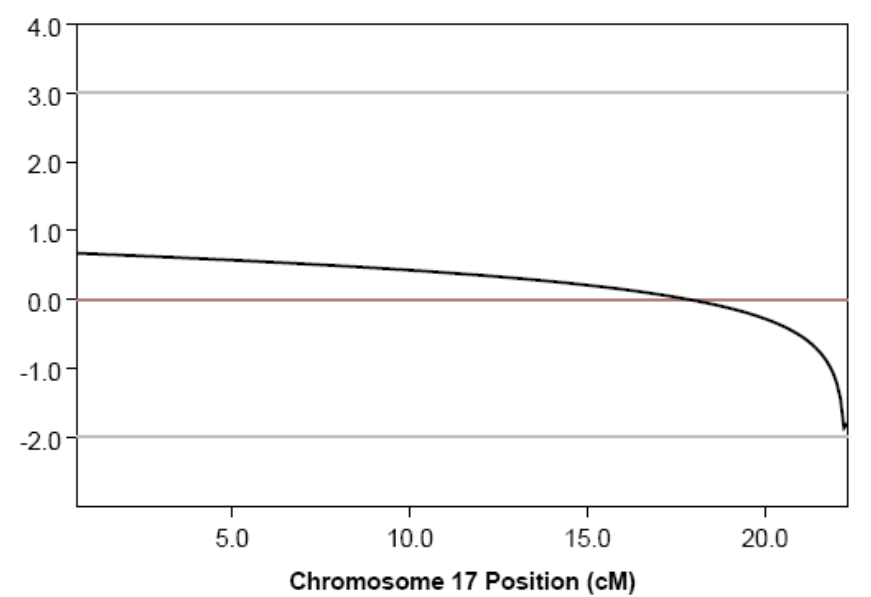

Figura 45. Resultados de lod scores de múltiplos pontos obtidos com os marcadores da região $17 \mathrm{p} 13.3-17 \mathrm{p} 13$. 
Parametric Analysis for Dominant_Model

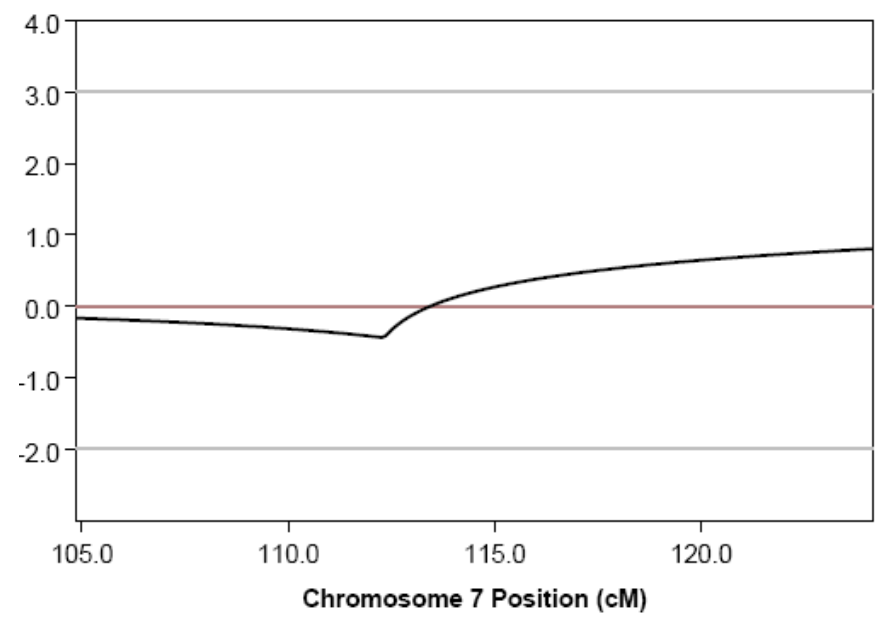

Figura 46. Resultados de lod scores de múltiplos pontos obtidos com os marcadores da região $7 q 21$.

Parametric Analysis for Dominant_Model

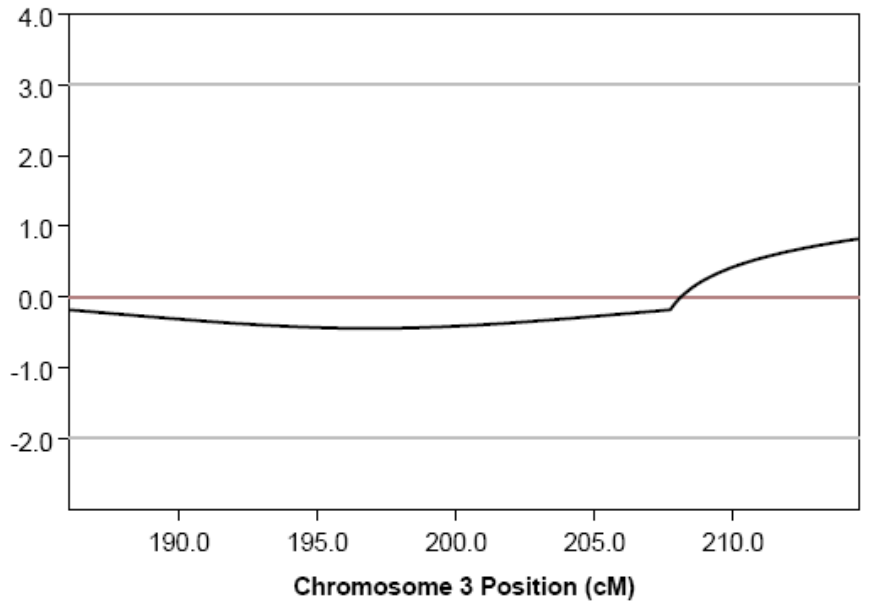

Figura 47. Resultados de lod scores de múltiplos pontos obtidos com os marcadores da região $3 q 27$.

Parametric Analysis for Dominant_Model

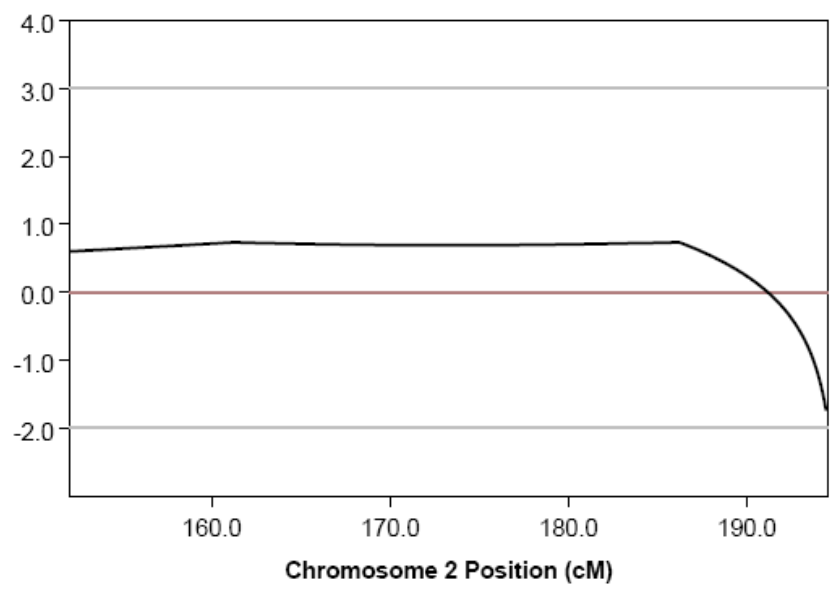

Figura 48. Resultados de lod scores de múltiplos pontos obtidos com os marcadores da região $2 q 31$. 
A análise dos microssatélites próximo ao locos SHFM3 (região cromossômica 10q24) não mostrou evidência de ligação, considerando-se a segregação dos haplótipos e os valores negativos dos lod scores obtidos nas análises paramétricas. Utilizando o padrão de herança dominante com penetrância de aproximadamente $95 \%$ os resultados não revelaram lod scores significativos. Desse modo, a região 10q24 é improvável como candidata a conter o gene responsável pela doença em questão.

Já em relação às análises dos microssatélites próximo à região 17 p13.3-17p13, próximo ao locos SHFM1 (região cromossômica 7q21), próximo ao locos SHFM4 (região cromossômica 3q27) e próximo ao locos SHFM5 (região cromossômica 2q31) não foi possível a exclusão de ligação nessas regiões. Nesses casos, mesmo não se obtendo lod scores positivos acima de 3,00 indicativos de ligação, os lod scores chegaram a mostrar valores positivos e sugestivos em algumas regiões desses cromossomos, tanto para o cálculo de múltiplos pontos como para o cálculo de lod score de dois pontos.

O lod score máximo possível de dois pontos dessa família foi calculado por meio de uma simulação para o padrão de herança autossômico dominante (penetrância 95\%). O valor obtido foi de 1.26. Esse valor de lod score máximo obtido é um valor muito próximo dos valores de lod scores obtidos (cálculo de múltiplos pontos e cálculo de dois pontos) com os marcadores utilizados no cromossomo 17 , no cromossomo 7 , no cromossomo 3 e no cromossomo 2, impedindo a exclusão desses cromossomos, que continuam sendo considerados bons candidatos a conter genes relacionados a defeitos de membros.

Foi executada a varredura genômica em busca do gene responsável pela síndrome na família utilizando as lâminas de 50K do Kit da Affymetrix "GeneChip® Human Mapping 100K Array". Para a varredura foram utilizadas amostras dos três 
indivíduos afetados e dos dois normais, filhos da propósita. Após exame preliminar dos resultados obtidos com as lâminas de array, descartaram-se as possíveis variações de número de cópias nesses indivíduos. As variações dos números de cópias também foram excluídas por meio do uso de lâminas de array CGH (array CGH 108 KIllumina/Agilent), estudo realizado pela pós-doutoranda Erika Freitas no laboratório da Dra. Carla Rosenberg. Realizou-se o cálculo de lod score de múltiplos pontos para todos os SNPs estudados na família com o auxilio do programa Merlin (Figura 49).

Parametric Analysis for Dominant_Model

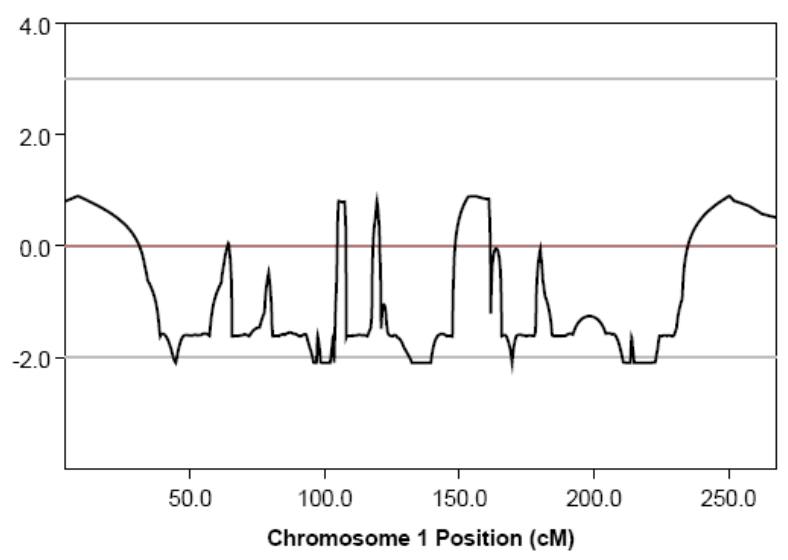

Parametric Analysis for Dominant_Model

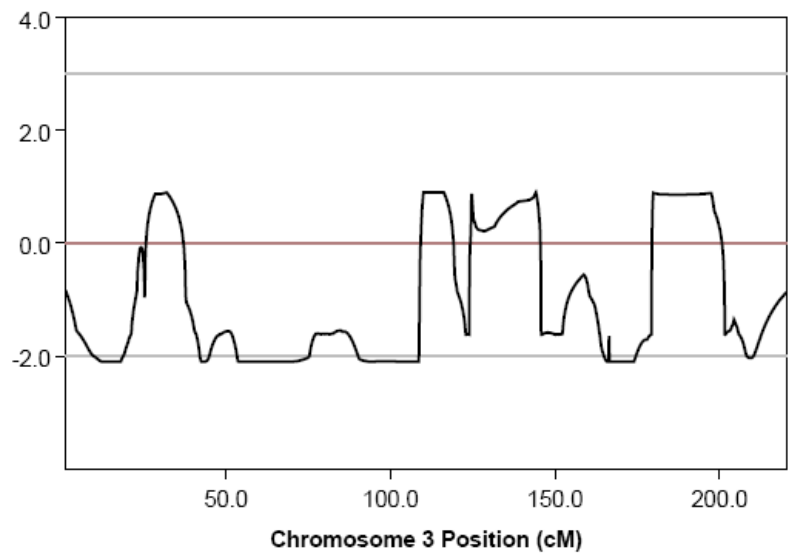

Parametric Analysis for Dominant_Model

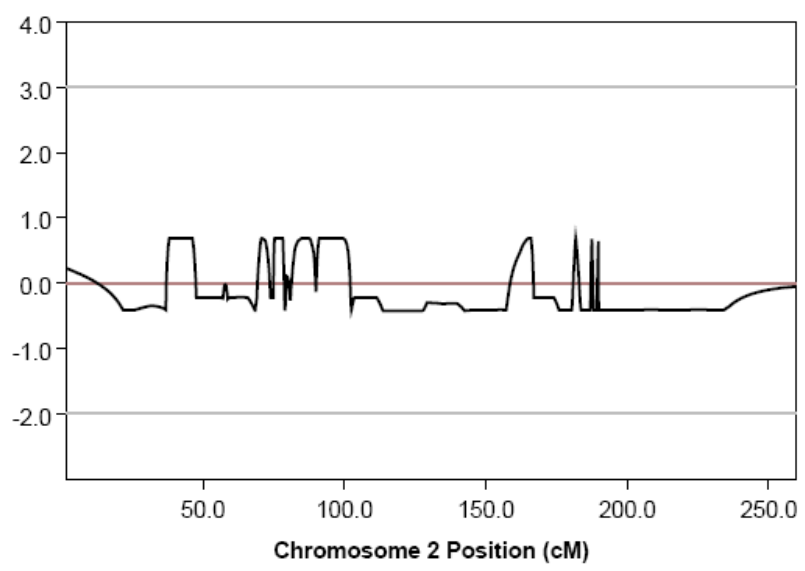

Parametric Analysis for Dominant_Model

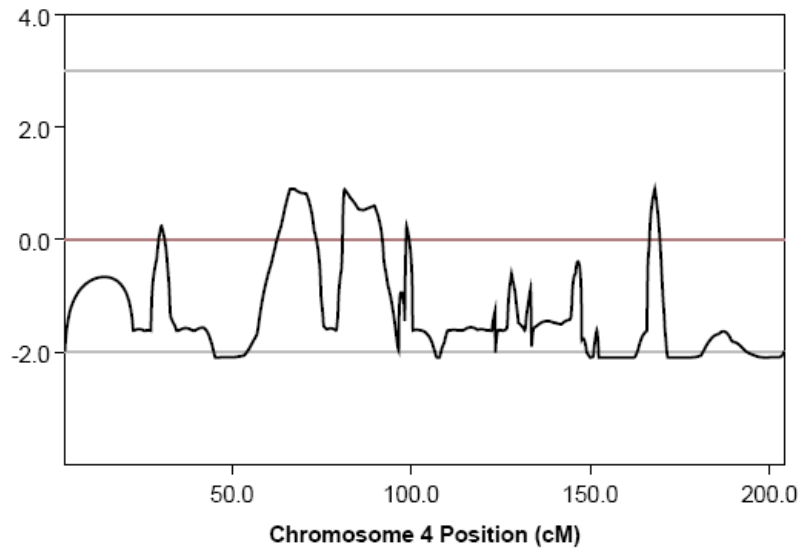

Figura 49. Resultados dos lods scores de múltiplos pontos dos marcadores de cada autossomo calculados pelo programa Merlin. As linhas horizontais de coloração cinza claro em cada gráfico indicam os valores que se convencionaram para excluir ligação $(-2,00)$ e aceitar ligação $(+3,00)$. 
Parametric Analysis for Dominant_Model

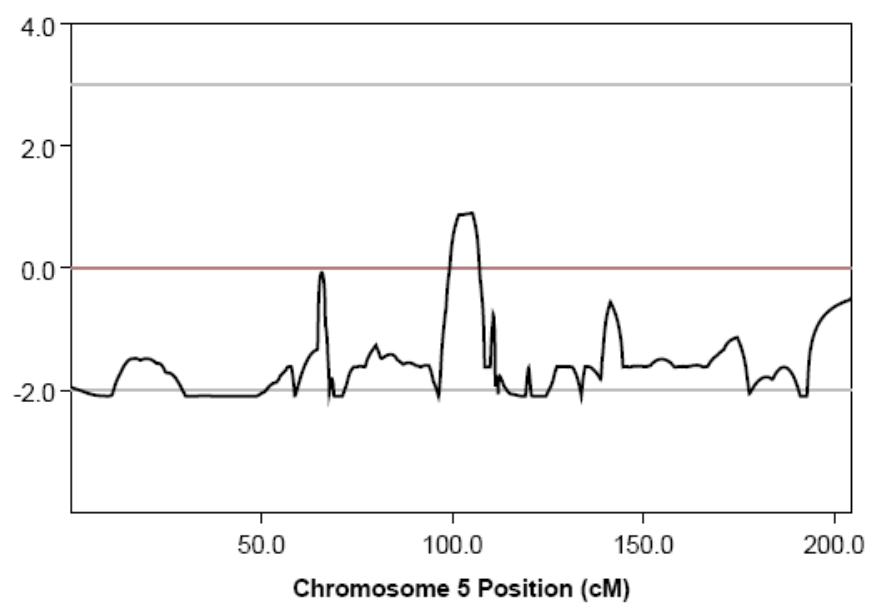

Parametric Analysis for Dominant_Model

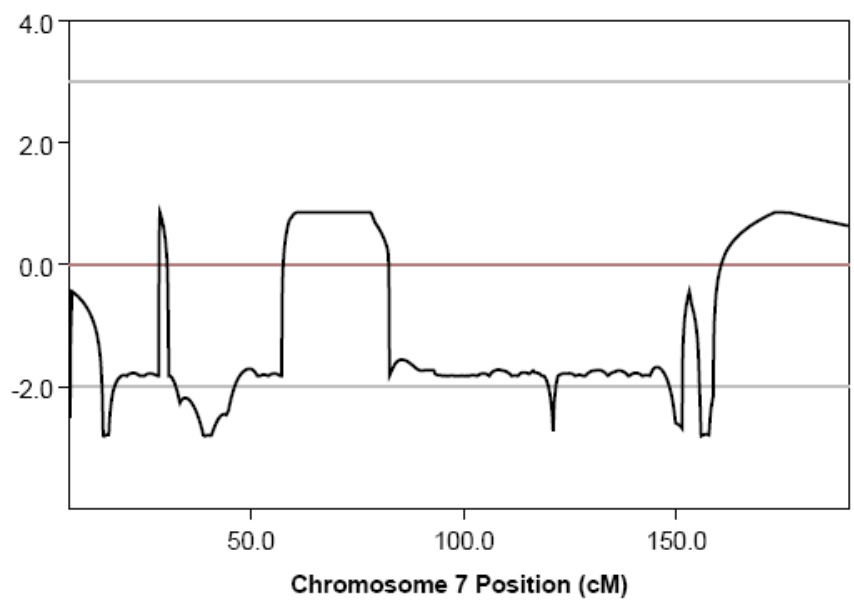

Parametric Analysis for Dominant_Model

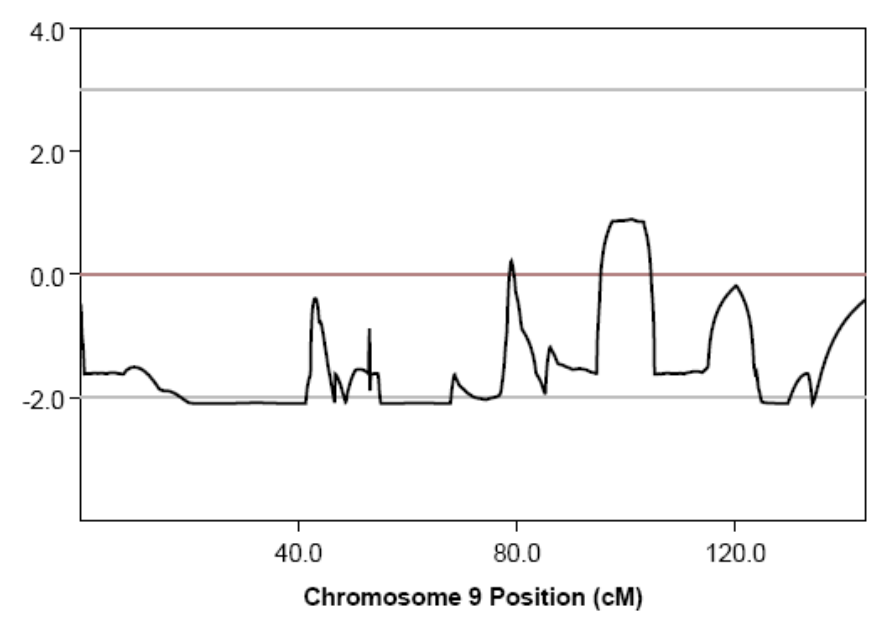

Parametric Analysis for Dominant_Model

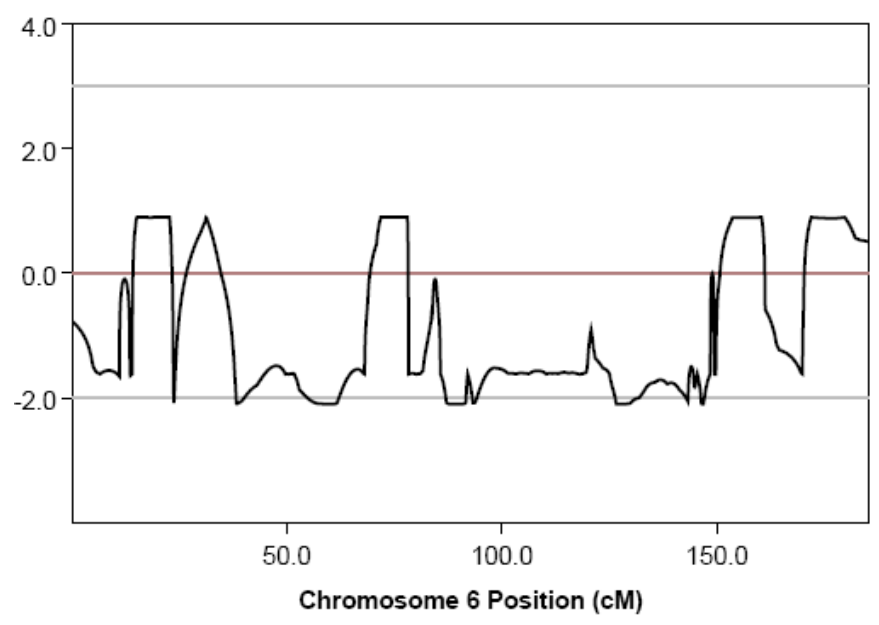

Parametric Analysis for Dominant_Model

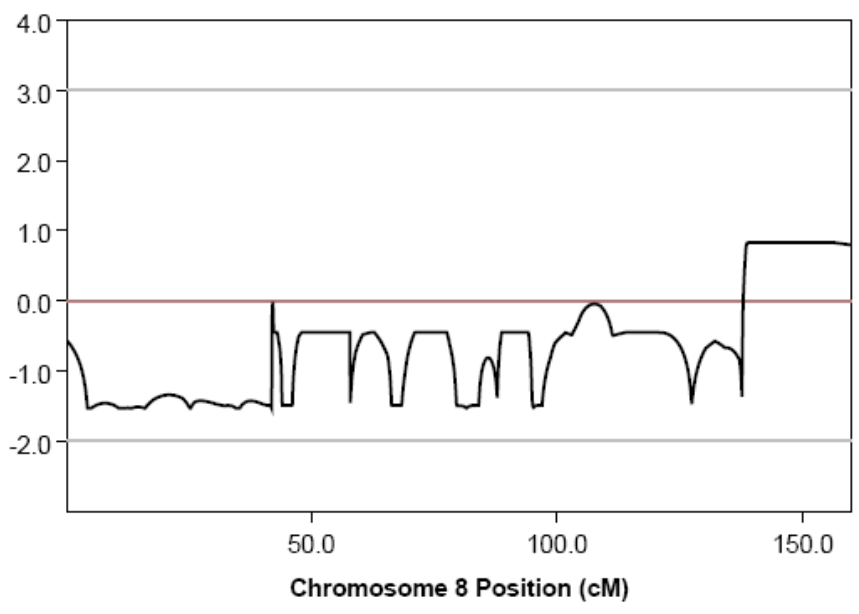

Parametric Analysis for Dominant_Model

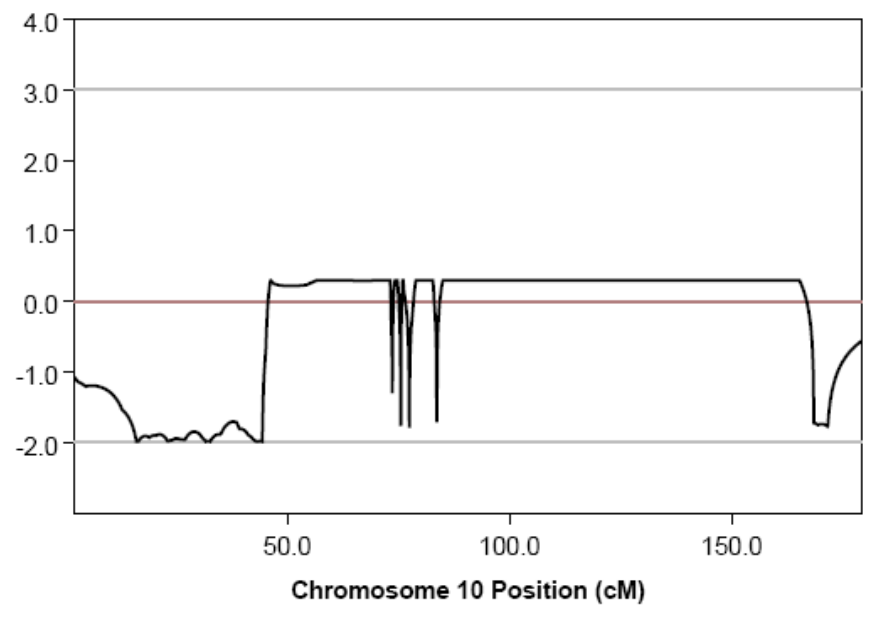

Figura 49 (continuação). Resultados dos lods scores de múltiplos pontos. 
Parametric Analysis for Dominant_Model

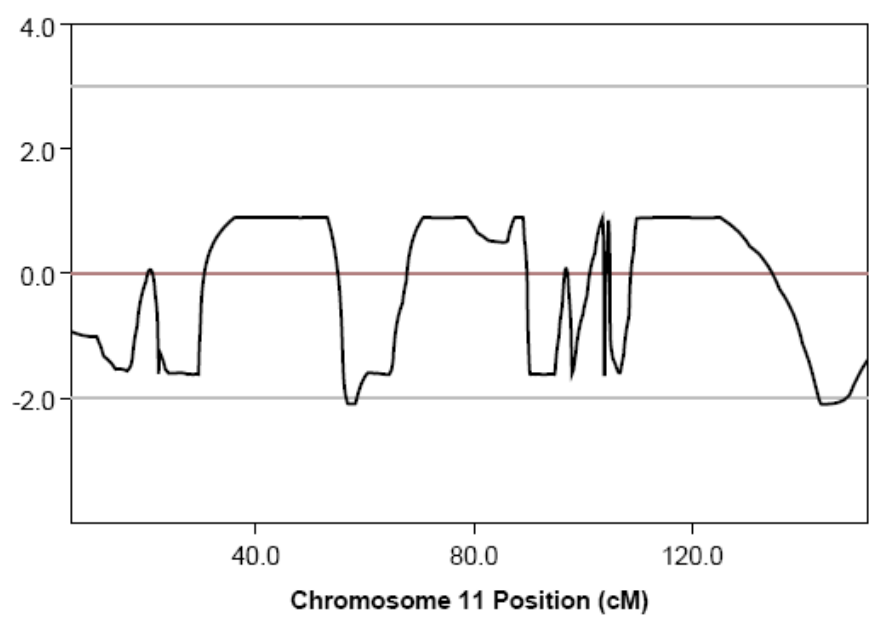

Parametric Analysis for Dominant_Model

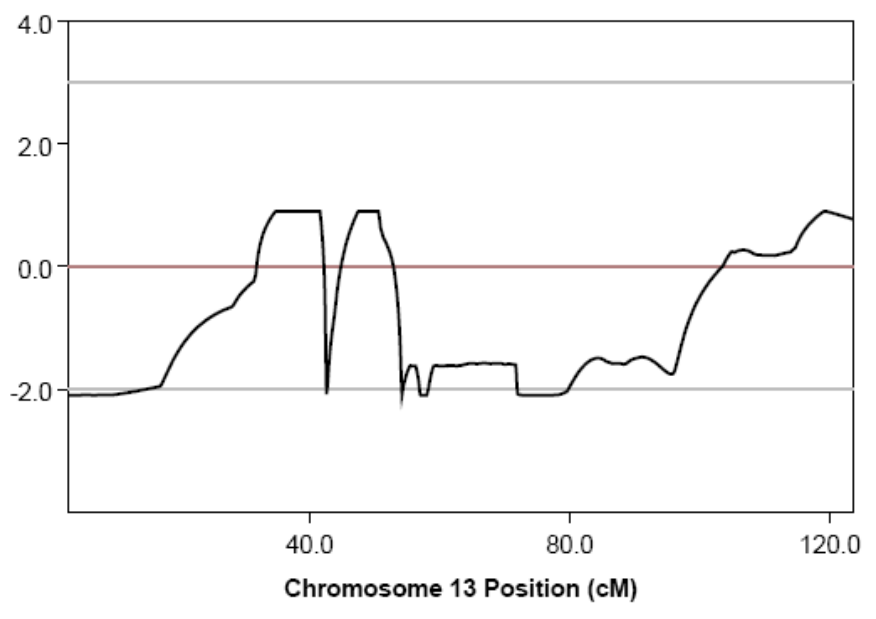

Parametric Analysis for Dominant_Model

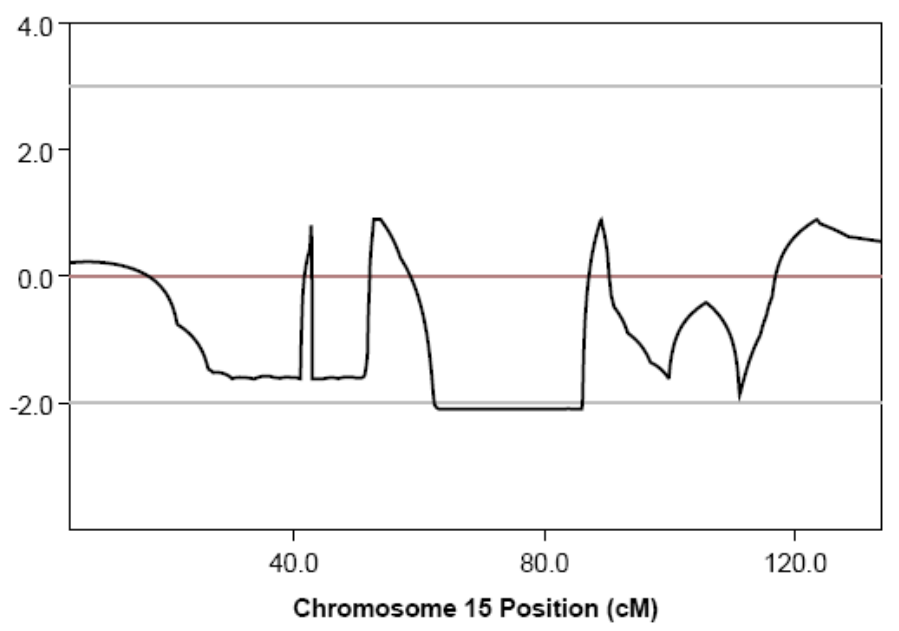

Parametric Analysis for Dominant_Model

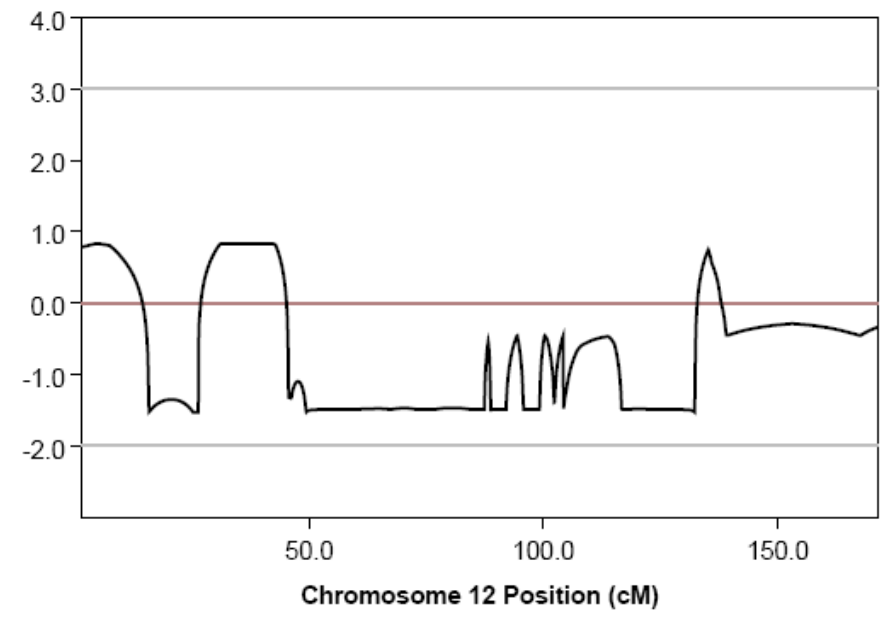

Parametric Analysis for Dominant_Model

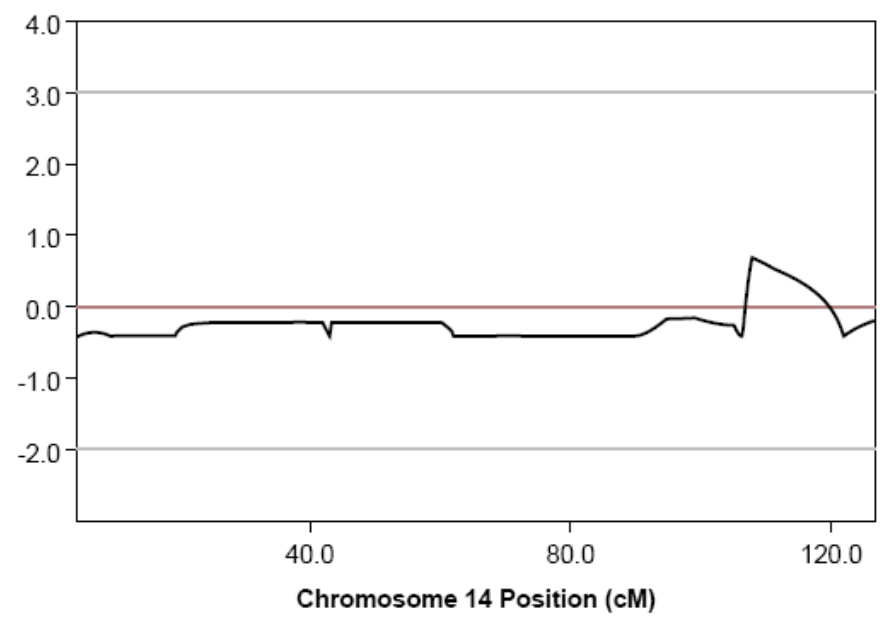

Parametric Analysis for Dominant_Model

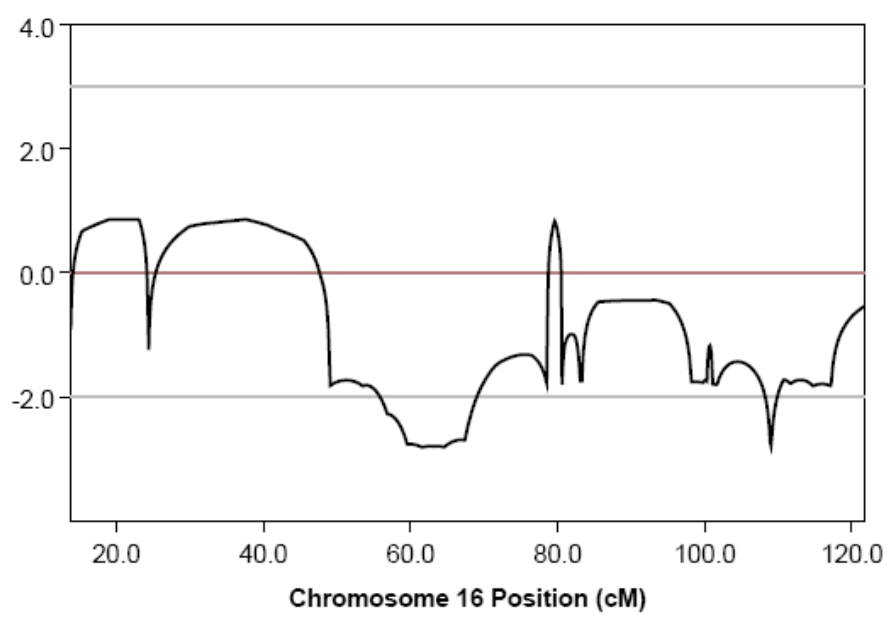

Figura 49 (continuação). Resultados dos lods scores de múltiplos pontos. 
Parametric Analysis for Dominant_Model

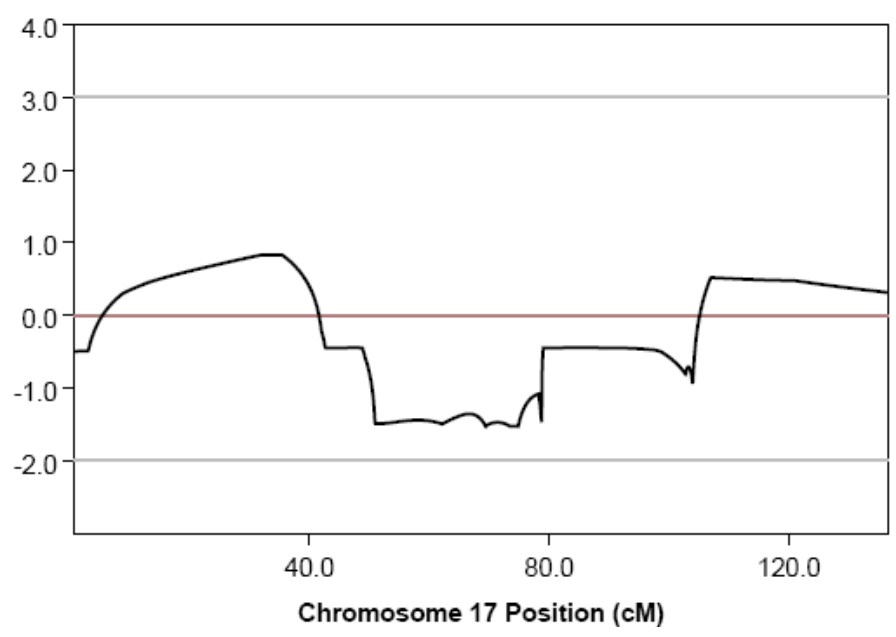

Parametric Analysis for Dominant_Model

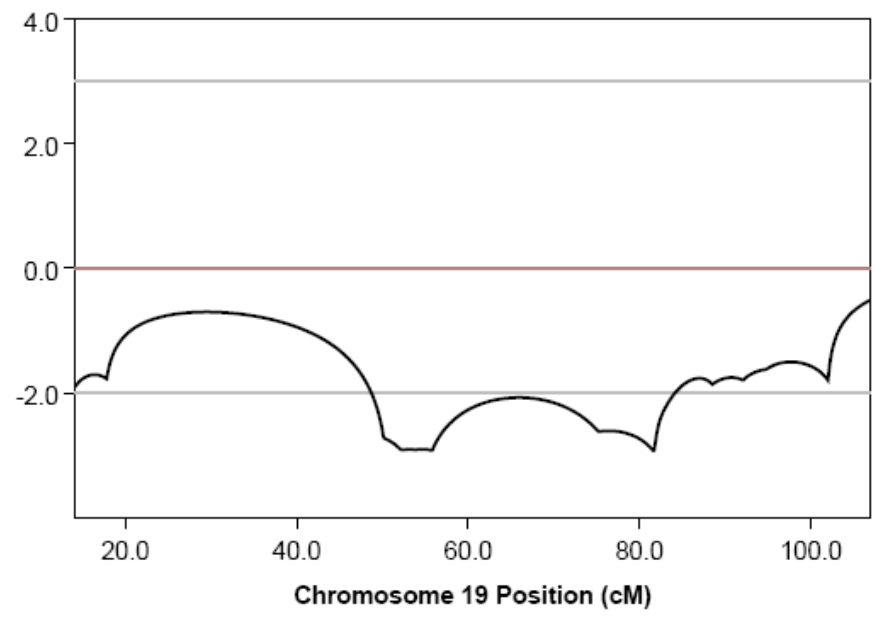

Parametric Analysis for Dominant_Model

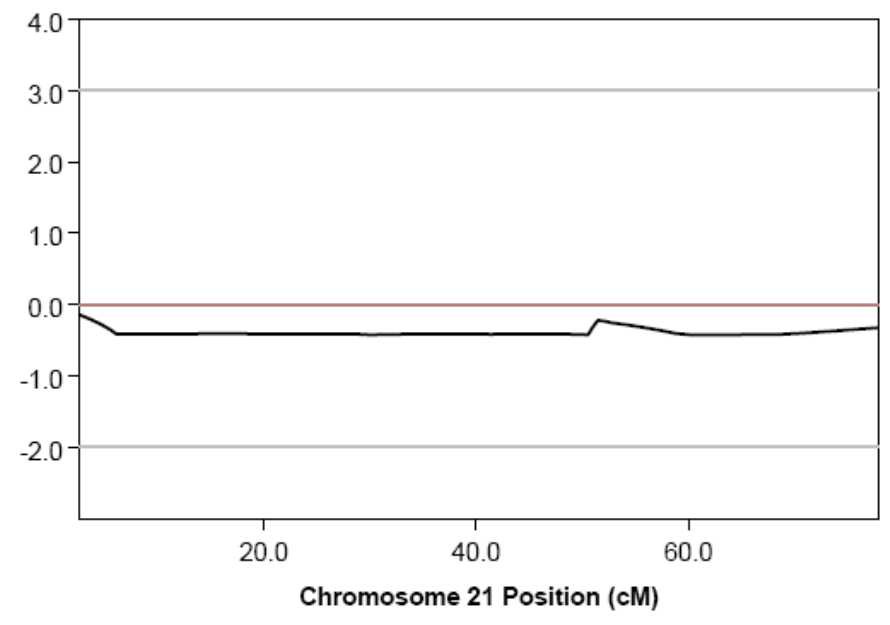

Parametric Analysis for Dominant_Model

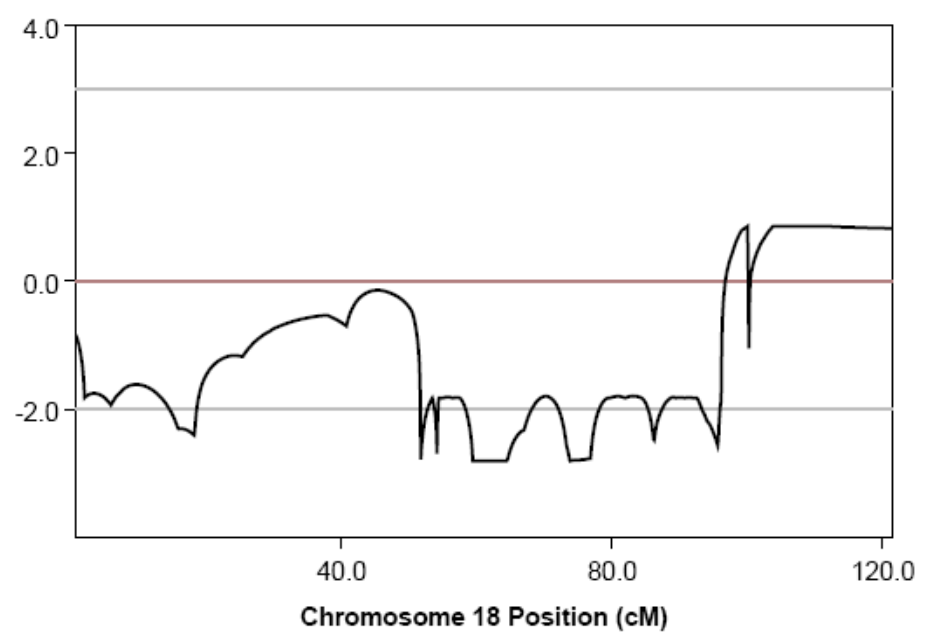

Parametric Analysis for Dominant_Model

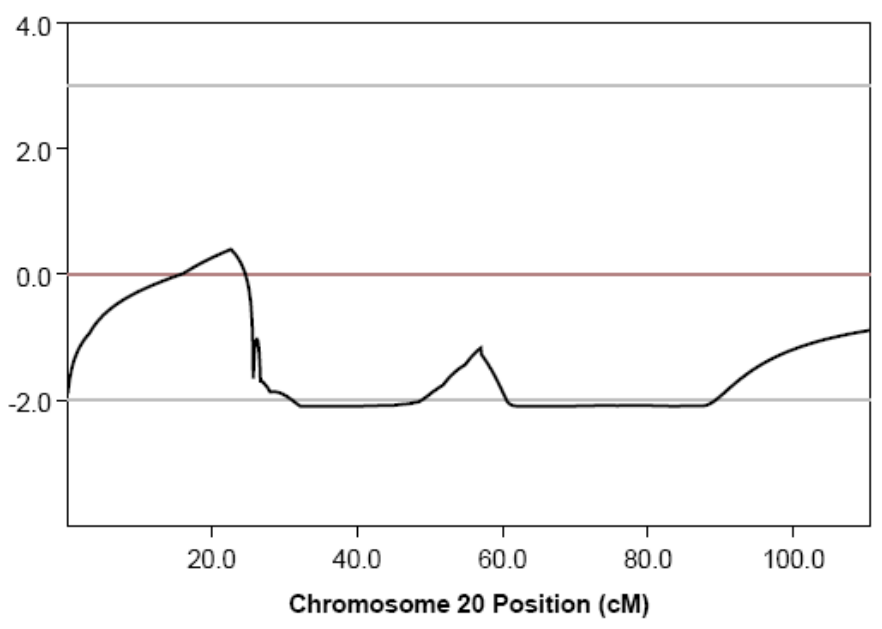

Parametric Analysis for Dominant_Model

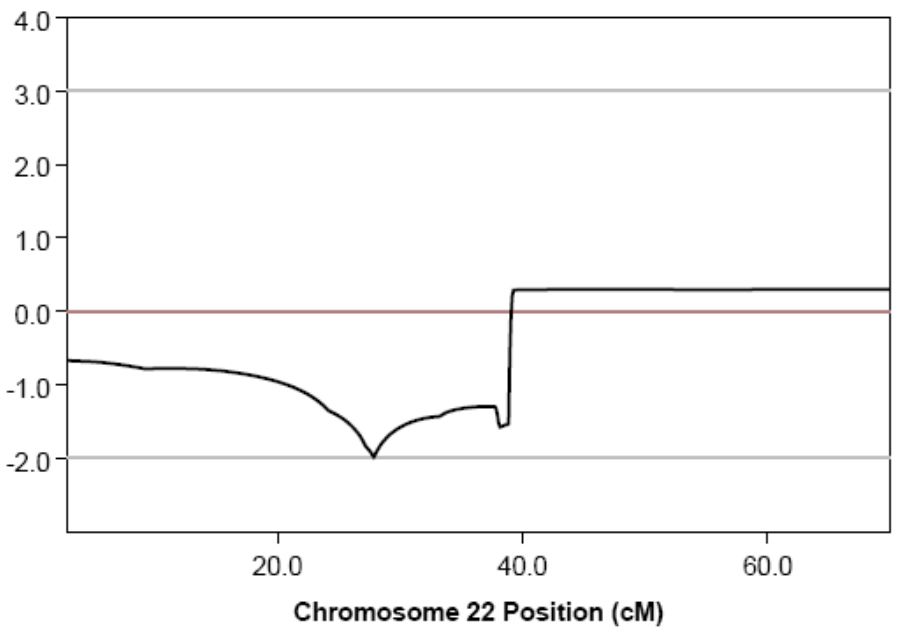

Figura 49 (continuação). Resultados dos lods scores de múltiplos pontos. 
A análise dos SNPs dos cromossomos 10, 19,20, 21 e 22 mostrada na Figura 47, permitiu concluir que é improvável a ligação com esses cromossomos. Já em relação aos demais cromossomos, não se pode excluir completamente a ligação, já que eles em muitas regiões apresentaram lod scores positivos muito próximos do lod máximo calculado para a família. Isso certamente não significa que a família apresenta ligação positiva para todos esses cromossomos. A dificuldade decorre do fato da família ser pequena, pois há somente duas gerações com indivíduos afetados. Mãe e filhos compartilham grande porcentagem dos seus genes, o que torna provável e esperado encontrar lod scores altos em vários cromossomos. Os cromossomos 2, 3 e 7 que tiveram lod scores sugestivos de ligação tanto nos microssatélites quanto nos SNPs apresentam regiões candidatas interessantes, apesar de não compartilharem nenhuma região do cromossomo em comum quando se compara o resultado apontado pelos SNPS e pelos microssatélites. As regiões que os microssatélites indicam como candidatas são diferentes e não coincidem com as regiões indicadas pelos SNPs. Com base nessa conclusão seria necessário utilizar microssatélites nas regiões que apresentaram lod scores próximos ao lod máximo a fim de eliminar ou confirmar essas possíveis ligações em vários dos cromossomos estudados, principalmente nos cromossomos 2,3 e 7 . A região mais interessante para prosseguir os estudos seria a do cromossomo 17, pois houve sugestão também na análise dos microssatélites. Essa região foi mapeada na família 1 que apresentava a síndrome da hemimelia tibial associada à ectrodactlia. Foi possível a identificação precisa da mutação e do gene que levam a síndrome na família 1. Foi realizado o sequenciamento dos oito exons do gene $Y W H A E$, encontrado alterado na família 1 e nenhuma mutação foi encontrada. Talvez outros genes do cromossomo 17 seriam futuros candidatos a sequenciamento. 
Para completar o estudo nessa família sequenciaram-se alguns genes que já foram descritos e estão relacionados a malformações e outros defeitos de membros a fim de identificar possíveis mutações. Os genes sequenciados foram: $S H H$ (7q36), ZRS (7q36.3), WNT7a (3p25), WNT1Ob (12q13.11-q13) e GREM 1 (15q13.3). Todos os exons foram sequenciados e não foi encontrada nenhuma mutação dentro desses cinco genes. 


\section{Conclusão}

Estudamos três famílias com indivíduos afetados por diferentes malformações de membros com o objetivo de mapear novos locos e identificar novas mutações relacionadas a defeitos de membros em famílias brasileiras. Apresentamos as principais conclusões em cada família.

\subsection{Família 1}

A família 1 apresenta nove indivíduos afetados pela síndrome da hemimelia tibial associada à ectrodactilia de herança autossômica dominante (e penetrância reduzida) e seis portadores certos do gene mutado.

A estratégia inicial foi o sequenciamento dos exons de genes localizados na região cromossômica candidata 17p13.1-p13.3. Foram sequenciados todos os exons de seis genes contidos na região (RPA1, YWHAE, CRK, SERPINF1, RTN4RL1 e TUSC5) e nenhuma mutação patogênica foi encontrada. Participamos de uma pesquisa em colaboração com o grupo do Dr. Mundlos (Berlin-Alemanha) que possuía mais três famílias com o mesmo fenótipo e com ligação com a mesma região do cromossomo 17. Esse grupo detectou duplicações nessa região cromossômica. A fim de procurar mutações semelhantes às encontradas pelo grupo alemão, executou-se o PCR quantitativo com alguns primers da região 17p13.3. Desse modo, foi possível identificar uma duplicação de $114 \mathrm{~Kb}$ em todos os indivíduos afetados e portadores certos da doença em questão. A duplicação encontra-se em tandem, inserida diretamente e na mesma orientação da sequência original. Essa duplicação interrompe o intron 4-5 do gene $Y W H A E$ que, portanto, está parcialmente duplicado. O gene $Y W H A E$ é responsável pela codificação de uma proteína que interage e regula negativamente a expressão do 
gene $S H H$, previamente associado a malformações de membros e pode estar relacionado ao fenótipo da doença em questão. A duplicação também inclui outros dois genes: BHLHA9 e TUSC5. O gene BHLHA9 e o gene TUSC5 estão presentes em três cópias. O gene TUSC5 já for associado a microdeleções e microduplicações envolvendo outros genes do cromossomo 17, como o $Y W H A E$ e o $C R K$, mas nunca foi associado a fenótipos de malformações de membros. Já o BHLHA9 é o melhor gene candidato como possível responsável pelos defeitos de membros, já que é expresso durante a formação dos membros na crista ectodérmica apical (AER).

\subsection{Família 2}

A família 2 é constituída de seis indivíduos afetados por uma síndrome aparentemente nova caracterizada por: aplasia/hipoplasia fibular, ectrodactilia, anoníquia/hipoplasia ungueal, entre outros defeitos.

Nessa família realizaram-se estudos preliminares de ligação com microssatélites que permitiriam excluir a ligação com algumas regiões cromossômicas já conhecidas associadas a malformações de membros. O estudo de mapeamento teve inicio com marcadores próximos a locos já mapeados de ectrodactilia, hemimelia tibial, agenesia de fíbula e outros defeitos de membros e, como essas regiões foram excluídas, a varredura genômica foi executada.

O cálculo de lod score de múltiplos pontos mostrou alguns resultados sugestivos de ligação com as regiões cromossômicas 5p15.33, 6p25.3, 10p15.3 e 11p15.5 e 13q12.11. Utilizando microssatélites mapeados nessas regiões realizaram-se estudos de ligação com microssatélites que permitiriam excluir ou confirmar a ligação. Por fim, apenas as regiões $5 \mathrm{p} 15.33$ e $11 \mathrm{p} 15.5$ mostraram lods scores positivos e com valores próximos ao lod score máximo calculado para essa família, indicando possível ligação. 
Por fim, sequenciaram-se também alguns genes que já foram descritos e estão relacionados a malformações de membros a fim de identificar possíveis mutações $(\mathrm{SHH}$, ZRS, WNT7a, WNT10b e GREM1). Todos os exons foram sequenciados e não foi encontrada nenhuma mutação. Refinamentos dos estudos de ligação nos cromossomos 5 e 11 seriam indicados para prosseguir com o estudo da família.

\subsection{Família 3}

A família é composta por três indivíduos afetados por um quadro variável de defeitos de membros entre eles polissindactilia, sindactilia, camptodactilia e defeitos ungueais.

Nessa família também realizaram-se estudos preliminares de ligação com microssatélites que permitiriam excluir a ligação com algumas regiões cromossômicas já conhecidas associadas a malformações de membros. O estudo de mapeamento teve inicio com marcadores próximos a locos já mapeados de ectrodactilia, hemimelia tibial, agenesia de fíbula e outros defeitos de membros e como essas regiões foram excluídas, a varredura genômica foi executada.

O cálculo de lod score de múltiplos pontos atingiu valores positivos nos estudos de ligação com os cromossomos 1, 2, 3, 4, 5, 6, 7, 8, 9, 11, 12, 13, 14, 15, 16, 17 e 18. Nesses casos, não se pode excluir completamente a ligação, já que os lod scores positivos se mostraram muito próximos ao lod máximo calculado para a família. Como a família é pequena, há somente duas gerações com indivíduos afetados, é esperado que mãe e filhos compartilharem várias regiões cromossômicas e que se encontre lod scores alto em vários cromossomos. Com base nessa conclusão, seria necessário utilizar microssatélites nas regiões que apresentaram lod scores próximos ao lod máximo a fim 
de eliminar ou confirmar essas possíveis ligações em vários dos cromossomos estudados.

Foi realizado nessa família também o sequenciamento dos oito exons do gene YWHAE, encontrado alterado na família 1 e considerado como uma possível causa do fenótipo. Entretanto, nenhuma mutação foi encontrada. Por fim, também sequenciaramse os genes que já foram descritos e estão relacionados a malformações de membros a fim de identificar possíveis mutações (SHH, ZRS, WNT7a, WNT1Ob e GREM 1). Todos os exons foram sequenciados e não foi encontrada nenhuma mutação. 


\section{Referências Bibliográficas}

Abecasis GR, Cherny SS, Cookson WO, Cardon LR (2002). Merlin-rapid analysis of dense genetic maps using sparse gene flow trees. Nat Genet 30:97-101.

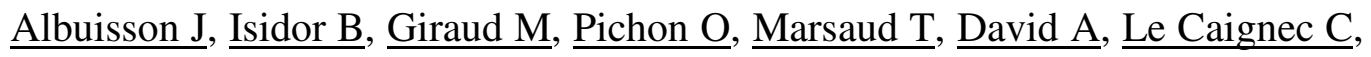
Bezieau S (2010). Identification of two novel mutations in Shh long-range regulator associated with familial pre-axial polydactyly. Clinical Genetics in press.

Adamska M, Billi AC, Cheek S, Meisler MH (2010). Genetic Interaction Between Wnt7a and Lrp6 During Patterning of Dorsal and Posterior Structures of the Mouse Limb. Developmental Biology 342 (2010) 169-179.

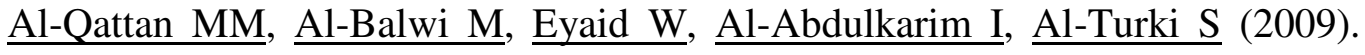
Congenital duplication of the palm syndrome: gene analysis and the molecular basis of its clinical features. J Hand Surg Eur Vol. 34(2):247-51.

$\underline{\text { Blattner A }}, \underline{\text { Huber AR}}, \underline{\text { Röthlisberger B }}$ (2010). Homozygous nonsense mutation in WNT10B and sporadic split-hand/foot malformation (SHFM) with autosomal recessive inheritance. Am J Med Genet A. 152A(8):2053-6.

Bénazet JD, Bischofberger M, Tiecke, Gonçalves A, Martin JF, Zuniga A, Naef F, Zeller R (2009). A Self-Regulatory System of Interlinked Signaling Feedback Loops Controls Mouse Limb Patterning. Science. 323.

Borozdin, W., Bravo-Ferrer Acosta, A. M., Seemanova, E., Leipoldt, M., Bamshad, M. J., Unger, S., Kohlhase, J (2006). Contiguous hemizygous deletion of TBX5, TBX3, and RBM19 resulting in a combined phenotype of Holt-Oram and ulnarmammary syndromes. Am. J. Med. Genet. 140A: 1880-1886.

$\underline{\text { Bouldin CM}}, \underline{\text { Gritli-Linde A, }}$ Ahn S, Harfe BD (2010) Shh pathway activation is present and required within the vertebrate limb bud apical ectodermal ridge for normal autopod patterning. Proc Natl Acad Sci U S A. 107(12):5489-94. 
Bruno DL, Anderlid BM, Lindstrand A, van Ravenswaaij-Arts C, Ganesamoorthy D, Lundin J, Martin CL, Douglas J, Nowak C, Adam MP, Kooy RF,

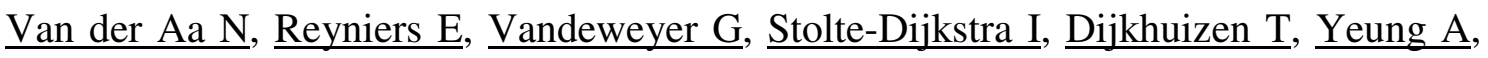

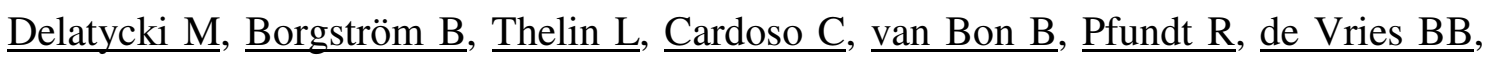

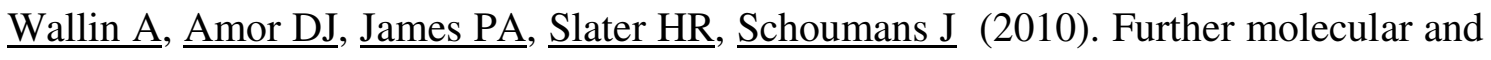
clinical delineation of co-locating 17p13.3 microdeletions and microduplications that show distinctive phenotypes. J Med Genet. 47(5):299-311.

Cottingham RW Jr, Idury RM, Schaffer AA (1993). Faster sequential genetic linkage computations. Am J Hum Genet 53(1): 252-63.

Courtens W, Jespers A, Harrewijn I, Puylaert D, Vanhoenacker F (2005) Fibular aplasia, tibial campomelia, and oligosyndactyly in a male newborn infant: a case report and review of the literature. Am J Med Genet 134(3): 321-5.

Crackower MA, Scherer SW, Rommens JM, Hui CC, Poorkaj P, Soder S, Cobben JM, Hudgins L, Evans JP, Tsui LC. (1996). Fine mapping of the autosomal dominant split hand/split foot locus on chromosome 7, band q21.3-q22.1. Am J Hum Genet 55: 12-20.

de Mollerat XJ, Gurrieri F, Morgan CT, Sangiorgi E, Everman DB, Gaspari P, Amiel J, Bamshad MJ, Lyle R, Blouin JL, Allanson JE, Le Marec B, Wilson M, Braverman NE, Radhakrishna U, Delozier-Blanchet C, Abbott A, Elghouzzi V, Antonarakis S, Stevenson RE, Munnich A, Neri G, Schwartz CE (2003). A genomic rearrangement resulting in a tandem duplication is associated with split hand-split foot malformation 3 (SHFM3) at 10q24.Hum Mol Genet.12(16):1959-71.

Douzgou, S., Lehmann, K., Mingarelli, R., Mundlos, S., Dallapiccola, B (2008). Compound heterozygosity for GDF5 in Du Pan type chondrodysplasia. Am. J. Med. Genet. 146A: 2116-2121,

Duijf PH, Van Bokhoven H, Brunner HG (2003). Pathogenesis of splithand/split-foot malformation. Hum Mol Genet 12(Suppl 1):R51-60. 
Evans DM, Cardon LR (2004). Guidelines for genotyping in genomewide linkage studies: single-nucleotide-polymorphism maps versus microsatellite maps. $\underline{A m}$ Hum Genet. 75(4):687-92.

Everman DB, Morgan CT, Lyle R, Laughridge ME, Bamshad MJ, Clarkson KB, Colby R, Gurrieri F, Innes AM, Roberson J, Schrander-Stumpel C, van Bokhoven H, Antonarakis SE, Schwartz CE (2006). Frequency of genomic rearrangements involving the SHFM3 locus at chromosome 10q24 in syndromic and non-syndromic splithand/foot malformation. Am J Med Genet A. 140(13):1375-83.

Ensembl- URL: http://www.ensembl.org/. Acesso em 03 de Agosto de 2010.

Farooq M, Troelsen JT, Boyd M, Eiberg H, Hansen L, Hussain MS, Rehman S, Azhar A, Ali A, Bakhtiar SM, Tommerup N, Baig SM, Kjaer KW (2010). Preaxial polydactyly/triphalangeal thumb is associated with changed transcription factor-binding affinity in a family with a novel point mutation in the long-range cis-regulatory element ZRS. Eur J Hum Genet. 18(6):733-6.

Fernandez-Palazzi F, Bendahan J, Rivas S (1998). Congenital deficiency of the tibia: a report on 22 cases. J Pediatr Orthop B 7(4):298-302. Review.

Furniss D, Kan SH, Taylor IB, Johnson D, Critchley PS, Giele HP, Wilkie AO (2009). Genetic screening of 202 individuals with congenital limb malformations and requiring reconstructive surgery. Journal of Medical Genetics 46(11):730-5.

$\underline{\text { Galli A, Robay D, Osterwalder M, Bao X }}$, Bénazet JD, Tariq M, Paro R,

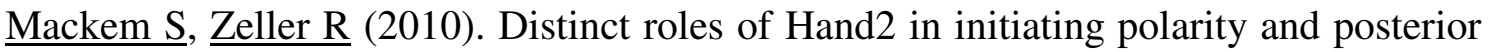
Shh expression during the onset of mouse limb bud development. PLoS Genet. 6(4):e1000901.

GenBank/NCBI - URL: http:// www.ncbi.nih.gov/ Acesso em 03 de Agosto de 2010. 
Geneatlas - URL: http:// www.geneatlas.org .Acesso em 03 de Agosto de 2010.

Genome Browser (UCSC) - URL: http:// www.genome.ucsc.edu/. Acesso em 03 de Agosto de 2010.

Gilbert SF (2003). Developmental Biology. 17ª edição - Editora Sinauer., USA.

$\underline{\text { Gurnett CA, Bowcock AM, Dietz FR, Morcuende JA, Murray JC, Dobbs MB }}$ (2007). Two novel point mutations in the long-range SHH enhancer in three families with triphalangeal thumb and preaxial polydactyly. Am J Med Genet A. 143(1):27-32.

Gurrieri F, Prinos P, Tackels D, Kilpatrick MW, Allanson J, Genuardi M, Vuckov A, Nanni L, Sangiorgi E, Garofalo G, Nunes ME, Neri G, Schwartz C, Tsipouras P. (1996) A split hand-split foot (SHFM3) gene is located at 10q24q25. Am J Med Genet 62:427-436.

HUGO Gene Nomenclature Committee (HGNC-08/2003), Departament of Biology, University College London, Wolfson House, 4 Stephenson Way, London NW1 2HE, UK (URL:http://www.gene.ucl.ac.uk/nomenclature/).

Hill RE, Heaney SJH, Lettice LA (2003). Sonic hedgehog: restricted expression and limb dysmorphologies. Journal of Anatomy 202:13-20.

Ivanov BD, Voet T,Smet LD, Vermeesch JR, Devriendt K, Fryns JP, Debeer P (2010). Genomic rearrangements of the GREM1-FMN1 locus cause oligosyndactyly, radio-ulnar synostosis, hearing loss, renal defects syndrome and CenanieLenz-like nonsyndromic oligosyndactyly. J Med Genet 47: 569-574.

Kano H, Kurosawa K, Horii E, Ikegawa S, Yoshikawa H, Kurahashi H, Toda T. (2005) Genomic rearrangement at 10q24 in non-syndromic split-hand/split-foot malformation. Hum Genet 118(3-4):477-83. 
Kimura, L. (2010) Fatores genéticos associados à hipertensão em populações afro-brasileira. Dissertação apresentada ao Instituto de Biociencias da Universidade de São Paulo para obtenção de Título de Doutor em Ciências na área de Biologia/Genética. São Paulo, SP.

Koide H, Shibata T, Yamada N, Asaki T, Nagao T, Yoshida T, Noguchi Y, Tanaka T, Saito Y, Tatsuno I (2007). Tumor suppressor candidate 5 (TUSC5) is expressed in brown adipocytes. Biochem Biophys Res Commun. Aug 17;360(1):139-45.

Kruglyak L (1997). The use of a genetic map of biallelic markers in linkage studies. Nature Genetics 17:21-24.

Kruglyak L, Lander ES (1995) Complete multipoint sib-pair analysis of qualitative and quantitative traits. Am J Hum Genet 57:439-454

Lathrop GM, Lalouel JM, Julier C, Ott J (1985) Multilocus linkage analysis in humans. Detection of linkage and estimation of recombination. Am J Hum Genet 37: $482-498$

Lettice LA, Heaney SJH, Purdie LA, Li L, Beer P, Oostra BA, Goode D, Elgar G, Hill RE, Graaff E (2003). A long-range Shh enhancer regulates expression in the developing limb and fin and is associated with preaxial polydactyly. Human Molecular Genetics 12(14).

Lewin SO, Opitz JM.(1986) Fibular a/hypoplasia: review and documentation of the fibular developmental field. Am J Med Genet Suppl 2: 215-38. Review.

Lezirovitz K (2007) Mapeamento de genes em doenças geneticamente heterogêneas: Surdez e Hemimelia Tibial associada à Ectrodactilia. Dissertação apresentada ao Instituto de Biociencias da Universidade de São Paulo para obtenção de Título de Doutor em Ciências na área de Biologia/Genética. São Paulo, SP.

Lezirovitz K., Maestrelli S. R.P., Cotrim N.H., Horimoto A.R.V.R., Otto P.A, Pearson P.L., Mingroni-Netto R.C (2008) A novel locus for ectrodactyly associated 
with tibial hemimelia (SHFLD) maps to chromosome region 17p13.1-17p13.3. Am J Hum Genet 123:625-31.

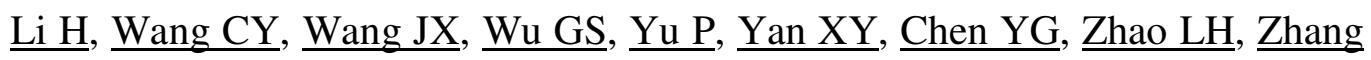
$\underline{\text { YP }}$ (2009). Mutation analysis of a large Chinese pedigree with congenital preaxial polydactyly. Eur J Hum Genet. 17(5):604-10.

Lin JM, Wan L, Tsai YY, Lin HJ, Tsai Y, Lee CC, Tsai CH, Tseng SH, Tsai FJ.(2007) Pigment epithelium-derived factor gene Met72Thr polymorphism is associated with increased risk of wet age-related macular degeneration. America Journal of Ophthalmology 145:716-721.

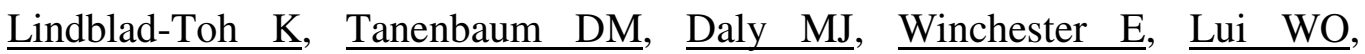
Villapakkam A, Stanton SE, Larsson C, Hudson TJ, Johnson BE, Lander ES, Meyerson M (2000). Loss-of-heterozygosity analysis of small-cell lung carcinomas using singlenucleotide polymorphism arrays. Nat Biotechnol. 18(9):1001-5.

Marshfield comprehensive human genetics maps (2003). World Wide Web URL: http://research.marshfieldclinic.org/genetics. Acesso em 03 de Agosto de 2010.

Masashi I, Takao H, Shinichiro T, Junko Uraguchi-Asaki, Kazuhito T, Anthony Wynshaw-Boris, Hiroshi U, Toshiya I, Keizo T, Tsuyoshi M, Norio O, Kozo K, Nakao I (2008). Identification of YWHAE, a gene encoding 14-3-3epsilon, as a possible susceptibility gene for schizophrenia. Human Molecular Genetics, 17(20).

Matsuyama J, Mabuchi A, Zhang J, lida A, Ikeda T, Kimizuka M, Ikegawa S (2003). A pair of sibs with tibial hemimelia born to phenotypically normal parents. $J$ Hum Genet. 48(4):173-6.

MGI. Mouse Genome Informatics. URL : http://www.informatics.jax.org/. Acesso em 01 de Julho de 2009.

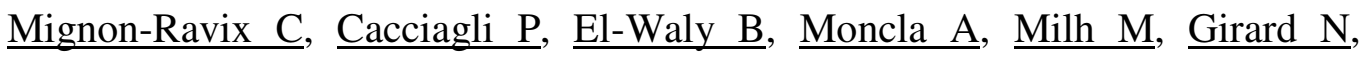
Chabrol B, Philip N, Villard L (2010). Deletion of YWHAE in a patient with 
periventricular heterotopias and pronounced corpus callosum hypoplasia. $\underline{\mathrm{J} \text { Med }}$ Genet.47(2):132-6.

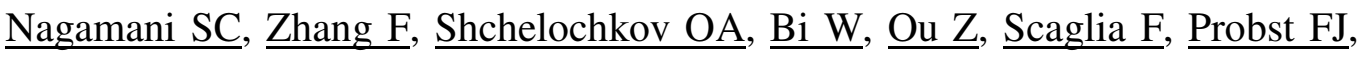

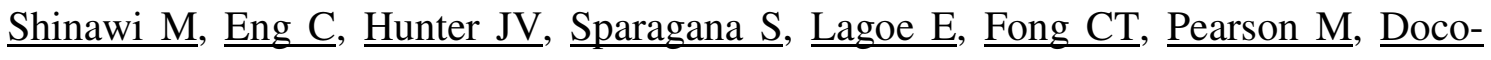
$\underline{\text { Fenzy M}}$, Landais E, Mozelle M, Chinault AC, $\underline{\text { Patel A }}$, Bacino CA, Sahoo T, Kang SH, Cheung SW, Lupski JR, Stankiewicz P (2010). Microdeletions including YWHAE in the Miller-Dieker syndrome region on chromosome $17 \mathrm{p} 13.3$ result in facial dysmorphisms, growth restriction, and cognitive impairment. J Med Genet. 46(12):82533.

Naveed M, Nath SK, Gaines M, Al-Ali MT, Al-Khaja N, Hutchings D, Golla J, Deutsch S, Bottani A, Antonarakis SE, Ratnamala U, Radhakrishna U (2007). Genomewide linkage scan for split-hand/foot malformation with long-bone deficiency in a large Arab family identifies two novel susceptibility loci on chromosomes 1q42.2q43 and 6q14.1. Am J Hum Genet 80(1):105-11.

NCBI-National Center for Biotechnology Information. National Library of Medicine - U.S. Government. World Wide Web URL: http:// www.ncbi,nlm.nih.gov/. Acesso em 03 de Agosto de 2010.

Nelson e Holmes, 1980 apud Nunes ME, Schutt G, Kapur RP, Luthardt F, Kukolich M, Byers P, Evans JP (1995). A second autosomal split hand/split foot locus maps to chromosome 10q24-q25. Hum Mol Genet. 4(11):2165-70.

Niswander L (2003). Pattern Formation: Old Models Out on a Limb. Nat Rev Genet 4(2): 133-143.

Nunes ME, Schutt G, Kapur RP, Luthardt F, Kukolich M, Byers P, Evans JP (1995). A second autosomal split hand/split foot locus maps to chromosome 10q24-q25. Hum Mol Genet. 4(11):2165-70.

OMIM. Online Mendelian Inheritance in Man. URL: http://www.ncbi.nlm.nih.gov/omim. Acesso em 01 de Julho de 2009. 
Oort PJ, Knotts TA, Grino M, Naour N, Bastard JP, Clément K, Ninkina N, Buchman VL, Permana PA, Luo X, Pan G, Dunn TN, Adams SH (2009). Gammasynuclein is an adipocyte-neuron gene coordinately expressed with leptin and increased in human obesity. PPAR Res. Mar 1.PMID: 20204174

Oort PJ, Warden CH, Baumann TK, Knotts TA, Adams SH (2008). Characterization of Tusc5, an adipocyte gene co-expressed in peripheral neurons. $J$ Nutr. May;138(5):841-8.

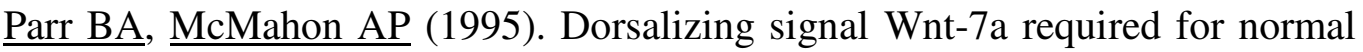
polarity of D-V and A-P axes of mouse limb. Nature 374(6520):350-353.

PosMed $^{\mathrm{TM}}$ - URL: http://omicspace.riken.jp/PosMed/search\#result. Acesso em 03 de Agosto de 2010.

Richieri-Costa A, Ferrareto I, Masiero D ald da Silva CRM (1987A). Tibial Hemimelia: Report on $37 \mathrm{New}$ Cases, Clinical and Genetics Considerations. Am J Med Genet 27(4): 867-884.

Rozen S, Skaletsky H (2000) Primer3 on the WWW for general users and for biologist programmers. In: Krawetz S, Misener S (eds) Bioinformatics methods and protocols: methods in molecular biology. Humana Press, Totowa, NJ, pp 365-386.

Santos SC, Pardono E, Ferreira da Costa MI, de Melo AN, Graciani Z, de Albuquerque e Souza AC, Lezirovitz K, Thiele-Aguiar RS, Mingroni-Netto RC, Opitz JM, Kok F, Otto PA. (2008). A previously undescribed syndrome combining fibular agenesis/hypoplasia, oligodactylous clubfeet, anonychia/ungual hypoplasia, and other defects. Am J Med Genet A. 146A(24):3126-31.

$\underline{\text { Sato D }}$, Liang D, Wu L, $\underline{\text { Pan Q, }} \underline{\text { Xia K }}, \underline{\text { Dai H}}, \underline{\text { Wang H}}, \underline{\text { Nishimura G, Yoshiura }}$

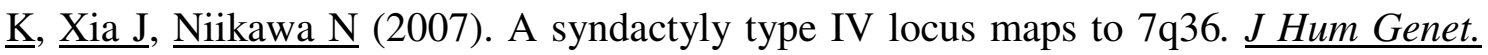
52(6):561-4.

$\underline{\text { Semerci CN}}, \underline{\text { Demirkan F, Ozdemir M}}, \underline{\text { Biskin E, Akin B }}, \underline{\text { Bagci H }}, \underline{\text { Akarsu NA }}$ (2009). Homozygous feature of isolated triphalangeal thumb-preaxial polydactyly 
linked to 7q36: no phenotypic difference between homozygotes and heterozygotes. $\underline{\text { Clin }}$ Genet. 76(1):85-90.

Shibata T, Koide H, Hayashi R, Nagata K, Takeo C, Yoshida T, Noguchi Y, Tanaka T, Saito Y, Tatsuno I (2007). Molecular cloning and characterization of rat brain endothelial cell derived gene-1 (tumor suppressor candidate 5) expressing abundantly in adipose tissues. Mol Cell Endocrinol. Jan 15;263(1-2):38-45.

Stanitski DF, Stanitski CL (2003) Fibular hemimelia: a new classification system. J Pediatr Orthop 23(1): 30-4.

Stevens JD, Roalson EH, Skinner MK (2008). Phylogenetic and expression analysis of the basic helix-loop-helix transcription factor gene family: genomic approach to cellular differentiation. Differentiation. Nov;76(9):1006-22

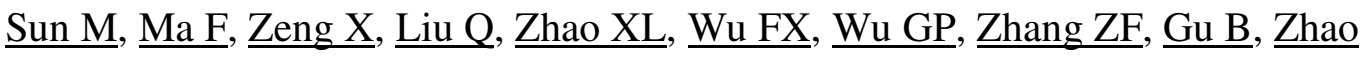

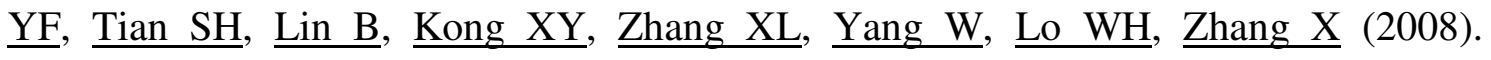
Triphalangeal thumb-polysyndactyly syndrome and syndactyly type IV are caused by genomic duplications involving the long range, limb-specific SHH enhancer. $\underline{J M e d}$ Genet. 45(9):589-95.

Tentamy e McKusick, 1978 apud Nunes ME, Schutt G, Kapur RP, Luthardt F, Kukolich M, Byers P, Evans JP (1995). A second autosomal split hand/split foot locus maps to chromosome 10q24-q25. Hum Mol Genet. 4(11):2165-70.

Ugur SA, Tolun A (2008). Homozygous WNT10b mutation and complex inheritance in Split-Hand/Foot Malformation. Hum Mol Genet. 17(17):2644-53.

Uniscience - Affymetrix GeneChip Mapping 100K Assay Manual URL: htpp:// www.uniscience.com.br/.../1035-human-mapping-10k-20-array.

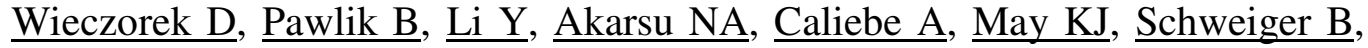
Vargas FR, Balci S, Gillessen-Kaesbach G, Wollnik B (2010). A specific mutation in 
the distant sonic hedgehog $(\mathrm{SHH})$ cis-regulator (ZRS) causes Werner mesomelic syndrome (WMS) while complete ZRS duplications underlie Haas type polysyndactyly and preaxial polydactyly (PPD) with or without triphalangeal thumb. Hum Mutat. 31(1):81-9.

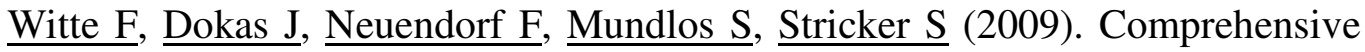
expression analysis of all Wnt genes and their major secreted antagonists during mouse limb development and cartilage differentiation. Gene Expr Patterns. 9(4):215-23.

Woods C G, Stricker S, Seemann P, Stern R, Cox J, Sherridan E, Roberts E, Springell K, Scott S, Karbani G, Sharif SM, Toomes C, Bond J, Kumar D, Al-Gazali L, Mundlos S (2006). Mutations in WNT7A cause a range of limb malformations, including Fuhrmann syndrome and Al-Awadi/Raas-Rothschild/Schinzel phocomelia syndrome.The American Journal of Human Genetics 79: 402-408.

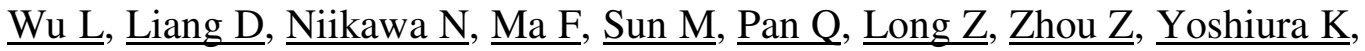
$\underline{\text { Wang H}}$, Sato D, Nishimura G, Dai H, Zhang X, Xia J (2009). A ZRS duplication causes syndactyly type IV with tibial hypoplasia. Am J Med Genet A. 149A(4):816-8.

Yoshinari A, Fumihiko K, Tohru I, Keisuke T, Yasuo T, Miki O, Motoko S, Motohisa T, Hideaki I, Tsuneo I, Takao K, Toshiaki I, Michael BY, Masao O (2010). Identification of a Suppressive Mechanism for Hedgehog Signaling through a Novel Interaction of Gli with 14-3-3. The Journal of Biological Chemistry 285(6): 4185-4194.

Zeller R, Zuniga A (2007). Shh and Gremlin1 chromosomal landscapes in development and disease. Genetics \& Development 17:428-434.

Zhou F, Leder P, Zuniga I, Dettenhofer M (2009). Formin1 disruption confers oligodactylism and alters Bmp signaling. Human Molecular Genetics.18:(13) 24722482.

Zlotogora J (1994). On the inheritance of the split hand/split foot malformation. Am J Med Genet. 53(1):29-32. Review. 